Areal Geology of the

Western Mojave Desert

California

GEOLOGICAL SURVEY PROFESSIONAL PAPER 522

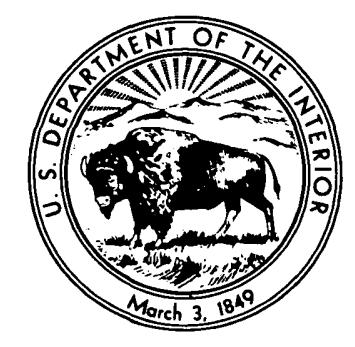




\section{Areal Geology of the}

Western Mojave Desert

California

By THOMAS W. DIBBLEE, JR.

GEOLOGICAL SURVEY PROFESIONAL PAPER 522

Contribution to west coast

earthquake investigations

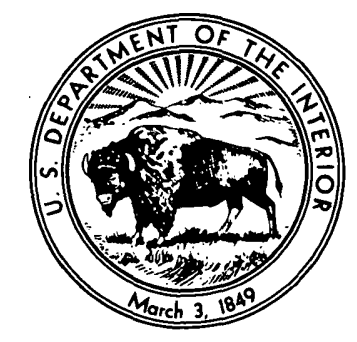

UNITED STATES GOVERNMENT PRINTING OFFICE, WASHINGTON : 1967 


\section{UNITED STATES DEPARTMENT OF THE INTERIOR \\ STEWART L. UDALL, Secretary \\ GEOLOGICAL SURVEY \\ William T. Pecora, Director}

Library of Congress catalog-card No. GS 67-202

For sale by the Superintendent of Documents, U.S. Government Printing Office Washington, D.C. 20402 


\section{AREAL GEOLOGY OF THE WESTERN MOJAVE DESERT CALIFORNIA}




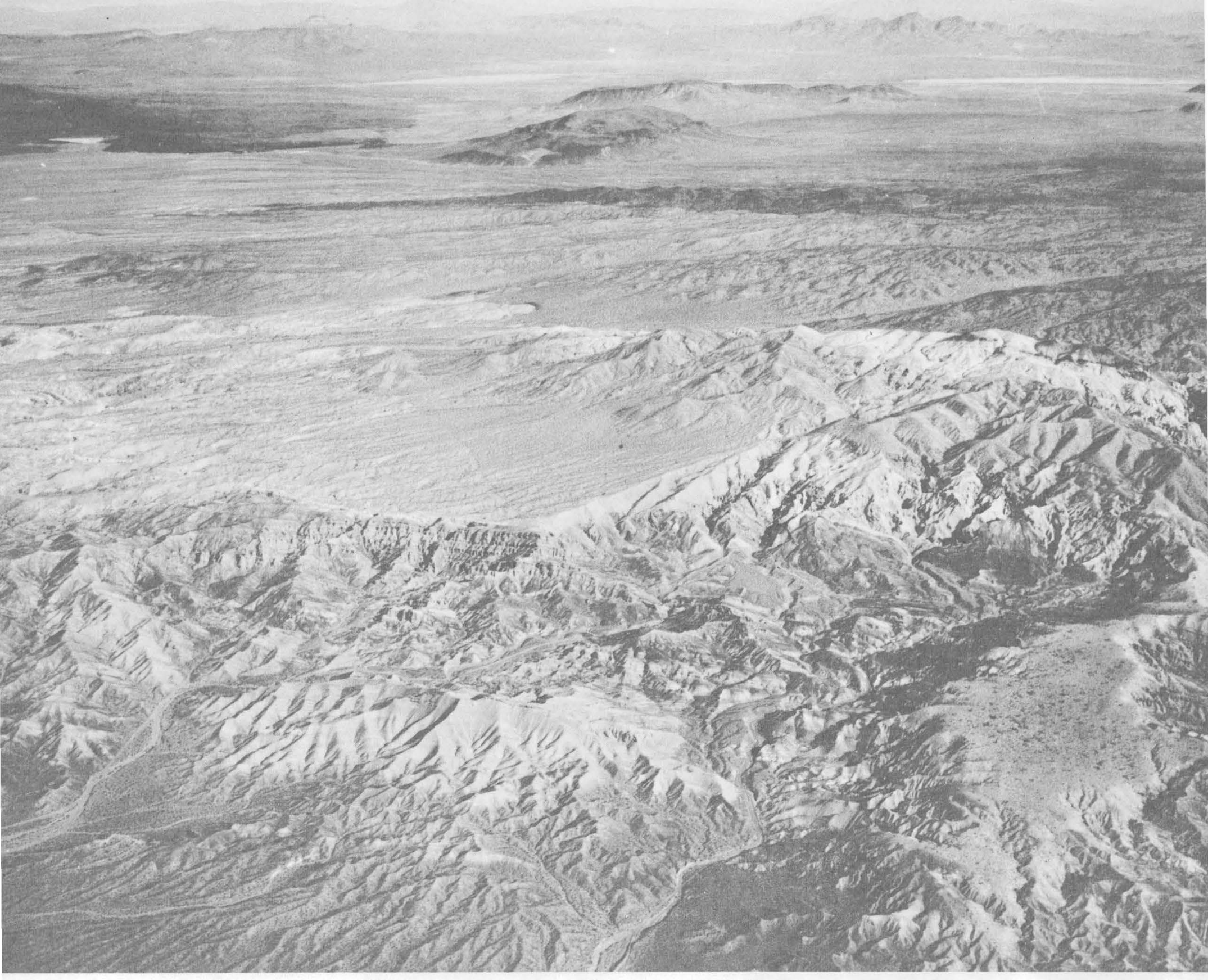

Aerial view looking northwest over the Mud Hills, 9 miles north of Barstow. Fossiliferous terrestrial beds of Miocene Barstow Formation are partly capped by dissected older alluvium. Rainbow Canyon is at lower right. Beds dip into axis of major syncline with axis across amphitheater of Rainbow Canyon. Light-colored hills beyond amphitheater eroded from pyroclastic rocks of lower Miocene(?) Pickhandle Formation. Hills in background are mainly Mesozoic plutonie rocks overlain by Pliocene(?) andesite and Pleistocene basalt. Goldstone dry lake is at upper right. 


\section{CONTENTS}

Abstract

Introduction . . . Location of area Fieldwork and preparation of geologic map...... Purpose of investigation . .

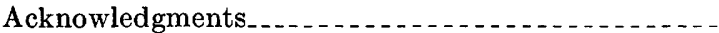

Previous geologic work

Geographic setting

Culture and accessibility

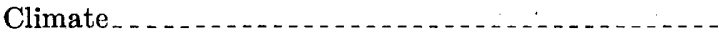

Vegetation

Geologic setting

Pre-Tertiary crystalline rocks $\ldots \ldots \ldots$

Older dynamothermal metamorphic rocks . . . . . . .

Schistose rocks. . . . . . . . . . . . . . . .

Distribution .................................

Pelona Schist.............................

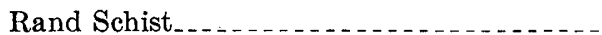

Mesquite Schist .........................

Origin and age

Mylonitic rocks.

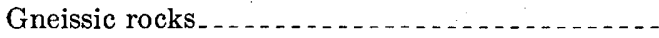

Unnamed gneissic rocks . . . . . . . . . .

Waterman Gneiss.

Origin and age $\ldots$

Metasedimentary rocks.......

Unnamed metasedimentary rocks . . . . . . . . . . Bean Canyon Formation

Oro Grande Formation . . . . . . .

Fairview Valley Formation. . Garlock Formation ..................

Age

Metavolcanic and hypabyssal rocks ............ Hodge Volcanic Formation Porphyry complex . . . . . . . . . . . . . .

Porphyry ..................

Porphyritic felsite

Tourmaline-quartz-muscovite rock . . . . . Field relations, origin, and age............. Quartz latite felsite................................ Rhyolite aplite. Hornblende schist and greenstone

Plutonic rocks.

Hornblende diorite and gabbro..........

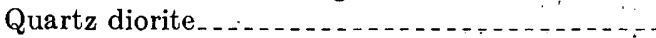
Ferruginous syenite Aplitic quartz monzonite. . . . . Gneissoid quartz monzonite . . . . . . . . . . . Biotite-rich quartz monzonite . . . . . . . . . . . . Granite and quartz monzonite............. Quartz monzonite

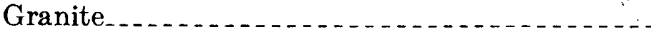
Pegmatite and aplite

Hypabyssal rocks.

Quartz latite

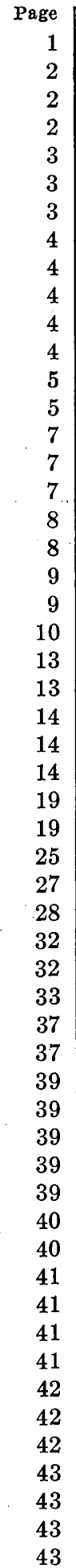

Tertiary sedimentary and volcanic rocks._.......... 43

General features............................. 43

Rock units of southern and western areas......... 44

Palmdale, Valyermo, and Cajon Pass areas..... . 44

San Francisquito Formation ............ 44

Vasquez Formation

Vaqueros Formation: . .

Punchbowl Formation.

Crowder Formation............. 49

Anaverde Formation . . . . .

Peace Valley area.......... 56

Peace Valley Beds of Crowell (1950) _..... 56

Hungry Valley Formation of Crowell

(1950)

West Antelope Valley area..............

Neenach Volcanic Formation..........

Quail Lake Formation

Oso Canyon Formation...............

Meeke Mine Formation . . . . . . . . . . .

Rock units of central areas........................

Antelope Butte, Rosamond, and Mojave areas.

Gem Hill Formation ....................

Bobtail Quartz Latite Member.........

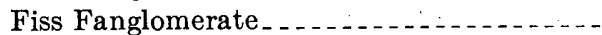

Bissell Formation.........................

Castle Butte, Boron, and Kramer Hills areas..-

Unnamed lower part of Tropico Group _. - -

Dacite

Saddleback Basalt. .....................

Red Buttes Quartz Basalt . . . . . . . . . . .

Unnamed upper part of Tropico Group...-

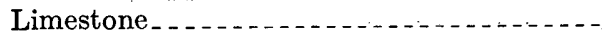

Rock units of eastern areas _............... 82

Barstow area .......................... 82

Unnamed sedimentary rocks . . . . . . . . 82

Dacite............ 83

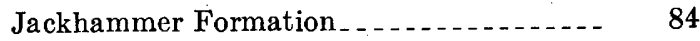

Pickhandle Formation

Opal Mountain Volcanic Formation...... 86

Barstow Formation .......... 86

Lane Mountain Andesite. ............ 91

Rock units of northern areas._............... 91

Tehachapi Valley and Cache Peak areas...... 91

Witnet Formation.

Kinnick Formation

Rhyolitic felsite

Bopesta Formation. . .

Andesite $\ldots$

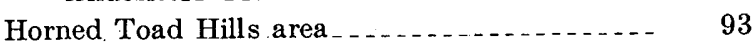

Horned Toad Formation

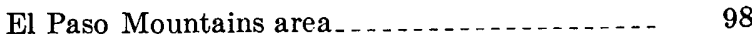

Goler Formation

Dacite................... 98

Ricardo Formation $\ldots$ 
Tertiary sedimentary and volcanic rocks-Continued

Rock units of northern areas-Continued

Lava Mountains area Gray andesite porphyry Rhyolite felsite

Bedrock Spring Formation................ Andesite

Unnamed sandstone and basalt

Quaternary sedimentary deposits and basalt Older alluvium Black Mountain Basalt Alluvium . . . . . . . . . . Windblown sand......... Playa clay

Geologic structure Tertiary depositional basins . .

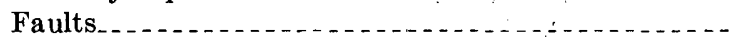
Present tectonic activity Summary of geologic history
Mineral resources Mineral deposits and rock commodities............ Deposits and possible occurrences of borate minerals. Discovery and mining of borate minerals.... Geology of known borate deposits. ......... Probable genesis. Reserves.

Possible occurrences of other borate deposits and areas favorable to prospect

Petroleum and gas.

Ground water.

Movement of ground water. . . . . . . . 129

Effect of faults on ground-water movement _. . 129

Ground water in pre-Tertiary rocks . . . . . . . . 129

Ground water in Tertiary rocks............. 130

Ground water in Quaternary sediments....... 130

Ground-water reservoirs . . . . . . . . . . . . . 130

Magmatic water..... 130

References cited ............ 130

\section{ILLUSTRATIONS}

[Plates are in pocket]

Plate 1. Geologic map of western Mojave Desert, California.

2. Map of western Mojave Desert region, showing major physiographic and geographic features.

3. Index map showing location of detailed geologic maps and sections, figures $3-69$, and explanation of symbols.

4. Sequences of sedimentary and volcanic rocks of Cenozoic age exposed in western Mojave Desert.

Frontispiece. Aerial view looking northwest over the Mud Hills, 9 miles north of Barstow.

FIGURE 1. Index map of southeastern California showing location of western Mojave Desert region -

2. Diagrammatic section of generalized rock units.

3-69. Detailed geologic maps and sections of critical areas:

3, 4. Rand Mountains

10,12

5, 6. Hills north of Barstow

15,16

7, 8. Iron Mountain area_......... 17, 18

9. Hills north of Hinkley

10. Hills west of Harper Valley .....

11. Bronco and Antelope Canyon area, Tehachapi Mountains...

12, 13. Techachapi Mountain foothills _- 22, 24

14, 15. Quartzite Mountain area_... _. 26, 27

16, 17. Shadow Mountains........... 29, 30

18. Northernmost part of Sidewinder Mountain
Figure 19. Juniper Flat area, northwestern San Bernardino Mountains..........................

20. Black Mountain area near Sidewinder Mountain .

21, 22. Central and eastern El Paso Mountains $34-35$

23. Stoddard well area

24. Hills southwest of Mirage Lake.......... 40

25. Saddleback Butte area east of Lancaster .... 44

26. San Francisquito Canyon area . . . ....... 45

27. Soledad Pass area . . . . .

28. Little Rock area

29, 30. Devils Punchbowl area _........ _. 50,51

31, 32. Cajon Pass area, northwestern part _... _ 52-53, 54

33. San Gabriel Mountain foothill area near Mescal Creek....................... 55

34. Palmdale area

35-37. West end of Antelope Valley _... _. _ _ _ 59, 60, 61

38. Antelope Buttes area............... 64

39, 40. Rosamond Hills. . .

41. Middle Buttes ........ 67

42. Soledad Mountain area

43. Bissell Hills area . . . .

44, 45. Castle Butte area._...

46, 47. Kramer borate district. . . . . . . . . . . . 74, 75

48. Muroc and Stone House Hills. . ......... 77

49. Kramer Junction or east Kramer area.... 78

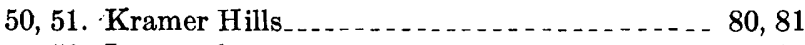

52. Lenwood area........... 83

53. Upper Black Canyon and Opal Mountain

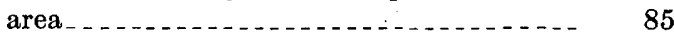

54, 55. Mud Hills

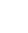

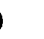

0

.


Figure 56. Northwestern and central Gravel Hills......

57. Southeastern Gravel Hills and lower Black

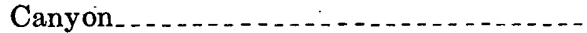

58. Monolith-Sand Creek area, southern Sierra Nevada............................

59. Cache Peak area, southern Sierra Nevada

60. Monolith and Cache Peak areas, southern Sierra Nevada..........................

61. Jawbone Canyon area, southern Sierra Nevada...................................

62. Horned Toad Hills area ...............

63. Lower Jawbone and Redrock Canyons area, El Paso Mountains . . . . . . . . . .

64-66. Last Chance Canyon, Black Mountains-Goler Gulch, and Redrock Canyon areas, El Paso Mountains................... 102, 103, 104

67. Red Mountain area.......... 106

68. Summit Diggings area_. . . . 107

69. Sand Hills.

70. Bouger anomaly and generalized geologic

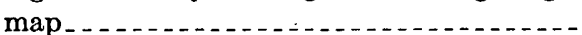

Page

90

92

94

95

96

97

99

101

110
Figure 71. Probable areal extent of depositional basins filled with sedimentary and volcanic rocks of Tertiary age and their inferred profiles and depths.

72. Simplified geologic map of San Andreas fault zone at margin of Mojave Desert, showing evidence suggesting right lateral displacements, measurable in miles, on San Andreas fault and its branches.....

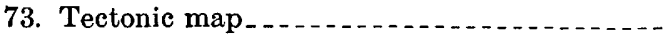

74-80. Paleogeographic maps-Tertiary through Pleistocene time.

74. Paleocene and Eocene........

75. Oligocene(?), early, and early middle Miocene............. 118

76. Late middle and late Miocene _.. $\quad 119$

77. Pliocene. . . .

78. Beginning of Pleistocene $\ldots . .121$

79. Pleistocene

80. End of Pleistocene

\section{TABLES}

[Tables 2-4 follow "References cited"]

TABLE 1. Divisions of Tropico Group in western Mojave Desert and their presumed correlations...-

2. Tabulated list of borate mines.
Page 63 137
TABLE 3. Exploratory test holes drilled for minerals.... 4. Exploratory test wells (drilled for oil and gas) and geological significant water wells.
Page

138

148 


\title{
AREAL GEOLOGY OF THE WESTERN MOJAVE DESERT, GALIFORNIA
}

\author{
By Thomas W. Dibblee, Jr.
}

\begin{abstract}
The western Mojave Desert is in Kern, Los Angeles, and San Bernardino Counties. In this 7,000-square-mile region are the towns of Gorman, Palmdale, Lancaster, Rosamond, Mojave, Randsburg, Boron, Barstow, and Victorville. The center of the region is about 70 miles north-northeast of Los Angeles.

The western Mojave is a wedge-shaped area, bordered on the southwest and northwest by rugged mountain ranges that reach altitudes of 10,080 and 7,900 feet above sea level, respectively. The desert itself has comparatively low relief, and is virtually an alluviated plain containing irregularly trending bedrock hills and low mountains. The alluvial area contains seven undrained dry lakes or playas in the lowest parts. The only through-going drainage channel is that of the Mojave Riveran intermittent river that flows from the lofty San Bernardino Mountains northward, and then eastivard, out of the mapped area.
\end{abstract}

The alluviated desert plain ranges from altitudes of about 4,000 feet adjacent to the bordering mountains to about 2,000 feet at the playa flats and along the Mojave River channel. The bedrock areas within the desert region rise to generally not more than 1,500 feet above the surrounding alluviated flats, although the highest peak rises to about 2,400 feet above them, or to an altitude of about 5,200 feet above sea level.

The rocks of the western Mojave Desert region and the bordering mountains may be grouped into three main divisions: (1) crystalline rocks of pre-Tertiary age; (2) sedimentary and volcanic rocks of Tertiary age; and (3) sediments and local basalt flows of Quaternary age.

The crystalline rocks are largely plutonic, and there are some isolated pendants of metamorphic rock. The crystalline rocks may be grouped into four major divisions: (1) older dynamothermal metamorphic rocks; (2) metasedimentary rocks; (3) hypabyssal and metavolcanic rocks; and (4) plutonic rocks.

The older dynamothermal metamorphic rocks are divided into three units: schistose rocks, mylonitic rocks, and gneissic rocks. They are unfossiliferous and presumably are of Precambrian age.

The metasedimentary rocks are assemblages of carbonate rocks, phyllites, schists, cherts, quartzites, and conglomerates of marine origin, and minor mafic to andesitic flows. Meager fossils found in a few assemblages indicate late Paleozoic age.

The hypabyssal and metavolcanic rocks are porphyritic and aphanitic intrusives and extrusives of mainly Mesozoic age in the eastern part of the desert region.

The plutonic rocks are granitic-textured intrusives that range in composition from hornblende diorite and gabbro through quartz diorite and quartz monzonite to granite. Quartz monzonite is by far the most prevalent type; it forms the southeast extension of the Sierra Nevada batholith through the west- ern Mojave Desert. Lead-alpha age determinations indicate a range from 90 to 96 million years, or Cretaceous age, for this rock.

The sedimentary and volcanic rocks of Tertiary age include conglomerates, sandstones, shales, carbonates, tuffs, breccias, and lava flows and plugs ranging in composition from rhyolite to basalt. These rocks rest upon a deeply eroded surface of the crystalline rocks from which the clastic rocks were largely derived. Rapid lateral changes in lithology and thickness of stratigraphic assemblages of the Tertiary rocks indicate deposition during tectonic activity.

The oldest Tertiary stratigraphic units are clastic sedimentary rocks of early Tertiary age and are known only in the mountains that border the desert region. Terrestrial units of Oligocene to middle Miocene age are mainly volcanic rocks of rhyolitic to andesitic composition, in large part pyroclastic, and minor sedimentary rocks and mafic flows. Units of late Miocene age are nearly all sedimentary, except for some andesitic intrusions and flows in the northwest-bordering mountains. With the exception of a marine and brackish-water formation at the west end of the desert region, all the sedimentary units in the desert are nonmarine and range from coarse stream-laid sediments to lacustrine shales and minor chemical sediments. Units of Pliocene age are all nonmarine; they are sedimentary in southern parts of the mapped area, sedimentary and volcanic in northern parts. Nearly all units include both stream-laid and lacustrine strata.

The sediments of Quaternary age are mainly alluvial deposits that fill the major part of the desert region. They range from coarse fanglomerate to fine clay derived from the mountains that border the desert region and from the highlands within it. In most places these sediments rest unconformably on rocks of Tertiary and pre-Tertiary ages, but in some places are conformable on Tertiary sedimentary rocks.

The structure of the metamorphic rocks within the mapped area is complex; prior to the invasion of the plutonic rocks they were severely folded, upturned, and in places thrust faulted. In the desert region, structural trends in these rocks are erratic, but are predominantly west to northwest in the northwestbordering mountains, mostly west in the southwest-bordering mountains.

The western Mojave Desert region is a tectonic block-known as the Mojave block-bounded on the southwest by the San Andreas fault zone and on the northwest by the Garlock fault zone, along which the bordering mountains were elevated. Both zones are vertical crustal breaks along which major displacements are strike slip or lateral. Total cumulative right-lateral movement on the San Andreas fault zone in this region may be about 50 miles, and left-lateral movement on the Garlock fault zone about 17 miles, possibly as much as 30 . 
The Mojave block is also broken by several major high-angle faults, most if not all active during Quaternary time. They generally trend northwest, form low scarps if any at all, are characterized by reversals of (apparent) vertical displacements, and show evidence in several places of small right-lateral displacements. Some faults trend northeast; most of these are north-dipping normal faults:

Tertiary formations exposed throughout the area are strongly deformed, either by tilt or by compression into folds having west-trending axes. They are most severely deformed adjacent to the major faults that have lateral displacement. Quaternary formations are deformed in the same manner but to less degree.

Alluvium-covered parts of the Mojave block are underlain by several large basins or downwarps that contain as much as 10,000 feet of Cenozoic sedimentary fill. The Cenozoic formations are presumably undeformed in the central parts of most of these basins,

The major domestic source of boron compounds is a single large deposit of sodium borate near the town of Boron. This deposit is in lacustrine shale of the upper (middle Miocene) part of the Tropico Group. The lacustrine shale is practically devoid of other saline minerals. The source of the borate minerals is presumably volcanic thermal springs genetically related to basalt flows that underlie the shale. The small marginal and outlying deposits are mostly of calcinm borate.

\section{INTRODUCTION}

LOCATION OF AREA

The Mojave Desert in southeastern California is a wedge-shaped region having its apex toward the west. This report deals with the western part of the deserta part that is characterized by interior drainage and is sharply delineated by mountain ranges on both the southwest and northwest. The part mapped geologically includes about 7,200 square miles between latitudes $34^{\circ} 34^{\prime}$ and $35^{\circ} 30^{\prime} \mathrm{N}$. and longitudes $117^{\circ}$ and $119^{\circ}$ W., or parts of Kern, Los Angeles, and San Bernardino Counties. The center of the region lies about 70 miles airline north-northeast of Los Angeles (fig. 1).

\section{FIELDWORK AND PREPARATION OF GEOLOGIC MAP}

Fieldwork was done during the spring, autumn, and winter months from 1952 to 1955 and during short intervals from 1956 to 1959.

The geology was plotted in the field on aerial photographs at scales between about $1: 48,000$ and $1: 25,000$,

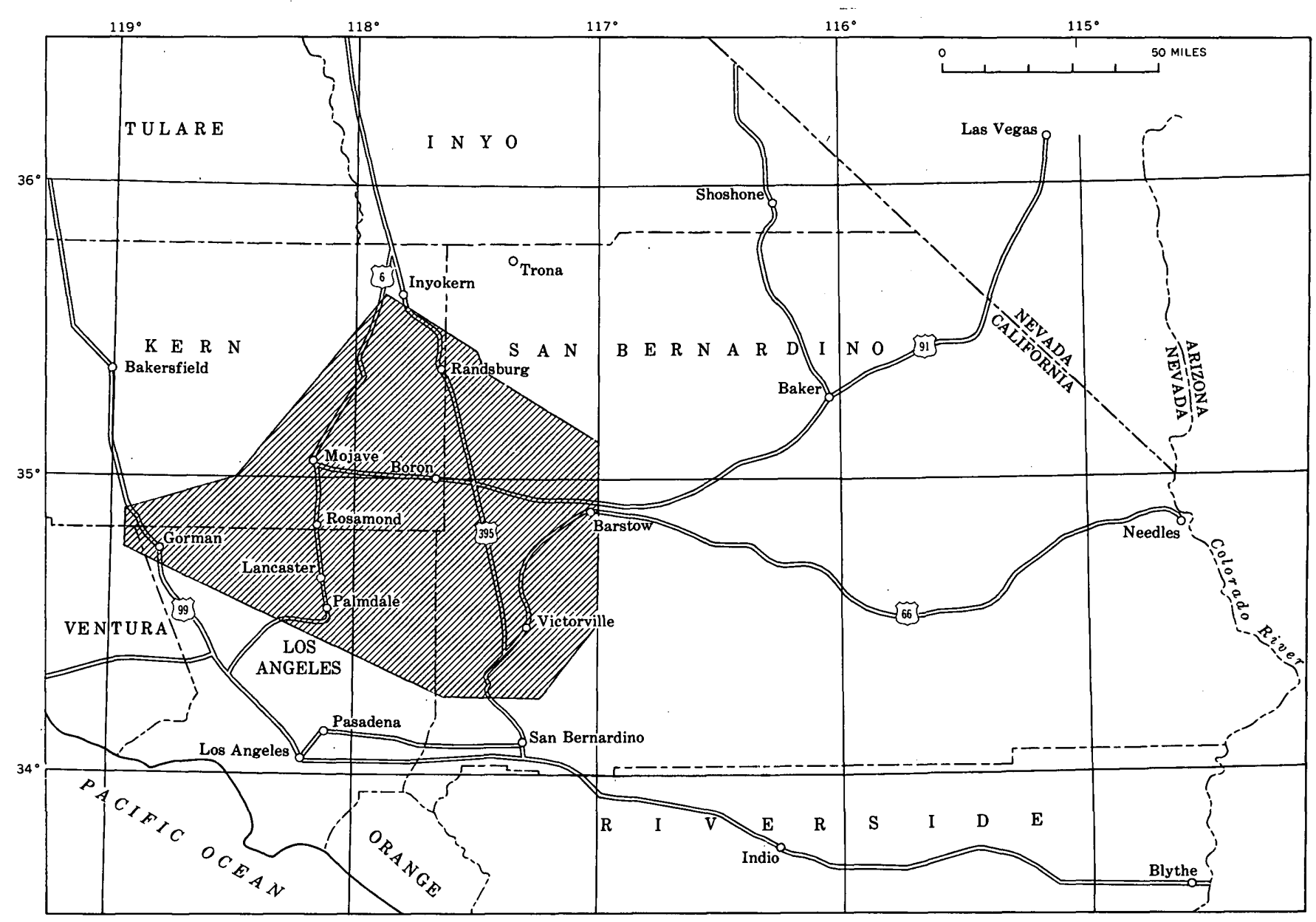

Figure 1.-Index map of southeastern California showing location of western Mojave Desert region. 
and was subsequently transferred to 15 -minute $1: 62$,500 -scale topographic quadrangle base maps as these became available. An average of about 1 month was required to map the geology of each quadrangle and about another month was required to transfer the geology from aerial photographs to the quadrangle base map. Geologic maps of fifteen 15-minute quadrangles (pl. 1, index to topographic maps) were published prior to completion of this report (Dibblee, 1958a, b; 1959a, b; 1960a-g; 1961b; 1963). Published maps of areas studied by other geologists (pl. 1, index to geologic maps) were field checked and, where necessary, were remapped by the writer before incorporation in this report. All data were recompiled at a scale of $1: 125,000$ (pl. 1).

\section{PURPOSE OF INVESTIGATION}

This report and map (pl. 1) represent part of a geologic investigation by the U.S. Geological Survey of the known and potential deposits of borate minerals in the southern California desert regions. The primary purpose of this report and the geologic map (pl. 1) is to provide a geologic background for the exploration for possible concealed borate deposits in the western Mojave Desert, based upon (1) the geology of the known deposits of these minerals within the region, (2) the areal geology of the region, and (3) the subsurface geology as determined insofar as possible from logs of exploratory test holes, mine workings, and geophysical data. Available logs of test holes so used, including those drilled for petroleum and some for water, and of borate mine shafts are summarized in tabulated form (tables 2-4); the gravity geophysical data are published separately (Mabey, 1960).

The resulting geologic data are of use for many secondary purposes, such as exploration for other commodities, including petroleum and gas, and in evaluation of ground-water conditions.

The base for the geologic map was prepared by joining parts of the Bakersfield, Trona, Los Angeles, and San Bernardino quadrangles, as published by the U.S. Geological Survey at a scale of $1: 250,000$, and then enlarging the mosaicked map to a scale of $1: 125,000$ (1 inch $=2$ miles). Although lacking in detail and accuracy, the base is the best that is available. Numerous maps at a scale of an inch to a mile or larger show the geology of most of the complex areas in greater detail.

\section{ACKNOWLEDGMENTS}

The writer is particularly indebted to the following members of the U.S. Geological Survey:D. F. Hewett for his unfailing interest in the work and for the aerial photographs used in mapping, W. C. Smith for his technical advice and direction, K. E. Lohman, for work on fossil diatoms in the area; G. E. Lewis, for work on the vertebrate fossils from the Mud Hills and Black Canyon, and R. D. Allen for modal analyses of the igneous rocks.

Mr. D. J. Ryan, geologist for Kerr-McGee Oil Industries, Mr. R. G. Maynard, geologist for SunrayMid-Continent Oil Co., Mr. K. M. Reim, geologist for Kern County Land Co., and Mr. S. J. Muessig, geologist for United States Borax and Chemical Co. (since 1957), have furnished logs of many prospect holes drilled for borates in the region.

The investigation was supported in part by funds from the Bureau of Aeronautics, U.S. Navy.

\section{PREVIOUS GEOLOGIC WORK}

The earliest descriptions of the geology of the western Mojave Desert and the mountains along its southwestern margin are by Hershey $(1902 a, b)$. In his first report he described the pre-Tertiary crystalline rocks; in his second, the Tertiary sedimentary and volcanic rocks. He discussed probable correlations, named several formations, and prepared a geologic sketch map.

The Tertiary rocks were further described by Baker (1911, 1912), and their fossils were described in several papers by Merriam (1911, 1914, 1915, 1919).

Pack (1914b) did a reconnaissance and discussed the oil possibilities of the Harper Valley area between Barstow and Kramer. $\mathrm{He}$ also presented a geologic map-the first in the western Mojave Desert.

Darton (in Darton and others, 1915) described the rocks of the Barstow-Victorville area.

The ground-water resources of Antelope Valley were described by Johnson (1911). This report was followed some years later by an exhaustive study by Thompson (1929) of the ground-water conditions of the entire Mojave Desert; Thompson's report includes a reconnaissance geologic map of the desert region.

Hulin (1925) described the geology and ore deposits of the Randsburg 15-minute quadrangle in a report which included a 1:62,500-scale quadrangle geologic map-the first one in the Mojave Desert. Similar reports and geologic maps of other quadrangles and areas within the western Mojave Desert followed. Among these were reports by Simpson (1934) on the Elizabeth Lake (30-minute) quadrangle; Gardner (1940) on the Newberry and Ord Mountains; Gale (1946) on the Kramer borate district; Wallace (1949) on the San Andreas fault zone west of Palmdale; Crowell (1950 and 1952) on the Gorman-Hungry Valley area, and on the Lebec (71/2-minute) quadrangle; Wiese (1950) on the Neenach quadrangle; 
Dibblee (1952) and Dibblee and Gay (1952) on the Saltdale quadrangle; Noble (1953 and 1954a) on the Pearland and Valyermo (6-minute) quadrangles; Bowen (1954) on the Barstow (30-minute) quadrangle; Troxel (1954) on the northwestern Shadow Mountains; and Dibblee (1967) on the Fremont Peak and Opal Mountain quadrangles. The locations of these published geologic maps are shown on the index map on plate 1 .

In addition, several reports and generalized geologic maps of parts or all of the western Mojave Desert have been published by Miller (1944) on the geology of the Barstow, Hinkley, and Oro Grande areas; Wiese and Fine (1950) on the geology of west Antelope Valley; Hewett (1954a and 1954b) on the general geology of the Mojave Desert and on the faults of the Mojave Desert; Buwalda (1954) on the geology of the Tehachapi Mountains; and Noble (1954b) on the geology of the San Andreas fault area between Caion Pass and Soledad Pass. The locations of most of these areas are also shown on the index map on plate 1 .

\section{GEOGRAPHIC SETTING}

\section{CULTURE AND ACCESSIBILITY}

Except in scattered towns (pl. 1), the western Mojave Desert region is virtually uninhabited. The largest towns in the area, according to the 1960 census, are Barstow, with about 10,000 inhabitants; Victorville, with about 8,000 ; Lancaster, with about 25,000 ; Palmdale, with about 10,000; and Edwards, with about 5,000 .

The area is traversed by several major highways, and many paved, gravel, and dirt roads; these make all parts of the region accessible by road. The region is also traversed by several lines of the Southern Pacific Railroad and the Atchison, Topeka, and Santa Fe Railway. Several military installations prohibit or restrict travel locally.

The principal physiographic and geographic features of the western Mojave Desert are shown on plate 2 .

\section{CLIMATE}

The Mojave Desert is characterized by arid climate and a wide range of seasonal and daily temperatures. Maximum summer temperatures commonly exceed $100^{\circ} \mathrm{F}$. Minimum winter temperatures fall below freezing, sometimes to $5^{\circ} \mathrm{F}$. Diurnal temperature changes commonly exceed $50^{\circ} \mathrm{F}$ throughout the year.

Average annual precipitation ranges from less than 5 inches in the interior parts to more than 40 inches on the crest of the San Gabriel Mountains. Most precipitation comes from Pacific cyclonic storms that pass eastward over the region from November to April.
Generally the storms bring rain or snow in the mountains, but only a few bring rain to the desert because of the drying effect of the bordering mountains on the moisture-laden air descending their leeward slopes. Nearly all storms are accompanied or followed by gales that blow over the Tehachapi and Sierra Pelona Mountains and eastward across the desert region, commonly with enough force to carry dust and sand in the desert.

Occasionally during the late summer months thunderstorms bring heavy showers or cloudbursts. These storms result in flash floods and cause severe erosion locally.

\section{VEGETATION}

Vegetation in the desert region is of the sagebrush type and consists of scattered but evenly spaced plants, mostly creosote bush and burro bush. Grasses and flowering annuals grow only in spring after unusually heavy winter rains. The vegetation is generally uniform, the underlying rock formations having little influence upon it. Giant yuccas (Joshua trees) are common on sandy flats and alluvial slopes between altitudes of 2,800 and 4,000 feet. Cottonwoods and some willows grow along the permanent streams. The playa-lake beds are devoid of vegetation.

Mountain slopes facing the desert between altitudes of 4,000 and 6,000 feet are partly covered with chaparral consisting mainly of scrub oak, chamiso, manzanita, juniper, piñon pine, and yucca. Above 6,000 feet the mountains are forested with oak, sugar pine, and some cedar.

\section{GEOLOGIC SETTING}

The Mojave Desert region is geologically a great wedge-shaped fault block, called by Hewett (1954a, p. $16-17,1954 \mathrm{~b}$, p. 5) the "Mojave block." It is bounded by the San Andreas and Garlock fault zones on the southwest and north, respectively, but has no definite natural eastern limits. Both fault zones are continuous, generally vertical, crustal breaks having lateral displacements measurable in miles. Of these two master shear zones, the San Andreas fault zone is by far the larger, having a known length of at least 600 miles and a possible cumulative right-lateral displacement of as much as 350 miles (Hill and Dibblee, 1953 , p. 449). The mountain ranges elevated along the San Andreas fault zone separate the Mojave Desert from the coastal area to the southwest.

The Garlock fault zone, though subordinate to the San Andreas fault zone in length and magnitude of displacement, is nevertheless a master shear zone that is traceable for some $\mathbf{1 5 0}$ miles and has a left-lateral displacement of unknown magnitude. This fault separates the Mojave block from the Sierra Nevada- 
Tehachapi Mountain uplift and the Basin and Range province to the north.

The Mojave block itself is broken by many major but discontinuous faults, as shown on plate 1. These appear to be generally vertical to steep shear zones having predominantly lateral displacements of relatively small amounts. In the mapped area (pl. 1), these faults trend northwest, and displacements on some are right lateral, as on the San Andreas. However, in the northeastern part of the Mojave block, the faults trend predominantly east; some show evidence suggestive of left-lateral displacement. Many of the faults bound or partly bound desert mountain ranges and valleys; others transect them. (For a map showing the geologic setting of the western Mojave Desert, see Dibblee, 1960d, pl. 7, or 1963, pl. 11.)

In the western Mojave Desert region and adjacent mountains, the rocks may be grouped into the following three main divisions: (1) crystalline rocks of preTertiary age, (2) sedimentary and volcanic rocks of Tertiary age, and (3) sediments and local basalt flows of Quaternary age. A generalized section of the rock units of the western Mojave Desert is shown diagrammatically on figure 2.

The pre-Tertiary crystalline rocks may be grouped into the following four major divisions based largely upon their lithologic characteristics: (1) older dynamothermal metamorphic rocks, (2) metasedimentary rocks, (3) hypabyssal and metavolcanic rocks, and (4) plutonic rocks. Of these major rock units the plutonic rocks are by far the most extensive, in which the older metamorphic and the metasedimentary rocks occur as isolated roof pendants.

The older dynamothermal metamorphic rocks are schists, mylonites, and gneisses; they are unfossiliferous and presumably of Precambrian age. The metasedimentary rocks are assemblages of carbonates, phyllites, schists, cherts, quartzites, and conglomerates of marine origin. Meager fossil remains indicate late Paleozoic ages. The hypabyssal and metavolcanic rocks are porphyritic and aphanitic intrusives and extrusives associated with the metasedimentary and plutonic rocks, and they range in age from Paleozoic to early Tertiary, but are mainly Mesozoic. The plutonic rocks are widespread granitoid-textured (hypautomorphic) intrusives ranging in composition from granite to gabbro, but are predominantly quartz monzonite; they are mainly if not entirely of Mesozoic age.

The sedimentary and volcanic rocks of Tertiary age are predominantly of terrestrial origin and include conglomerates, sandstones, shales, carbonate rocks, silicic tuffs and breccias, and lava flows and plugs ranging in composition from rhyolite to basalt. Stratified assemblages of these rocks are characterized by rapid lateral changes in lithology and thickness that indicate deposition in local intermontane basins during times of tectonic activity.

The sediments of Quaternary age consist mainly of alluvial deposits that fill the intermontane areas of the Mojave block and the small valleys in the adjacent mountains. The deposits range from a few feet to several hundred or possibly several thousand feet in thickness. The sediments were derived from the adjacent mountains and hills and vary from coarse fanglomerates to fine clays. In most places they rest unconformably on rocks of pre-Tertiary or Tertiary age; in a few places they appear to grade downward into the Tertiary rocks. The Quaternary deposits are divided into (1) older alluvium of Pleistocene age, which is locally tilted, deformed, and dissected; (2) dissected terrace deposits of late Pleistocene age that occur locally; and (3) younger undissected alluvium of Recent age that fills all modern valleys and covers the flood plains. In the northeastern part of the region, the older alluvium contains at least two local basalt flows that range from a few feet to as much as 300 feet in thickness.

The rock units that occur in the area are described in the following pages. Units of the pre-Tertiary crystalline rocks and the Quaternary sediments and basalt are generally widespread and are described in chronologic order from oldest to youngest. However, because units of the Tertiary volcanic and sedimentary rocks are of limited areal extent and of uncertain correlation, local sequences as indicated on plate 1 are described separately.

To conserve both time and space, descriptions of the units have been written in telegraphic style.

Accompanying the description of each rock unit or local sequence is a geologic map of a critical area at a scale of 1 inch to the mile or larger, with one or more cross sections, to show lithologic and structural detail not shown on plate 1 . The positions of these largescale maps of small areas are indicated on plate 3 , together with the symbols used on the maps. The rock sequences exposed in some of these critical areas are shown on plate 4 .

\section{PRE-TERTIARY CRYSTALLINE ROCKS}

\section{OLDER DYNAMOTHERMAI METAMORPHIC ROCKS}

A large part of the pre-Tertiary crystalline complex of the western Mojave Desert region is made up of intensely metamorphosed rocks composed of gneiss, schist, and some mylonite. These rocks crop out mostly in the mountains along the southwestern and north- 


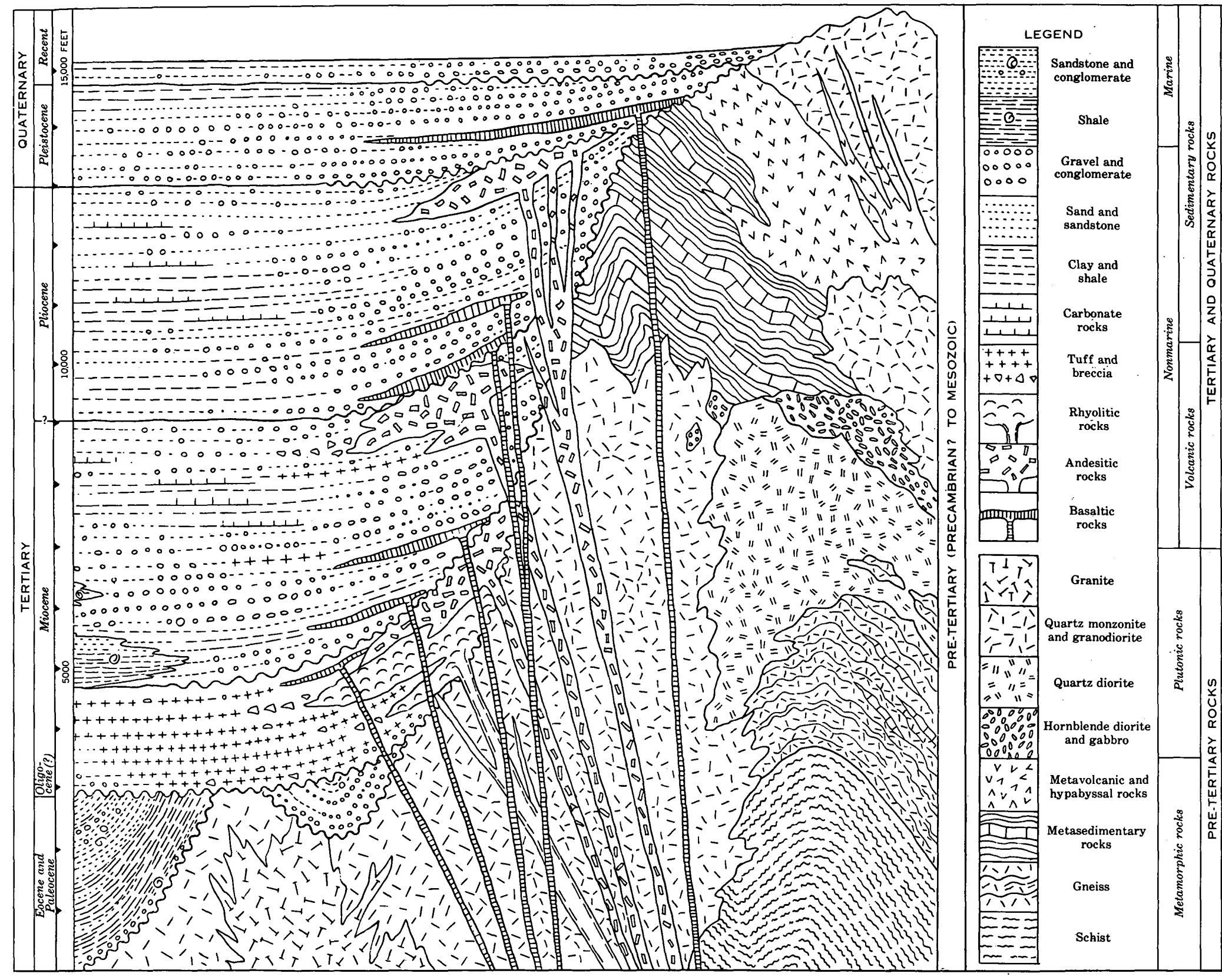

Figure 2.-Diagrammatic section of generalized rock units of western Mojave Desert 
western borders and locally in the eastern and northern parts of the desert.

Because the age relationship of the older metamorphic rocks is controversial, these rocks are described in the order of their present physical positions, which in ascending order is: (1) schistose rocks, (2) mylonitic rocks, and (3) gneissic rocks.

\section{SCHISTOSE ROCKS} DISTRIBUTION

Schist known by local names but here referred to collectively as one major unit under the term "schistose rocks." Exposed south of San Andreas fault in eastern San Gabriel Mountains and Sierra Pelona, and north of it at Portal Ridge; also along or near Garlock fault zone in Tehachapi, El Paso, and Rand Mountains (pl. 1). Rocks are described below under their local names for each area after a general overall description of their lithology.

Schistose rocks dark-bluish to greenish gray; weather gray, yellowish gray, or brown; fine to medium grained; rich in mica or other flaky minerals having parallel orientation; highly foliated, silvery sheen on foliation planes. Foliation parallel to bedding generally, as indicated by color and compositional variations of schist layers and by thin layers of marble and quartzite parallel to foliation of schist. In few places, however, foliation passes through contorted bedding where seen.

Schistose rocks composed of several varieties. Highly foliated gray schist essentially of muscovite, plagioclase, and quartz most widespread; plagioclase (generally albite, rarely oligoclase) scattered as subhedral and anhedral white porphyroblasts, $1 / 2-2 \mathrm{~mm}$ in size, gives schist granular appearance, forms 10-75 percent of the rock, averages about 30 percent; colorless muscovite in small flakes less than 1-mm average diameter, parallel and subparallel with foliation, bent around porphyroblasts of plagioclase, forms $10-25$ percent of rock; flakes of golden-brown biotite and brownish-green chlorite commonly associated with muscovite; quartz forms minute grains generally concentrated in small lenticular patches or layers 1-2 mm thick along foliation planes, forms 10-30 percent of the rock.

As proportion of biotite or chlorite increases, gray muscovite-albite schist grades into dark-lead-gray biotite-albite schist and dark-greenish-gray chlorite schist, respectively; highly foliated.

Chlorite-bearing gray schist grades into green schist composed essentially of chlorite, amphibole (actinolite, some green hornblende), and plagioclase (albite, rarely oligoclase), in varying proportions, and small percentages of epidote (clinozoisite, allanite), magnetite, limonite, and pyrite; most of plagioclase forms augenlike porphyroblasts generally $2-3 \mathrm{~mm}$ locally as large as $5 \mathrm{~mm}$ in diameter, set in a dark-greenish fine-grained groundmass formed by other minerals. Green schist well foliated to "knotty" with crude lineation.

Actinolite schist commonly associated with green schist as lenses or iregular masses few feet or tens of feet wide; composed of apple-green fibrous aggregate of actinolite, in places with veinlike deposits of epidote and quartz; in places altered to talc schist.

In some exposures, marble and quartzite occur as thin layers from few inches to several feet thick intercalated in gray schist parallel to foliation; in zones as thick as 150 feet and as long as several hundred feet. Marble, bedded, white to light-blue gray, fine grained, calcitic; in places contains dark-gray graphitic laminae. Quartzite, gray white to pinkish gray, some stained brown or black from manganese oxides, very fine grained, commonly micaceous.

White quartz present in nearly all exposures of schistose rocks as scattered lenticular veins few inches or feet thick and few feet or tens of feet long; many veins parallel to, others discordant to, foliation of enclosing schist, rarely if ever contain minerals of economic value.

\section{PELONA SCHIST}

Pelona Schist of Sierra Pelona.-Schistose rocks of Sierra Pelona first examined and described in 1853 by Blake (1857, p. 59-60), later described as Pelona schist series by Hershey (1902a, p. 274-277); areal extent and geologic structure first mapped by Simpson (1934, pl. $5)$; section exposed in Bouquet Canyon area, mapped and described in more detail by Muehlberger (1958) and Muehlberger and Hill (1958); also mapped by writer (Dibblee, 1960c, 1961b).

Pelona Schist of Sierra Pelona folded into a double anticline as indicated by foliation attitudes (pl. 1), which exposes about 7,500 feet of schist; base unexposed. Sequence mainly gray schist; contains lesser amounts of intercalated green schist that becomes increasingly abundant downward and predominates in lowest part. Small occurrences of actinolite schist and talc schist locally; few thin layers of marble and quartzite in middle and upper parts. On south flank, top of schist separated by few tens of feet of cataclastic and mylonitic rocks from aplitic quartz monzonite that contains inclusions of gneiss.

Pelona Schist of Portal Ridge.-Schist of Portal Ridge first described by Johnson (1911, p. 23-24); included in Pelona Schist by Simpson (1934, pl. 5) and Wallace $(1949$, pl. 1, p. 781-808).

Crops out in a narrow strip between the San Andreas fault and the Hitchbrook fault to the north. Schist dips north as indicated by foliation attitudes; 
about 6,000 feet of schist exposed. Differs from schist of Sierra Pelona in being darker and having biotite rather than muscovite as predominant mica.

Schist gray; composed essentially of biotite, plagioclase (albite), and quartz. Some contains muscovite, chlorite, epidote (clinozoisite, pistacite), amphibole (actinolite, green hornblende). Sequence texturally uniform; biotite most abundant in lower part, albite in upper part. Schist contains several thin lenses of micaceous quartzite stained brown by oxides of iron and manganese; several diabase dikes in sec. 13, T. 6 N., R. 13 W.

Pelona(?) Schist of Quartz Hill.-Schist at Quartz Hill (about 5 miles southwest of Lancaster) included in Pelona by Simpson $(1934$, p1. 5).

Schist dips north as indicated by foliation attitudes, about 1,000 feet exposed; much coarser than in other exposures; composed essentially of biotite, plagioclase (andesine), and quartz; minor amounts of muscovite, epidote (clinozoisite), and iron oxides, including hematite; rock homogeneous and texture intermediate between that of schist and quartz diorite; average grain size 1-2 $\mathrm{mm}$.

Pelona Schist of eastern San Gabriel Mountains and Cajon Pass.- Schist of Cajon Pass first noted by Blake (1857, p. 88) ; correlated with Pelona Schist of Hershey (1902a) by Noble (1926b, p. 28-29, 31); described and mapped as Pelona Schist by Noble (1932, p. 11-12; 1954a ; 1954b, p. 42-43), in detail by P. H. Ehlig. ${ }^{1}$

Pelona Schist occurs southwest of San Andreas fault; divisible into two blocks separated by Punchbowl fault (pl. 1); northern block referred to as Blue Ridge block, southern block as San Gabriel Mountain block. Extends far southeast beyond border of map.

Schist of Blue Ridge block folded into tight westplunging anticline whose north flank is partly overturned and faulted out southeast of Wrightwood as indicated by foliation attitudes (pl. 1); about 8,000 feet of schist exposed; lithologically identical to that of Sierra Pelona; gray schist predominant over green schist; minor, very thin beds of quartzite and marble; occasional small masses of coarse actinolite, rare masses of talc schist; no granitic, aplitic, or diabasic dikes found.

Pelona Schist of San Gabriel Mountain block extends southeast beyond border of mapped area; arched into large northwest-plunging anticline (pl. 1) in which about 10,000 feet of schist is exposed; lowest exposed part mainly gray schist, upper part mainly

1 Ehlig, P. H., 1958, Geology of the Mount San Antonio area, San Gabriel Mountains, California: California Univ. at Los Angeles, Ph.D. thesis. green schist, grades upward into overlying mylonitic rocks. Differs from schist of Blue Ridge block in having somewhat more biotite; in scarcity of marble beds, actinolite and talc schist; and in presence of many sills and dikes of aplitic to granophyric quartz monzonite and some of diabase; near intrusive contact with quartz monzonite to southeast schist becomes subgneissic with increasing amounts of hornblende.

Pelona Schist of Tehachapi Mountains.-In Tehachapi Mountains, schistose rocks referred to Pelona Schist (of Hershey) by Wiese (1950, pl. 1, p. 12-15).

Schist crops out as a narrow strip bounded by bifurcations of the Garlock fault zone (pl. 1) ; about 5,000 feet exposed. Foliation strikes north of east parallel to boundary faults, generally vertical. Gray schist predominates over green schist; contains some thin layers of quartzite, a few small pods of actinolite schist and actinolite-talc schist.

\section{RAND SCHIST}

Rand Schist of Rand Mountains.-Schistose rocks of Rand Mountains described briefly by Hess (1910, p. 28-29, 46) and by Hershey (1902a, p. 273); named, described, and mapped as Rand Schist by Hulin (1925, p. 23-31, pl. 1), and officially adopted for use in this report.

Rand Schist folded into anticlinal arch plunging gently westward as indicated by foliation attitudes (figs. 3, 4). On north, schist overlain by gneissic rocks (Johannesburg Gneiss of Hulin), separated by possible fault or thin zone of cataclastic(?) transitional rock; on south and near Randsburg, schist intruded by quartz monzonite; extends unknown distance westward under alluviated valley, possibly to Garlock fault. Possibly 10,000 feet of schist exposed; lithology identical to that of Pelona Schist of Sierra Pelona and of Tehachapi Mountains; gray schist, predominating over green schist, contains occasional pods of fibrous actinolite schist; thin layers of quartzite and of marble, mostly in southern and western exposures. In exposures northeast of Johannesburg, albite content of schist increases to 75 percent.

Type locality of Rand Schist designated as generally north-dipping section in Rand Mountains (fig. 4), from quartz monzonite intrusion just south of Randsburg northward to contact with overlying(?) gneiss about 3 miles north of Randsburg.

\section{MESQUITE SCHIST}

Mesquite Schist of El Paso Mountains.-Schistose rocks in Mesquite Canyon, El Paso Mountains, described and mapped as Mesquite Schist by Dibblee (1952, p. 14-15), and term officially adopted for use in this report. 
Schist dips east, in contact with gneissoid quartz monzonite to west, overlain unconformably by Garlock Formation (figs. 21, 22) ; about 4,500 feet of schist exposed.

Mesquite Schist highly foliated, dark gray; composed essentially of finely divided muscovite or sericite, chlorite, and scattered minute porphyroblasts of plagioclase (albite) and quartz; foliation planes mottled with numerous minute dark-gray clusters of chlorite and quartz; some clusters contain grains of chloritoid; in one place clusters contain remnants of cordierite (R. L. Christiansen, oral commun., 1961). Finely crystalline gray-white calcitic marble occurs sporadically throughout schist as lenses parallel to foliation, from few inches to 10 feet thick; mostly in upper part of schist. Marble strata in lowest part of schist partly altered to calc-silicate hornfels.

\section{ORIGIN AND AGE}

Schistose rocks of each widely separated exposure may be correlative because of distinctive lithologic and mineralogic similarities; if so, may be remnants of once enormously thick, widespread accumulation of mostly clastic sedimentary and mafic to intermediate volcanic rocks deposited in presumably marine eugeosynclinal basin.

Calcitic marble recrystallized from limestone; quartzite metamorphosed from quartzose sandstone or possibly chert; gray schist from clay shale, siltstone, shaly sandstone or graywacke; green schist from mafic tuffaceous shale, mafic tuff, or sediments derived from basaltic rocks; actinolite-chlorite schist possibly from mafic volcanic rocks or spilite (Muehlberger and Hill, 1958, p. 640); amphibole schist and talc schist from small mafic intrusions (Simpson, 1934, p. 380; Hulin, 1925, p. 26-27).

Complete recrystallization of entire sequence into schist indicates regional metamorphism under conditions of moderately high temperature and pressure.

Schistose rocks not younger than Late Jurassic or Cretaceous, inasmuch as this is age of quartz monzonite that intrudes them; may be Mesozoic, Paleozoic, or Precambrian. Generally believed to be Precambrian (Hershey, 1902a, p. 273; Hulin, 1925, p. 29-30; Simpson, 1934, p. 380-381; Clements, 1937, p. 231; Wallace, 1949, p. 787). Age most likely Precambrian because of following evidence in Mojave Desert region : (1) schistose rocks generally in greater degree of regional metamorphism than any formations of known Paleozic or Mesozoic age as pointed out by Hulin $(1925$, p. $29-30) ;(2)$ no similar schistose rocks present in any formations of known Paleozoic or Mesozoic age 239-655 $0-67-2$ other than as detrital fragments; and (3) in Mesquite Canyon of El Paso Mountains, only place where schistose rocks and formation of Paleozoic age are in contact, Mesquite Schist unconformably overlain by comparatively less regionally metamorphosed sedimentary rocks of Garlock Formation of probable late Paleozoic age.

\section{MYLONITIC ROCKS}

Zone of mylonitic rocks exposed in eastern San Gabriel Mountains southwest of Punchbowl fault in concordant relationship with Pelona Schist below and gneissic rocks above in large anticlinal arch (pl. 1); in Lytle Canyon area mylonite zone and adjacent schistose and gneissic rocks intruded by quartz monzonite; elsewhere by several thin sills and dikes of quartz monzonite aplite.

Zone of mylonitic rocks as thick as 1,500 feet in western exposures; southeastward thins to about 250 feet near Mount San Antonio, then thickens to about 1,000 feet in Lytle Canyon. In most places mylonite grades downward into Pelona Schist, and upward into gneissic rocks. Foliation of mylonitic rocks generally parallels that of Pelona Schist and gneissic rocks.

Lithology of mylonite in San Gabriel Mountains generally conforms to the following genetic description by Waters and Campbell (1935, p. 474):

First, a mylonite is a microbreccia produced by the milling down of the original rock material into an aphanitic paste which can be resolved only by the micrascope; second, the rock must possess a flow structure, or lamination, as a result of the streaking out of the pulverized paste; third, the pulverization must have occurred under such conditions that the rock retains its coherence; and fourth, the rock must be characterized by cataclastic rather than crystalloblastic textures.

Predominant mylonite of this zone dark gray to black, hard, aphanitic; contains scattered rolled augenlike grains of plagioclase (albite or oligoclase) and quartz and uncommon to frequent white laminae of milled feldspar and quartz; dark aphanitic matrix presumably milled chloritic and biotitic flaky material and iron oxides. Subordinate mylonite, intercalated as layers, gray to tan, siliceous, presumably composed mainly of milled quartz and feldspar.

Mylonitic rocks presumably derived from shearing and milling of gneiss and schist under great pressure at depth, probably during Mesozoic Era or earlier. Mylonitic rocks older than aplite of Late Jurassic and Cretaceous ages that intrudes them. Zone of mylonitic rocks interpreted by Noble (1954b, p. 42-43, pl. 5) and Ehlig (1959) as being along a thrust fault which they called Vincent thrust, on which gneissic rocks overrode Pelona Schist. 


\section{GNEISSIC ROCKS}

The gneissic rocks are described below under their local names after a general description of their lithology.

Composition of gneissic rocks mainly that of quartz diorite. Banded or laminated gneiss alternates with or grades into gneissoid quartz diorite. Gneissic rocks are light to dark gray, fine to coarse grained, but mostly medium grained; composed largely of quartz, plagioclase (mainly andesine, some oligoclase), biotite, and hornblende in different proportions, small amounts of orthoclase feldspar present in some gneissic rocks either as small grains or as porphyroblasts; accessory minerals in very minor amounts are zircon, sphene, apatite, and iron oxides; some gneiss contains small amounts of chlorite, garnet, diopside, actinolite, and calcite.

Gneiss composed of light-gray to white laminae from one to several millimeters thick rich in quartz and feldspar that alternate with gray laminae composed of all or most essential minerals, and dark-gray to black laminae rich in biotite and (or) hornblende. Most laminae medium grained, but some fine and others coarse grained. Biotite flakes and hornblende anhedrae oriented generally parallel to laminae. Laminae commonly lenticular and undulating within small area, in places crenulated, but within large area generally regular.

Gneissoid quartz diorite homogeneous, lithologically and mineralogically similar to massive quartz diorite into which it grades; many biotite flakes and hornblende anhedrae oriented parallel to each other give rock crude gneissoid texture parallel to the laminae of intercalated gneisses.

Streaks of migmatite common in gneissic rocks, as well as lenses or zones of dark mylonite with rolled grains of feldspar and quartz.

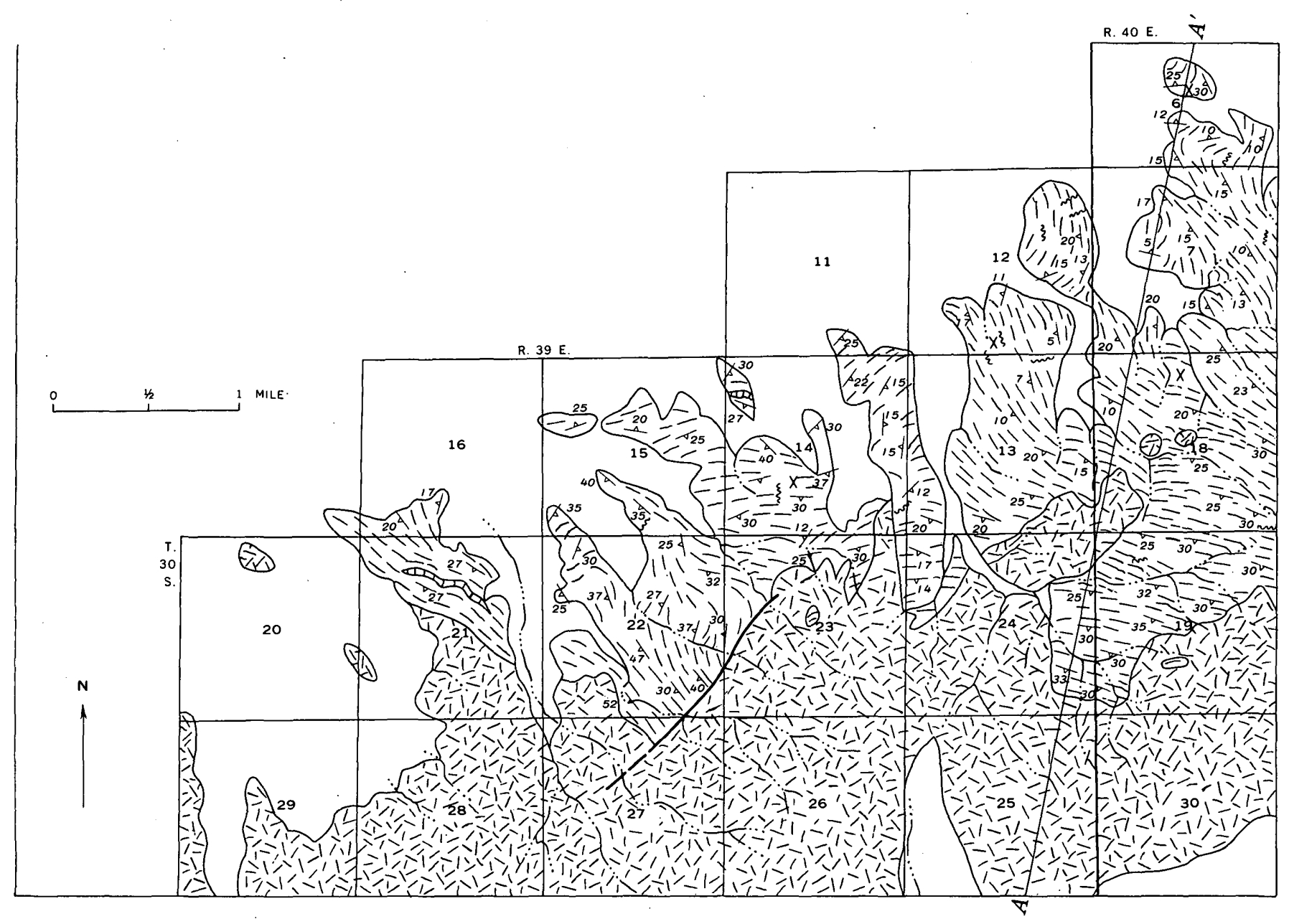

FIGURE 3.--Geologic map of central 


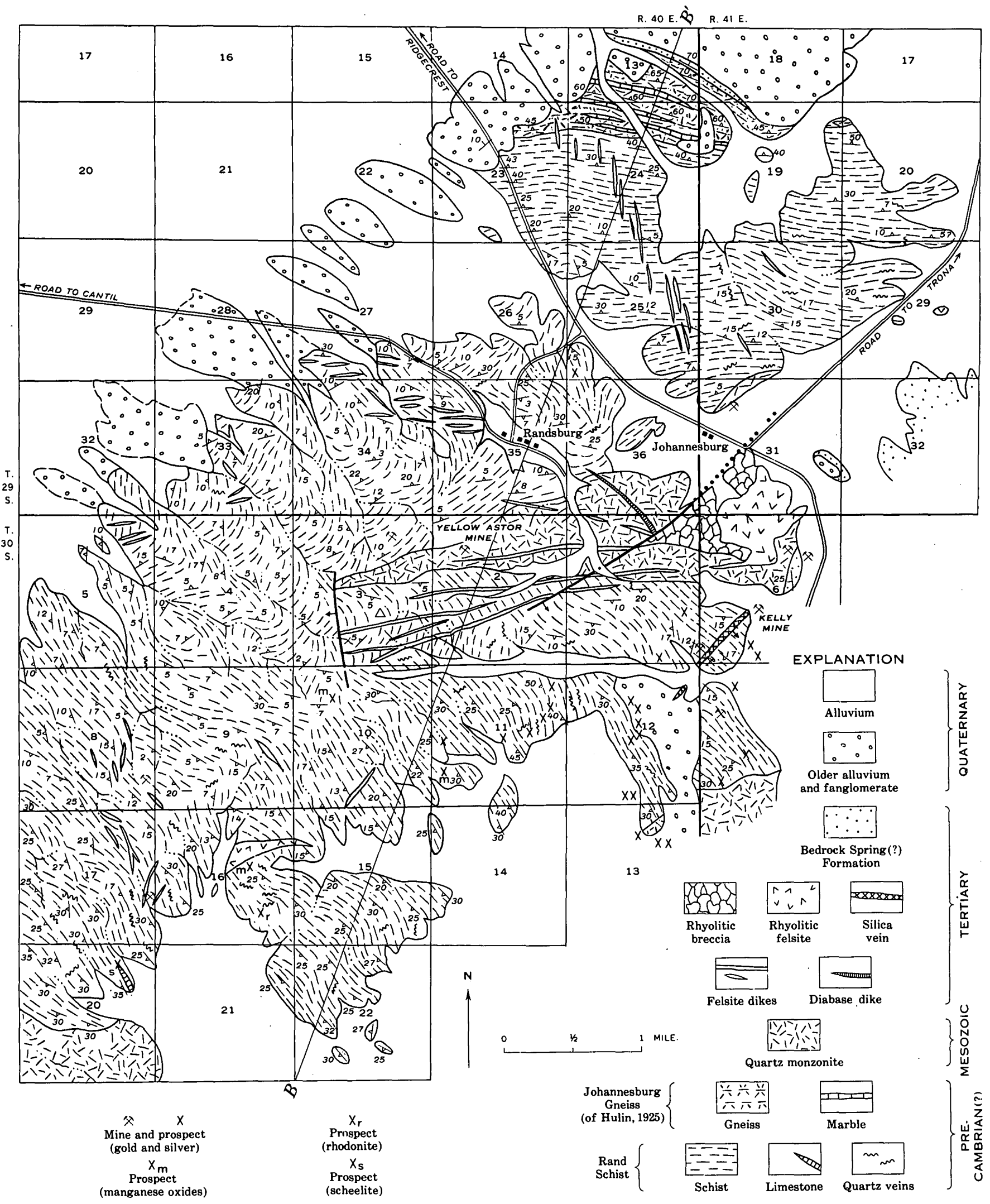

and eastern Rand Mountains. 


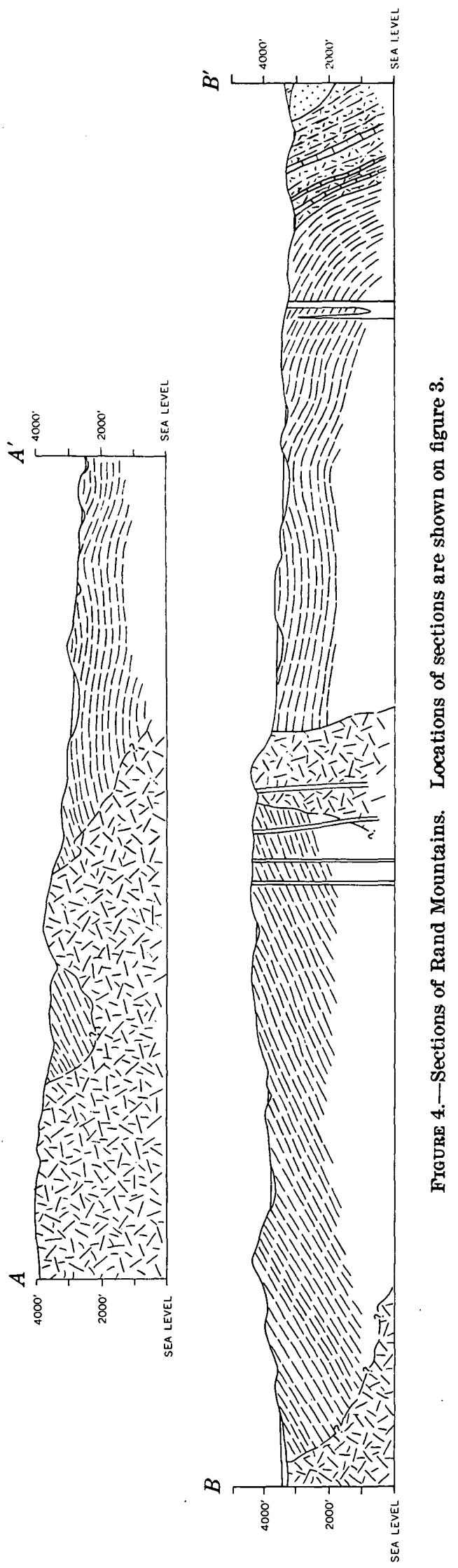


In some places gneissic rocks contain lenses of biotite schist, marble, and few of quartzite, all parallel to foliation of enclosing rocks; schist highly foliated; marble and quartzite foliated or lineated locally. Most marble lenses not more than 50 feet thick or half a mile long, few thicker and longer; marble white, massive, medium to coarsely crystalline, dolomitic to rarely calcitic, commonly contains silicates such as muscovite flakes, forsterite, diopside, and (or) antigorite; some layers contain graphite. Quartzite forms thin lenses, is light gray, massive to thin layered, vitreous, composed mainly of quartz, flakes of mica, and grains of feldspar.

\section{UNNAMED GNEISSIC ROCKS}

Gneissic rocks of San Gabriel Mountains and western San Bernardino Monntains.-In San Gabriel Mountains southwest of Punchbowl fault, sequence of gneissic rocks as thick as 10,000 feet overlies mylonitic rocks; foliation dips southwest (pl. 1). Lower part of sequence predominantly gneiss; basal part transitional through cataclastic and mylonitic gneisses into underlying mylonitic rocks; upper part mainly gneissoid quartz diorite containing zones of migmatite; no marble or quartzite; in places gneiss intruded by thin sills and dikes of aplite.

Rocks exposed on Pinyon Ridge and ridge west of Valyermo between Punchbowl and San Andreas faults mapped by Noble (1954a) as "Pinyon Ridge granodiorite," but are composed of gneiss as well as gneissoid granodiorite and quartz diorite and therefore mapped herein as gneissic rocks; foliation trends nearly eastwest, nearly vertical (figs. 29 and 30 ) ; total exposed thickness of gneissic rocks as indicated by foliation attitudes about 6,000 feet; contains no marble nor quartzite.

Foliation of gneissic rocks exposed northeast of San Andreas fault along northeast margin of San Gabriel Mountains and western San Bernardino Mountains strikes east to southeast, dips north; about 9,000 feet of foliated sequence exposed; mainly gneiss, some gneissoid quartz diorite; contains lenses of dolomitic marble as much as 300 feet thick, traceable 4 miles (pl. 1); to northeast, gneissic rocks apparently grade through gneissoid quartz diorite and granodiorite into quartz monzonite.

Gneissic rocks near Sierra Pelona.-Gneissic rocks exposed between Sierra Pelona and San Andreas fault to the north.

Complex consists of gneiss and gneissoid granitic rocks composed mainly of granodiorite, but ranging from diorite to quartz monzonite. Foliation strikes north of east, dips steeply north to vertical. About
20,000 feet of thickness exposed if homoclinal. Several lenses of marble in northern part of outcrop area; some white aplitic dikes and sills. In general, rocks grade northward from granodiorite into quartz monzonite.

Gneissic rocks of Frazier Mountain.-Rocks crop out on Frazier Mountain southwest of San Andreas fault; consist of exposed complex of gneisses and some quartz diorites intruded by aplitic dikes and sills. Some biotite gneiss with porphyroblasts or augen of potassium feldspar. Foliation of gneissic rocks much contorted but trends generally northwest, dips steeply northeast.

Gneissic rocks in mountains north of Garlock fault zone.-Gneissic rocks associated with massive to gneissoid quartz diorite exposed in Tehachapi Mountains mainly in upper El Paso Creek, described by Wiese $(1950, \mathrm{pl} .1,15)$. Also occur at southeast margin of southern Sierra Nevada where gneissic rocks contain lenses of marble. In western El Paso Mountains quartz diorite contains lenticular inclusions of biotiterich gneiss.

Gneissic rocks in western Mojave Desert.-Gneissic rocks exposed 2 miles north of Johannesburg, described and mapped as Johannesburg Gneiss by Hulin (1925, p. 21-23, pl. 1), apparently overlie his Rand Schist, dip steeply north. About 2,800 feet exposed (figs. 3, 4); some layers rich in hornblende; several layers of marble, a few of impure quartzite, all parallel to foliation of gneiss.

At Catholic Hill 4 miles east of Victorville, pendant in quartz monzonite contains nearly 1,000 feet of gneiss and intercalated quartzite; another pendant 6 miles northeast of Castle Butte contains about 500 feet of gneiss and quartzite; very small pendant of gneiss exposed a mile north of Boron.

Near Oro Grande, granite gneiss is yellowish gray, nonlaminated but foliated, fine grained; composed essentially of quartz, microcline, and plagioclase (albiteoligoclase) with slight predominance of microcline, and small percentage of biotite as small parallel flakes forming foliation of rock; feldspar occurs also as scattered grains about three times larger than average grain size of rock. Figure 14 shows structure, thickness, and relation to adjacent rocks. Gneiss in hills 6 miles south of Barstow similar but contain dark laminae rich in biotite, generally undulating, in places crenulated; injected by quartz monzonite.

\section{WATERMAN GNEISS}

Waterman Gneiss of Barstow, Hinkley, and Harper Valley areas.-Gneiss and quartz diorite containing intercalated marble and quartzite exposed in hills north of Barstow, hills near Hinkley, and hills west 
and northwest of Harper Valley. Miller (1944, pl. 6, p. 77-98) called gneissic rocks containing abundant intercalations of marble Hinkley Valley Complex, and those containing little or none, Hodge Complex. Bowen (1954, pl. 1, p. 17-22, 53-54) named gneissic rocks exposed in hills 2-4 miles north of Barstow Waterman Gneiss (type locality); those in hills northwest of Barstow he designated as gneissic hornblende diorite, and those containing abundant intercalations of marble and some quartzite exposed farther northwest in these hills, and in the vicinity of Hinkley, he referred to Oro Grande Series. In this report all these gneissic rocks are included in Waterman Gneiss because all are physically and lithologically similar, appear to be regionally metamorphosed to same extent, and are physically unlike Oro Grande Formation.

Planar foliation in Waterman Gneiss generally conspicuous and parallel to lenses of marble and quartzite, but in many places obscured by lineations of various attitudes and by minor crenulations formed by plastic flow formed during metamorphism, as shown by Wiese (1954). In hills 2-4 miles north of Barstow attitudes of discernible planar foliation indicate several folds having axes trending northeast (figs. 5 and 6), which apparently expose possibly 4,000 feet of gneissic rocks containing intercalations of marble as thick as $\mathbf{5 0}$ feet; some partly containing specular hematite. Lithology and planar structure of Waterman Gneiss in hills 1-6 miles northwest of Barstow nearly similar except part contains more intercalations of marble and some of quartzite (fig. 5), possibly about 5,000 feet of gneissic rocks exposed. In both areas, gneiss grades through gneissoid quartz diorite into granodiorite or quartz monzonite to northwest.

In Iron Mountain area southwest of Hinkley, about 8,000 feet of nearly vertical Waterman Gneiss exposed; includes layers of marble as thick as 300 feet (figs. 7, 8). Gneiss grades into gneissoid quartz diorite to northwest. In low hills northwest of Hinkley, pendants of gneissic rocks contain several layers of quartzite (fig. 9); other pendants west of Harper Valley contain many layers of dolomitic marble (fig. 10) that locally contain forsterite (partly altered to antigorite), diopside, magnesium spinel, and other magnesium silicate minerals.

\section{ORIGIN AND AGE}

Gneissic rocks recrystallized at moderate to great depth under conditions of high temperature; possibly partly melted in place or partly magmatic in origin. Gneiss probably recrystallized from sedimentary rocks as indicated by intercalations of marble, quartzite, and biotite schist; possibly in part crystallized from magmas or solutions injected along foliation planes.
Gneissic rocks intruded by plutonic rocks of Late Jurassic or Cretaceous age, therefore older. In western San Gabriel Mountains, gneiss intruded by gabbronorite and anorthosite dated by lead: alpha measurements on zircon as $930 \pm 90$ and $810 \pm 80$ million years, or Precambrian (Neuerburg and Gottfried, 1954, p. 465; Oakeshott, 1958, p. 24, 48). In Bear Valley area of San Bernardino Mountains, gneiss overlain with angular unconformity by Paleozoic sedimentary rocks. Therefore most if not all gneiss and included metamorphic rocks in western Mojave Desert probably Precambrian. However, gneissoid quartz diorites and migmatic gneisses may be younger, possibly Mesozoic. Age relation of gneissic rocks to schistose rocks is controversial and requires further study.

\section{METASEDIMENTARY ROCKS}

Remnants of a once-extensive and thick sequence or sequences of metasedimentary rocks of marine origin are exposed as isolated pendants in the batholithic masses of Mesozoic granitic rocks of the Mojave Desert, mostly in the southeastern part of the area and in the mountains along the northwestern border.

The metasedimentary rocks are generally similar in their lithologic character, and in their relatively low grade stage of regional metamorphism as compared to that of the older dynamothermal metamorphic rocks. However, the stratigraphic sequence of each pendant is different, and with few exceptions, unfossiliferous, so that definite correlations and precise reconstruction of stratigraphy are not possible. The few fossils found in some pendants are all marine types known from rocks of late Paleozoic age. Consequently the metasedimentary rocks are presumed to be of that age, although some may be as old as Precambrian and some as young as Mesozoic.

Five local formational units are shown on plate 1, but because of their isolated positions and the scarcity of fossils, their ages and stratigraphic order are not completely known. The units are: unnamed metasedimentary rocks, Bean Canyon Formation, Oro Grande Formation, Fairview Valley Formation, and Garlock Formation.

\section{UNNAMED METASEDIMENTARY ROCKS}

Metasedimentary rocks of El Paso Mountains.Rocks occur as a thin pendant across western El Paso Mountains, 1 mile east of Redrock Canyon (fig. 63, pl. 1). Consist of quartzite, metaconglomerate, and hornfelsic rocks. Conglomerate predominates in lower (western) part, hornfelsic rocks elsewhere. Metaconglomerate composed of originally rounded pebbles as much as 2 inches long in somewhat schistose dark-gray matrix of impure micaceous quartzite; pebbles flattened 


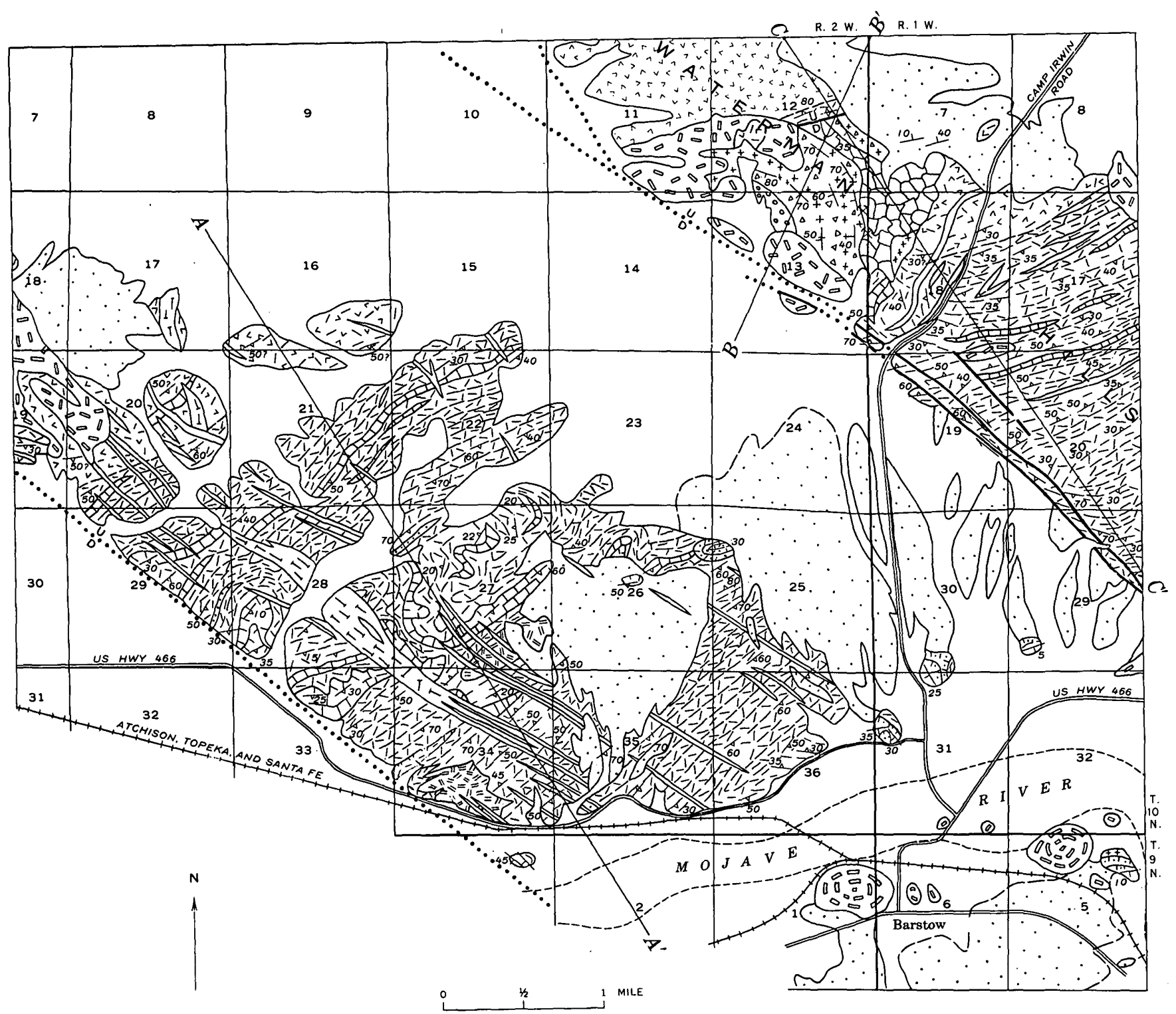

Figure 5.-Geologic map of hills north of Barstow. See figure 6 for explanation and sections. 

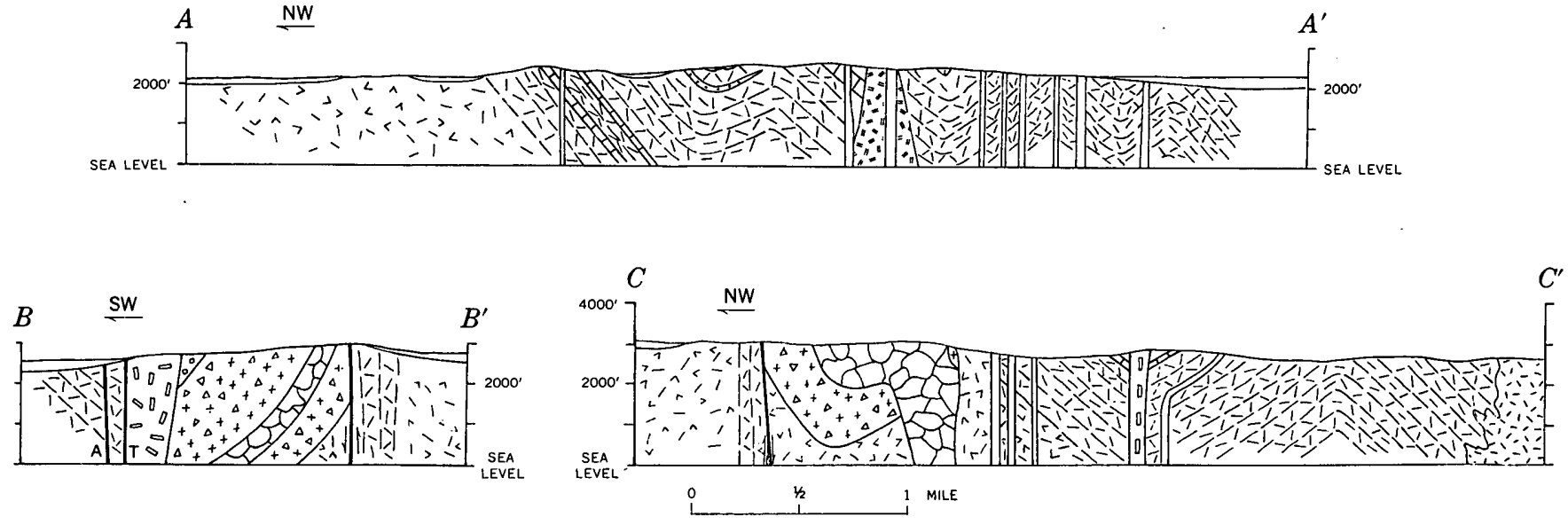

EXPLANATION

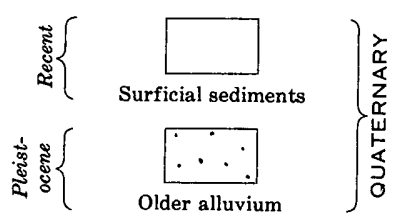

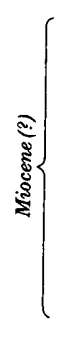
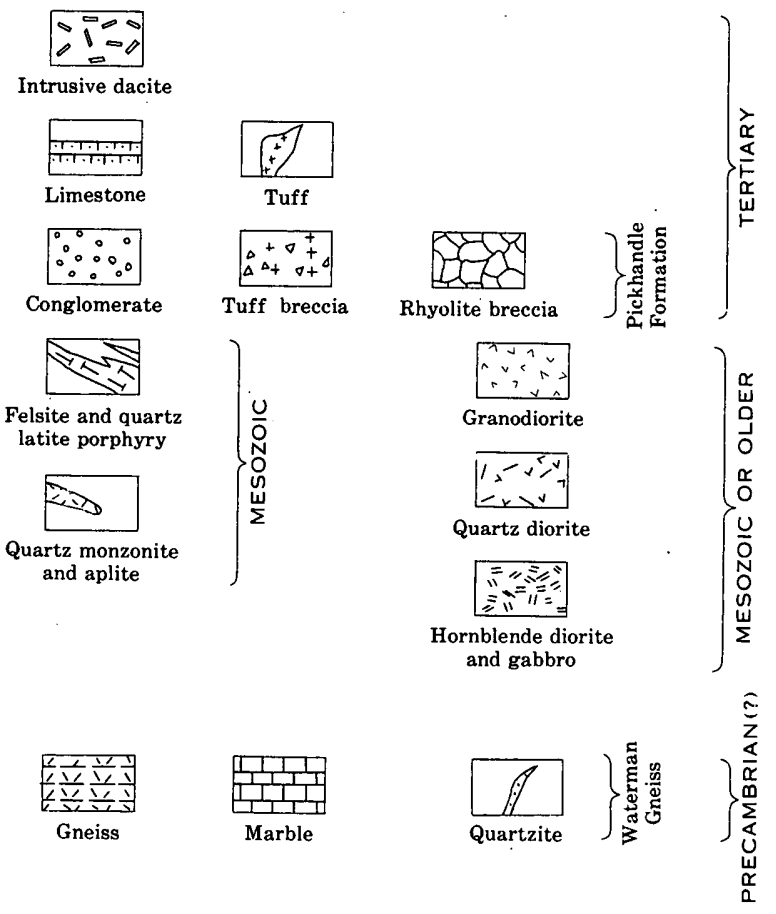

FrguRE 6.-Sections of hills north of Barstow. Locations of sections are shown on figure 5. 
PRE-TERTIARY CRYSTALLINE ROCKS

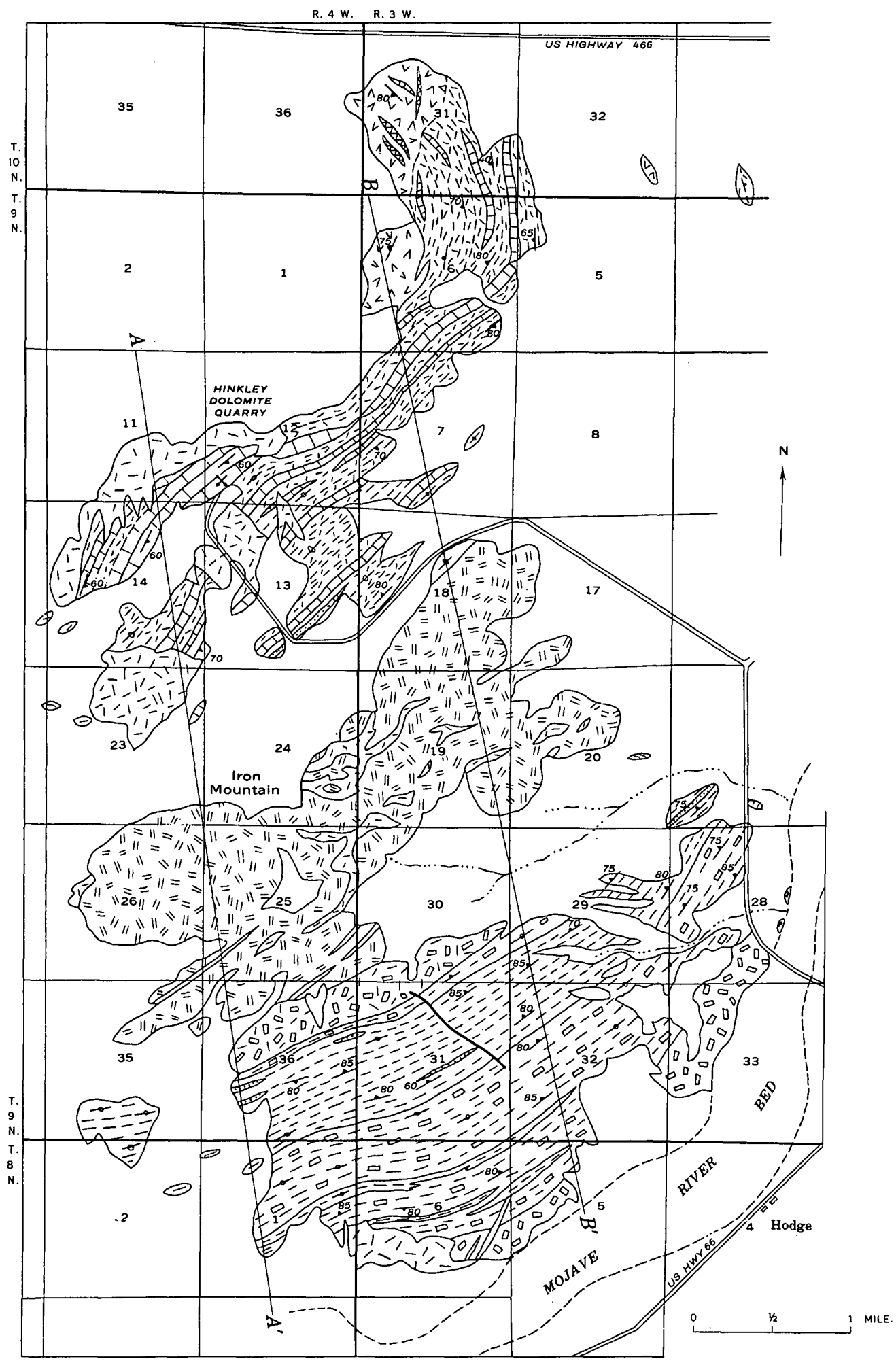

FIGURE 7.-Pre-Tertiary geology of Iron Mountain area. See figure 8 for explanation and sections. 
$\underline{s}$
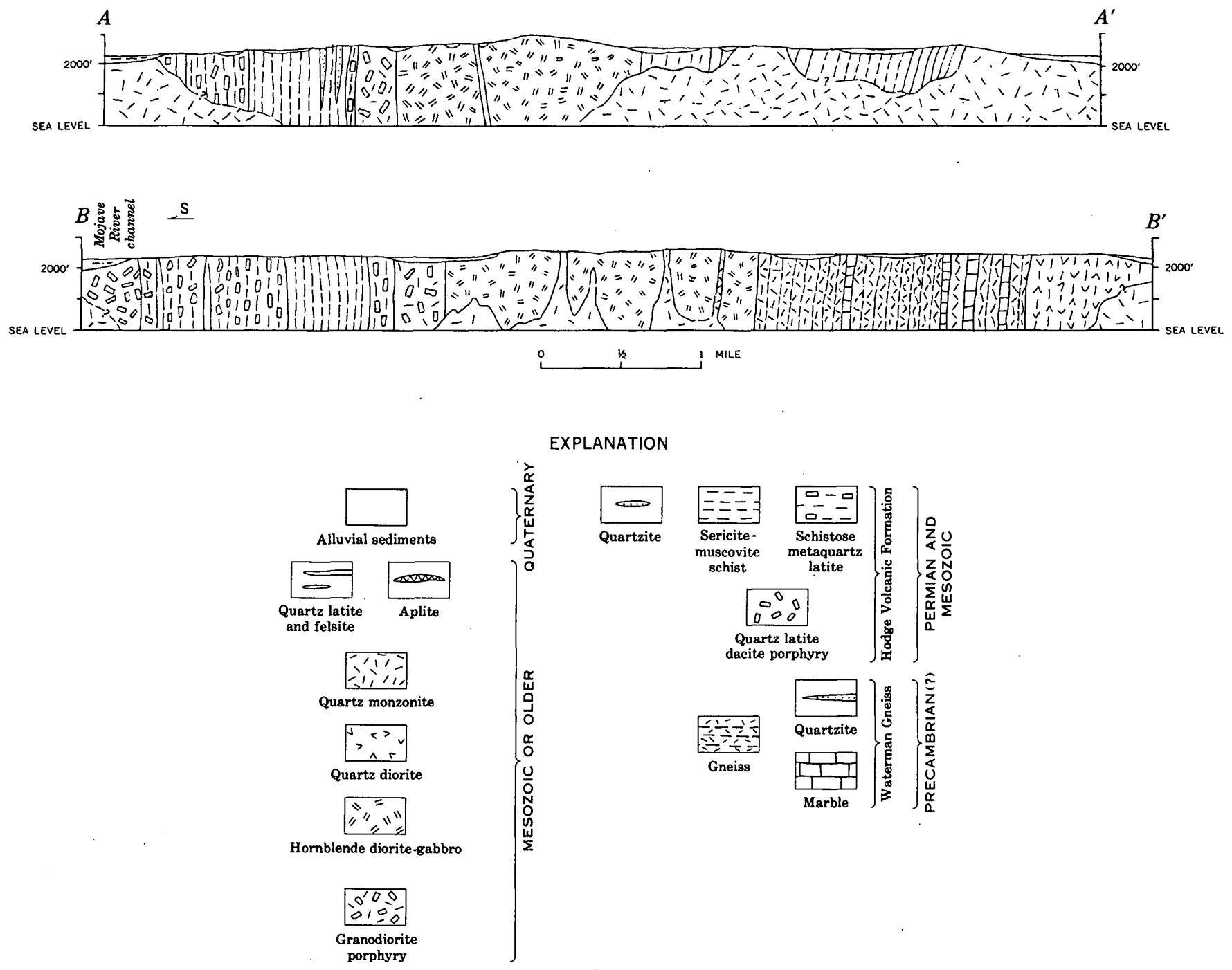

EXPLANATION

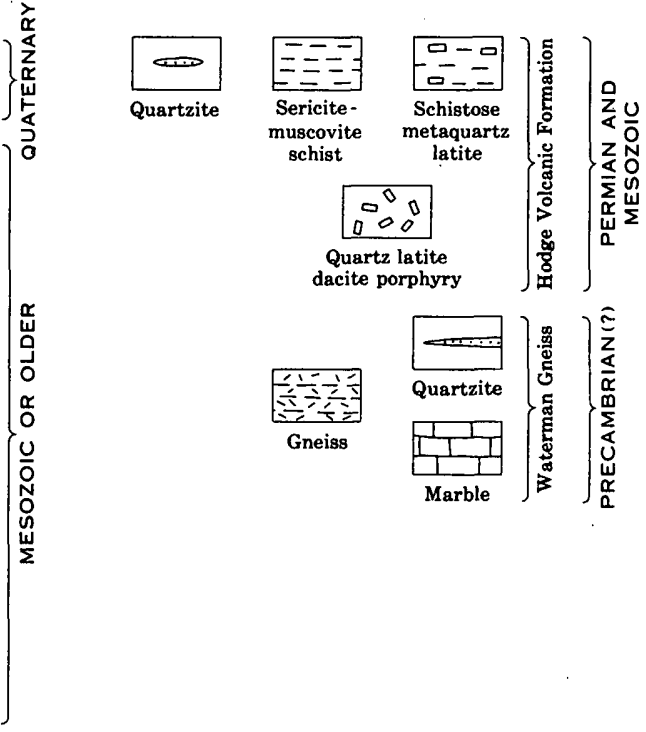

Frgure 8.-Sections of Iron Mountain area. Locations of sections a re shown on figure 7. 


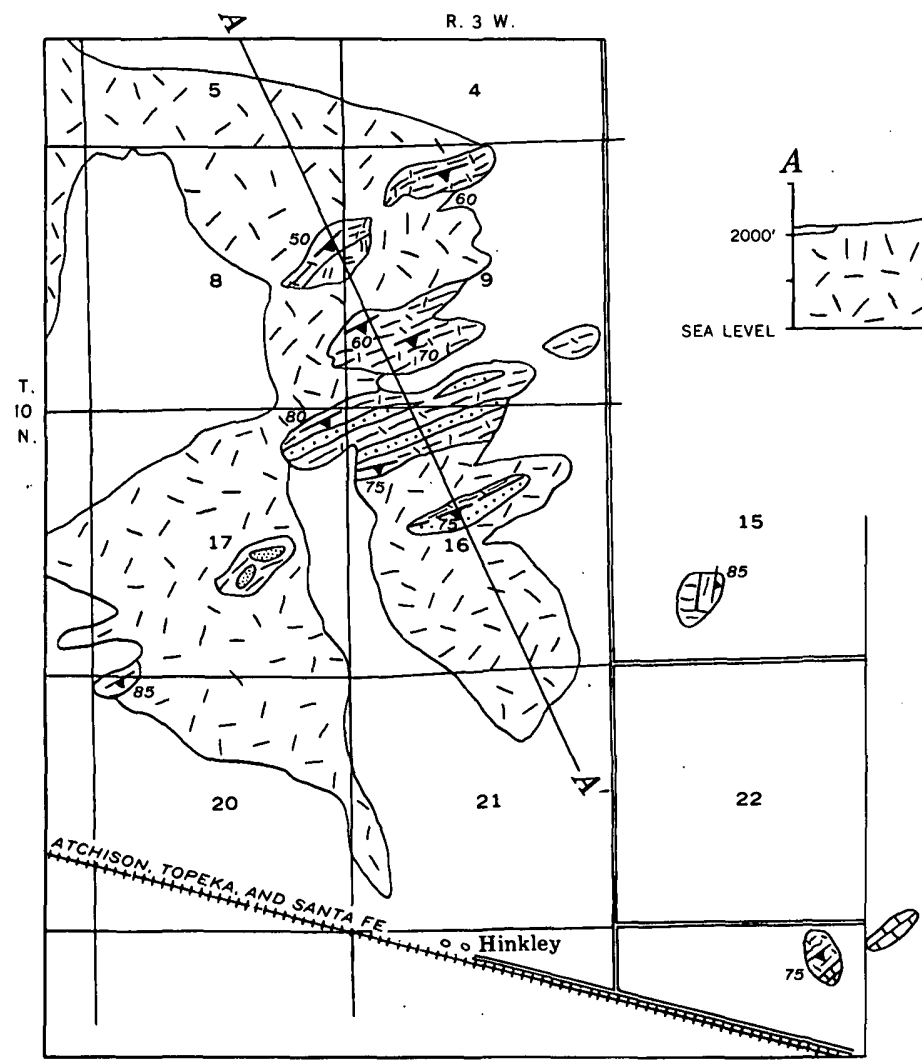

Figure 9.-Geologic map and sections of hills north of Hinkley.

parallel to schistosity of matrix; most pebbles of graywhite quartz, few of tan to brown felsites. Hornfelsic rocks massive to indistinctly bedded, compact, microcrystalline; composed of dark-greenish-brown nodular calc-silicate rocks and dark-brownish-gray to nearly black metamorphosed andesite or basalt.

Fine-grain size and inferred mineralogy suggest lowgrade regional metamorphism; age uncertain but on plate 1 assigned to Paleozoic for simplicity.

Metasedimentary rocks of southern Sierra Nevada and northern Tehachapi Monntains.-Biotite schist and marble, in part migmatized, presumably of Paleozoic age; occur as small isolated pendants in plutonic rocks of mountains west of Sierra Nevada fault and northwest of Garlock fault (pl. 1).

Metasedimentary rocks of southwestern Tehachapi Mountains.-Pendants of white to light-gray marble, some hornfels, schist, quartzite, and tactite; occur in granite in southwestern Tehachapi Mountains southeast of Garlock fault (fig. 11). Described and mapped as Paleozoic (?) rocks by Wiese (1950, pl. 1, p. 16-19) and metamorphosed Paleozoic(?) sedimentary rocks by Crowell (1952, pl. 1, p. 6). Rocks similar to Bean Canyon Formation to northeast.

\section{BEAN CANYON FORMATION}

Pendants of metasedimentary rocks exposed in eastern Tehachapi Mountains southeast of Garlock fault mapped as Bean Canyon Formation (figs. 12, 13) originally named Bean Canyon Series by Simpson (1934, p. 381-383, pl. 5). Pendant in Bean Canyon designated type section (fig. 13).

Rocks composed of nearly two-thirds meta-argillite or fine-grained dark schist, about one-third carbonate rocks, and minor amounts of quartzite and metabasalt. Metabasalt (only in Bean Canyon pendant, fig. 13) is black, locally amygdaloidal, fine grained; composed of dark plagioclase and ferromagnesian minerals largely altered to antigorite, chlorite, and iron oxide.

Rocks unfossiliferous, therefore of doubtful age. General lithologic similarity to known Paleozoic metasedimentary rocks and apparent similarity in stage of regional metamorphism süggest formation most likely Paleozoic in age.

\section{ORO GRANDE FORMATION}

Oro Grande(?) Formation of Oro Grande-Victorville area.-Sequence of carbonate rocks, calc-silicate hornfels, schist, and quartzite east of Oro Grande and Victorville (pl. 1) originally described as Oro Grande 

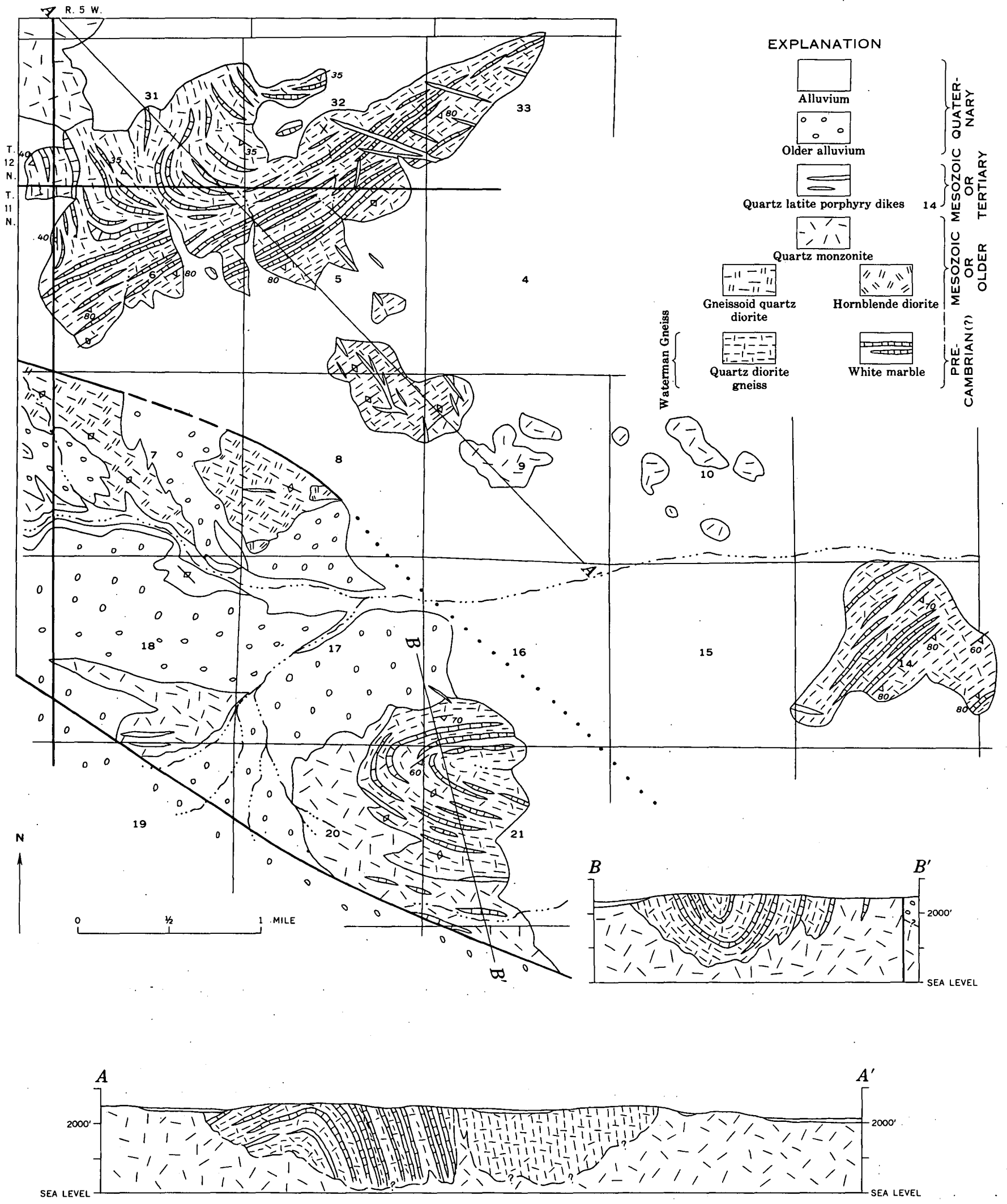

Frgure 10.-Geologic map and sections of hills west of Harper Valley. 


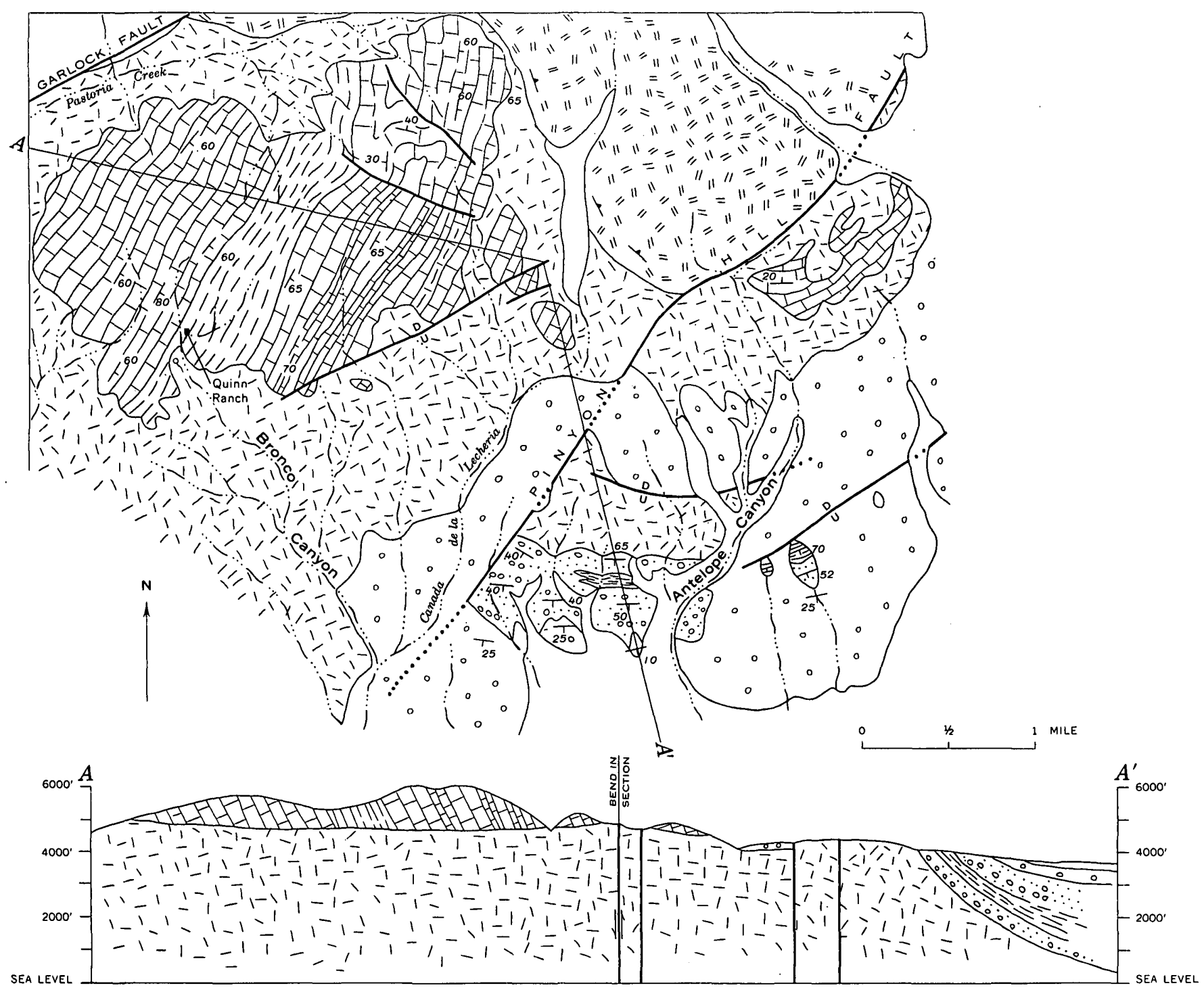

EXPLANATION
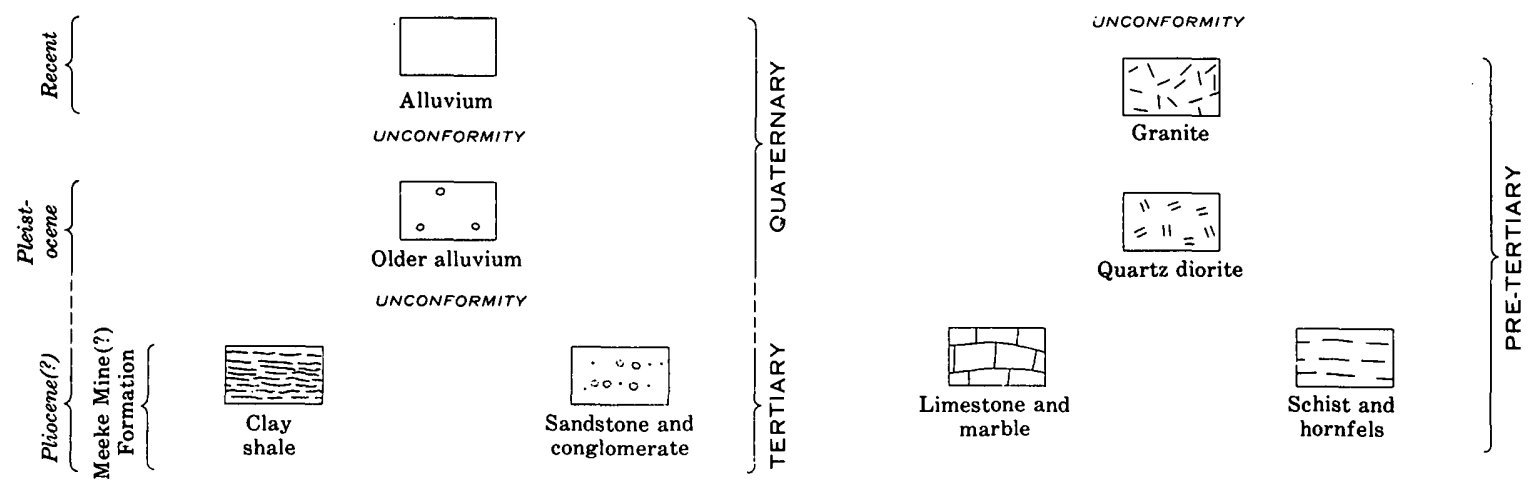

Frgure 11.-Geologic map and sections of Bronco and Antelope Canyon area, Tehachapi Mountains (modified after Wiese, 1950). 

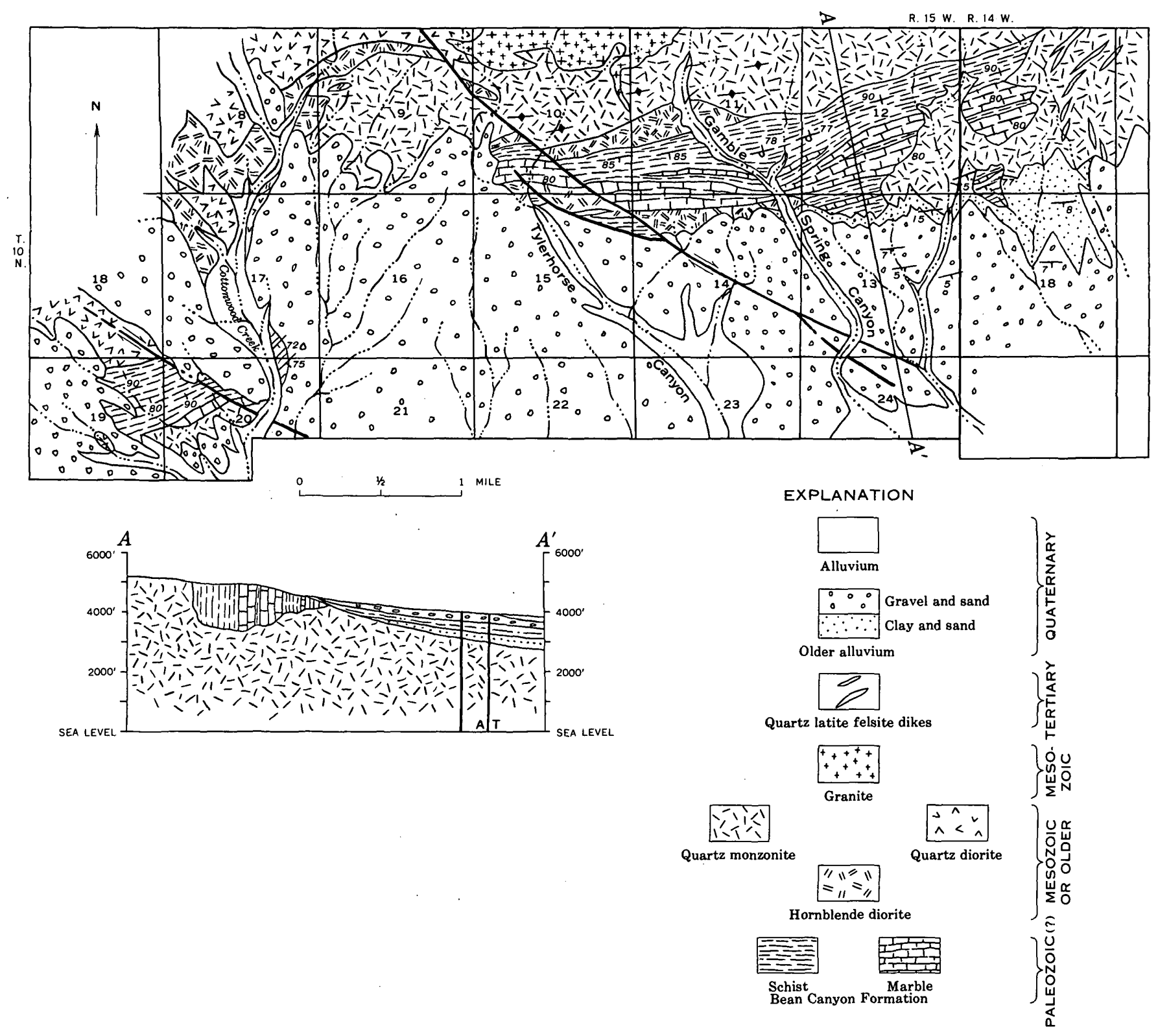

FIgURE 12.-Geologic map and sections of Tehachapi Mountain foothills in vicinity of Tylerhorse Canyon. 
Series by Hershey (1902a, p. 278-288), later by Baker (1911, p. 334-335) and Darton and others (1915, p. 163). Described and mapped by Miller (1944, p. 98) and Bowen (1954, pls. 1, 6, p. 23-26). Outcrop at Quartzite Mountain near Oro Grande designated as the type section by Bowen (1954, p. 24-25).

Oro Grande Formation characterized by lenticularity of units (figs. 14, 15) ; sequence at Quartzite Mountain as given below in descending order (northeast to southwest).

Oro Grande Formation of Quartzite Mountain area (secs. 9, 10, 11, 14, 15, 16, 17, T. 6 N., R. \&. W., fig. 14)

Metamorphosed felsite agglomerate.

Unconformity (?).

Schist, dark-gray, very fine grained. . . . . . . . . . .

Limestone marble, blue-gray, bedded, finely crystalline - . . . . -

Schist, dark-gray, thin-bedded, very fine grained, micaceous; thins eastward . . . . . . . . . . . . . . . .

Limestone marble, blue-gray, bedded, finely crys. talline; thins eastward......................

Quartzite, pinkish-tan, massive, fine-grained; contains intercalated limestone in sec. 11. . . . . . . .

Schist, black, thin-bedded, very fine grained micaceous; includes a few thin beds of limestone marble; thickens eastward . . . . . . . . . . . ........

Dolomite marble, white, thick-bedded, fine to coarsely crystalline........................

Schist, dark-gray, fine-grained, micaceous........

Limestone marble, blue-gray, bedded, finely crys-

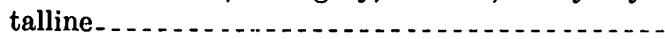

Schist, dark-gray, fine-grained, micaceous........

Quartzite, pinkish-tan, massive, fine-grained; forms ridge of Quartzite Peak.

Hornfels, pinkish- to greenish-gray, bedded, very fine grained calc-silicate layers; thins eastward.

Schist, gray-black, thin-bedded, very fine grained, micaceous; contains a few thin interbeds of bluegray limestone marble; thins or grades laterally westward into overlying hornfels.

Estimated thickness (feet) $0-100$

$250-400$

$0-500$

$0-800$

0-200

$200-700$

$1,000-1,200$

0-200

100-250

100-350

$150-300$

$0-150$

Schist, like that above; contains several lenses as much as $300 \mathrm{ft}$ thick of blue-gray limestone and dolomite marble and two lenses as much as $150 \mathrm{ft}$ thick of tan quartzite.............. 1, 000-1, 600

Total approximate thickness of Oro Grande Formation

Granite gneiss.

In hills 2-4 miles northeast of Victorville is a 3-milelong pendant of Oro Grande in plutonic rocks. Northern part marble, about 500 feet thick; southern part black fine-grained schist containing lenses of white marble and one of quartzite, flanked on east by metamorphosed quartz latite(?).

Oro Grande (?) Formation of Shadow Mountains.Metasedimentary rocks preserved as large pendant in northern part (Troxel, 1954) and another in southern part of Shadow Mountains questionably referred to Oro Grande Formation (figs. 16, 17). Both pendants partial sequences, complexly deformed; neither base nor top preserved. Thicknesses of lithologic units within each pendant differ greatly, perhaps because of plastic flow during deformation accompanying metamorphism.

Oro Grande(?) Formation exposed on southeas! flank of anticline in northern Shadow Mountains (secs. 29, 31, 32, 39, 34, T. 8 N., R. $6 \mathrm{~W}$., fig. 16, east (o west)

Top of section concealed by alluvium, and intruded by quartz monzonite to west.

Marble, white to gray-white

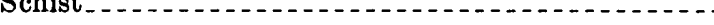

Dolomite marble, white; lenses out(?) to west. .....

Schist; lenses out to west, then reappears.........

Dolomite marble, white; lenses out to west, then reappears west of fault as a thin layer............

Dolomite marble, white; thins westward; forms crest of mountains. .

Quartzite; lenses out to west and east . . ....... 0-30

Hornfels...

Schist . .

Quartzite; lenses out to west and east_........... 0-50

Hornfels and schist; contain several thin layers of marble.

$0-50$

Granitic intrusions on axis of overturned anticline. Total thickness exposed.

Oro Grande(?) Formation exposed in southeastern Shadow Mountains (secs. $30,31, T .7$ N., R. 5 W., secs. $25,26,27,34,35,36$, T. 7 N., R. 6 W., fig. 17, west to east)

Thrust fault at top of section.

Hornfels; contains some interickess

thin layers of light-gray limestone marble..... 800

Limestone marble, blue-gray; contains about $50 \mathrm{ft}$ of schist near base that wedges out northward . . . . . 1, 200

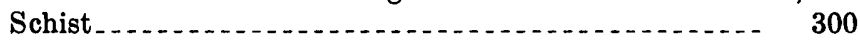

Limestone marble, blue-gray . . . . . . . . . . . . . . . 200

Hornfels; contains some intercalated schist and thin layers of limestone marble, a few of quartzite; lower part concealed by alluvium. . . . . . . . . . . . . .

Concealed by alluvium, but iso'ated exposures of light blue-gray limestone marble in sec. 30 , T. 7 N., R. 6 W.

Hornfels, synclinally folded; top concealed by alluvium -

Limestone marble, gray-white

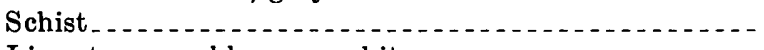

Limestone marble, gray-white

Schist; wedges out northward . . . . . . . . . . . . . . . . .

Marble, white; base concealed by alluvium

600

$150+$

$200+$

150

500

250

500

$250^{\prime}$

400

Total thickness exposed . . . . 5, 500+. 


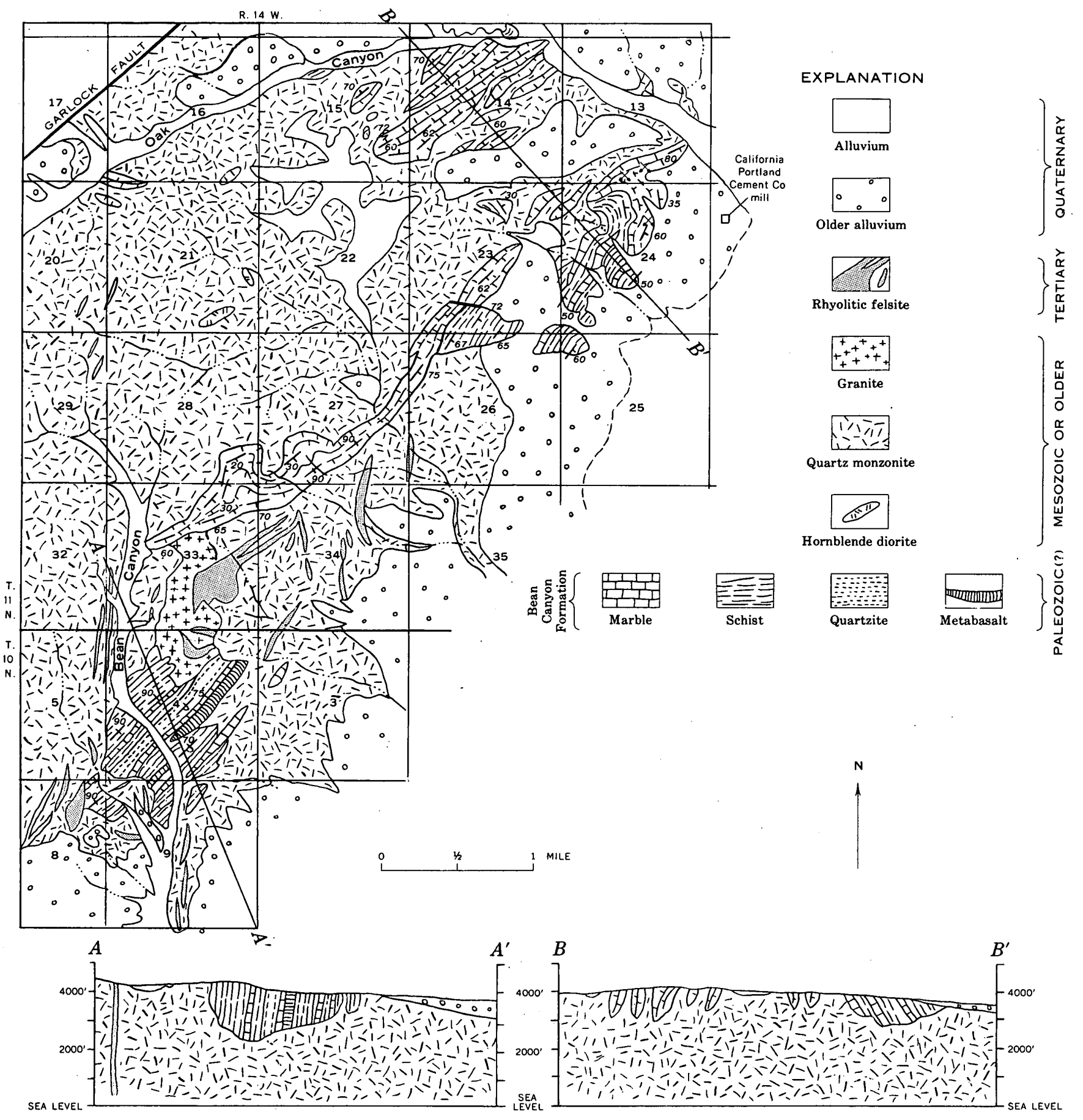

FIgURE 13.-Geologic map and sections of Tehachapi Mountain foothills between Bean Canyon and Oak Oanyon. 
Oro Grande Formation exposed in central southern part of Shadow Mountains (secs. 27, 28, 39, 34, T. 7 N., R. $6 \mathrm{~W}$., fig. 17, east to west)

Thrust fault at top of section.

Schist

Hornfels; contains intercalated schist and a few thin lenses of limestone marble ........................ 1, 200

Schist; includes some intercalated hornfels and lenses of light blue-gray marble as much as $200 \mathrm{ft}$ thick; anticlinally folded and intruded from below by quartz monzonite 1,500

Total thickness exposed 4,500

Oro Grande Formation exposed in southwestern Shadow Mountains (sec. 32, T. 7 N., R. 6 W., secs. 4, 5, 8, 9, 16, T. 6 N., R. $6 \mathrm{~W}$., fig. 17, northwest to southeast)

Intrusive quartz monzonite.

Schist; includes a few thin layers of marble and calc-sili-

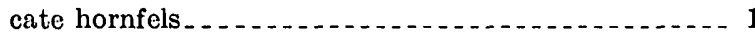

Marble, white; fine-crystalline

Schist. . . . . .

Limestone marble, blue-gray

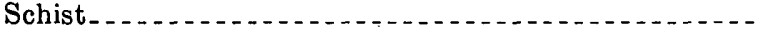

Limestone marble, blue-gray; in part intertongues northwestward into schist; basal part concealed by

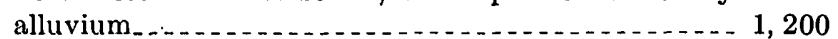

Schist; contains some intercalated hornfels and marble exposed only in an isolated hill (in sec. 8) surrounded by alluvium.

Total thickness exposed. $4,600 \pm$

Oro Grande(?) Formation of Sidewinder Mountain area.- In east-trending ridge at north end of Sidewinder Mountain, 15 miles east of Oro Grande, remnants of metasedimentary rocks referred to Oro Grande Formation by Bowen (1954, p. 27-31, pl. 1). Occurs here as two large pendants (fig. 18). Another exposure in Black Mountain west of Sidewinder Mountain (fig. 20). Small pendants in Granite Mountains.

One large pendant in Sidewinder Mountain composed of dark biotite schist, dolomite marble, and thin layers of quartzite. Another consists of black micaceous schist and white dolomite marble. In Black Mountain mainly gray-white limestone marble containing thin intercalations of hornfelsic calc-silicate rock; uppermost part altered to massive tactite (Bowen, 1954, p. 33, 34). Small pendants in Granite Mountain, marble, biotite schist, and quartzite; in places marble silicated to tactite or metasomatized to hornblende diorite or gabbro.

Oro Grande(?) Formation of Juniper Flat area.-
In Juniper Flat area of northwestern San Bernardino Mountains gray-white dolomitic marble and black finegrained biotite schist, similar to Oro Grande Formation, prominently exposed as pendants in plutonic rocks (fig. 19).

Crinoid stems suggesting Carboniferous age reported from west slope of Juniper Flat by Noble (1932).

\section{FAIRVIEW VAITEY FORMATION}

Fairview Valley Formation of Black Mountain area. -Sequence of hornfels, limestone, and conglomerate exposed in Black Mountain and hills to west about 15 miles east of Oro Grande (fig. 20) described, mapped, and named Fairview Valley Formation by Bowen $(1954$, p. $36-42$, pl. 1), and officially adopted for use in this report. Probably unconformable on marble of Oro Grande Formation, if not in fault contact.

Lower unit of formation composed mainly of darkgreenish- to brownish-gray, laminated thin-bedded platy hornfels; contains several units as much as 300 feet thick of dark-greenish-brown ferruginous limestone and interstratified platy hornfels; individual limestone beds not more than 5 feet thick; several layers 1-25 feet thick of pebble conglomerate composed of scattered to abundant subrounded pebbles of porphyritic andesitic rocks, granitic rocks, quartzite, hornfels, and limestone in matrix of sandy or gritty hornfels or gray arkosic metasandstone.

Upper unit composed of limestone cobble conglomerate containing poorly sorted rounded clasts as much as 2 feet in diameter of dark-blue-gray to black limestone in matrix of dark-gray fragmental limestone; few clasts of brown quartzite and chert.

Fairview Valley(?) Formation in Sidewinder Mountain.-Dolomitic breccia or conglomerate at Three Color Marble quarry on north side of Sidewinder Mountain (fig. 18) described by Pack (1914a, p. 363-368) and Bowen (1954, p. 30, 146-147, figs, 7, 8, 68). Referred to Fairview Valley Formation. About 200 feet thick. Composed of well-sorted subrounded to angular pebbles and cobbles of white dolomite in greenish-gray to greenish-black, partly silicated; dolomitic marble; no fossils found. Unconformable on white marble of Oro Grande(?) Formation.

Fairview Valley(?) Formation near Sparkhule Wountain.-About 200 feet of limestone conglomerate exposed just north of Sparkhule Mountain (fig. 14); composed of flattened cobbles and pebbles of black limestone in dark-gray limestone matrix; rock weathers light brown. 


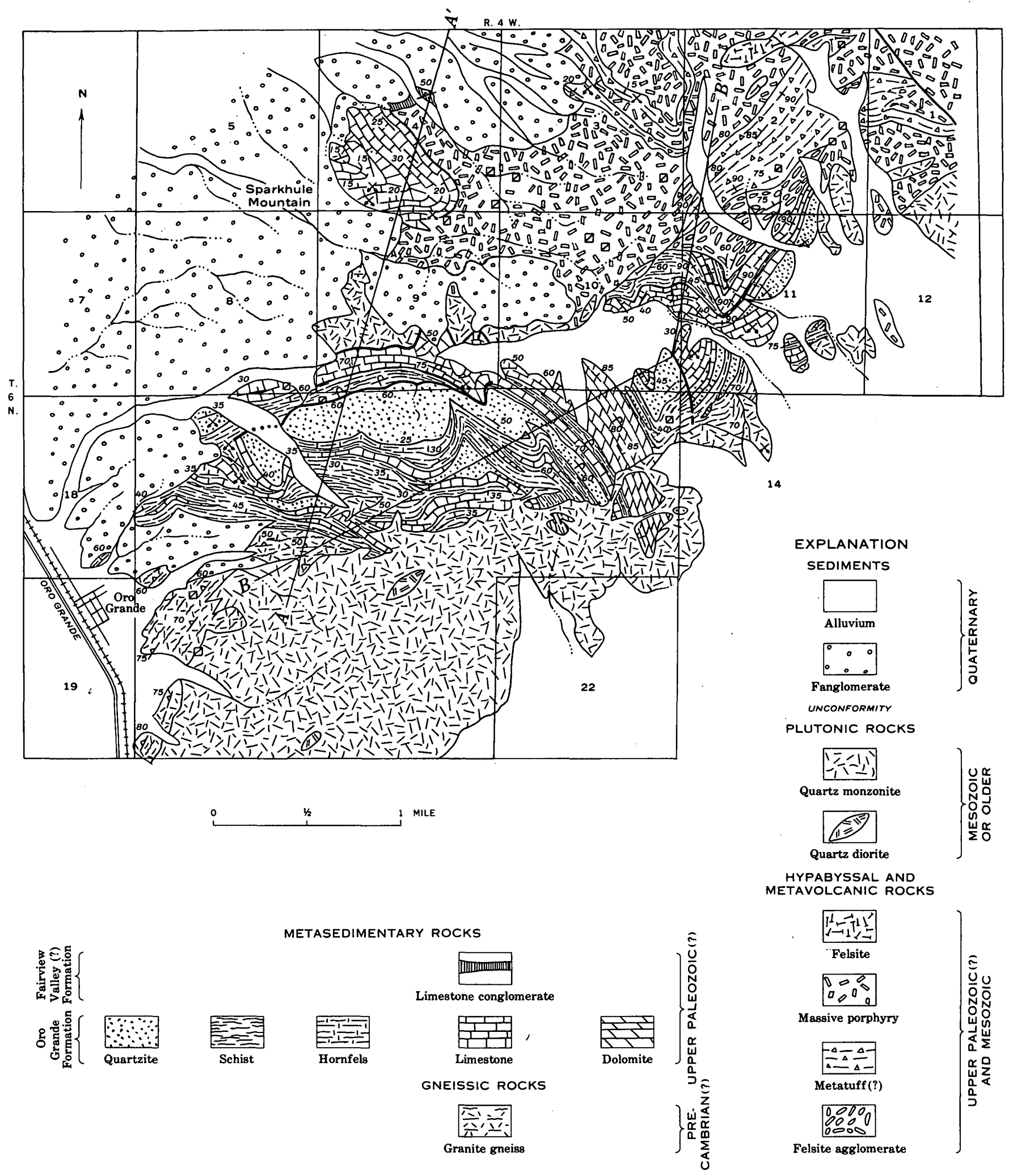

FIgURE 14.-Geologic map of Quartzite Mountain area. 

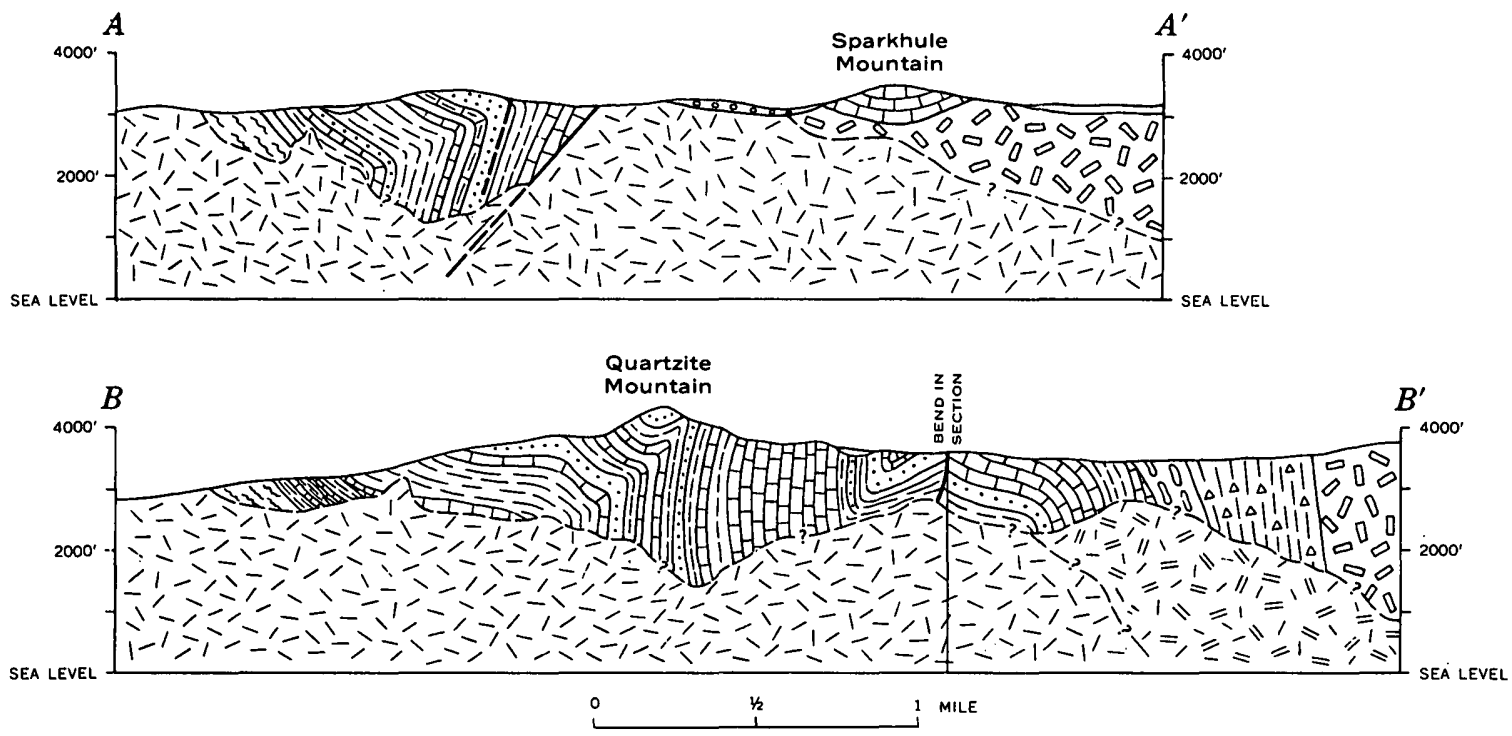

Figure 15.-Sections of Quartzite Mountain area. Locations of sections are shown on figure 14.

\section{GARLOCK FORMATION}

Garlock Formation of El Paso Mountains.-Garlock Formation originally described and mapped as Garlock Series (Dibblee, 1952, p. 15-19, pl. 1); superbly exposed in central El Paso Mountains; officially adopted for use in this report as Garlock Formation.

Garlock Formation differentiated into 22 units as shown on figures 21 and 22 . Lithology and stratigraphic sequence of units in descending order are shown below.

Unit

\section{Garlock Formation of El Paso Mountains}

22. Tactite: stratified to massive greenishbrown fine- to medium-crystalline garnet-epidote rock.

Estimated thicknes (feet)

Hornfels: stratified to massive brownishgray finely crystalline calc-silicate rock and micaceous schist; grades southeastward into white marble

21. Phyllite, stratified, dark-brownish-gray, micaceous; grades into mica-quartz schist near quartz diorite contact.... 1, 000-2, 000

20. Hornfels: thin-bedded tan to light-gray aphanitic calc-silicate rocks; interbedded with platy calcareous to micaceous phyllite; contains $\mathbf{0 - 3 0 - f t - t h i c k ~ l e n s ~}$ of black chert in upper part; 0-30-ftthick lens of brown quartzite in lower part

Chert: black, thin-bedded............

19. Phyllite and hornfels: thin-bedded gray micaceous slaty phyllite; interbedded gray to pinkish-tan calc-silicate hornfels; contain few lenses of gray marble and dark chert
Garlock Formation of El Paso Mountains-Continued Unit

18. Phyllite, gray, thin-bedded, micaceous; contains some interbedded calc-silicate hornfels and lenses of gray marble....

Chert, black to gray, thin-bedded; contains thin layers of marble . . . . . . . . . .

Hornfels, cream-tan to greenish-gray, thin-bedded; contains some interbedded dark-brown slaty phyllite; 0-100 ft of dark chert and siliceous phyllite at base

Heterogeneous rocks: interbedded darkgray slaty phyllite, tan to light-gray calc-silicate hornfels, dark chert, and gray limestone marble containing crinoid fragments; 0-100 ft of greenstone near middle.

Total thickness unit 18 . . . . . . .

17. Phyllite, dark-gray, thin-bedded, slaty, micaceous; weathers brown :........ 1, 600-2, 500

16. Heterogeneous rocks: interbedded darkgray slaty phyllite, light-colored calcsilicate hornfels, dark-colored chert, and some gray marble . . . . . .

15. Phyllite: similar to that of unit 17....

14. Chert and phyllite, gray to black, thinbedded; a few lenses of chert-pebble conglomerate as much as $2 \mathrm{ft}$ thick. - -

13. Andesite, dark-gray, porphyritic....... Limestone, dark-gray, massive Chert, black to brown-gray, and tuffaceous(?) phyllite.......................

\section{Estimated (feet)

900-2, 000

$500-700$

$600-1,300$ 700 50 300 
Garlock Formation of El Paso Mountains-Continued

Andesite: like that above; thickens southeastward; contains tongues of chert to northwest; in Iron Canyon lower $0-100 \mathrm{ft}$ altered to pink-gray sheared sericitized schistose material_- 1, 100-3, 100

Andesite, flow breccia, and tuff breccia, pink-gray to brown, somewhat schistose.

Total thickness unit 13........

12. Phyllite, gray, thin-bedded, slaty; contains thin layers of chert and greenishtan limestone marble containing crinoid fragments, and of chert-pebble conglomerate and sandstone........

Conglomerate: flattened pebbles of chert, phyllite, and quartzite, in matrix of gray schistose sandstone or graywacke.

Phyllite, gray to tan, thin-bedded to fissile; contains interbeds of tan ferruginous limestone that thicken southeastward; in northwestern exposures limestone strata contain crinoid fragments, fusulinids, and pebbles of chert and limestone

Total thickness unit $12 \ldots \ldots . .$.

11. Quartzite, tan, massive; brown quartzitic to micaceous phyllite. . . . . . . . .

10. Quartzite, tan, thick-bedded to massive, very fine grained; grades southeastward into quartzitic and micaceous phyllite........................

9. Phyllite, gray to brown, thin-bedded, slaty, micaceous; contains interbeds of $\tan$ micaceous quartzite and gray chert.

Chert, black, gray, brown; contains a few thin lenses of limestone marble

Phyllite: like that above; contains some tan siliceous (tuffaceous?) shale in southeastern exposures; 0-200-ft-thick lens of white quartzite near base at crest of mountains.

Chert, gray, brown, tan, thin-bedded.

Total thickness unit 9

$2,050 \pm$

500

800

1,500

1,300

200-500

$3,800 \pm$

$0-1,400$ thins and pinches out southeastward_

7. Chert, black to tan, thin-bedded; contains interbedded phyllite layers; grades northwestward into siliceous phyllite

6. Phyllite, gray to black, thin-bedded, slaty, micaceous, brittle, siliceous; contains some thin-bedded quartzite and chert layers.

5. Limestone, marble, dark-greenish-gray, thick-bedded; contains numerous quartz grains, interbedded chert and phyllite; lenses out to northwest; to southeast, marble overlies and underlies thick tongue of dark chert conglomerate like that of unit 3
Garlock Formation of El Paso Mountains-Continued

4. Phyllite: like that of unit 6; in southern foothills upper part includes one or more massive beds as thick as $100 \mathrm{ft}$ of limestone marble similar to that of unit 5. -

3. Chert conglomerate: flat pebbles of chert, few of phyllite and limestone marble, in matrix of gray-black chert

Phyllite: like that of units 6 and 4; thickens to south where it contains 0-100-ft-thick lens of chert conglomerate base

Estimated thickness
$($ feet $)$

$900-1,300$

$200-300$

Total thickness unit 3

2. thins southward

1. Phyllite, dark-gray, thin-bedded, cherty, siliceous to micaceous, schistose; ferruginous, graphitic basal part contains flat pebbles of phyllite(?) and at one place $1 / 4$ mile north of Mesquite Wash contains fragments of Mesquite(?) Schist.

200-400

Approximate exposed thickness of Garlock Formation (including intrusive? andesite) .............

Angular unconformity.

Mesquite Schist.

$\frac{50-200}{200-500}$
$200-1,500$

35,000

AGE

Metasedimentary rocks of western Mojave Desert nearly devoid of diagnostic marine fossils; meager fossil remains found only in Oro Grande, Garlock, and Fairview Valley Formations at a few places.

Age of unfossiliferous unnamed metamorphic rocks in western El Paso Mountains; Precambrian, Paleozoic, or Mesozoic. Precambrian age suggested by similarity of quartzite conglomerate to that in micaceous schist and quartzite of known Precambrian age in Panamint Range about 80 miles northeast (Wright and Troxel, 1954, p. 24, fig. 9).

In Oro Grande Formation, crinoid fragments suggestive of Carboniferous age from limestone marble $31 / 4$, miles northeast of Oro Grande and $2 \frac{2}{3}$ miles northeast of Victorville, reported by Miller (1944, p. 99-100, fig. 6); brachiopod and crinoid debris of Carboniferous(?) age from upper part of limestone marble on Sparkhule Hill, and two poorly preserved brachiopods suggestive of Pennsylvanian age from top of carbonate unit (in W1/2 sec. 25, T. 7 N., R. 6 W.) in southeastern Shadow Mountains, reported by Bowen $(1954$, p. 34$)$. Oro Grande Formation lithologically similar to Furnace Limestone (Vaughn, 1922, p. 344, 352-365, map) in San Bernardino Mountains from which crinoid and other fossil fragments of Carboniferous (Mississipian?) age are reported by Wood. 

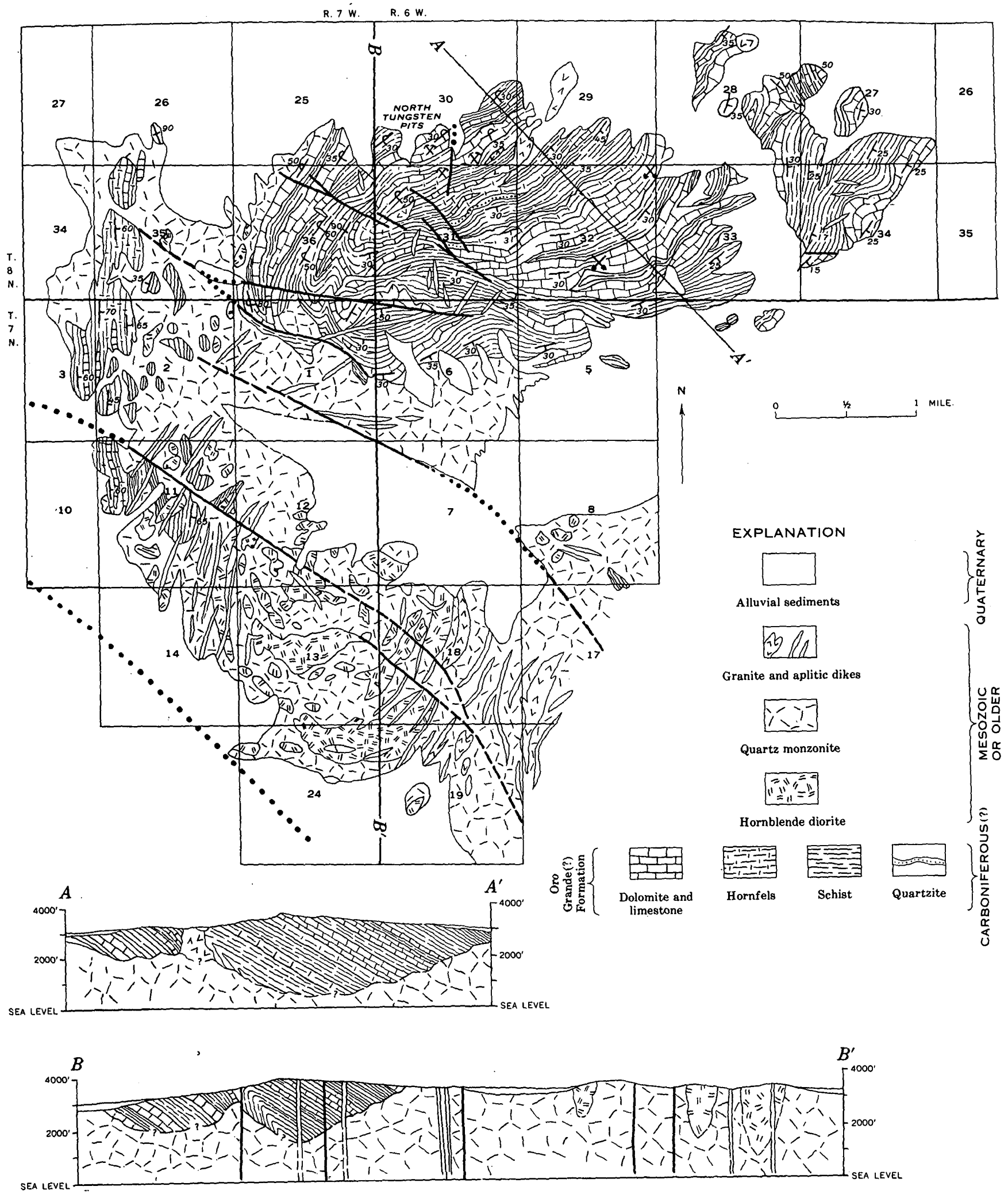

Figure 16.-Geologic map and section of northern Shadow Mountains. 


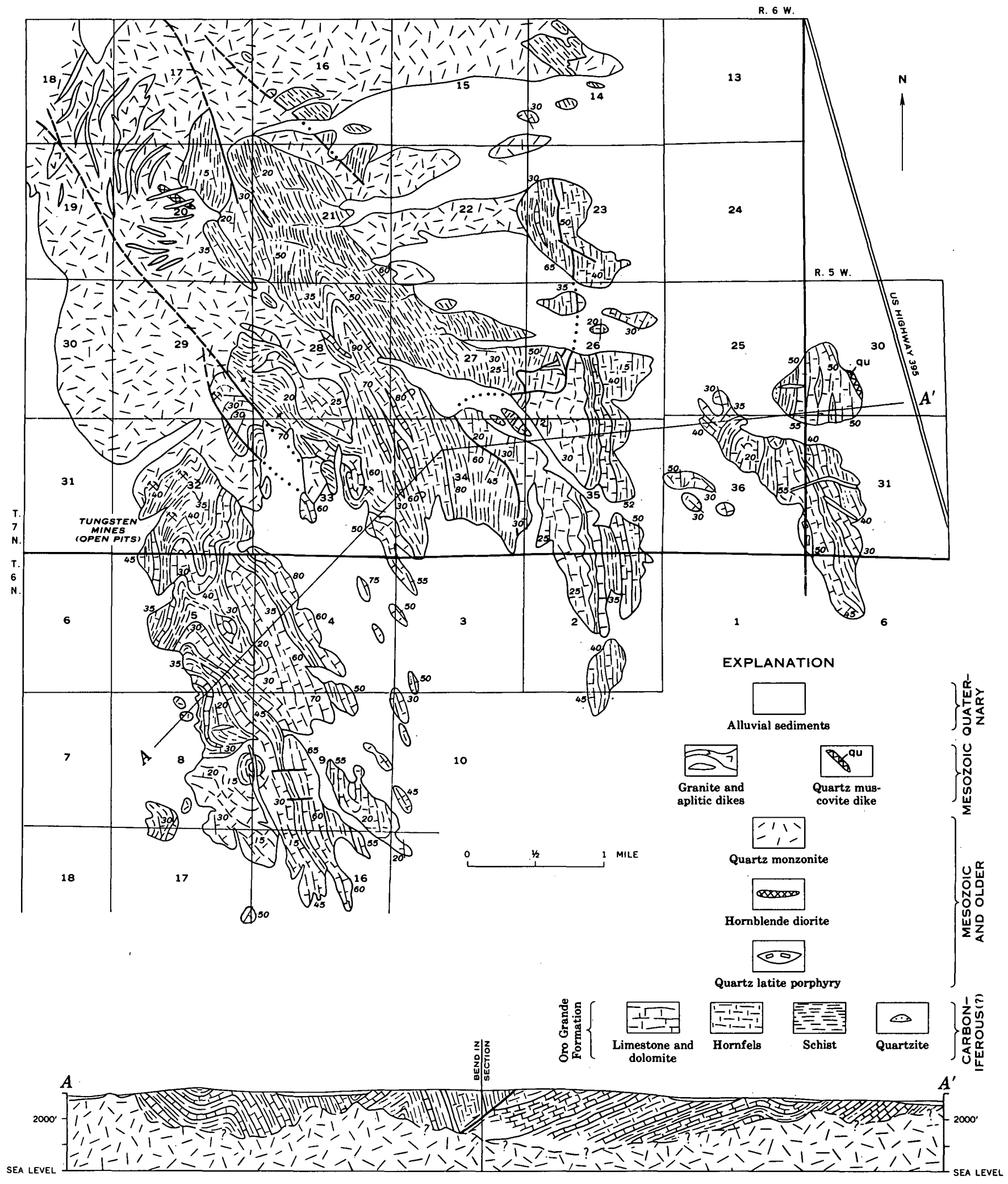

Figure 17.-Geologic map and section of southern Shadow Mountains. 


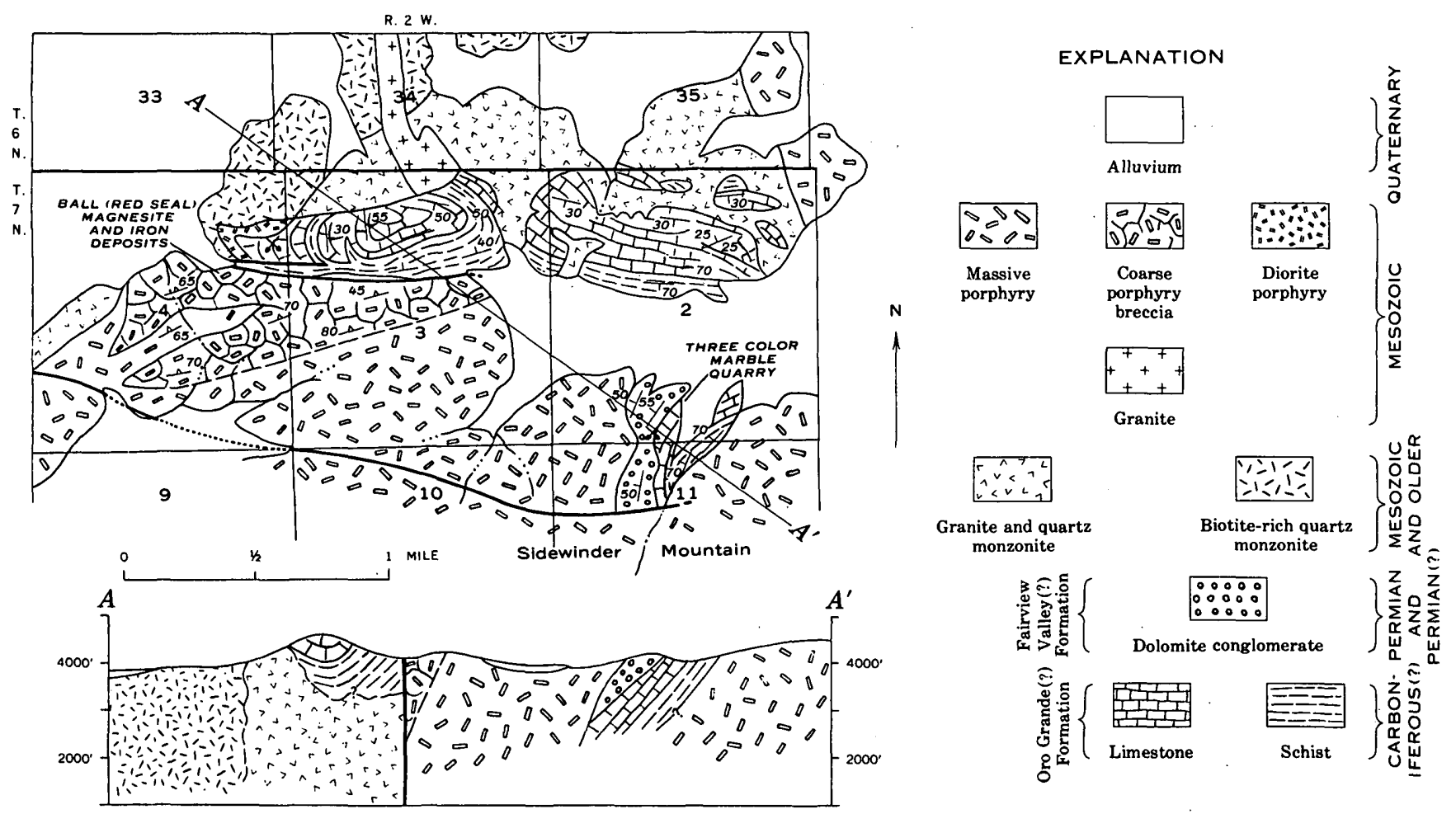

FIgURE 18.-Geologic map and section of northernmost part of Sidewinder Mountain.

ford and Harris (1928, p. 270), and Mississippian fossils found by J. F. Richmond (1960). Foregoing evidence indicates Oro Grande Formation of probable Carboniferous age.

Bean Canyon Formation and other metasedimentary rocks in Tehachapi Mountains and southern Sierra Nevada lithologically similar to each other and to Oro Grande Formation and therefore may be correlative; thus most likely of late Paleozoic (Carboniferous?) age.

In Garlock Formation of El Paso Mountains, crinoid stems and fusulinids found in pebbly impure platy limestone at base of unit 12 near Goler Canyon; fusulinids identified as Schwagerina sp., of Permian age; because of absence of Parafusulina, unit 12 believed to be Lower Permian (C. W. Merriam, in Dibblee, 1952 , p. 19, footnote). No other diagnostic fossils found; crinoid fragments found in units 16-19; units 13-22 probably Permian, possibly in part younger; units 1-11 unfossiliferous, probably pre-Permian but presumably late Paleozoic in age. Upper part of Garlock Formation (units 12-22) probably younger than Oro Grande and Bean Canyon Formations and unnamed metasedimentary rocks.

In Fairview Valley Formation, except for two localities, fossils found only in limestone conglomerate of Black Mountain, and nearly all in limestone clasts; therefore, they only indicate age of source rock of clasts. Fossils collected by Bowen and H. R. Gale at Black Mountain mostly corals, brachiopods, gastropods, fragments of echinoids and crinoids, and few bryozoa, known from rocks of Cambrian to Permian ages, mostly Mississippian to Permian; more common fossils listed by Bowen (1954, p. 42) as follows:

Fossils from limestone conglomerate of Fairview Valley Formation, Black Mountain

[Occurrence: a, abundant; c, common; r, rare]

Name Known age range

Bellerophonids . . . . . . . Ordovician to Permian .. a

Straparoids . . . . ......... Silurian to Jurassic . . . . a

Raphistomids(?) ......... Ordovician to Silurian... a

Chonetes granulifera Pennsylvanian to Per- c

(Owen).

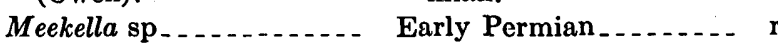

Heritchia sp. (Waageno- Permian_.............. a phyllum).

Polypora sp...........

Meekopora sp.............

Composita sp

Late Paleozoic _........ c

Mississippian to Penn- $r$ sylvanian.

Mississippian to Per- a mian.

Aulosteges sp.(?) Omphalotrochus whitneyi... Omphalotrochus obtusispira.

Echinocrinus sp

Permian............. $\mathbf{a}$

Early Permian........ c

Permian............. $r$

Archeocidaris sp........
Mississippian to Penn- a sylvanian.

Late Paleozoic . . . . . . . . c
Occurrence

and

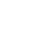

.

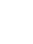

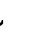

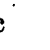

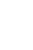

and




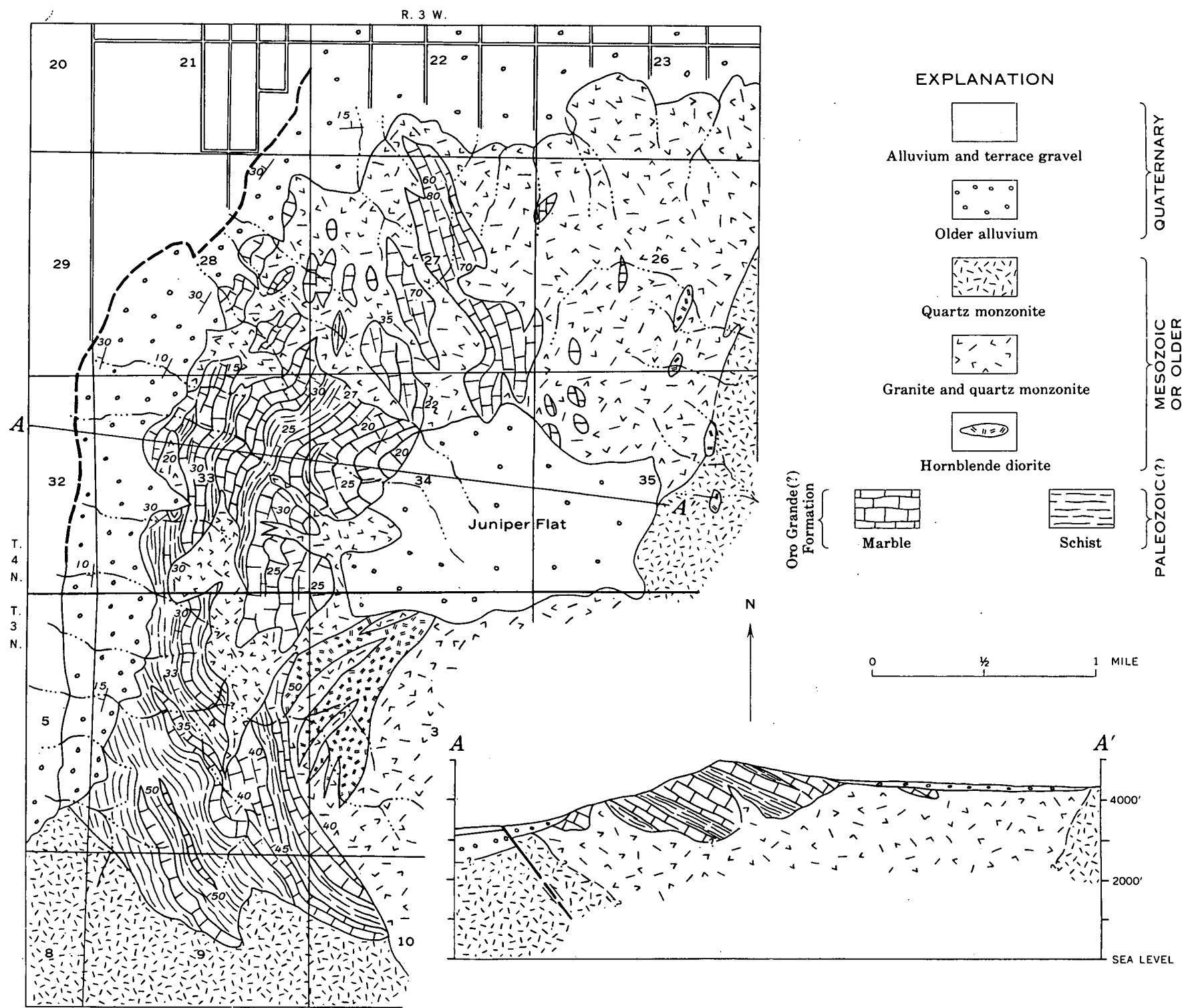

Figure 19.-Geologic map and section of Juniper Flat area, northwestern San Bernardino Mountains.

Fossils reported by Bowen (1954, p. 41) from two localities less than a mile west of Black Mountain in thin conglomerate lenses in hornfels of lower part of Fairview Valley Formation included only small gastropods and Syringopora (?).

Fossils from limestone clasts in conglomerate of Black Mountain indicate Fairview Valley Formation may be Permian or younger, possibly Mesozoic, but it is older than plutonic and hypabyssal rocks of Mesozoic age that intrude it. Fairview Valley Formation either correlative with or younger than upper part of Garlock Formation which it closely resembles lithologically.

\section{METAVOLCANIC AND HYPABYSSAL ROCKS HODGE VOLCANIC FORMATION}

Sequence of metavolcanic rocks exposed between Iron Mountain and Mojave River near Hodge (pl. 1) ; described and mapped as Hodge Volcanic Formation by Bowen (1954, p. 34-36, pl. 1). Plutonic as well as volcanic assemblage described and mapped by Miller (1944, p. 79-98) as Hodge Complex.

Hodge Volcanic Formation composed of at least four rock types: quartz latite-dacite porphyry, schistose quartz latite, sericite or muscovite schist, and quartzite (fig. 7). 


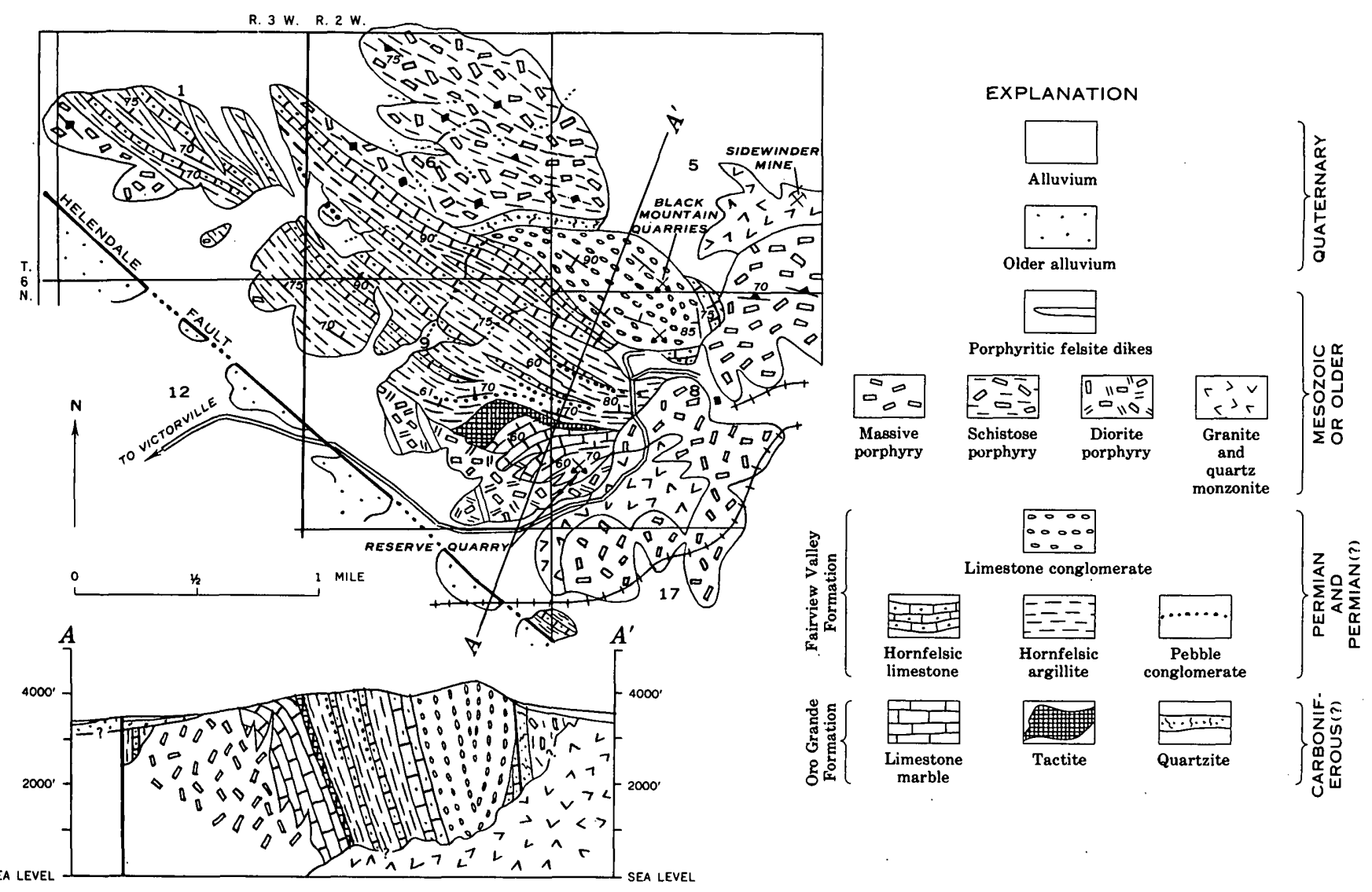

Figure 20.-Geologic map and section of Black Mountain area near Sidewinder Mountain.

Quartz latite-dacite porphyry massive, nonfoliated, dark-brownish gray; composed, in order of decreasing abundance, of subrounded, partly resorbed phenocrysts 1-3 $\mathrm{mm}$ in size of plagioclase (oligoclase), orthoclase, quartz, and biotite, that make up 20-45 percent of rock mass, in aphanitic groundmass containing iron oxides.

Schistose quartz latite dark-greenish, purplish to brownish gray. Sericite, muscovite, and biotite present in variable amounts in groundmass.

Sericite or muscovite schist a heterogeneous unit ranging from dark schistose quartz latite to lightcolored sericite or muscovite schists. Tan to creamwhite schists, very highly foliated and fine grained, composed almost entirely of sericite, muscovite, and finely divided quartz.

Quartzite light tan, massive to faintly bedded, fine grained; composed entirely of quartz; slightly to severely brecciated but recemented by limonite and hematite. Rock commonly stained yellowish to reddish brown. Occurs as lenses in sericite or muscovite schist sometimes as much as 50 feet wide and 2,000 feet long.

Formation probably metamorphosed from sequence of extrusive lava flows and pyroclastic rocks, possibly from some intrusive rocks. Age mainly Mesozoic, and as old as Permian(?), but probably younger than Oro Grande Formation.

\section{PORPHYRY COMPLEX}

Porphyry complex of area east of Mojave River.Porphyritic rocks of mainly latite or andesite composition extensively exposed from Mojave River eastward to and beyond east border to mapped area ( $\mathrm{pl}$. 1). Rocks described and mapped by Miller (1944, p. 100-102, pl. 5) and called Sidewinder Valley Metavolcanics (late Paleozoic). Called Sidewinder Volcanic Series (Triassic?) by Bowen (1954, p. 42-43, 68-72, pl. 1), but intrusive rocks near Stoddard Well mapped by him as quartz monzonite porphyry of Jurassic to Cretaceous age. Beyond east border of mapped area called Ord Mountain Group (Triassic) by Gardner (1940, p. 266-270, pl. 1). Because of complex and controversial field relations, lithologic terms only, rather than formational names, applied to these igneous rocks in this report.

Porphyry complex consists of three lithologic units differentiated and described on quadrangle maps 


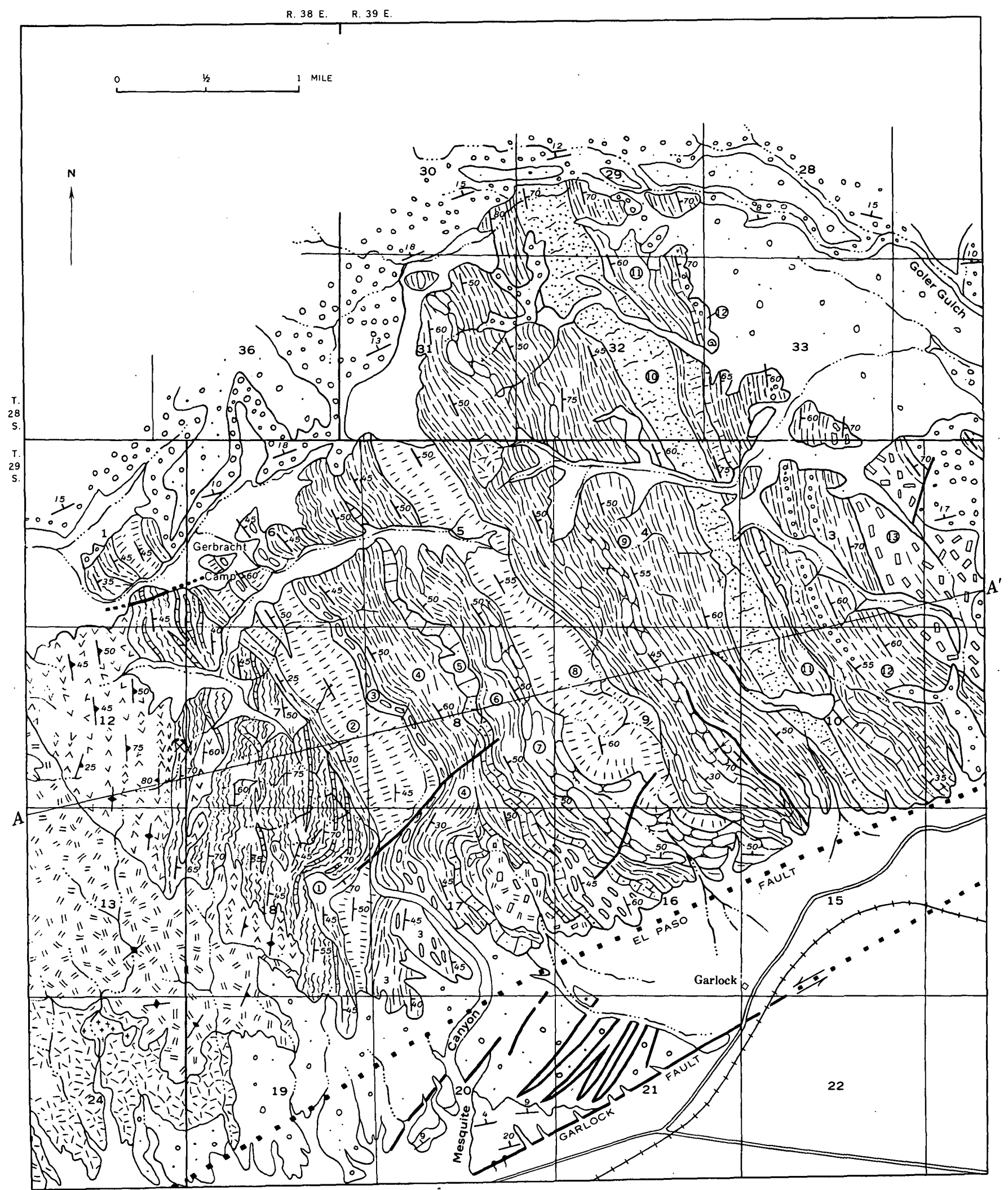

Figure 21.-Geologic map of central 


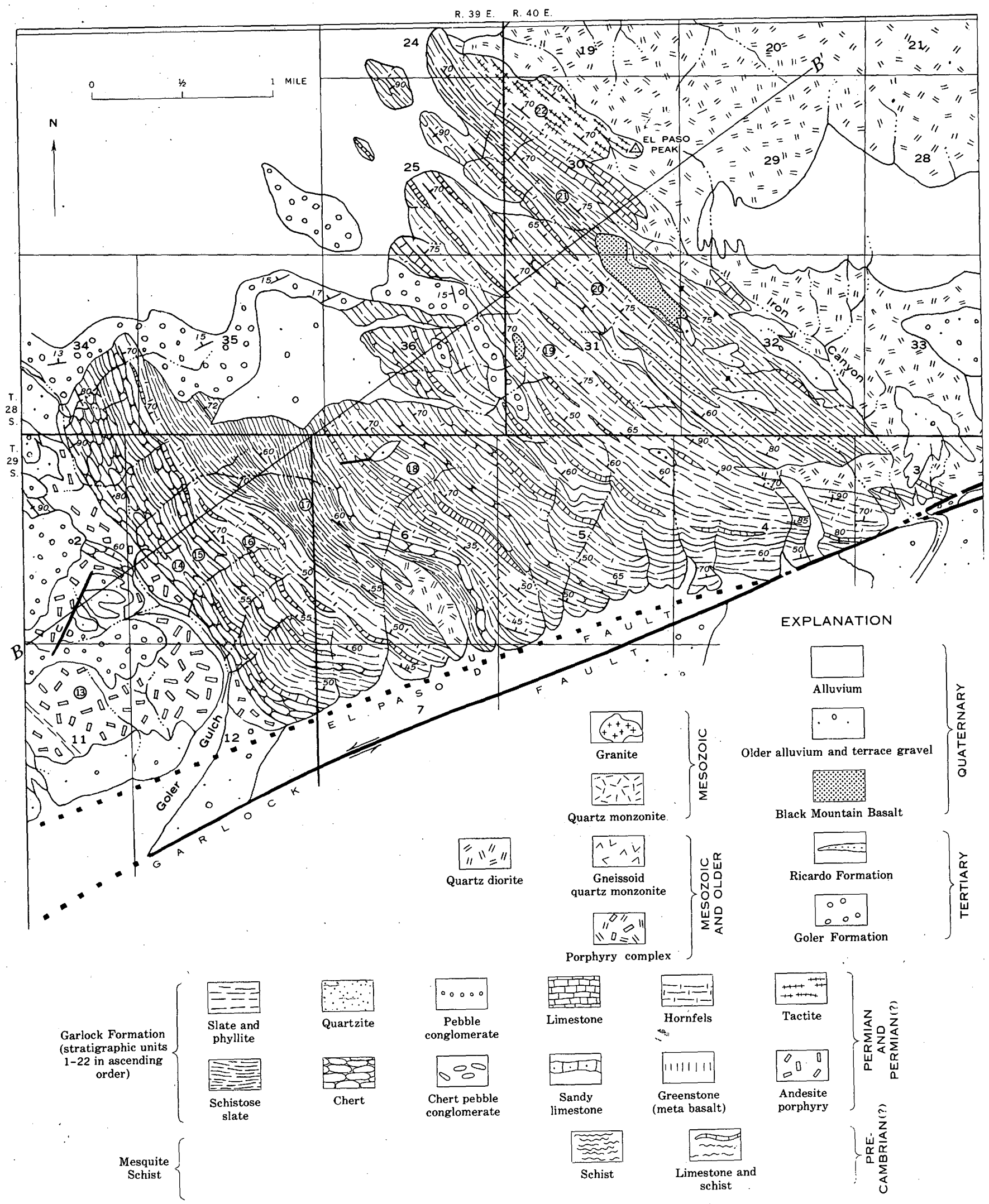

and eastern El Paso Mountains. 


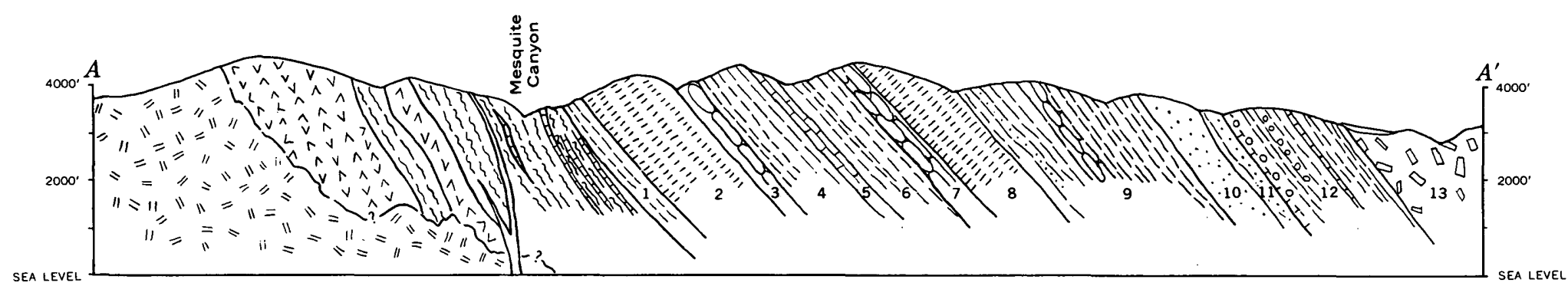

FIGURE 22.-Sections of El Paso Mountains. Locations of sections are shown on figure 21. Numbers refer to units of Garlock Formation. 
(Dibblee, 1960a, 1960e, 1960g) as porphyry, porphyritic felsite, and tourmaline-quartz-muscovite rock.

\section{PORPHXRY}

Porphyry ranges from latite and andesite (predominant) to quartz latite and dacite (subordinate); phenocrysts constitute $10-50$ percent of rock, range from 1-4 $\mathrm{mm}$ in diameter. Groundmass medium to dark gray; weathers brownish gray; aphanitic to fine grained. Phenocrysts generally subrounded, partly resorbed; composed of plagioclase (sodic andesine), orthoclase, biotite, hornblende, and quartz, in order of decreasing abundance, some or all of last four not everywhere present; biotite and hornblende partly or wholly replaced by magnetite and chlorite in many rocks. Groundmass probably composed of same minerals present as phenocrysts, as well as quartz, sphene, magnetite, epidote, and chlorite. Remnants of shards(?) and other minute fragments visible in groundmass in many thin sections suggest rock may be in part a metatúff (A. O. Woodford, oral commun., 1959). Crystalline epidote commonly present as veinlets, fracture coatings, and small rosettes within rock.

Porphyry composed of following lithologic facies, all gradational into each other, as shown on quadrangle geologic maps (Dibblee, 1960a, e, g): (1) massive porphyry, (2) diorite porphyry, (3) chloritized porphyry, (4) schistose porphyry, (5) fine porphyry breccia, (6) coarse porphyry breccia, (7) metatuff, and (8) felsite agglomerate.

Massive porphyry.-Massive, most widespread facies of porphyry; forms large masses and some narrow dikes; contains relict spherulites as large as half an inch in diameter.

Diorite porphyry.-Exposed 1 mile south of Black Mountain and 3 miles west of Stoddard Well and in hills just north of Stoddard Well (Dibblee, 1960d). Dark-gray dioritic facies of porphyry; phenocrysts consist only of plagioclase and hornblende; groundmass fine to medium grained, composed of plagioclase, orthoclase, hornblende, and magnetite.

Chloritized porphyry.-Exposed mostly at Stoddard Mountain southwest of Stoddard Well (fig. 23) and on the mountain 3 miles southwest, and on Silver Mountain (Dibblee, 1960g). Dark-gray to nearly black schistose, somewhat mafic facies; contains ferromagnesian minerals largely altered to chlorite and biotite, and indistinct plagioclase phenocrysts.

Schistose porphyry.-Facies exposed along western margin of the hills within 3 miles southeast of Helendale (Dibblee, $1960 \mathrm{~g}$ ); in hill 1 mile west of Sidewinder mine (fig. 20) and northwestward for 4 miles (Dibblee, 1960e); on west slope of Stoddard Mountain and on Stoddard Ridge (fig. 23). A light-colored facies containing indistinct phenocrysts; groundmass weakly to intensely sericitized; locally chloritized. In places altered to sericite-quartz schist, in others almost completely silicified to rock resembling quartzite.

Fine porphyry breccia.-Exposed in hills 1-2 miles southeast of Helendale, on low ridge west-southwest of Stoddard Mountain (Dibblee, 1960e, g), on Stoddard Ridge (fig. 23), and near base of Sidewinder Mountain (Dibblee, 1960e). Porphyry has sparse to numerous angular fragments of tan, brown, or gray felsite about an inch or less in diameter; fragments alined in places to suggest volcanic bedding or flow structure; locally somewhat schistose.

Coarse porphyry breccia.-Facies present as easttrending strip on Sidewinder Mountain (fig. 18) ; dark gray, composed of unsorted angular to subrounded fragments of porphyry from less than 1 inch to several feet in diameter; matrix schistose; some lenses of chert and silicified breccia as much as 10 feet thick.

Metatuff.-Exposed in Silver Mountain area (Dibblee, $1960 \mathrm{~g}), 2$ miles east and 2 miles northeast of Sparkhule Mountain (figs. 14, 15). Massive white to gray-white hard to chalky microgranular rock presumably composed mainly of quartz and sericite, possibly some feldspar; rock closely fractured and iron stained on fracture surfaces. Some layers are breccias with fragments of felsite; others are altered to powdery white aggregate of sericite and quartz.

Felsite agglomerate.-Facies exposed as lenticular body 4 miles northeast of Oro Grande (figs. 14, 15). Poorly bedded or nonbedded accumulation of angular to subrounded fragments as much as 4 inches in length in gray-brown fine-grained matrix; most fragments gray-white to light-gray felsite; locally in basal part fragments light-gray quartzite; matrix volcanic to arkosic, in places replaced by epidote.

\section{PORPHYRITIC FELSITE}

Exposed in hills northwest of Sidewinder Valley, on Stoddard Ridge, at northeast base of Sidewinder Mountain (Dibblee, 1960e), and in hills north of Stoddard Ridge. Quartz latite tơ rhyolite in composition, tan to pale pink, massive felsitic to porphyritic having aphanitic to finely aplitic texture. Phenocrysts as much as $2 \mathrm{~mm}$ in diameter, form 10 percent or less of rock mass; most are plagioclase (oligoclaseandesine), others are orthoclase, quartz, and biotite. Groundmass same minerals as phenocrysts, plus hematite, magnetite, sphene, apatite, and zircon. Piedmontite reported by Bowen (1954, p. 51) may impart pink color to rocks on Stoddard Ridge and Sidewinder Mountain. Rocks generally unmetamorphosed. 


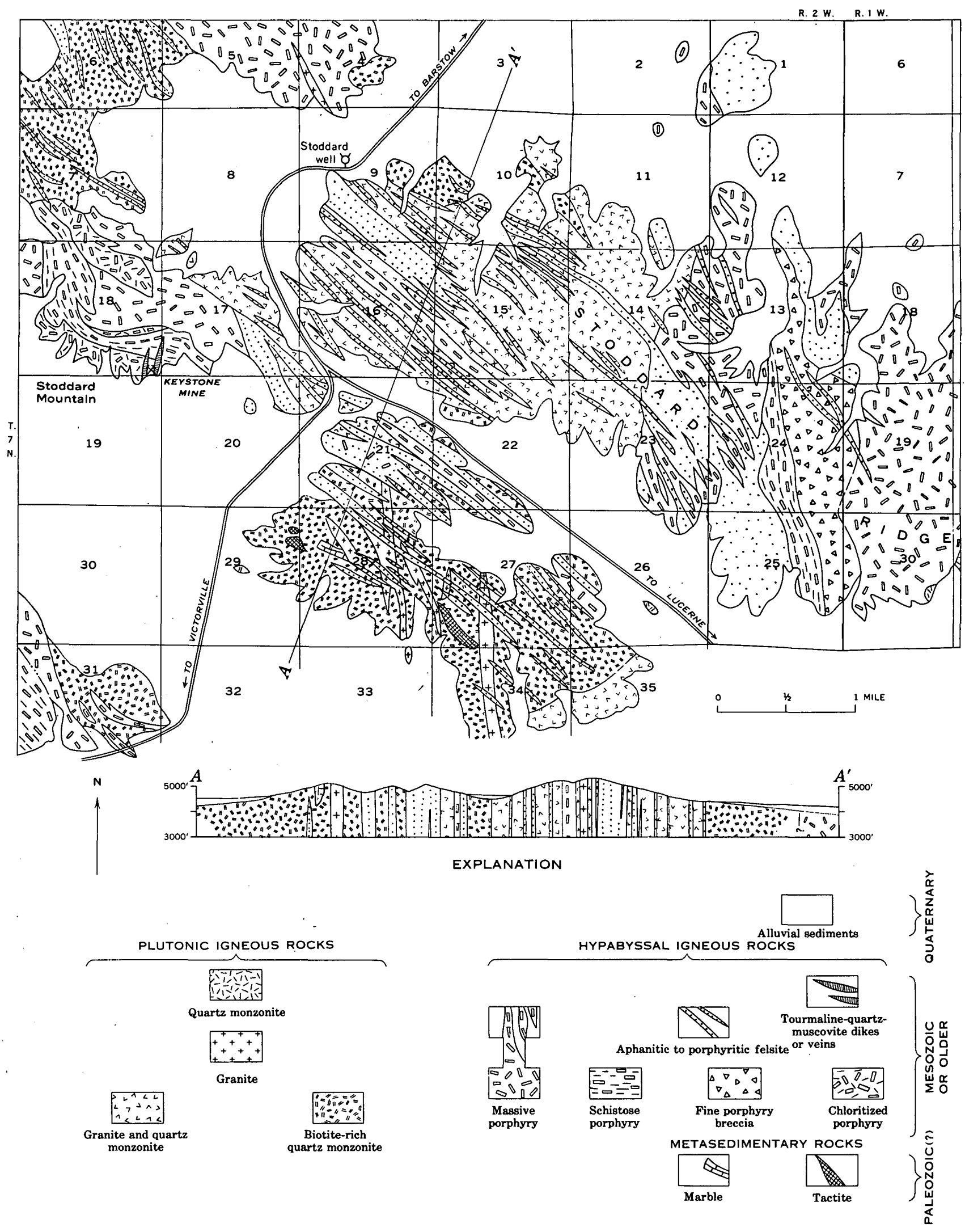

Figure 23.-Geologic map and section of Stoddard well area. 
TOURMALINE-QUARTZ-MUSCOVITE ROCK

Described as "tourmalinized quartz porphyry" by Bowen (1954, figs. 28, 29). Crops out 2 miles southwest of Stoddard Well as two north-northeast-trending dikes as much as 50 feet wide (fig. 23). Rock gray white, hard; composed of fine-grained aggregate of quartz and muscovite with numerous rosettes 1-2 $\mathrm{mm}$ in diameter of finely crystalline blue-black tourmaline; rosettes contain limonite, probable alteration of pyrite, imparting brown stain to rock.

Porphyry complex of Boron area.-Exposed in low hills just north of Boron (fig. 46). Gray-white massive porphyry of quartz latite composition containing subrounded phenocrysts as large as $5 \mathrm{~mm}$ in diameter of quartz and feldspar; phenocrysts make up 10-15 percent of rock mass in a fine-grained aplitic groundmass of plagioclase (oligoclase), potassic feldspar, quartz, muscovite, biotite, and hematite. Rock commonly iron stained on fracture surfaces.

Porphyry complex of El Paso Mountains.-Exposed between Iron and Goler Canyons in the El Paso Mountains (fig. 21). Porphyry dark gray; massive, except at southwest margin of outcrop where it is locally brecciated and crudely schistose. Andesite composition having phenocrysts of plagioclase and altered hornblende in finely crystalline groundmass. Phenocrysts make up 20-30 percent of rock mass.

\section{FIELD RGLATIONS, ORIGIN AND AGE}

In areas east of Mojave River most facies of porphyry complex are of hypabyssal origin and are intrusive into Oro Grande and Fairview Valley Formations and into older plutonic rocks of Mesozoic age; all facies are intruded by quartz monzonite of Cretaceous age. Extrusive facies apparently overlies Oro Grande Formation east of Quartzite Mountain (figs. 14, 15). Porphyry complex is therefore mainly of Mesozoic age, possibly as old as Permian, and as young as Cretaceous.

Dikes and most large bodies of massive porphyry intrusive, but some large masses may be extrusive. Diorite porphyry intrusive; metatuff and felsite agglomerate probably of pyroclastic origin; other facies of porphyry either intrusive or extrusive or both. Porphyritic felsite of hypabyssal intrusive origin.

In Boron area, porphyry complex forms small masses engulfed in Mesozoic quartz monzonite. In El Paso Mountains, porphyry complex forms sill-like mass emplaced in Garlock Formation, but may be in part extrusive.

\section{QUARTZ LATITE FELSITE}

Quartz latite felsite of Victorville area.-Felsitic rock exposed 3 miles northeast of Victorville in north- trending strip (pl. 1) described and mapped as mixed Oro Grande and Sidewinder Valley by Miller (1944, p. 102, pl. v) ; included in Oro Grande Series by Bowen $(1954, \mathrm{pl} .1)$; differentiated from it by Dibblee $(1960 \mathrm{~g})$. Forms pendant in plutonic rocks.

Rock dark gray, massive to slightly schistose, microcrystalline; composed of potassic feldspar, plagioclase (oligoclase-andesine), quartz, biotite, hornblende, and hematite; in places contains very small phenocrysts of plagioclase.

Quartz latite felsite of Kramer Hills. - Felsite (mapped as hornfels by Dibblee, 1960d; included in Sidewinder Volcanic Series by Bowen, 1954, pl. 1) forms northeast-trending pendant 1 mile wide and 4 miles long on quartz monzonite in eastern Kramer Hills (pl. 1).

Felsite light gray; weathers brown; massive to faintly laminated, very fine grained; composed of quartz, potassic feldspar, calcic plagioclase (labradorite and bytownite), epidote, biotite, hematite, and magnetite, in order of decreasing abundance. Age presumably Mesozoic.

\section{RHYOLITE APLITE}

Rhyolite aplite of western El Paso Mountains.Exposed at and near lower Redrock Canyon at southwest end of El Paso Mountains (pl. 1, fig. 63) ; originally mapped as granophyre (Dibblee, 1952, pl. 1, p. 33-34), intrusive into quartzite conglomerate and hornfels; rock light gray; weathers buff; very hard, massive, very fine grained; contains scattered small round phenocrysts of quartz and feldspar (less than $2 \mathrm{~mm}$ in diameter). Age presumably Mesozoic.

\section{HORNBLENDE SCHIST AND GREENSTONE}

Hornblende schist of Kramer Hills.-Exposed on north flank of Kramer Hills east of U.S. Highway 395 as pendants in quartz monzonite. Rock gray black, massive to indistinctly foliated, fine to medium grained; composed of about 65 percent hornblende, 25 percent plagioclase (andesine), and 10 percent orthoclase, quartz, and iron oxides; weathered and weakly coherent. Age presumably Mesozoic.

Hornblende schist and greenstone near Mirage Lake. -Exposed on a hill 2 miles southwest of Mirage Lake (fig. 24).

Greenstone dark olive green, massive, fine grained; composed of antigorite or serpentine containing specks of magnetite; in places abundant veinlets of calcite, and some pseudomorphs of antigorite after coarsely radial crystalline actinolite or tremolite.

Hornblende schist (or gneiss) gray black, medium to fine grained, homogeneous but with crude foliation; 


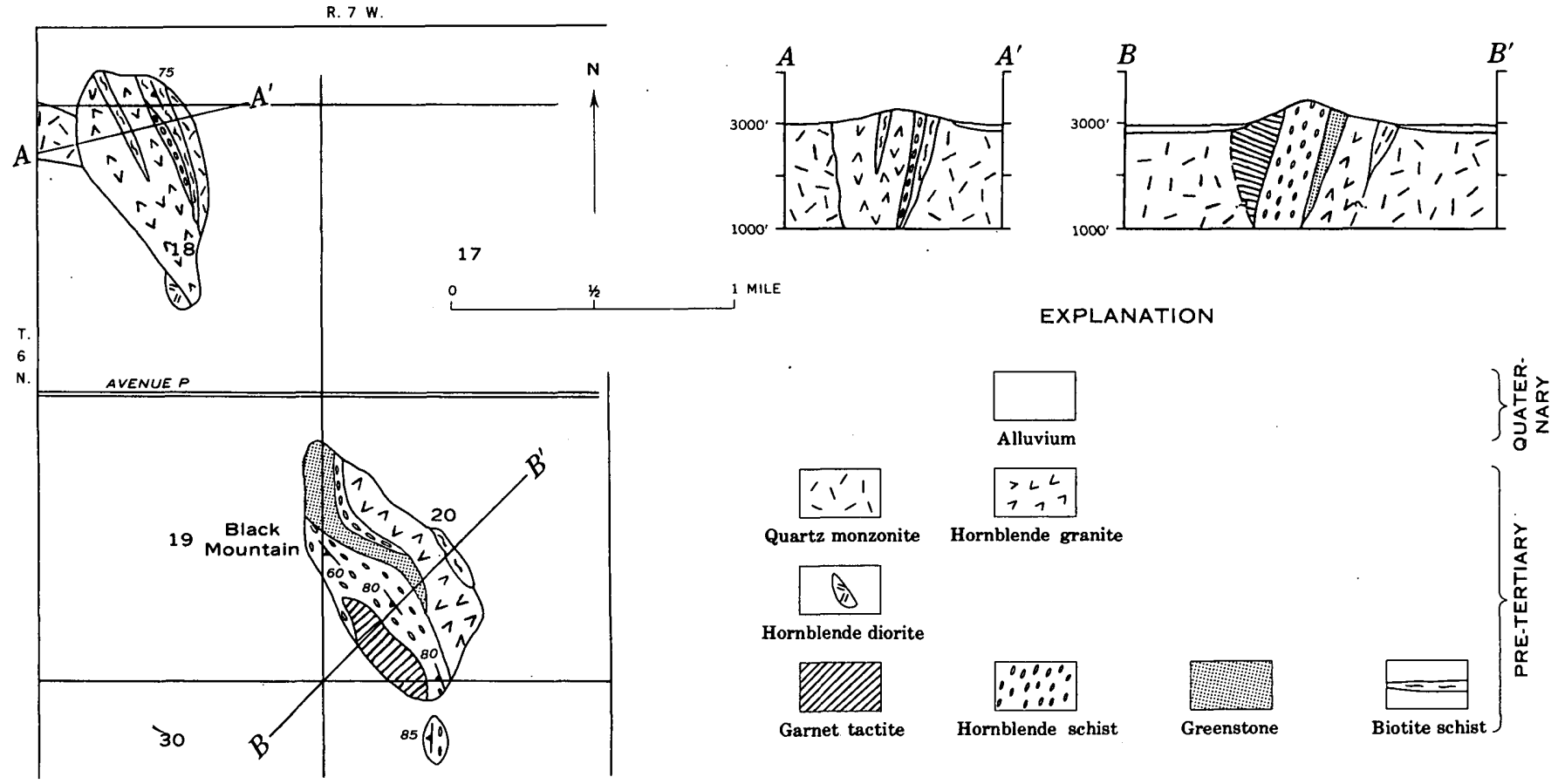

Frgure 24.-Geologic map and section of hills southwest of Mirage Lake.

composed predominantly of hornblende, much plagioclase (andesine), and some iron oxides.

\section{PLUTONIC ROCKS}

Plutonic igneous rocks constitute the major part of the exposed pre-Tertiary crystalline complex in the Mojave block. They crop out in the Sierra Nevada, and in the western and central parts of the Mojave Desert as far south as the San Bernardino and San Gabriel Mountains.

The rocks are generally of medium-grained $(3 \mathrm{~mm}$ average grain size) granitoid texture, and range in composition from granite to hornblende diorite or gabbro. Predominant plutonic types in the Mojave block are light-colored massive homogeneous quartz monzonites.

The following lithologic units were recognized: (1) hornblende diorite and gabbro, (2) quartz diorite, (3) ferruginous syenite, (4) aplitic quartz monzonite, (5) gneissoid quartz monzonite, (6) biotite-rich quartz monzonite, (7) granite and quartz monzonite, (8) quartz monzonite, and (9) granite. Age relations of the first seven units are undetermined, but presumably they are contemporaneous (Mesozoic or older?). The last two units are younger and are of Mesozoic age.

\section{HORNBLENDE DIORITE AND GABBRO}

Rock exposed in Gamble Spring Canyon, Tehachapi Mountains (fig. 12), in hills northwest of Barstow (fig. 5), at Iron Mountain (fig. 7), in central part of
Shadow Mountains and Bell Mountain, in San Gabriel Mountains, south of Palmdale and Little Rock, and in northwestern San Bernardino Mountains (fig. 19).

Rock dark gray to black, medium to coarsely crystalline, nongneissoid; composed mainly of black hornblende and white to light-gray plagioclase. Hornblende makes up 40-80 percent of rock; forms stubby to prismatic anhedra as much as 3 inches long; plagioclase fills spaces between hornblende anhedra and ranges from calcic andesine to labradorite; consequently rock ranges from diorite to gabbro. Biotite, diopside, magnetite, apatite, and sphene commonly present in small amounts as primary minerals. Secondary minerals include green epidote, either as clusters of grains or as finely crystalline veinlets, clinozoisite, chlorite, and iron oxides.

At Iron Mountain, rock mainly hornblende gabbro; feldspar gray labradorite (Bowen, 1954, p. 54-58). At Bell Mountain, rock highly mafic hornblendite; hornblende as much as 80 percent, remainder plagioclase (labradorite), olivine (in part altered to serpentine and talc), diopside (in part altered to chlorite), magnetite, and epidote.

In most places hornblende diorite and gabbro form ovate or elongate masses engulfed in and intruded by quartz monzonite (fig. 16), therefore older than quartz monzonite. Other masses associated with metasedimentary and gneissic rocks, commonly along contacts with quartz monzonite, elongate parallel to contacts 
and to foliation of metamorphic rocks (pl. 1, figs. 5, $7,12)$. These relations suggest that diorite and gabbro formed partly by metasomatism of metamorphic rocks during invasion of quartz monzonite in Mesozoic time.

\section{QUARTZ · DIORITE}

Exposed extensively in western San Bernardino, San Gabriel, Tehachapi, and El Paso Mountains, and as small scattered masses in eastern parts of desert area.

Grades from gray-white granodiorite composed mainly of plagioclase and quartz, minor but variable amounts of potassic feldspar, biotite, and hornblende, through quartz diorite, to medium-gray diorite composed mainly of plagioclase and hornblende. Quartz makes up as much as 30 percent of rock. Plagioclase (mainly andesine, less commonly oligoclase) makes up about half of rock. Potassic feldspar (microcline or orthoclase) seldom exceeds 10 percent of rock. Biotite also seldom exceeds 10 percent. Hornblende most abundant in diorite facies and in some places as high as 40 percent of rock. Accessory minerals, less than 2 percent of rock, are magnetite, sphene, apatite, and zircon. Secondary minerals, mostly in dioritic facies, are iron oxides (after hornblende and biotite), chlorite (after biotite), epidote (after hornblende), and sericite and kaolinite (after feldspars), and veinlets of epidote.

Quartz diorite generally gray and faintly to moderately gneissoid, especially in San Bernardino and San Gabriel Mountains and Tehachapi Mountains northwest of Garlock fault zone. However in Tehachapi Mountains southeast of Garlock fault zone and in eastern El Paso Mountains, quartz diorite graywhite, nongneissoid, in part of granodiorite composition, and physically indistinguishable from the quartz monzonite.

Gneissoid quartz diorite younger than gneissic rocks of Precambrian(?) age which it intruded or from which it recrystallized. In area where it intrudes late Paleozoic metasedimentary rocks, must be post-late Paleozoic. Nongneissoid facies either older than, or contemporaneous with, quartz monzonite of Mesozoic age. In places where intruded by quartz monzonite, certainly older.

\section{FERRUGINOUS SYENITE}

Exposed in mountains southwest of Palmdale as mile-wide strip extending southwest from San Andreas fault (pl. 1); mapped and described as syenite and alkali granite by Simpson (1934, pl. 5, p. 385).

Rock light brown to light gray, but stained brown by iron oxides where weathered; nongneissoid, medium grained, equigranular. Composed of 50-65 percent alkali feldspar (mainly microperthite, also microcline and albite), 11-39 percent plagioclase (oligoclase), as much as 12 percent quartz, total of 7-9 percent hornblende, biotite, magnetite, hematite, and limonite, and less than a total of 1 percent apatite, zircon, and epidote. A few lenticular zones as much as 50 feet wide and several thousand feet long of dark-gray or brown syenite, rich in iron oxides.

Ferruginous syenite much older than the Vasquez Formation of Tertiary age that unconformably overlies it; may be same age as Mesozoic or older aplitic quartz monzonite into which it grades.

\section{APLITIC QUARTZ MONZONITE}

Crops out southwest of Palmdale, southwest of San Andreas fault zone, as a mile-wide strip trending north of east (pl. 1) ; mapped as monzonite aplite and quartz diorite by Simpson (1934, p. 384-385, pl. 5).

Rock nearly white; weathers light tan; massive to gneissoid; ranges from fine-grained aplitic to mediumgrained granitoid in texture. Contains many scattered elongate inclusions of biotite-rich banded gneiss. Composed mainly of quartz, alkali feldspar (microclineperthite), and plagioclase (oligoclase) in about equal proportions, and total of less than 10 percent of biotite, muscovite, hornblende, iron oxides, apatite, and zircon.

Aplitic quartz monzonite younger than the gneissic rocks of probable Precambrian(?) age that it either intrudes or was recrystallized from, and probably also younger than Pelona Schist. Much older than Tertiary Vasquez Formation that overlies it unconformably; probably emplaced or formed in Mesozoic time or earlier.

\section{GNEISSOID QUARTZ MONZONITE}

Crops out in two half-mile-wide strips, one east of Redrock Canyon and the other west of Mesquite Canyon (figs. 21, 22) ; formerly mapped as foliated granite (Dibblee, 1952, pl. 1, p. 34-35).

Gray-white fine- to medium-grained gneissoid rock, about one-third quartz, two-thirds feldspar; a small percentage of biotite, muscovite, or sericite. Micas occur as finely divided parallel flakes in parallel clusters or streaks that give rock a gneissoid structure. Potassic feldspar (orthoclase or microcline) and sodic plagioclase (oligoclase) in about equal proportions in western exposure, plagioclase predominant in eastern exposure.

In Mesquite Canyon area, rock in part is mylonitic, especially along contact with Mesquite Schist to east, and most of feldspar is sodic plagioclase.

Gneissoid quartz monzonite younger than Mesquite Schist of Precambrian(?) age from which it may 
have recrystallized or which it may have intruded; older than Mesozoic quartz diorite that intrudes it.

\section{BIOTITE-RICH QUARTZ MONZONITE}

Exposed in vicinity of Stoddard Well (fig. 23). Rock light to dark gray, somewhat mottled, nongneissoid, granitoid. Composed mostly of quartz, potassic feldspar (orthoclase and microcline), plagioclase (oligoclase), and biotite; less than 2 percent accessories (sphene, apatite, and magnetite). Plagioclase predominates slightly over potassic feldspar; biotite forms 5-20 percent of rock as minute black flakes irregularly distributed as clusters producing dark mottlings; in places rock contains large but indistinct phenocrysts of pinkish orthoclase; veinlets and disseminated grains of epidote locally common.

Biotite-rich quartz monzonite intruded by porphyry complex of Mesozoic age, therefore age Mesozoic or older.

\section{GRANITE AND QUARTZ MONZONITE}

Rock unit mapped as granite and quartz monzonite (Dibblee, 1960e) exposed in several areas east of upper Mojave River, mostly in Granite Mountains, and northward to Stoddard Well and Silver Mountain, in vicinity of Sidewinder Mountain, and in the low hills northeast of Sidewinder Valley.

Unit gray white, granitoid, mostly nongneissoid, equigranular, medium grained; weathers grayish to yellowish buff; composed mostly of quartz, potassic feldspar (orthoclase or microcline), and plagioclase (oligoclase) with slight predominance of potassic feldspar; very minor amounts of biotite, muscovite, and such accessories as sphene, apatite, and magnetite, and in places a little hornblende. Feldspars white to grayish white; biotite, which rarely exceeds 4 percent of rock in form of small scattered flakes, commonly leached pale brown, and may be partly or wholly altered to limonite which forms a brown stain. Rock strongly coherent but closely jointed; tends to form jagged, much-broken outcrops.

Local facies of granite and quartz monzonite unit are: (1) A somewhat gneissoid facies, resulting from subparallel orientation of hornblende anhedra and biotite flakes; exposed in extreme southwestern part of the Granite Mountains. (2) A medium- to coarsegrained porphyritic facies containing large scattered rectangular phenocrysts of orthoclase as long as 2 centimeters; exposed in gap between two main parts of Granite Mountains. (3) A fine-grained aplitic facies containing small feldspar phenocrysts; exposed in extreme northern Granite Mountains, southern part of Sidewinder Mountain, Stoddard Ridge, and northward and westward nearly to Helendale fault. medium-grained facies approaching syenite and monzonite in composition; made up almost entirely of conspicuous rectangular grains of feldspar and very little quartz; exposed just north of Sidewinder Mountain and in the area about 5 miles southeast of Helendale.

In Granite Mountains and north of Sidewinder Mountain, granite and quartz monzonite unit engulfs pendants of Oro Grande Formation, is therefore younger than that formation. In vicinity of Sidewinder Mountain, aplitic facies apparently gradational into large masses of porphyry complex; if so, presumably same age. However, near Stoddard Well and in Silver Mountain may be intrusive into large masses of porphyry complex but intruded by dikes of that rock. Intruded by quartz monzonite of Cretaceous age. Therefore, age of granite and quartz monzonite Mesozoic, probably Jurassic or Early Cretaceous.

\section{QUARTZ MONZONITE}

Extensively exposed in western Mojave Desert between San Andreas and Garlock faults, locally exposed north of Garlock fault (fig. 70) and south of San Andreas fault (pl. 1).

In Randsburg mining district mapped as Atolia Quartz monzonite by Hulin (1925, pl. 1, p. 33-39); in Victorville area as Victorville quartz monzonite by Miller (1944, pl. V, p. 105-106), Bowen (1954, pl. 1, p. 65-68); at Liebre Mountain as Liebre quartz monzonite by Crowell (1952, pl. 1, p. 8-11) ; in Valyermo area as Holcomb quartz monzonite by Noble (1954a).

Rock gray white medium grained nongneissoid granitoid, remarkably uniform in physical character throughout its great areal extent. Composed essentially of quartz, potassic feldspar (microcline or orthoclase), and plagioclase (oligoclase or andesine) in nearly equal proportions, but with slight predominance of plagioclase in some places, of potassic feldspar in few others; contains small percentage of biotite, usually as scattered black euhedral plates; total of less than 2 percent accessories (hornblende, iron oxides, sphene, apatite, zircon, and muscovite).

A slightly mafic facies, having composition of granodiorite; forms transitional zone $1 / 2-1$ mile wide between normal massive quartz monzonite and gneissoid quartz diorite in several places; this facies, mapped with quartz monzonite on pl. 1 along northwestern margin of gneiss and associated quartz diorite of hills north and northwest of Barstow (fig. 5), along northern margin of similar rocks in San Bernardino and San Gabriel Mountains north of the San Andreas fault zone, and in mountains south of this fault zone in vicinity of Sawmill and Liebre Mountains. 
Quartz monzonite Mesozoic in age. Lower age limit of quartz monzonite, that of youngest rock unit it intrudes, namely, hypabyssal and metavolcanic rocks of probable Mesozoic age, and granite and quartz monzonite unit of probable Late Jurassic or Cretaceous age in areas east of Mojave River. Upper age limit that of quartz latite dikes of Cretaceous or early Tertiary age that intrude it in Harper Valley area. Therefore quartz monzonite possibly Late Jurassic or more probably Early Cretaceous in age.

Age calculations based on lead-alpha ratios in zircon content of quartz monzonite made on three samples by T. W. Stern (written commun., March 13, 1957, to D. F. Hewett and W. C. Smith) as follows: sample from center sec. 25, T. 8 N., R. 16 W., S.B.B. and M., west Antelope Valley 6 miles west of Fairmont, $86 \pm$ 10 million years; sample from SW1/4 sec. 2 , T. 9 N., R. 12 W., S.B.B. and M., Rosamond Hills 3 miles northeast of Rosamond, $95 \pm 10$ million years; sample from NW1/4, sec. 31, T. 31 S., R. 43 E., M.D.B. and M., north Harper Valley 2 miles east of Fremont Peak, $85 \pm 10$ million years ( $90 \pm 10$ million years from monazite); sample from $\mathrm{SW} 1 / 4$ sec. 31 , T. 5 N., R. $3 \mathrm{~W}$., Granite Mountains, near Deadman Point $112 \pm 10$ million years (this may be from granite and quartz monzonite). These ages are all within the Cretaceous period.

\section{GRANITE}

Most extensive outcrops in the Tehachapi Mountains southeast of Garlock fault from San Andreas fault 21 miles northeastward, west of Mesquite Canyon in El Paso Mountains, in western Rand Mountains, in Bissell Hills west of Rogers Lake, in hills east and southeast of Rogers Lake to Mirage Valley, in hills north of Sidewinder Mountain and 2 miles northeast of Victorville, and in vicinity of Fremont Valley near Koehn Lake.

Mapped by Crowell (1952, pl. 1, p. 10) and Wiese (1950, pl. 1, p. 24-27) in Tehachapi Mountains.

Granite generally pinkish cream white, nongneissoid, medium grained; composed essentially of quartz, potassic feldspar (orthoclase, microcline, locally perthite), and plagioclase (oligoclase); potassic feldspar predominant over plagioclase in most places. Less than 1 percent accessory minerals (muscovite, biotite, apatite, sphene, zircon, and magnetite, in order of decreasing abundance).

Granite occurs as stocks with numerous offshooting apophyses and dikes of pegmatite and aplite intrusive into quartz monzonite, quartz diorite, and older rocks. Granite Mesozoic in age. Most granite presumably slightly younger than quantz monzonite of Late Jurassic or Cretaceous age.

\section{PEGMATITE AND APLITE}

Not shown on plate 1. Exposed in hills between Rogers Lake and Mirage Valley. Most widespread at Saddleback Butte and vicinity, 17-20 miles east of Lancaster (fig. 25; Dibblee, 1958c). Other occurrences at Lovejoy Buttes (Dibblee, 1959a), hills north of Kramer (figs. 46, 47, and Dibblee, 1958a), hills west of Harper Valley, hills north and northeast of Gravel Hills, in western Rand Mountains, and in El Paso Mountains west of Mesquite Canyon.

Rocks cream white with textures ranging from coarse pegmatite (grain size as large as $11 / 2$ inch) through graphic granite to aplite; dikes generally coarse in interior, finer along outer margins, commonly have textural zoning. Dikes composed essentially of quartz, potassic feldspar (orthoclase or microcline), and some plagioclase (albite-oligoclase); minor muscovite and biotite; some dikes near Harper Valley contain hornblende, rarely black tourmaline, but lack more exotic minerals.

Occur as dikes a few inches to a few feet wide, either scattered or in swarms, intrusive into quartz monzonite and adjacent older rocks. Probably represent final pulse of plutonic intrusion in western Mojave Desert. Possibly Jurassic but more likely Cretaceous in age.

Age calculation based on lead-uranium ratio in euxenite from a pegmatite dike in quartz monzonite and hornblende gabbro determined as 72 million years, or late Cretaceous (T. W. Stern, written commun., March 13, 1957, to D. F. Hewett and W. C. Smith).

\section{HYPABYSSAL ROCKS QUARTZ LATTTE}

Quartz latite forms dikes, mostly less than 10 feet wide but one as wide as 500 feet, in hills south of Boron (Dibblee, 1960d, p. 86-87), and in Fremont Peak area. Intrusive into quartz monzonite and older rocks, therefore not older than Cretaceous; quartz latite fragments present in Barstow Formation, therefore not younger than late Miocene. Quartz latite most likely either Cretaceous or early Tertiary in age.

Quartz latite white or pale bluish pink to gray, weathers tan; very hard, felsitic, massive to rarely faintly flow banded. Composed of microcrystalline potassic feldspar and sodic plagioclase partly altered to sericite, and traces of hematite. Commonly contains a few small phenocrysts of clear quartz, feldspar, and minute flakes of biotite.

\section{TERTIARY SEDIMENTARY AND VOLCANIC ROCKS GENERAL FEATURES}

Deposits of Tertiary age in the western Mojave Desert region consist of a great variety of nonmarine sedimentary, pyroclastic, and volcanic rocks, and some 


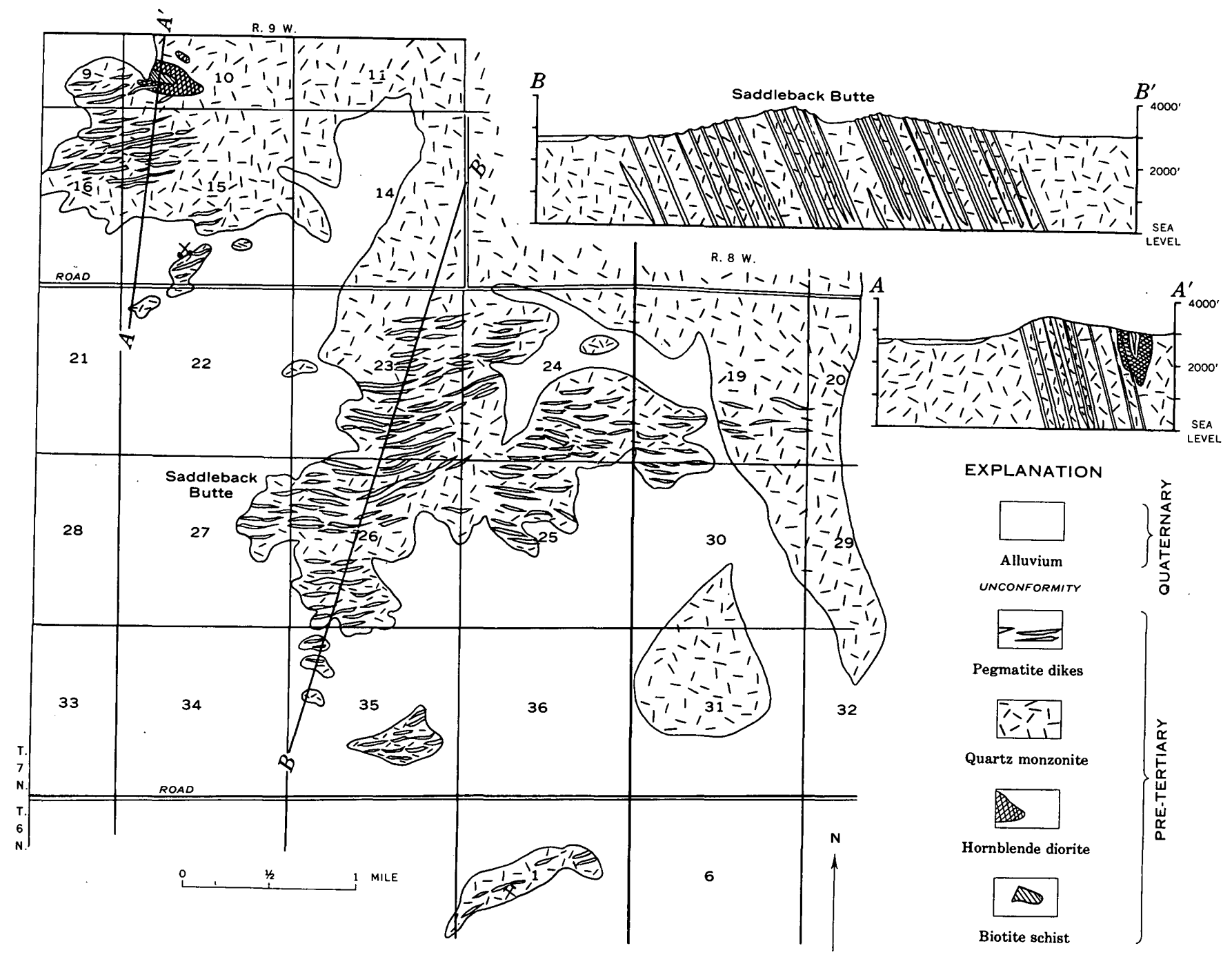

FTaUre 25.-Geologic map and sections of Saddleback Butte area east of Lancaster.

marine sedimentary rocks near the San Andreas fault zone (fig. 2).

Throughout the western Mojave Desert, the Tertiary formations rest unconformably upon a surface of preTertiary crystalline rocks that underwent deep erosion during Late Cretaceous and early Tertiary time. Therefore the age of the lowest Tertiary strata differs greatly from one area to another, depending on when the eroded bedrock surface first became a valley floor or became submerged under a sea transgressing from the southwest.

Because of lithologic variations and the lack of fossils in most of the stratigraphic units of Tertiary age, it is difficult if not impossible to correlate these units from one area to another. Such uncertainties make it impossible to describe all the various rock units in chronological order. The mapped area, therefore, has been divided into five parts, in each of which the stratigraphic units can be correlated and a definite sequence recognized: the southern, western, central, eastern, and northern parts of the western Mojave. Rock units exposed in these parts are described in ascending order in the following sections of this report. The exposed sequences and their probable lithologic correlations are illustrated on plate 4 .

\section{ROCK UNITS OF SOUTHERN AND WESTERN AREAS \\ PALMDALE, VALYERMO, AND CAJON PASS AREAS SAN FRANCISQUITO FORMATION}

A marine sedimentary sequence of clay shale, sandstone, and conglomerate of Paleocene and Eocene(?) age, unconformable on pre-Tertiary gneissic rocks exposed in San Francisquito Canyon area westward from 
Bouquet Reservoir; referred to Martinez Formation in areas to west by Kew (1924) and Clements (1937). Here named for San Francisquito Canyon; type section exposed down that canyon from contact with gneissic rocks a quarter of a mile north of juncture with Cherry Canyon to contact with red beds of overlying Vasquez Formation at junction with Bee Canyon (just beyond southwest border of pl. 1, in Bouquet Reservoir quadrangle), or about 4 miles west of Bouquet Reservoir (fig. 26).
San Francisquito Formation also exposed in Big Rock Creek area southwest of San Andreas fault south of Valyermo (pl. 1; figs. 29,30); and in Cajon Creek just northeast of that fault 1 mile south of Cajon junction (pl. 1, fig. 31). In these areas referred to Martinez Formation by Noble (1954a, b).

Formation composed of interbedded shale and sandstone, shale predominant in lower, sandstone in upper part. Conglomerate interbedded in minor amounts with sandstone.

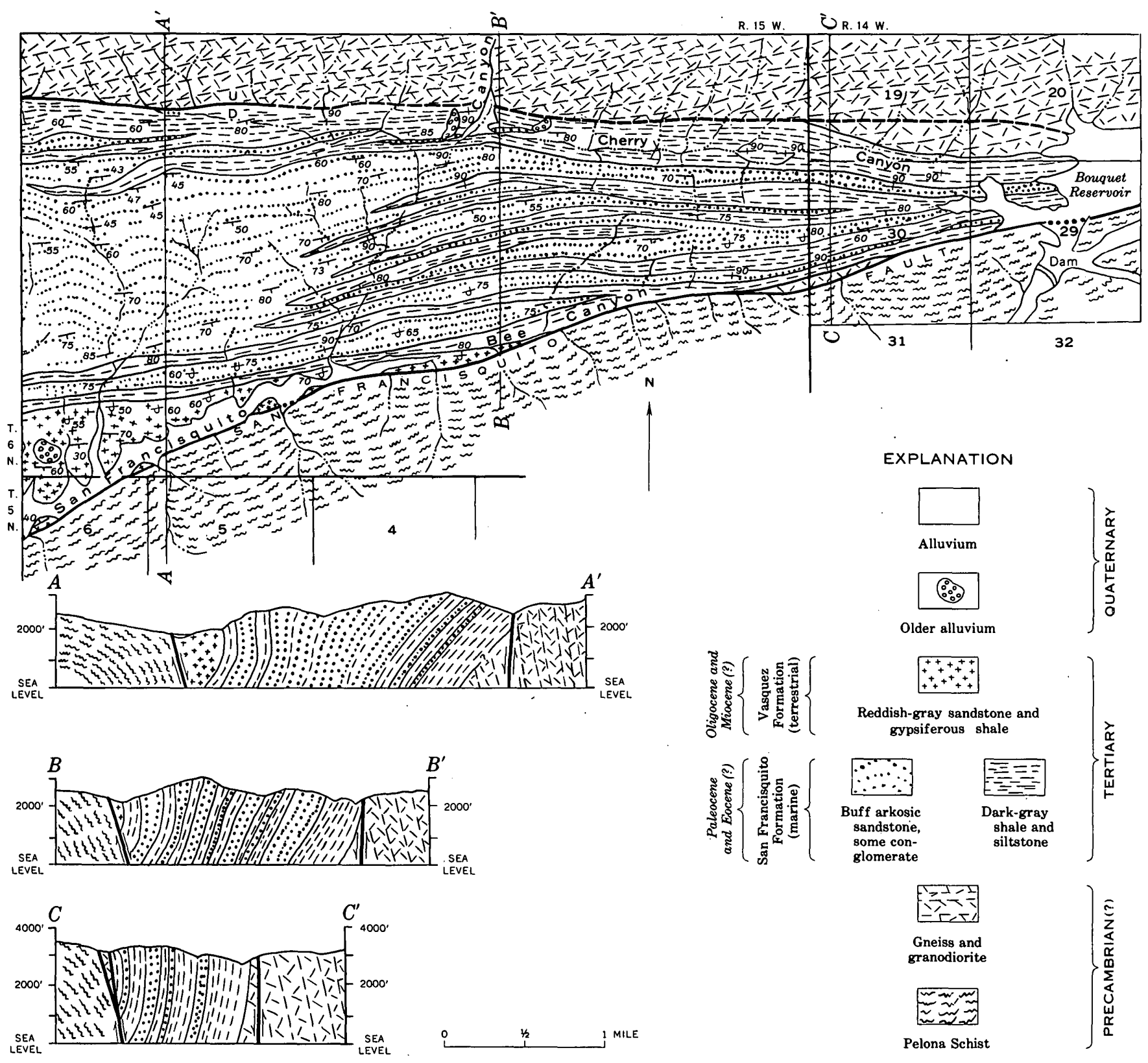

Fraure 26.-Geologic map and sections of San Francisquito Canyon area. 
AREAL GEOLOGY, WESTERN MOJAVE DESERT, CALIFORNIA

Clay shale dark gray; weathers brownish gray; well bedded, indurated, closely fractured, argillaceous to silty, highly micaceous. In places contains carbonized wood fragments. Commonly contains dark-gray flaggy hard calcareous layers few inches thick, and also darkgray calcareous concretions.

Sandstone forms hard massive strata from few inches to 20 feet thick; light olive gray; weathers buff to light brown, fine to medium grained, locally conglomeratic. Grains subangular, composed of quartz and feldspar (mostly plagioclase), biotite flakes common.

Conglomerate occurs as brown lenses and beds from a few inches to several tens of feet thick. Composed of well-rounded pebbles and cobbles in matrix of hard arkosic sandstone. Clasts composed of very hard rocks, mainly light-brown to gray felsitic and porphyritic igneous rocks, quartzite, granitoid rocks, pegmatite, aplite, and some gneiss. Local basal conglomerates composed of cobbles and boulders derived from underlying gneiss and quartz diorite.

Exposed sequences as follows in descending order:

San Francisquito Formation in San Francisquito Canyon (fig. 26)

Vasquez Formation:

Sandstone and siltstone, reddish-gray; basal contact conformable.

San Francisquito Formation:

Siltstone and sandstone, interbedded. . . . . . . 150

Sandstone; minor thin interbeds of shale.......... 650

Shale; minor interbedded sandstone............. 350

Sandstone, a few lenses of conglomerate......... 350

Shale; grades westward into sandstone............. 250

Sandstone; thickens eastward . . . .

Shale; grades westward into sandstone.......... 400

Sandstone. . . . .

Shale; grades westward into sandstone

Sandstone, a few lenses of conglomerate; thins eastward . . . . .

Shale; grades westward into sandstone...... . . . . . .

Sandstone; lenses out eastward . . . . . . . . . . . . .

Shale; grades westward into sandstone..............

Sandstone; several thin interbeds of conglomerate, siltstone, and shale, including a conglomerate lens about $20 \mathrm{ft}$ thick $400 \mathrm{ft}$ below top; thickens westward, thins eastward.

Shale; several thin beds of sandstone a few feet thick, except one $200 \mathrm{ft}$ from top that is as thick as $50 \mathrm{ft}$; sandstone beds mostly in upper half, which grades westward into sandstone........... 1, 300

Total exposed thickness, San Francisquito Formation . . 6, 900

Unconformity, partly in fault contact.

Gneissic rocks of pre-Tertiary age.
San Francisquito Formation in Big Rock Creek and Devils Punchbowl area (figs. 29, 30)

Punchbowl Formation.

Unconformity.

San Francisquito Formation: Estimated

Upper part: mainly sandstone and abundant inter- (feet)

beds of clay shale and lenses of conglomerate.... 2, 000

Lower part: mainly clay shale; a few thin beds of sandstone; includes several thick lenses of sandstone and conglomerate in most westerly exposures and thin basal lenses of sandstone and conglomerate on Pinyon Ridge.... 2, 000

Total exposed thickness, San Francisquito For-

mation . . .

Unconformity.

Gneissic rocks and quartz diorite of pre-Tertiary age.

In Cajon Creek about 1,500 feet of lowest part of formation present, composed of shale and sandstone, 10 feet of basal conglomerate, on gneissic rocks, unconformably overlain by Punchbowl Formation.

Marine molluscan fossils characteristic of Martinez Formation of Paleocene age of Mount Diablo region, 450 miles to northwest, reported from basal part of San Francisquito Formation by Dickerson (1914, p. 295), from lowest 400 feet of beds on Pinyon Ridge. Similar fossils found in basal part in vicinity of Elizabeth Lake Canyon beyond western border of figure 30 by students from University of California at Los Angeles. Unfossiliferous middle and upper parts of this thick sequence presumably range from Paleocene into Eocene age. Therefore, age of San Francisquito Formation considered to be Paleocene and Eocene(?).

\section{VABQUEZ FORMATION}

A sequence of terrestrial sedimentary and volcanic rocks of Oligocene and early Miocene(?) age, unconformable on pre-Tertiary crystalline rocks and unconformable below Punchbowl Formation in Soledad Pass area southwest of San Andreas fault (pl. 1; figs. 27, 28).

Exposed more extensively beyond southwest border of mapped area where it was described as Escondido Series by Hershey (1902b, p. 350-355), but because name preempted renamed Vasquez Series by Sharp (1935).

In Soledad Pass area, Vasquez Formation composed of volcanic rocks and minor amounts of sedimentary rocks. Volcanic rocks mainly andesite, a few questionable variations to dacite and mafic andesite, and some basalt and tuff-breccia. Andesitic rocks pink to 


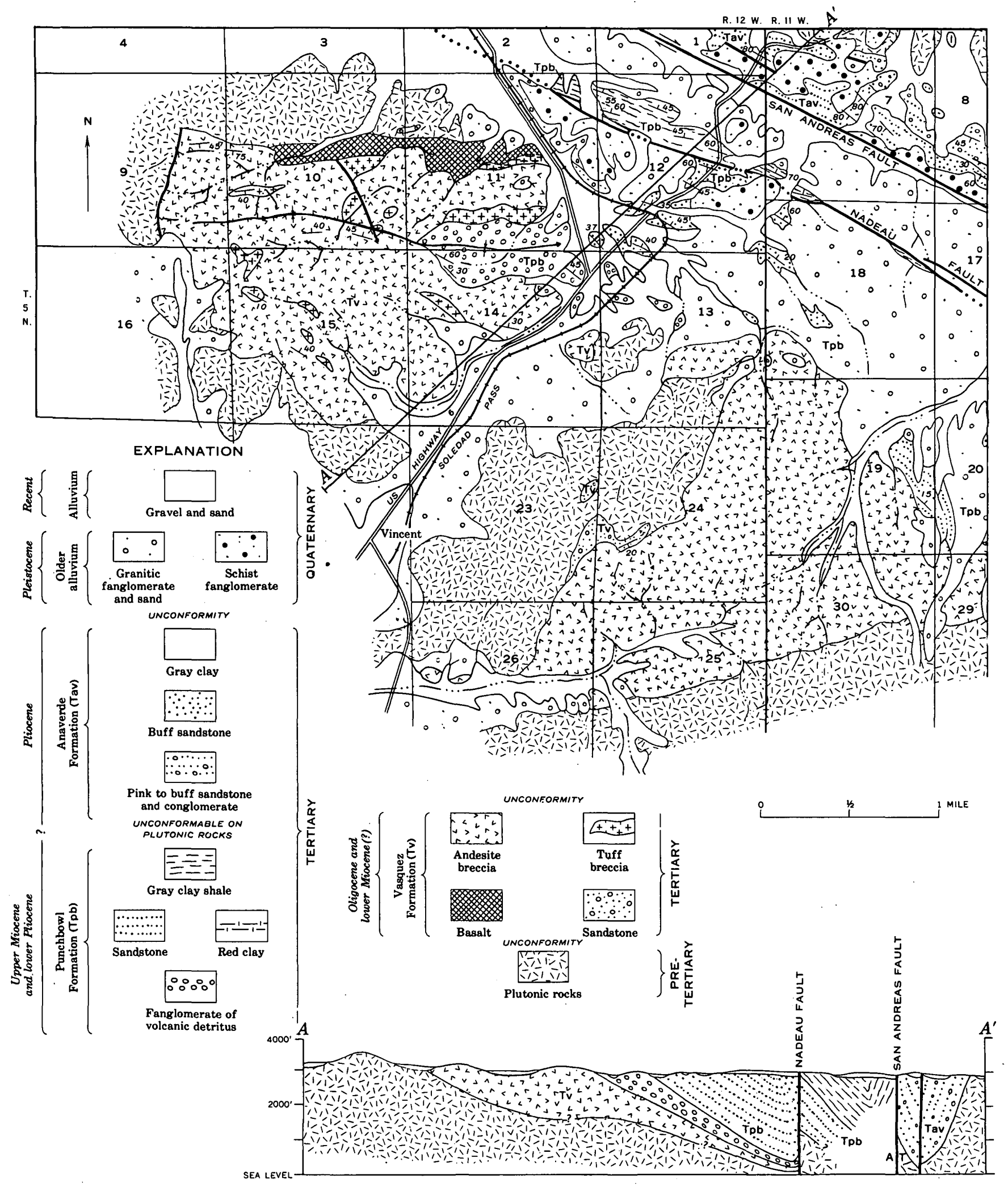

Frgure 27.-Geologic map and section of Cenozoic rocks of Soledad Pass area (in part modified after Wallace, 1949, and Noble, 1953). 


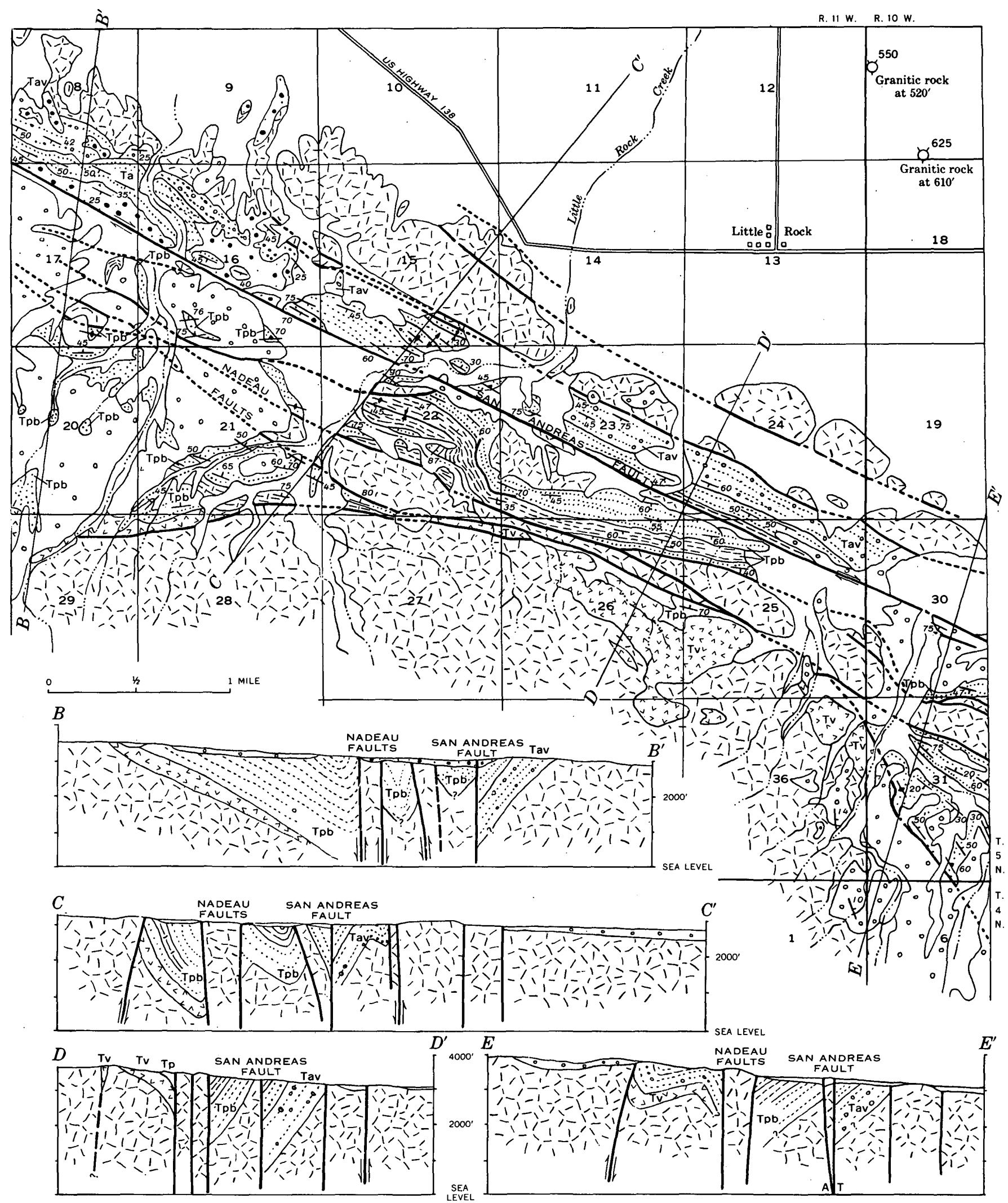

Fiaure 28.-Geologic map and sections of Cenozoic rocks of Little Rock area (in part modified after Noble, 1953). Explanation on figure 27. 
dark reddish brown, massive, felsitic to slightly porphyritic; contain scattered small phenocryts of plagioclase, and, in places, a few of quartz, biotite, and hornblende, in iron-oxide-bearing aphanitic groundmass. Basalt, black, fine grained; composed of plagioclase and augite(?) ; contains scattered small amygdules of calcite or chalcedony. Tuff-breccia, unbedded; composed of angular fragments as large as a foot across of andesitic rocks and silicified tuff in matrix of greenish- to cream-white silicified or opalized tuff.

Sedimentary rocks light gray, buff, red; composed of cobble-boulder conglomerate of granitic detritus, arkosic sandstone, and gritty siltstone. Deposited by streams.

Vasquez Formation unfossiliferous. In San Francisquito Canyon lies above Eocene(?) beds of San Francisquito Formation (fig. 26), therefore younger. In Soledad Pass unconformably underlies Punchbowl Formation; in Tick Canyon 12 miles west, unconformably underlies beds of early Miocene age (Jahns, 1940, p. 170). Vasquez Formation therefore most likely Oligocene, not younger than early Miocene in age.

\section{VAQUEROS FORMATION}

Two small erosional remnants of light-gray conglomerate and sandstone mapped as Vaqueros Formation by Noble (1954b, p. 39-40) on quartz diorite southwest of Cajon Junction north of San Andreas fault (fig. 31) contain marine molluscan fossils common in Vaqueros Formation of early Miocene and Oligocene(?) age in Coast and Transverse Ranges.

\section{PUNCHBOWL FORMATION}

A sequence of terrestrial sedimentary rocks of upper Miocene and lower Pliocene age exposed in northeastern margin of San Gabriel Mountains (pl. 1); unconformable on Vasquez Formation, San Francisquito Formation, and pre-Tertiary crystalline rocks (pl. 1). Mapped and named by Noble $(1953 ; 1954$ a) for section superbly exposed in Devils Punchbowl (figs. 29, 30), the type locality.

In Devils Punchbowl area southwest of San Andreas fault, Punchbowl Formation lies unconformably on San Francisquito Formation; southeastward, laps onto Pelona Schist; about 5,000 feet exposed, top eroded (figs. 29, 30). Formation mostly thick-bedded buff white to locally pink medium- to coarse-grained arkosic sandistone; grades downward into gray to red cobble-boulder conglomerate at base; upward into medium-grained white sandstone and interbedded red to green siltstone.

From Little Rock Creek to Soledad Pass (figs. 27, 28) about 2,200 feet of Punchbowl Formation exposed; mostly sandstone containing several lenses of red gypsiferous clay, and basal lens of fanglomerate derived from underlying andesite of Vasquez Formation.

In Cajon Canyon area northeast of San Andreas fault, sequence assigned to Punchbowl Formation (Noble, 1954a; 1954b, pl. 1) unconformable on San Francisquito Formation and quartz diorite; overlain conformably by Crowder Formation (figs. 31, 32) ; sequence about 5,500 feet thick and lithologically almost identical to Punchbowl Formation of Devils Punchbowl area.

In nearly all exposures of Punchbowl Formation on both sides of San Andreas fault, clasts mostly of granitic rocks, some of gneissic rocks, and few of Pelona Schist, San Francisquito sandstone, and Vasquez andesite.

Punchbowl Formation younger than Vasquez For. mation which it overlies unconformably. Scanty mammalian fossil remains from lake beds just west of Little Rock Creek and from basal beds in Devils Punchbowl south of Valyermo, suggest late Miocene (Barstovian) age (Noble, 1953, and oral commun., 1958). Other remains found in all but basal beds of Punchbowl Formation of Devils Punchbowl area suggest early Pliocene (Clarendonian) age, whereas all remains found nearly throughout Punchbowl Formation of Cajon Canyon area suggest late Miocene (Barstovian) age (R. H. Tedford, University of California, Riverside, oral commun., 1963).

On basis of similar lithology and stratigraphic position above Vasquez Formation, Punchbowl Formation probably correlative in large part with Mint Canyon Formation (Kew, 1924) to the west, which also contains late Miocene (Barstovian) and early Pliocene (Clarendonian) mammalian faunas but which is overlain by marine strata containing late Miocene (Mohnian) foraminiferal and molluscan marine faunas (Jahns, 1940, p. 171-172; Durham, Jahns, and Savage, 1954, p. 66).

On basis of foregoing evidence, Punchbowl Formation here considered to be late Miocene and early Pliocene in age by vertebrate time scale.

\section{CROWDER FORMATION}

A sequence of fluviatile detrital sediments of mainly Pliocene age resting on Punchbowl Formation and on pre-Tertiary crystalline rocks and conformably overlain by older alluvium in Cajon Canyon area (pl. 1; figs. 31, 33). Here named for Crowder Canyon, the type locality (S1/2 sec. 13 , secs. $24,25,26$, T. 3 N., R. 6 W., fig. 31 ).

Formation about 1,800 feet thick at Crowder and Cajon Canyons (fig. 32), thinning to northwest and 


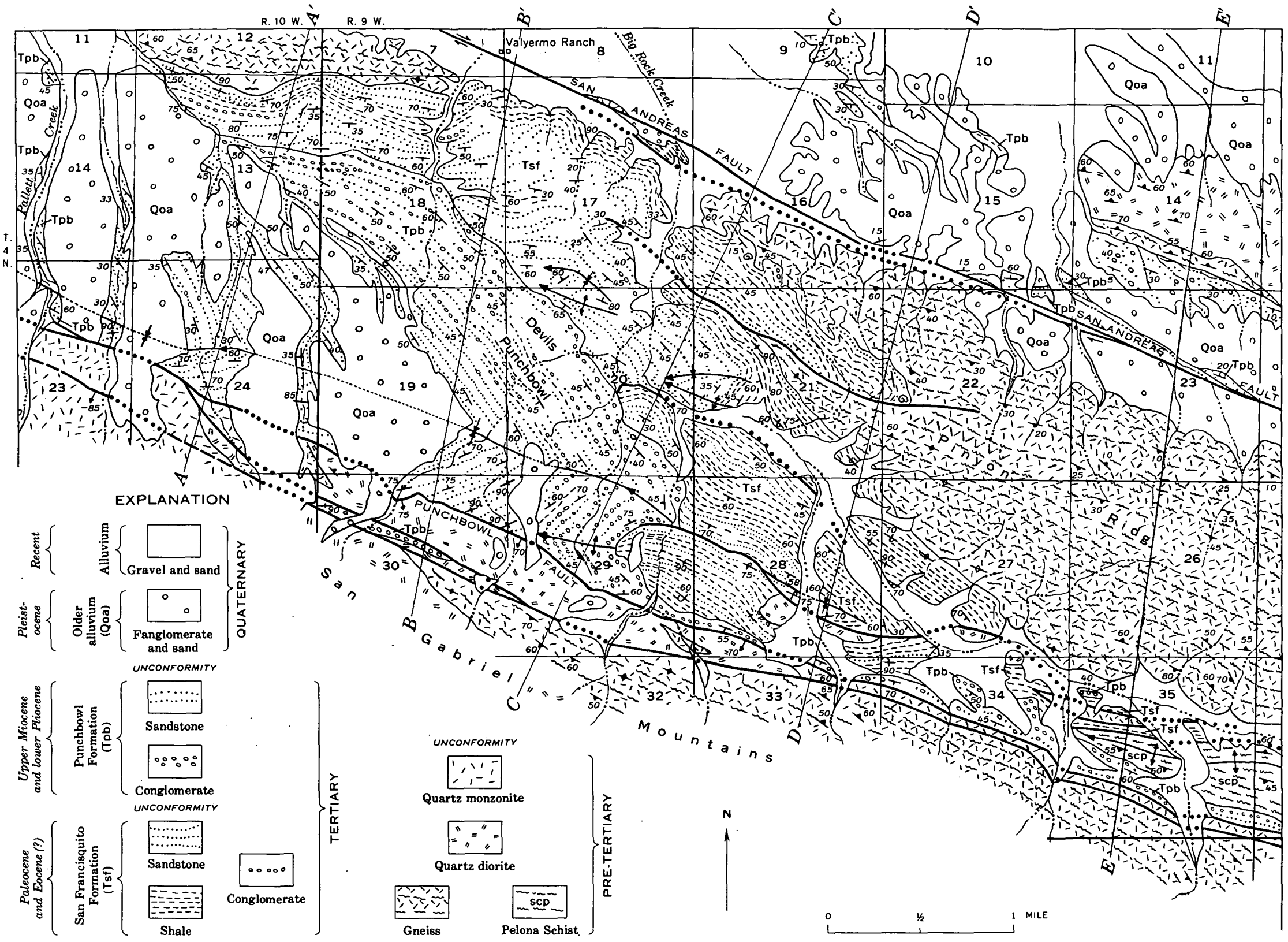



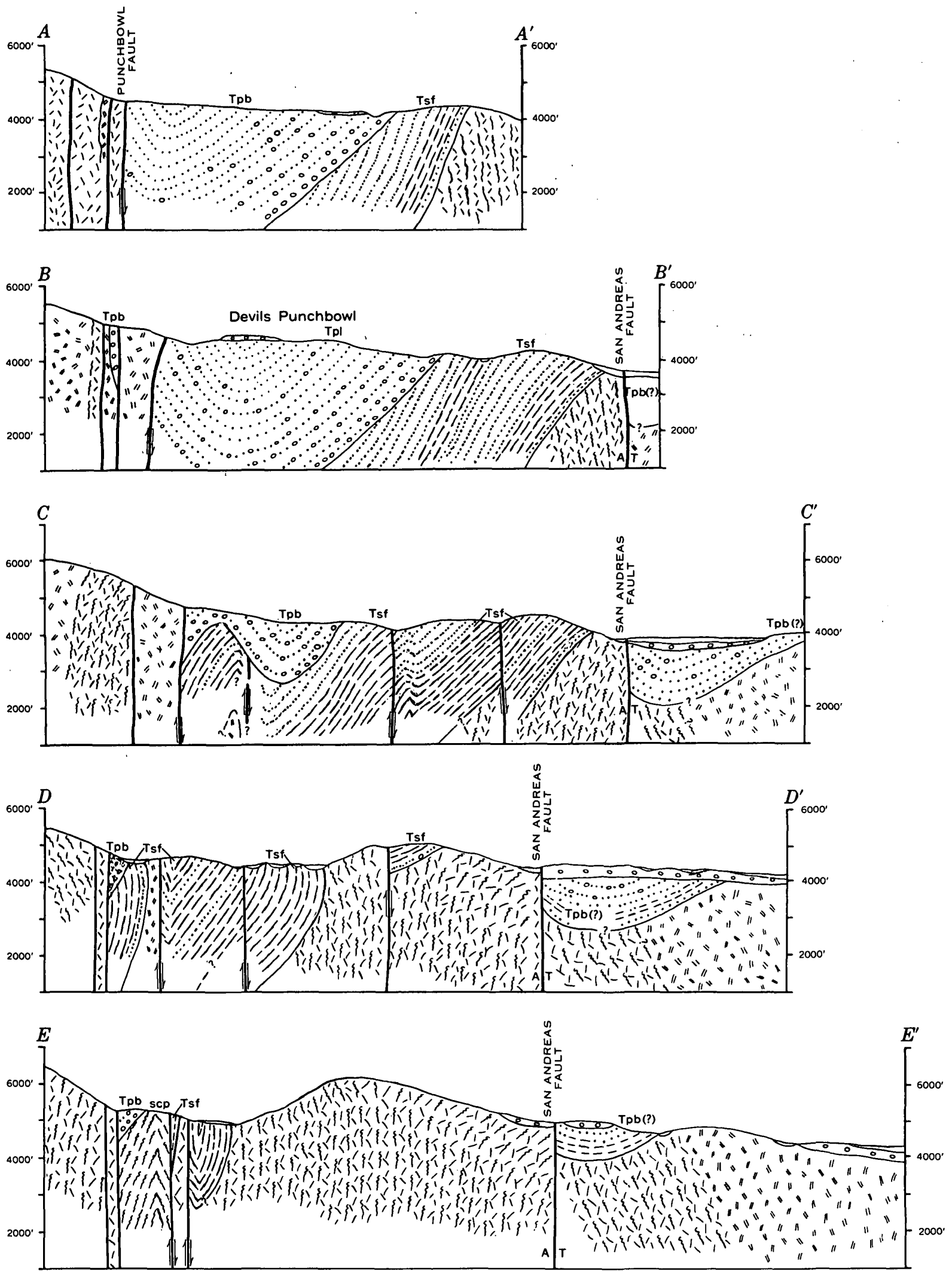

Fraure 30.-Sections of Devils Punchbowl area. Locations of sections are shown on figure 29. 


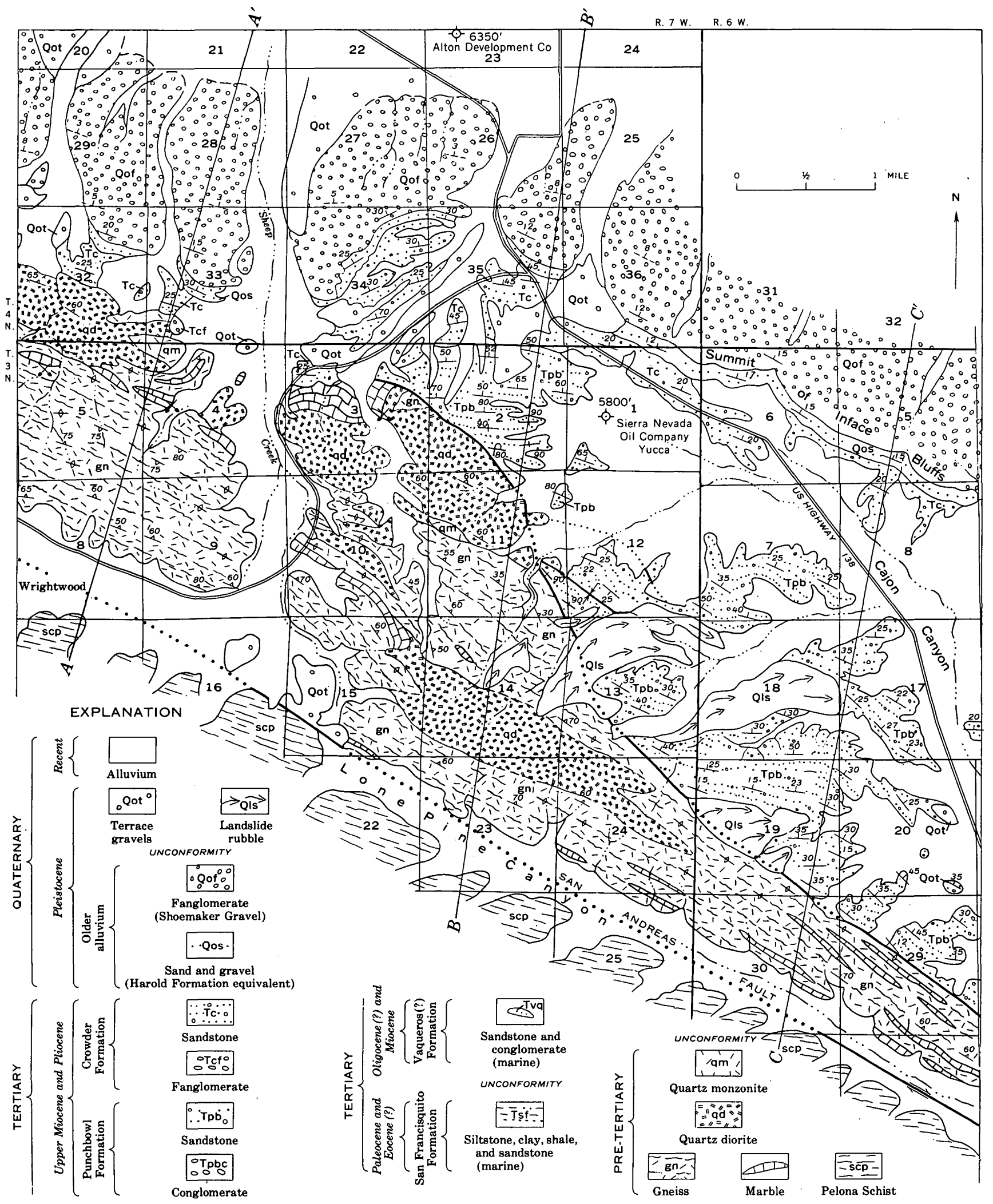

Figure 31.-Geologic map of Cajon Pass area, 


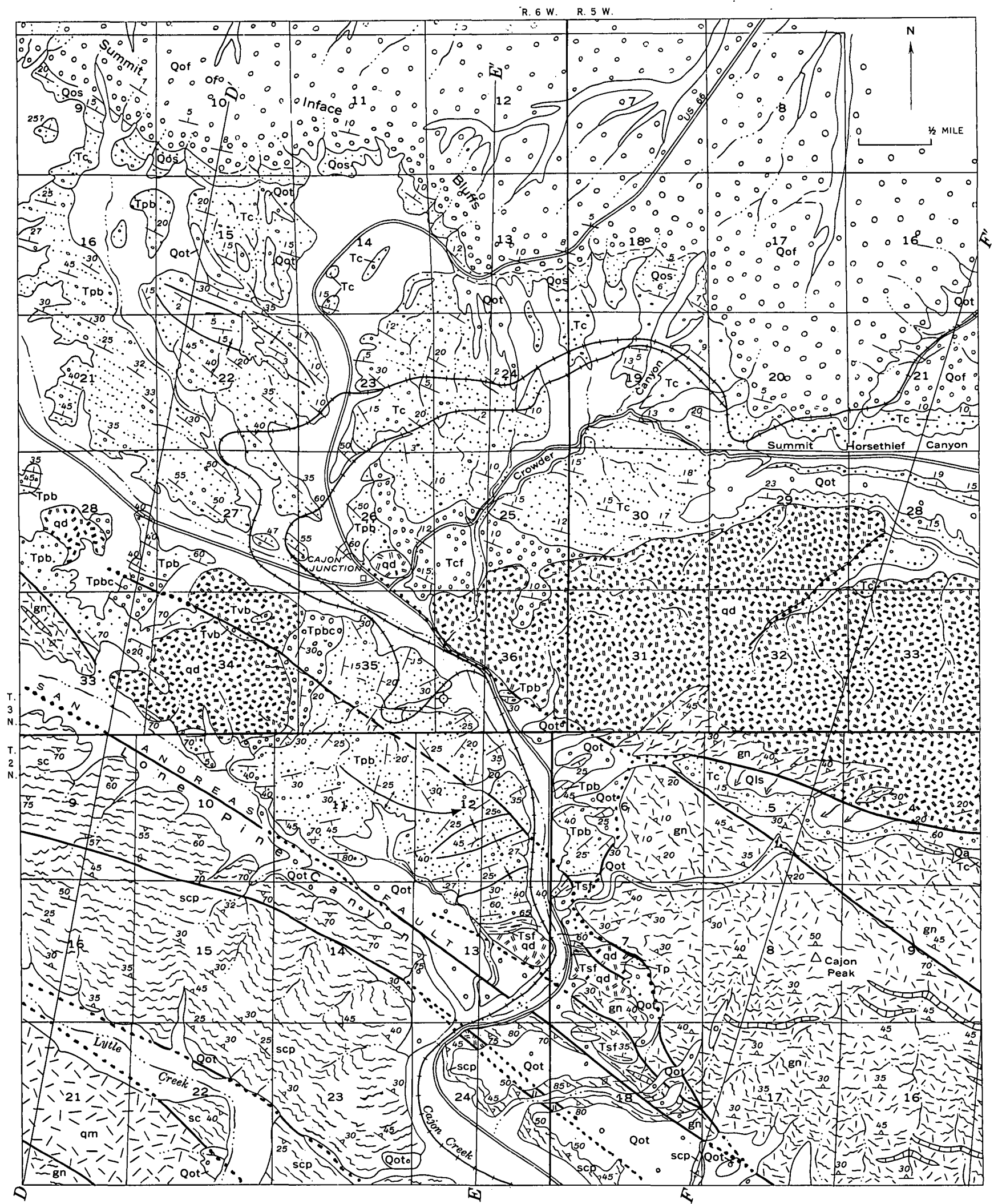

northwestern part (modified after Noble, 1954b). 

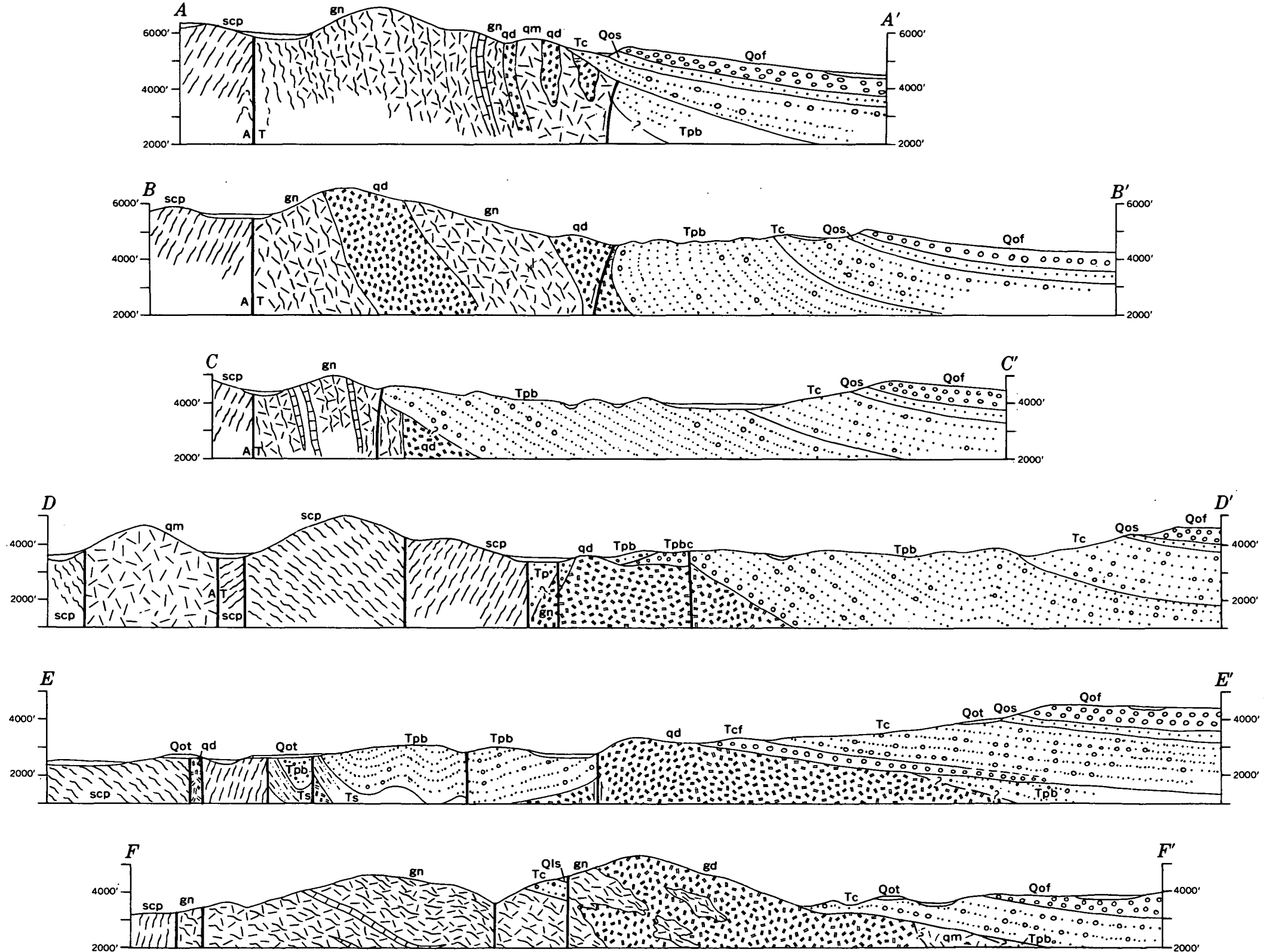

FIGURE 32.-Sections of Cajon Pass area. Iocations of sections are shown on figure 31 . 
southeast. Composed mostly of weakly consolidated sandstone and fanglomerate. Sandstone, gray white to buff white, friable, bedded, fine to coarse grained, conglomeratic, arkosic; contains scattered interbeds or lenses of pebble-cobble conglomerate and green to lightred siltstone. Pebbles and cobbles mainly of granitic rocks, some gneiss, felsite, porphyry, quartzite, schist, and quartz. Siltstone, gritty, sandy to argillaceous, in places containing small white calcareous nodules; westward from Cajon Canyon siltstone is light reddish gray; eastward greenish gray. Fanglomerate massive to obscurely bedded; composed of unsorted boulders and cobbles of mainly granitic detritus in matrix of coarse arkosic sand.

Crowder Formation younger than underlying Punchbowl Formation of late Miocene and early Pliocene age, and older than overlying basal greenish gray sandy beds of older alluvium that are probably cor-

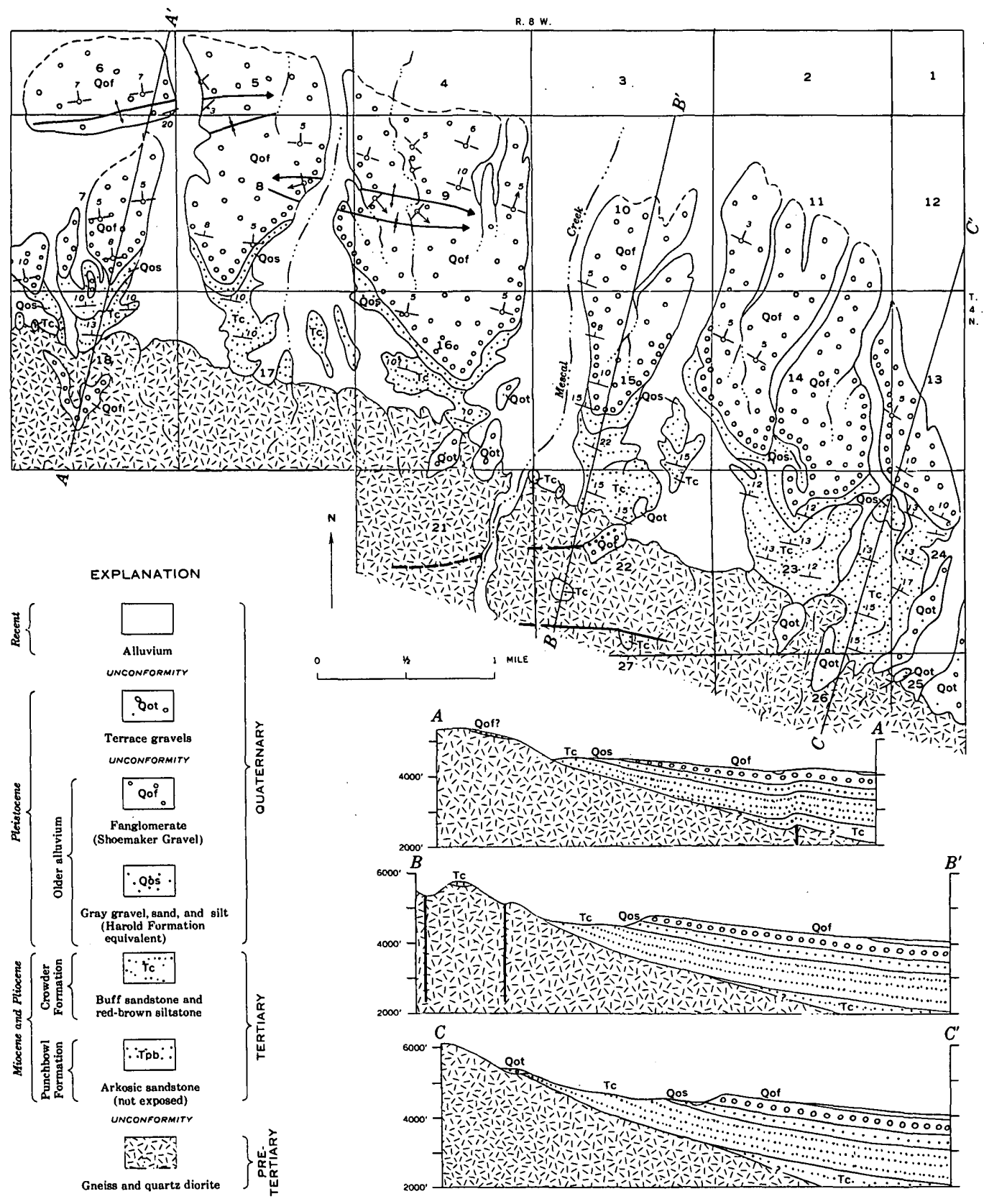

Frgure 33.-Geologic map and sections of Cenozoic rocks of San Gabriel Mountain foothill area near Mescal Creek (modified after Noble, 1954b). 
relative with Harold Formation of Noble (Pleistocene) of Palmdale area; therefore part if not all of Crowder Formation most probably of Pliocene age.

ANAVERDE FORMATION

Sequence of terrestrial sedimentary rocks of Pliocene age exposed along San Andreas fault zone for about 28 miles northwestward from Little Rock area. Named and mapped by Wallace $(1949$, p. 790, pl. 1) after Anaverde Valley. Type section hereby designated as sequence exposed 2-3 miles west-southwest of Palmdale (SW1/4 sec. 28, sec. $29 \mathrm{~N} 1 / 2$ sec. 33, T. 6 N., R. 12 W., fig. 34). Included in Escondido Formation (of former usage) by Simpson (1934, pl. 5).

Formation consists of four main rock types: dioritic breccia, pink arkosic sandstone and conglomerate, buff arkosic sandstone, and clay shale.

Dioritic breccia ("old arkose" of Wallace, 1949, p. 784 , pl. 1) a severely shattered mass of dark-gray medium- to coarse-grained diorite composed of plagioclase, hornblende, and biotite; rock incoherent and deeply weathered; most northwesterly exposures composed of weathered fragmented diorite in crumbly red arkosic sandstone.

Pink arkosic sandstone and conglomerate interbedded and intertongued; pink gray to buff friable, massive to poorly bedded; sandstone fine to coarse grained; pebbles and cobbles of conglomerate rounded, composed of granitic rocks, aplite, and pegmatite, in arkosic sandstone matrix.

Buff arkosic sandstone grading to nearly white; friable to moderately hard, massive to bedded, fine to coarse grained, locally pebbly; in places contains interbeds of micaceous siltstone.

Clay shale gray, soft, crumbly, thin bedded; contains veinlets and minute crystals of gypsum; in exposures 11/2 miles southwest of Palmdale contains numerous strata from less than 1 inch to several inches thick of white gypsum.

Formation severely deformed (figs. $27,28,34$ ) ; overlies, and in fault contact with, pre-Tertiary rocks; top eroded; exposed thickness about 1,500 feet in San Andreas fault zone; possibly thicker in area $11 / 2$ miles southwest of Palmdale (fig. 34). Pink arkosic sandstone and conglomerate forms lower unit; grades upward into buff arkosic sandstone, which in turn grades through interbedded sandstone and shale into overlying clay shale (figs. 28,34 ). Diorite breccia occurs as several discontinuous fault slivers southwest of Portal Ridge (Dibblee, 1961b).

Nineteen species of fossil plants reported by Axelrod (in Wallace, 1949, p. 791) from basal part of clay shale unit 31/2 miles west of Palmdale (R. E. Wallace, 1959, oral commun.; fig. 34) are only fossils found.
Flora assigned to Hemphillian Stage of lower middle Pliocene (Savage and others, 1954, p. 53).

Anaverde Formation lithologically similar to and possibly correlative with Peace Valley Beds of Crowell (1952). Supposedly younger than Punchbowl Formation to southeast, but lithologically similar and possibly in part correlative (Noble, 1953).

\section{PEACE VALLEY AREA \\ PEACE VALLEY BEDS OF CROWELL (1950)}

A lacustrine and fluviatile sedimentary sequence of Pliocene age unconformable on pre-Tertiary rocks and conformably overlain by Hungry Valley Formation in large area southwest of Liebre Mountain and east of Peace Valley (pl. 1). Described and mapped as Peace Valley Beds by Crowell (1950, p. 1631-1632, fig. 4; 1952, p. 13-14, pl. 1) and Jennings (1953, p. 9-13, pl. 1).

Formation consists of clay shale, siltstone, sandstone, and conglomerate. Clay shale and siltstone, gray, bedded, micaceous. Sandstone buff, well bedded, friable to hard, fine to medium grained, arkosic. Conglomerate buff to brown; composed mainly of rounded pebbles and cobbles of granitic rocks, aplite, and pegmatite, plus few of gneiss, quartz, porphyry, and sandstone.

About 4,000 feet of beds exposed within mapped area, thinning and coarsening eastward; forms upper part of 18,000 -foot sequence of Pliocene terrestrial beds exposed to south.

Fossils found in Peace Valley Beds are fresh-water mollusk and smooth-shelled ostracods of no diagnostic age significance (Crowell, 1950, p. 1638), and stickleback fish considered to be of Pliocene age (David, 1945, p. 315-318). Flora of fossil plants found in lower Peace Valley Beds in Piru gorge few miles south of mapped area considered to be of middle Pliocene (Hemphillian) age (Axelrod, 1950, p. 159-214).

\section{HUNGRY VALLEY FORMATION OF CROWELI (1950)}

A fluviatile sedimentary sequence of late Pliocene age overlying Peace Valley beds in hills between Peace Valley and Frazier Mountain and southwest of San Andreas fault. Named, described, and mapped in detail by Crowell (1950, p. 1633-1637, fig. 4; 1952, p. 14-16, pl. 1).

Weakly consolidated gray-white arkosic sandstone and pebble-cobble conglomerate; some interbedded light-red to greenish-gray sandy siltstone. Clasts of conglomerate mainly of granitic rocks, some of metamorphic rocks, others of Tertiary andesitic and felsitic volcanic rocks.

Formation about 4,000 feet thick; top eroded.

Vertebrate fossils found 600 feet above base of Hungry Valley Formation include teeth of large horse 


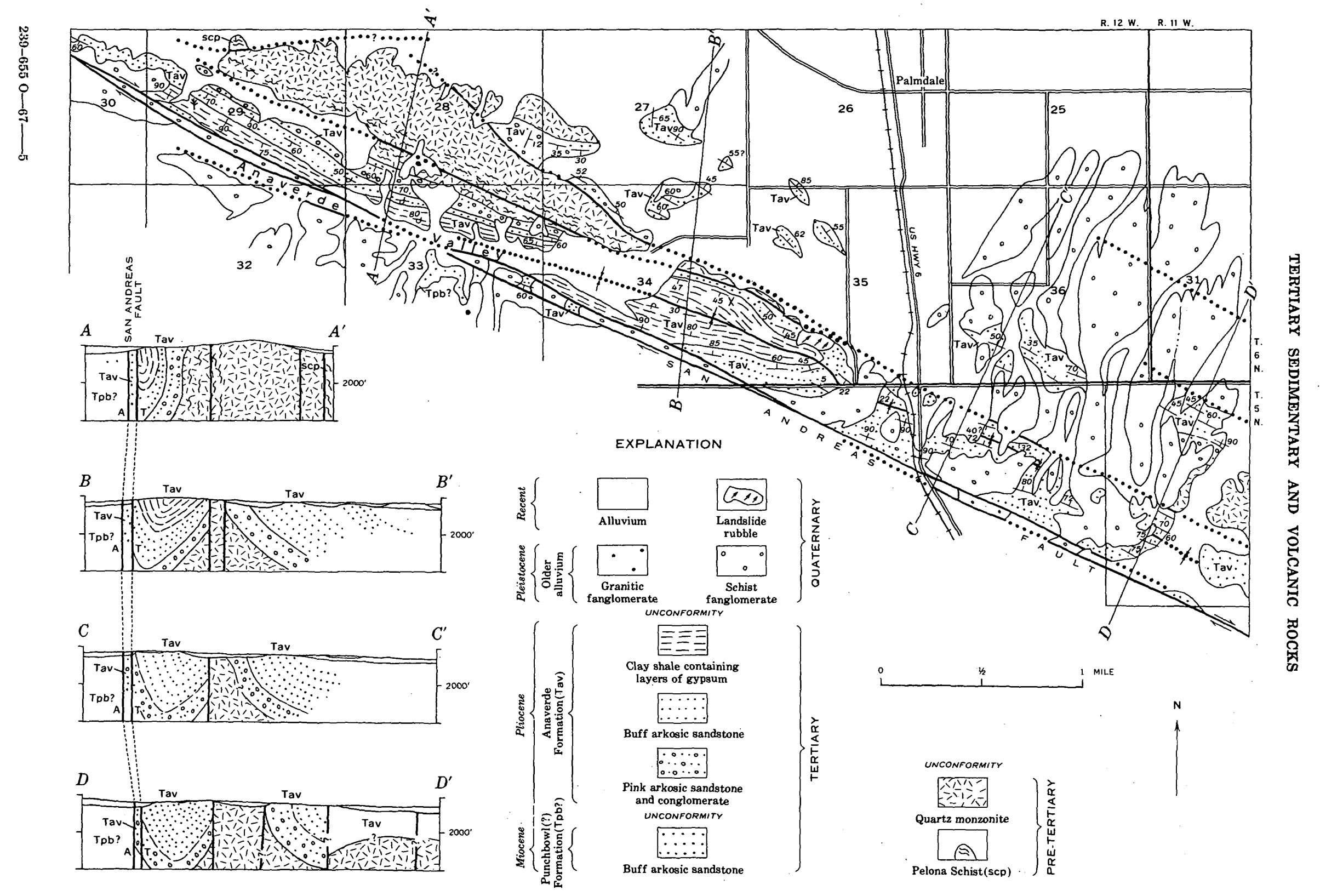

Fraure 34.-Geologic map and sections of Palmdale area (modified after Wallace, 1949, and Noble, 1953). 
Pliohippus or Plesippus; considered either late middle Pliocene (late Hemphillian) or early upper Pliocene (late Blancan) age by Chester Stock (in Crowell, 1950, p. 1638) ; overlying beds of formation considered to be upper Pliocene.

WEST ANTELOPE VAITEY ARBA

NEENACH VOLCANIC FORMATION

A volcanic sequence of Oligocene(?) and Miocene age unconformable on pre-Tertiary granitoid rocks and overlain by sedimentary rocks of late Miocene age.

In hills west of Antelope Valley, northeast of San Andreas fault, exposed as a narrow strip adjacent to this fault near Gorman, and from La Liebre ranch southeast to Pine Canyon (figs. 35-37). Formation hereby named for a former school in Neenach quadrangle. Type section exposed in large canyon about a mile east of La Liebre ranch (projected S1/2 sec. 14, sec. 23, T. 8 N., R. 17 W., San Bernardino meridian) in which all facies are present (fig. 36).

Andesite and felsite two major recognizable facies; minor exposures of perlite, tuff breccia, and bentonite; rare thin lenses of conglomerate, sandstone, and limestone reported by Wiese $(1950, \mathrm{p} .31)$.

Andesite flows dark reddish to purplish brown, aphanitic to slightly porphyritic, massive; some flows slightly vesicular, rarely scoriaceous. Thin sections show rock to be mass of plagioclase (calcic andesine) laths intermixed with iron oxides; most of phenocrysts are biatite largely replaced by hematite, chlorite, and epidote (Crowell, 1952, p. 11).

Felsite light colored, greenish gray, pink, red, brown to tan, flow banded to massive, aphanitic, very hard, siliceous; presumably in range of composition from rhyolite to dacite.

Perlite greenish gray to steel gray, massive to flow banded, vitreous, brittle; innumerable curved fractures; perlite-to-felsite transition rock contains spherulites; cavities and fissures filled with opal or chalcedony.

Tuff breccia cream white, massive, indurated, composed of angular fragments of felsite in fine-grained partly silicified tuffaceous matrix.

Andesite and felsite in part contemporaneous, andesite in part younger; perlite locally forms basal chilled facies of felsite; tuff breccia forms base of formation in type section and in Pine Canyon; small lens of felsite agglomerate at top.

Neenach Volcanic Formation pre-late Miocene in age. Considered possibly Oligocene, and early or middle Miocene, as suggested by its similarity to, and possible correlation with, andesitic and felsitic rocks of Vasquez Formation (Sharp, 1935) south of Sierra
Pelona, Kinnick Formation (middle Miocene) in Tehachapi area, and Tecuya Beds (Oligocene or Miocene) of Stock $(1920 ; 1932)$ and Vaqueros Formation as used by Hoots (1930) in southeastern San Joaquin Valley, all known to be of that age range.

\section{QUAIL LAKE FORMATION}

A marine and brackish-water sedimentary sequence of shale, sandstone, and conglomerate of late Miocene age exposed at west end of Antelope Valley; referred to Santa Margarita Formation by Wiese (1950, pl. 1, p. 32-53) and Crowell (1952, pl. 1, p. 12-13). Unconformable on Neenach Volcanic Formation and Mesozoic granite; gradational upward and laterally northeastward into fluviatile beds of Oso Canyon Formation. Exposed northeast of San Andreas fault, in hills northwest of Quail Lake, also in hills to southeast near La Liebre Ranch (pl. 1).

Formation herein named for Quail Lake; type section exposed from point $21 / 2$ miles N. $60 \mathrm{~W}$. of center of Quail Lake eastward down ridge for $11 / 2$ miles (fig. $35)$.

Lower part of formation mostly shale that grades laterally northeastward into sandstone; conglomerate at base; upper part nearly all sandstone.

Shale dark brown to nearly black; bleaches light brown on weathering; thin bedded, micaceous; ranges from ellipsoidal-fracturing clay shale to harder platyfracturing semisiliceous shale; southeast of Quail Lake, shale light colored, porcelaneous, probably tuffaceous.

Sandstone gray white; weathers buff; moderately hard, massive to bedded, medium to coarse grained, commonly conglomeratic, arkosic. Conglomerate composed of rounded cobbles and pebbles of granitic rocks and pink to white (bleached) rhyolite in matrix of coarse arkosic sandstone.

Sequence of type section as follows in descending order:

Quail Lake Formation exposed at type locality $2 \frac{1}{2}-1 \frac{1}{2}$ miles westnorthwest of Quail Lake

Sandstone; contains shell fragments in a few places. Grades eastward, northward, and upward into terres- Estitrial red and green sandstone, siltstone, and fanglom- $\begin{gathered}\text { mated } \\ \text { thickness }\end{gathered}$ erate of Oso Canyon Formation; downward through (feet) interbeds into shale ........ 1, 000

Shale; contains several thin beds as much as 5 feet thick of sandstone, which increase in abundance as shale grades northward into sandstone.............. 1, 300

Sandstone and conglomerate; contain scattered pebbles and cobbles that increase in abundance and size as sandstone grades downward into basal boulder conglomerate of granitic detritus; clasts of purple-brown andesite where this formation rests unconformably on Neenach andesite..... 250

Total thickness, Quail Lake Formation ........ 2,550 


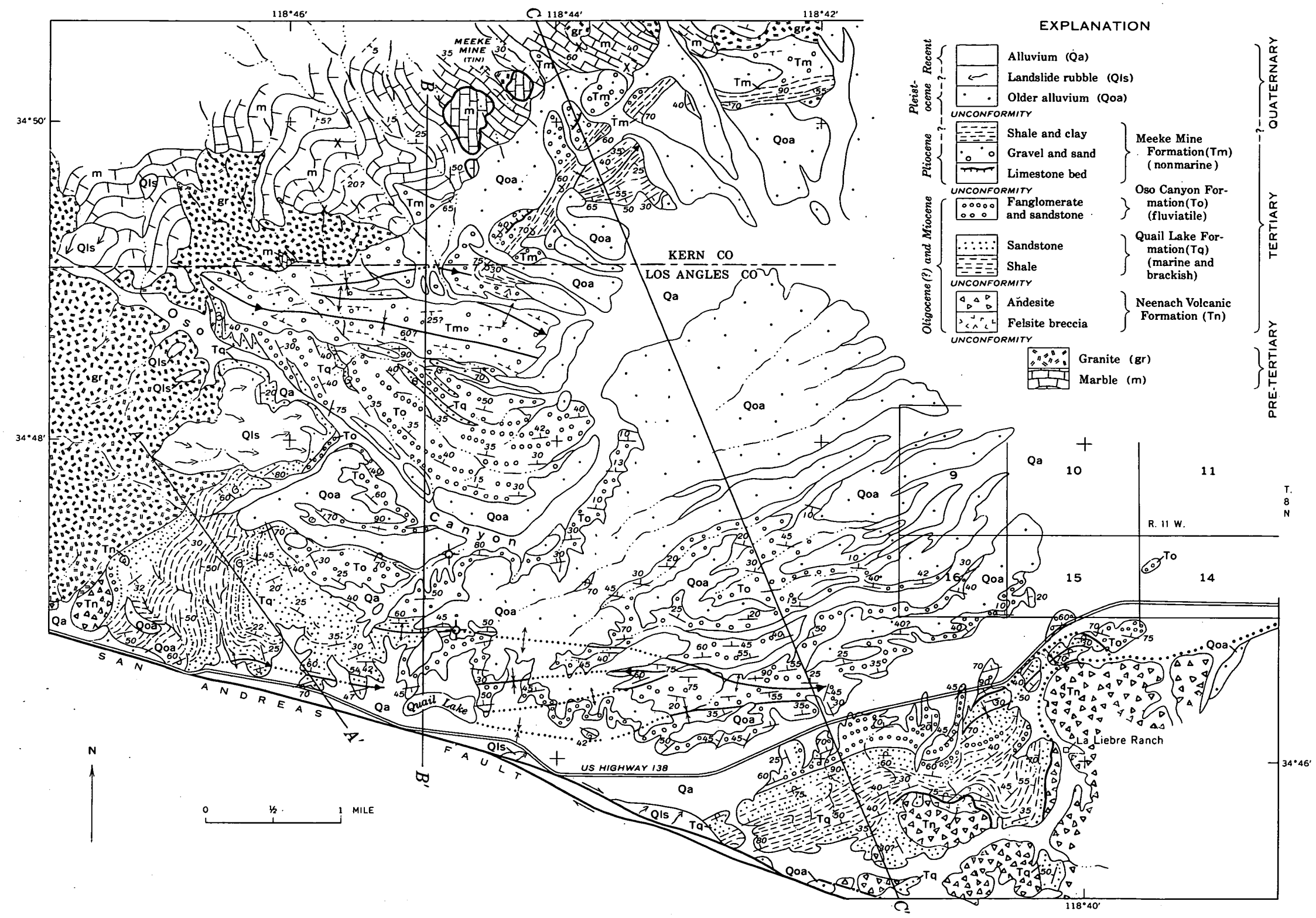

Fraure 35.-Geologic map of lower Oso Canyon and La Liebre Ranch area, west end of Antelope Valley (modified after Wiese, 1950, and Crowell, 1952). 


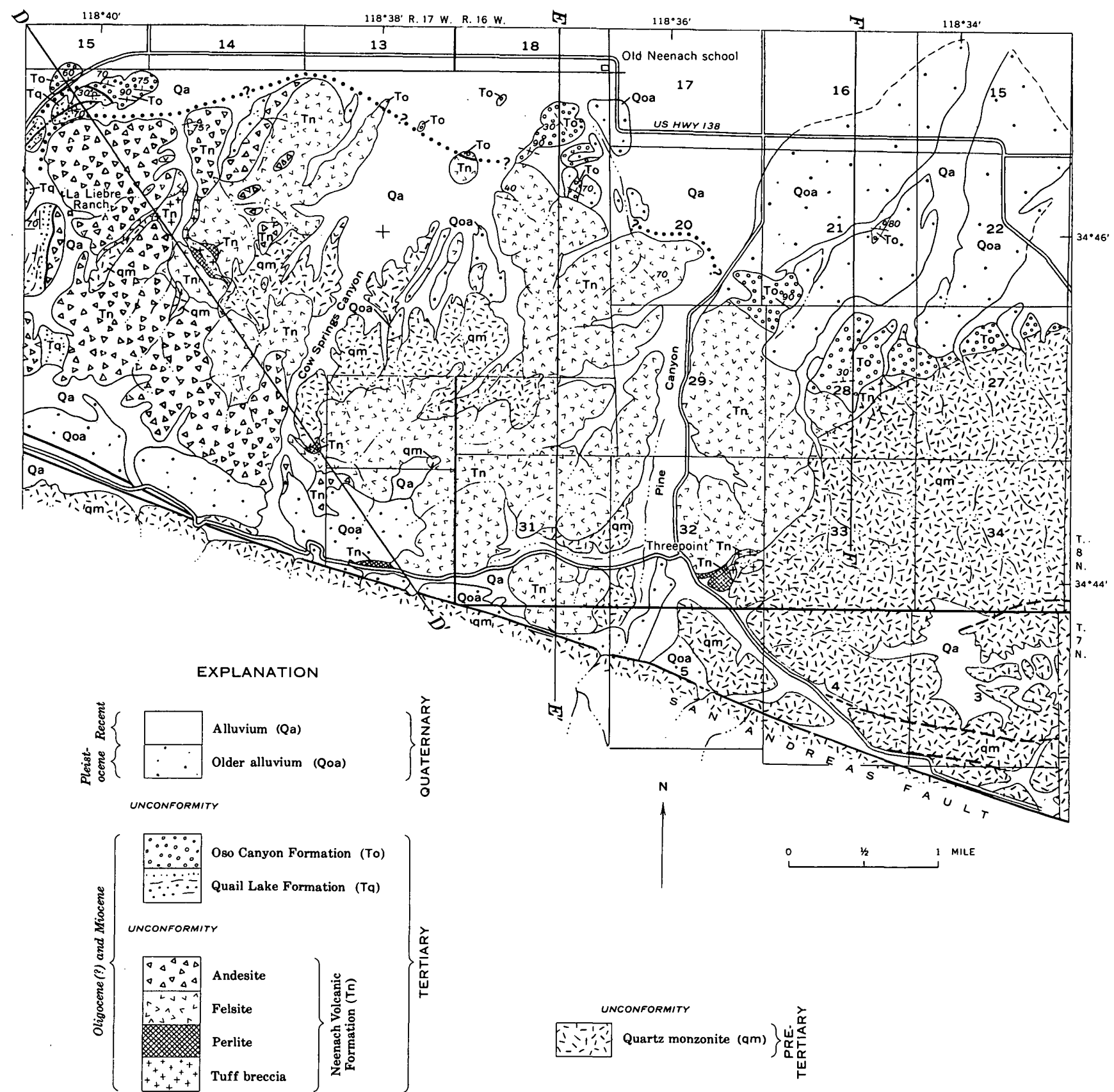

Figure 36.-Geologic map of Cow Springs Canyon and Pine Canyon area, west end of Antelope Valley (in part modified after Wiese, 1950.)

In area west of La Liebre ranch, formation attains maximum thickness of 2,700 feet. Section exposed here strikingly similar to that of type section northwest of Quail Lake (figs. 36, 37) but lacks marine fossils.

Marine molluscan and echinoid fossils from beds mapped as Quail Lake Formation in Oso Canyon and vicinity include four species present in Santa Marga- rita Formation (upper Miocene) of southern San Joaquin Valley as mapped by Hoots $(1930, \mathrm{pl} .1)$; on this basis, Quail Lake beds correlated with and referred to that formation by Wiese $(1950, \mathrm{p} .33, \mathrm{pl} .1)$ and Crowell (1952, p. 12-13, pl. 1).

\section{OSO CANYON FORMATION}

A coarse fluviatile sedimentary sequence of late Miocene age exposed at west end of Antelope Valley; 

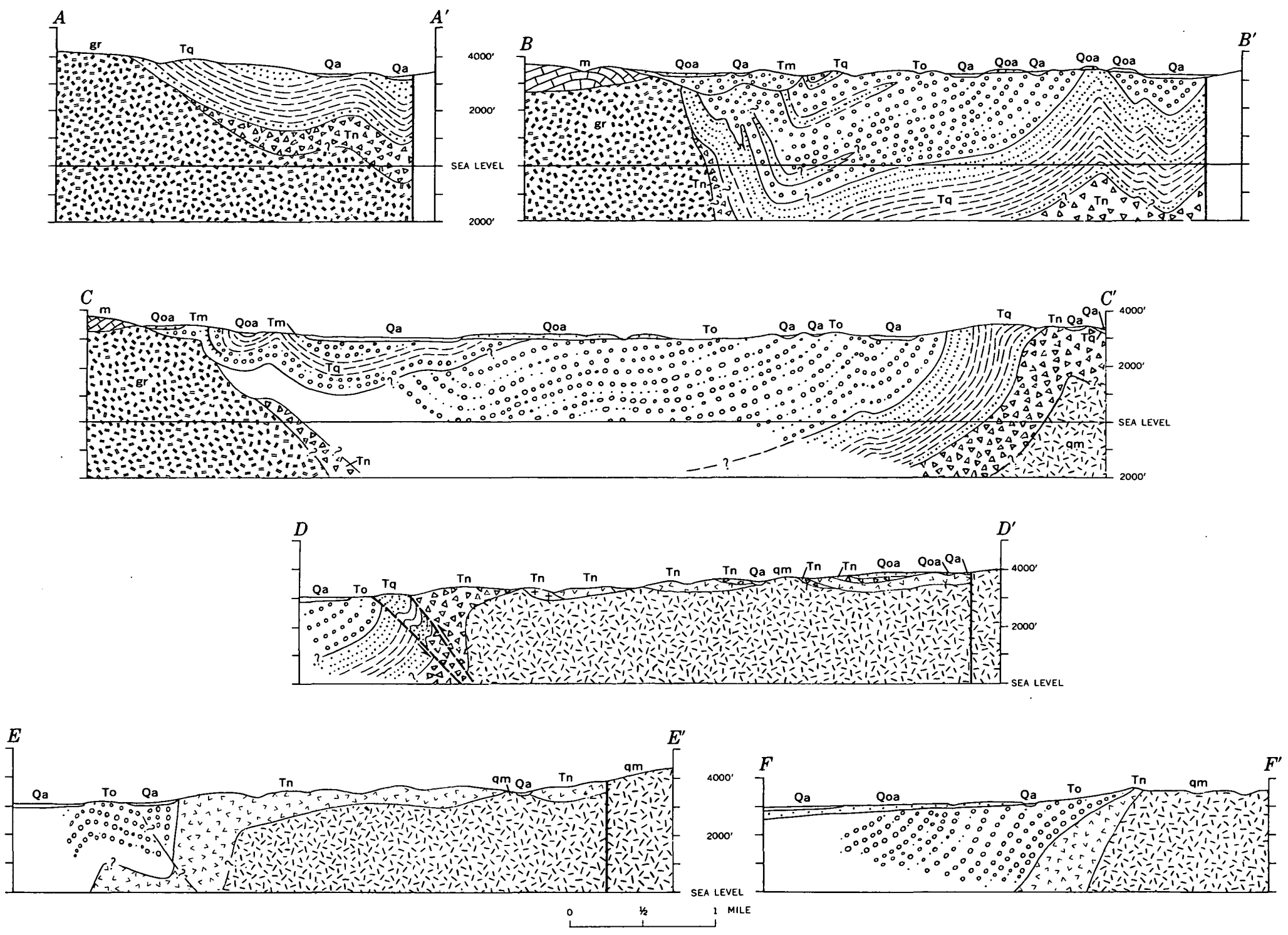

Frgure 37.-Sections of hills at west end of Antelope Valley. Locations of section are shown on figures 35 and 36. 
mapped by Wiese (1950, pl. 1) as continental deposits, Miocene(?), and Santa Margarita Formation. Lower part gradational southwestward and downward into Quail Lake Formation; northeastward becomes unconformable on Neenach Volcanic Formation and on Mesozoic granite; unconformably overlain by Meeke Mine Formation.

Formation herein named for Oso Canyon; type section exposed from contact with buff sandstone of Quail Lake Formation two-thirds of a mile north of west end of Quail Lake along line N. $20^{\circ}$ E. for 2 miles, across Oso Canyon to contact with overlying Meeke Mine Formation (fig. 35).

Formation about 5,500 feet in maximum thickness; composed of interbeds and intergradations of fanglomerate, conglomerate, sandstone, and siltstone. Fanglomerate composed of unsorted subrounded clasts ranging from pebbles to boulders in matrix of graywhite friable coarse arkosic sandstone. Conglomerate similar but clasts are moderately sorted pebbles and cobbles. Sandstone buff white to red, friable, fine to coarse grained, commonly gritty or conglomeratic, arkosic. Siltstone greenish gray to red, soft, micaceous, argillaceous to sandy, commonly pebbly. Fanglomerate massive, other sediments bedded, commonly crossbedded and with filled stream channels. Formation composed mainly of detritus of granitic rocks, including pegmatite, aplite, and abundant fragments of bleached white massive to flow-banded rhyolite identical to that of Neenach Volcanic Formation.

Oso Canyon Formation same age as Quail Lake Formation (late Miocene) into which it grades laterally.

\section{MEEKE MINE FORMATION}

Sequence of fluviatile gravel and lacustrine clay of probable late Pliocene or early Pleistocene age exposed discontinuously in southeastern foothills of Tehachapi Mountains from Oso Canyon northeastward 8 miles to Antelope Canyon (pl. 1; fig. 35). Mapped as Pliocene(?) lake deposits by Wiese $(1950$, p. $35-36$, pl. 1). Unconformable on Oso Canyon Formation and preTertiary rocks; about 1,500 feet thick; unconformably overlain by older alluvium.

Formation named for nearby Meeke tin mine. Type section that exposed from contact with Oso Canyon Formation $21 / 2$ miles north of west end of Quail Lake northeast 1 mile to Kern-Los Angeles County boundary (fig. 35).
Formation consists of two units of gravel separated by one of clay and clay shale. Sequence as follows:

Meeke Mine Formation exposed from 1 to 4 miles northeast of Oso Canyon, including type section (fig. 35 )

Older alluvium (Pleistocene).

Unconformity.

Meeke Mine Formation:

Estimated
thickness (feet)

Gravel, weakly consolidated; no discernible bedding; composed of subangular to rounded pebbles and cobbles of granitic rocks, hornfels, black schist, quartzite, and marble in matrix of gray-brown

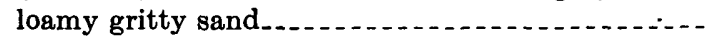
Clay shale, light gray to tan, less commonly pink, thin bedded, soft to moderately hard, somewhat siliceous or possibly tuffaceous; contains occasional layers few inches thick of impure limestone and soft buff fine-grained sandstone...............

Clay, gray, soft, crumbly when dry; no discernible bedding; exposed only in gullies . . ............

Gravel, similar to gravel at top of sequence, but in southwestern exposures bedding barely distinguishable through residual soil; in northwestern exposures includes several lenses as thick as $6 \mathrm{ft}$ of conglomeratic marl or limestone............

Total estimated thickness, Meeke Mine Formation. . . .

Unconformity.

Oso Canyon Formation.

Weakly to moderately consolidated sedimentary rocks near Antelope Canyon (fig. 11) about 1,650 feet thick questionably assigned to Meeke Mine Formation; composed of gray-white arkosic sandstone and conglomerate and a tongue of clay shale as thick as 250 feet. Conglomerate clasts mostly of granitic rocks; abundant clasts of marble and hornfels in lower part.

Smooth-shelled ostracods in shale and concretionary aggregates of calcareous algae(?) in basal limestone lens 1 mile southwest of Meeke mine indicative of fresh-water environment but not of age.

Great angular discordance with underlying upper Miocene formations suggests Meeke Mine Formation is Pliocene or younger, most probably upper Pliocene, possibly early Pleistocene.

\section{ROCK UNITS OF CENTRAL AREAS}

Nearly all of Tertiary rocks of central areas mapped as Tropico Group (Dibblee, 1958c, p. 136-138), a sequence of nonmarine sedimentary, pyroclastic, and volcanic rocks unconformable on pre-Tertiary crystalline rocks and unconformably overlain by Quaternary alluvial sediments in Antelope Buttes, Little Buttes, Rosamond Hills, Middle Buttes, Soledad Mountain, Bissell Hills, Castle Butte area, Kramer borate area, Kramer Hills, and Red Buttes (pl. 1). Maximum exposed thickness about 2,800 feet. Assemblage characterized by rapid lateral changes in lithology. 
Type section within half a mile west of MojaveTropico road in western Rosamond Hills 1-2 miles north of Tropico mine, or NE $1 / 4$ sec. 2 , T. 9 N., $R$. $13 \mathrm{~W}$. (Dibblee, 1958c, p. 136).

Tropico Group divided into units as shown on table 1.

\section{ANTEYLOPE BUTTE, ROSAMOND, AND MOJAVE AREAS GEM HILI FORMATION}

A dominantly pyroclastic sequence of silicic tuff, tuff breccia, and tuffaceous sandstone in Antelope and Little Buttes, Rosamond Hills, Middle Buttes, Soledad Mountain, and eastward to Bissell Hills (pl. 1); unconformable on Mesozoic quartz monzonite; includes associated silicic extrusive and intrusive volcanic rocks of Bobtail Quartz Latite Member. Named and described by Dibblee (1958c, p. 140; 1963, 164-187); type section at Gem Hill in western Rosamond Hills, 51/2 miles northwest of Rosamond, or S1/2 sec. $25, \mathrm{SE} 1 / 4 \mathrm{sec}$. 26 , and NE $1 / 4$ sec. 35, T. 10 N., R. 13 W.

Gem Hill Formation rests on red-weathered undulating surface of quartz monzonite. At Antelope Buttes, formation about 1,250 feet thick, composed of white bedded lithic tuff, tuff breccia and tuffaceous sandstone, and a lens of weathered basalt as thick as 20 feet (fig. 38). At Little Buttes about 800 feet of tuffaceous strata and some carbonate interbeds exposed.

At Gem Hill in Rosamond Hills, Gem Hill Formation about 1,290 feet thick (Dibblee, 1963, p. 168-169); thins eastward; composed of white to greenish-tan lithic tuff, tuffaceous sandstone, tuff breccia, and conglomerate of quartz latite detritus; also several thin basalt flows (figs. 39,40 ).
Tuff of Gem Hill Formation composed of devitrified glass shards, grains of feldspar and quartz, flakes of biotite, devitrified pumice lapilli, and fragments of tan and pink to brown rhyolite or quartz latite felsite and porphyry.

\section{BOBTAIL QUARTZ LATITE MEMBER}

Member consists of felsitic and porphyritic volcanic rocks of quartz latite or rhyolitic composition occurring as plugs, pods, and dikes intruded through preTertiary granitic rocks into stratified pyroclastic rocks of Gem Hill Formation and as short lenses of flow breccia within that formation in vicinities of Rosamond Hills, Middle Buttes, Soledad Mountain, and eastward to Bissell Hills (pl. 1) ; named after Bobtail mines, Soledad Mountain (Dibblee, 1958a, p. 140-141; 1963, p. 178-184); type locality, Soledad Mountain (secs. 6 and 7, T. 10 N., R. 12 W.).

Four facies of Bobtail Quartz Latite Member recognized and mapped (figs. 39-42) as follows: porphyry, felsite and porphyritic felsite, and perlite, all of intrusive origin, and felsite breccia, of probable extrusive origin.

Porphyry massive to faintly flow laminated, pink to brown; composed of phenocrysts of plagioclase (oligoclase), orthoclase (sanidine), quartz, hexagonal plates of hematite (after biotite?), and elongated black vugs (after hornblende?) in aphanitic groundmass (index of refraction 1.53) with disseminated hematite; phenocrysts make up 25-30 percent of rock. Forms large plug east of Soledad Mountain (fig. 42) and several dikes on Tropico Hill (fig. 39).

TABLE 1-Divisions of Tropico Group in western Mojave Desert and their presumed correlations

[See pl. $4 B$ for thickness and lithology of divisions]

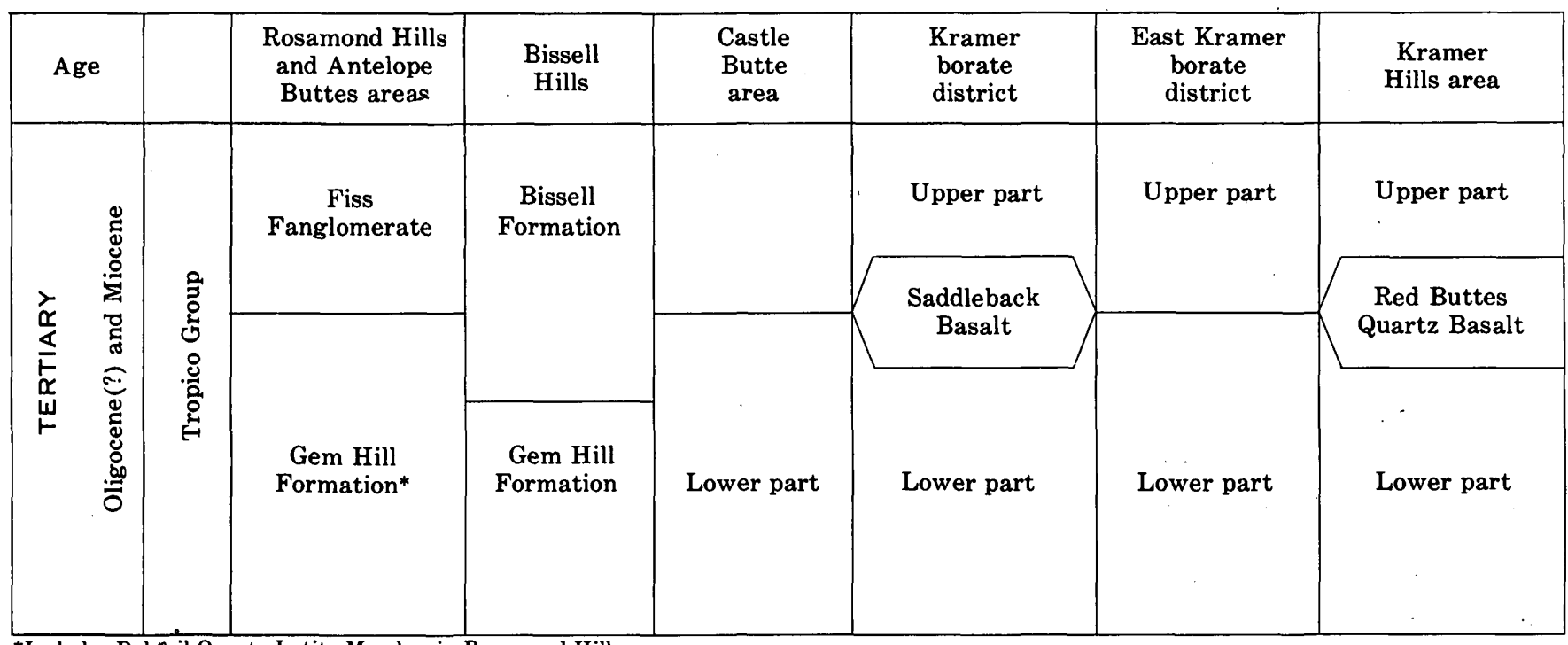

*Includes Bobtail Quartz Latite Member in Rosamond Hills area 

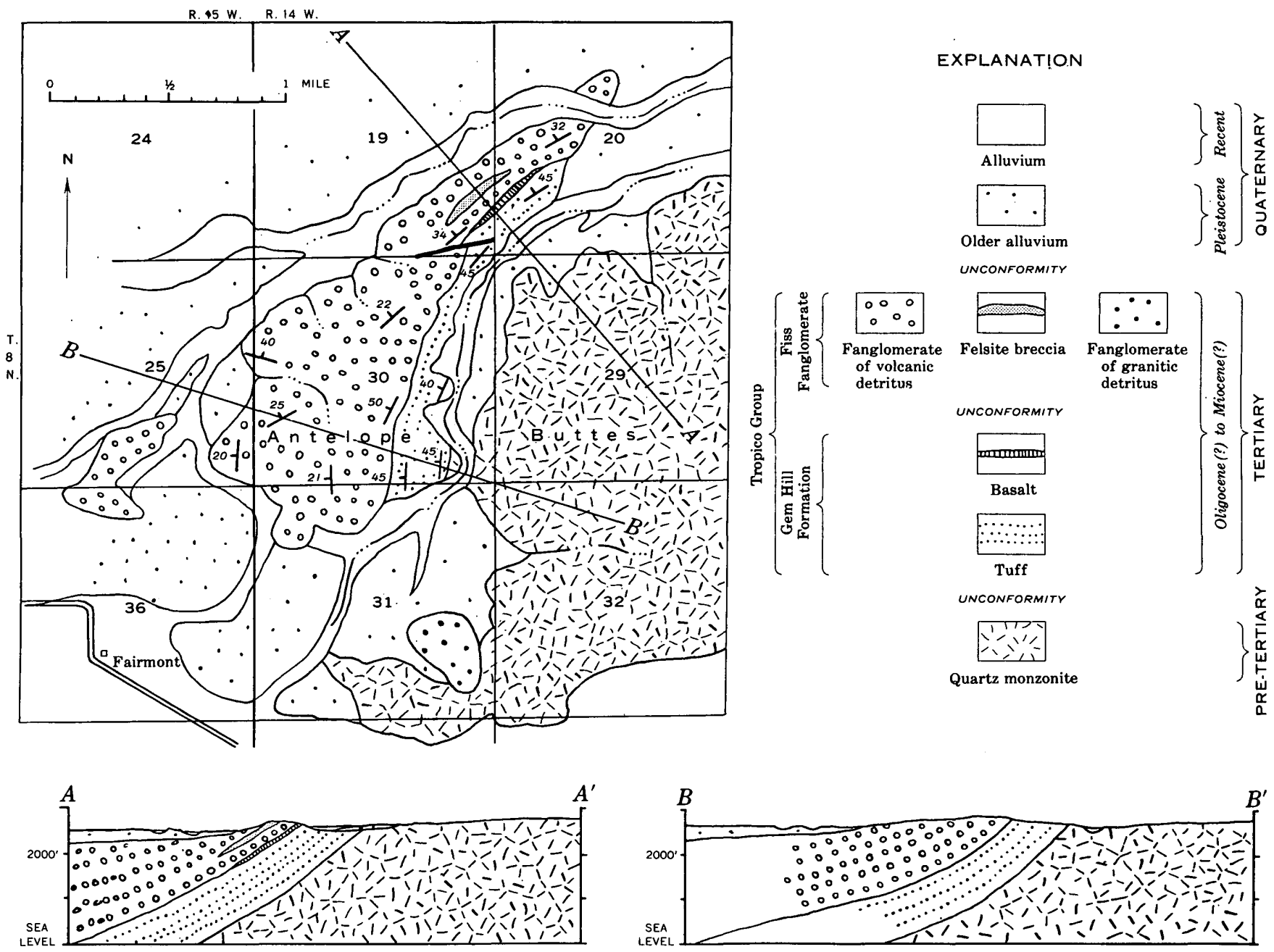

Figure 38.-Geologic map and sections of Antelope Buttes area.

Felsite and porphyritic felsite pink, red, brown to grayish green, $\tan$ to cream white, aphanitic to subvitreous, some containing phenocrysts that compose as much as 20 percent of rock of same minerals as those of porphyry facies. Most widespread facies of Bobtail Quartz Latite Member; similar to felsite of Neenach Volcanic Formation.

Perlite steel gray, vitreous; numerous curved fractures; forms chilled marginal border facies of some intrusive bodies of felsite and porphyritic felsite in Rosamond Hills and Soledad Mountain (figs. 40, 42).

Felsite breccia forms one extrusive and partly intrusive lenticular greenish-tan mass 1 mile south and southeast of Soledad Mountain (fig. 42), and another composed of brecciated dark-red felsite in Rosamond Hills 1 mile north and northwest of Rosamond (fig. 40).

Willow Springs Mountain and Tropico Hill each composed of pods and merging dikes of pink to buff felsite of Bobtail Quartz Latite Member that trend east and dip steeply south; intrusive into quartz monzonite and basal tuff and tuff breccia of Gem Hill Formation (fig. 39).

Middle Buttes composed of several pods and masses of buff felsite of Bobtail Quartz Latite Member elongated northwesterly, intrusive into quartz monzonite and overlying tuffaceous rocks of Gem Hill Formation (fig. 41); tuffaceous rock so hydrothermally altered as to be almost indistinguishable from intrusive quartz latite.

Soledad Mountain composed of several large pods of pink and green to buff felsite and porphyry of Bobtail Quartz Latite Member intrusive into pyroclastic rocks of Gem Hill Formation and underlying preTertiary rocks. Porphyry and felsite massive to flow laminated; flow laminae and fracture partings of each intrusion parallel to outer margins; porphyry intruded by felsite and therefore older (fig. 42). About 1,000 feet of Gem Hill Formation here exposed; composed 

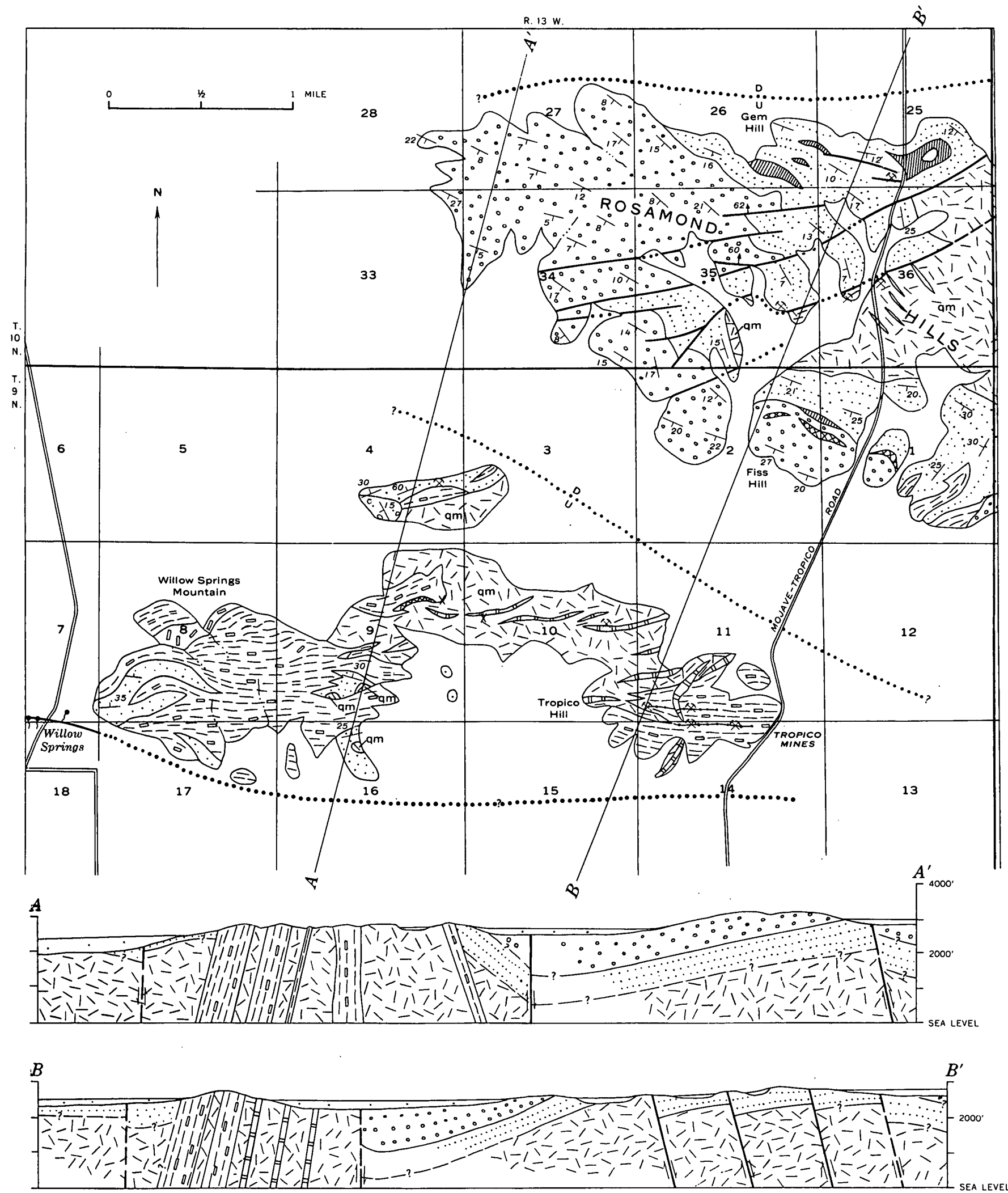

Fraure 39.-Geologic map and sections of Willow Springs Mountain, Tropico Hill, and western Rosamond Hills. Explanation on figure 40. 


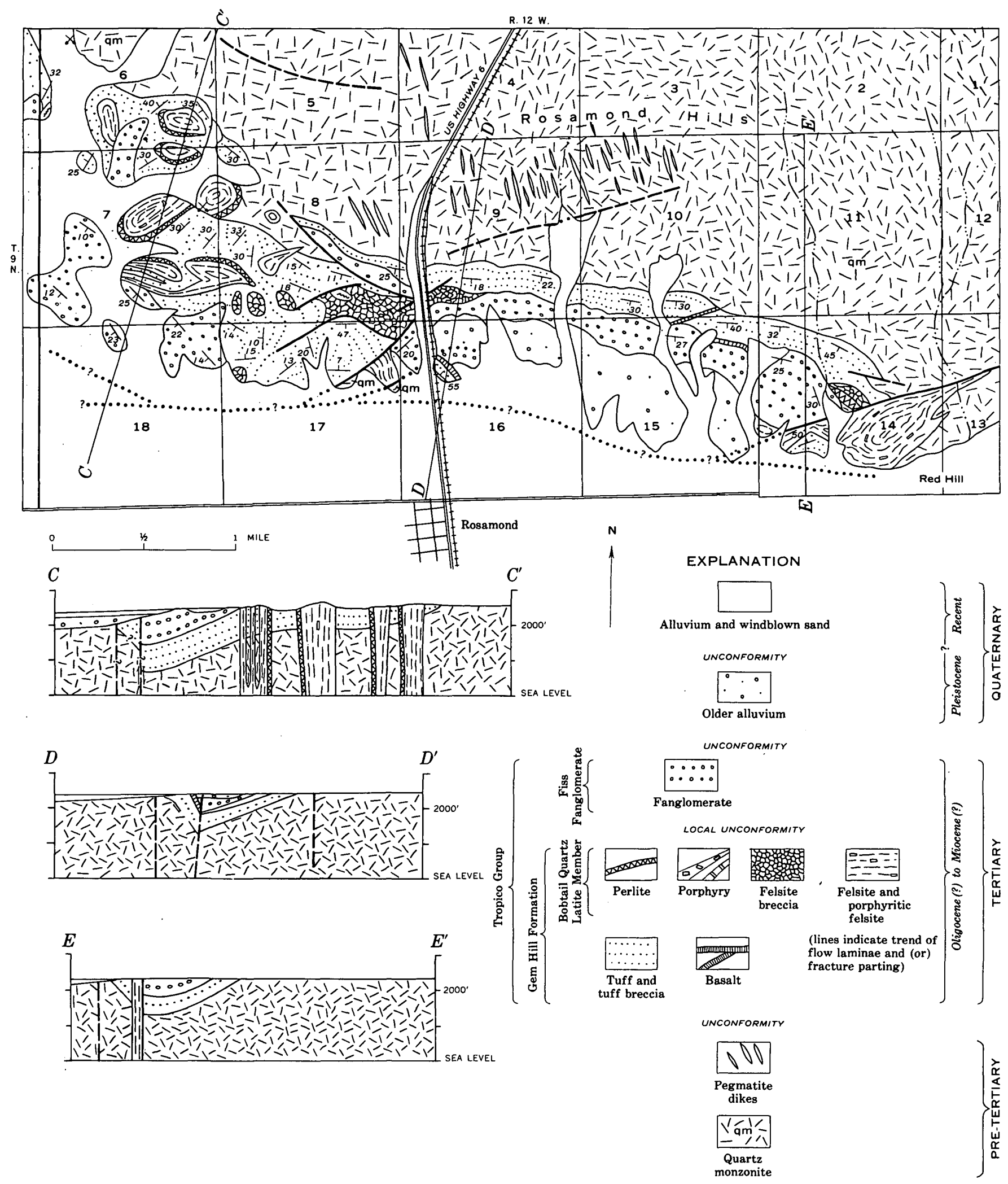

FIGURE 40.-Geologic map and sections of south-central Rosamond Hills. 

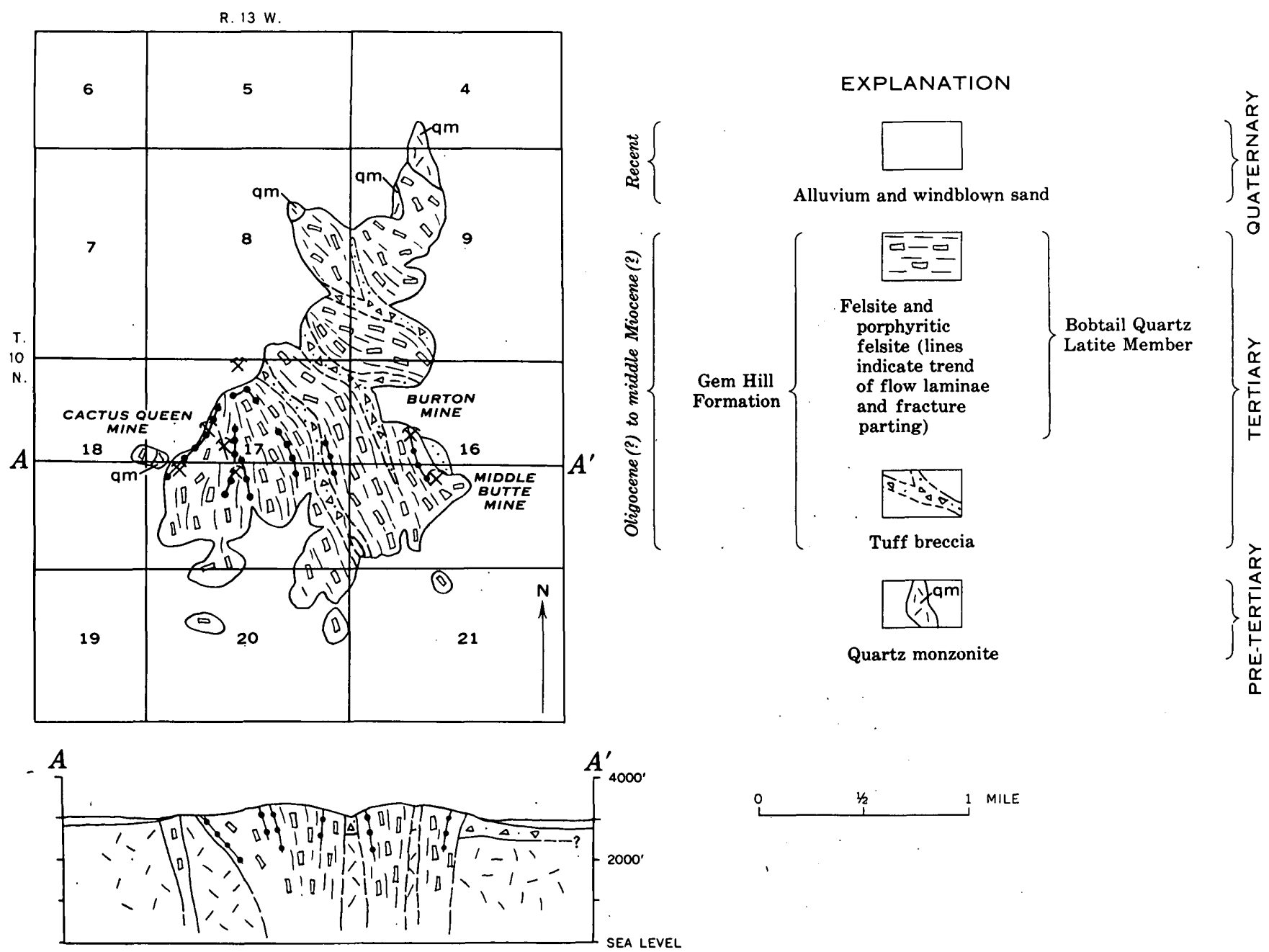

Figure 41.-Geologic map and section of Middle Buttes.

of greenish-white lithic tuff breccia, tuffaceous sandstone, felsite conglomerate, and basalt.

Gem Hill Formation unfossiliferous but similar in lithology and in stratigraphic position to Neenach, Kinnick and Pickhandle Formations and possibly to Vasquez Formation. Age may therefore be Oligocene to middle Miocene, but closer age assignment not possible.

\section{FISS FANGLOMERATE}

Coarse fanglomerate overlying Gem Hill Formation in Antelope Buttes and in Rosamond Hills; named after Fiss Hill in western Rosamond Hills (Dibblee, 1958 c, p. 141), described previously in detail (Dibblee, 1963, p. 187-191). Type section at Fiss Hill, 11/2 miles east of north of Tropico mines (sec. 1, T. 9 N., R. 13 W.).

Fiss Fanglomerate reddish brown, crudely bedded; composed of boulders, cobbles, and pebbles of felsitic and porphyritic rocks derived from Bobtail Quartz Latite Member, and few of granitic rocks; includes several small masses of brecciated felsite.
At Gem Hill, fanglomerate about 900 feet and gradational into underlying Gem Hill Formation; about 500 feet exposed at Fiss Hill; about 300 feet in foothills northeast of Rosamond and unconformable on Gem Hill Formation. About 1,700 feet exposed at Antelope Buttes.

Formation unfossiliferous, but presumably of Miocene age, probably correlative with lower part of Oso Canyon Formation as suggested by similarity in lithology and stratigraphic position, as well as to coarse alluvial facies of Bopesta Formation in Tehachapi area, Barstow Formation in Gravel and Mud Hills, and Punchbowl Formation south of Palmdale, all partly or entirely of Miocene age.

\section{BISSELL FORMATION}

A fluviatile and lacustrine sedimentary sequence overlying Gem Hill Formation in Bissell Hills (fig. 43) after which formation was named (Dibblee, 1958c, p. 141-142; 1963, p. 191). Type section exposed from 

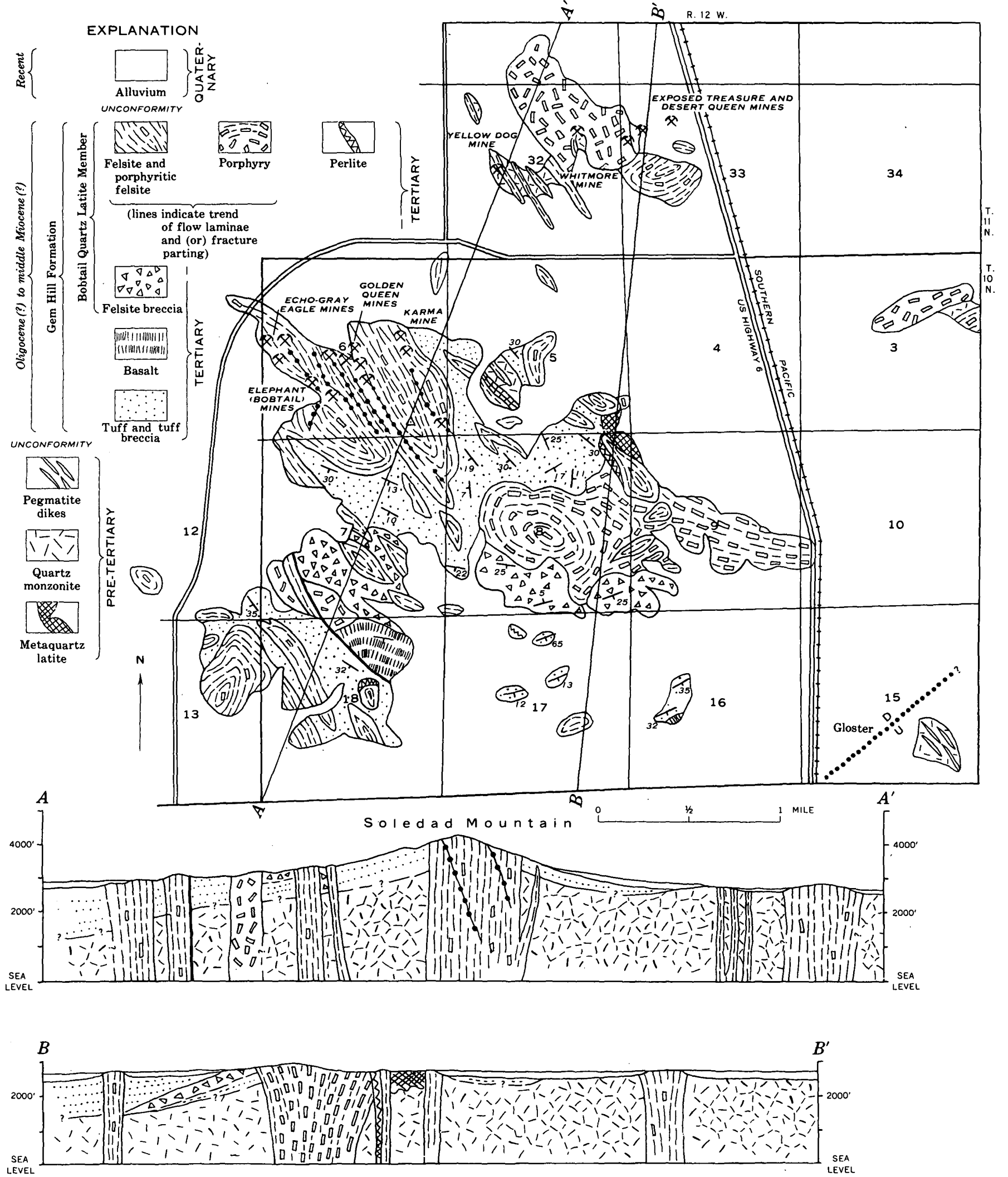

Figure 42.-Geologic map and sections of Soledad Mountain area. 
Bissell magnesite pits across low strike ridge to north in Bissell Hills ( $\mathrm{N} 1 / 2$ sec. $11, \mathrm{~T} .10 \mathrm{~N}$., R. 11 W.).

Bissell Formation about 760 feet thick at type locality; composed of three members which are, in ascending order (fig. 43), carbonate and shale, clay, and sandstone.

Carbonate and shale member overlies tuff of Gem Hill Formation; 145 feet thick at type locality but thickens to maximum of about 330 feet 1 mile west; composed of light-gray clay shale grading to nearly white thin-bedded semisiliceous or tuffaceous shale; many interbeds as thick as 3 feet of light- to yellowish-gray hard carbonate rock ranging from dolomite to limestone; northwest of magnesite pits include some thin platy layers of hard siliceous shale and gray chert.

Clay shale member exposed only at and near magnesite pits; about 140 feet thick; composed of greenish-gray to slightly reddish gray soft, crumbly, slightly gypsiferous clay shale; at magnesite pits lower part includes several strata 1-10 inches thick of soft white magnesite.

Sandstone member exposed only south of magnesite pits; about 475 feet thick; composed of alternating gray clay shale, light-gray arkosic sandstone, and gray conglomerate containing cobbles and pebbles of gran- itic rocks, aplite, pegmatite, and a few pinkish-brown felsitic volcanic rocks; sequence includes a bed 6 feet thick of white tuff 325 feet above base; clay shale predominates in lower part, sandstone and conglomerate in upper part; overlain unconformably by older alluvium.

Bissell Formation unfossiliferous; presumably correlative with or older than Fiss Fanglomerate, late Miocene(?). Lower part possibly lacustrine facies of upper part of Gem Hill Formation. Bissell Formation tentatively considered to be Miocene in age.

CASTLE BUTTE, BORON, AND KRAMER HILLS AREAS UNNAMED LOWER PART OF TROPICO GROUP

Unnamed lower part of Tropico Group is a terrestrial sequence exposed as isolated outcrops in vicinities of Castle Butte, Kramer borate district, Kramer Junction area, and Kramer Hills (pl. 1), unconformable on quartz monzonite and metamorphic rocks; overlain by middle and upper parts of Tropico Group.

Composed of tuffaceous and carbonate rocks, chert, shale, sandstone, conglomerate, breccia, and basalt. Tuffaceous rocks, white to greenish-tan; range from fine-grained tuff to lithic tuff breccia and tuffaceous sandstone; presumably of quartz latite composition and apparently identical to tuffaceous rocks of Gem Hill Formation.

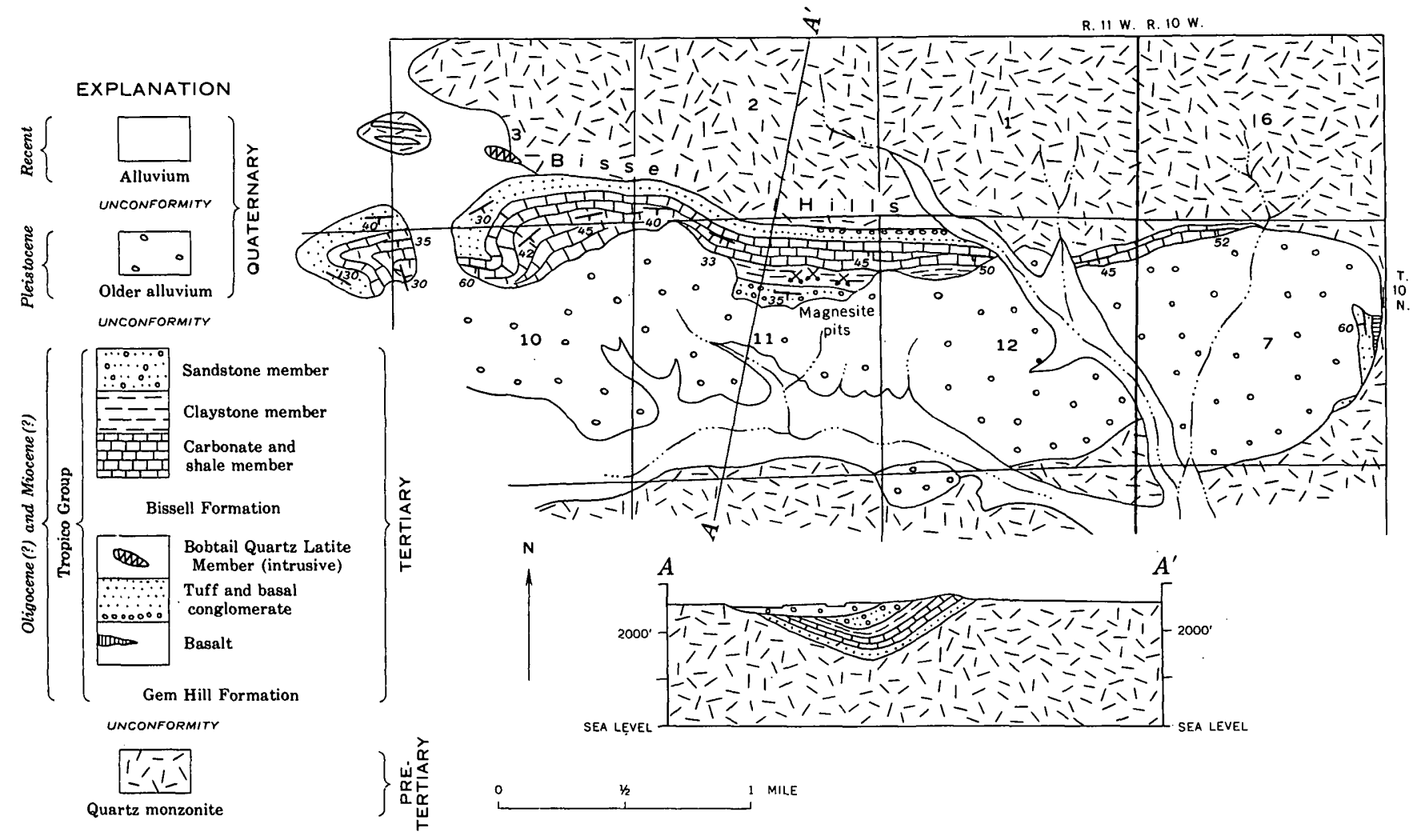

FTGURE 43.-Geologic map and section of Bissell Hills area. 
Carbonate and chert strata are as much as several feet thick; occur in shale. Carbonate strata, yellowish-gray to nearly white, very hard, bedded, aphanitic; range from limestone to dolomite in composition; some layers have nodules of gray chert Chert layers, translucent gray to nearly black, locally mottled with brown, green, yellow, red; very hard but brittle and closely fractured; range from opal to impure chalcedony in composition.

Shale is tuffaceous, siliceous, or clayey; tuffaceous shale nearly white, soft, thin bedded to massive; siliceous shale, cream white, hard, platy, coarsely laminated, slightly to moderately procellaneous; clay shale gray, rarely green or red, soft, crumbly, argillaceous to silty, micaceous.

Sandstone light gray to buff, friable to locally moderately hard, bedded, fine to coarse grained, arkosic, commonly micaceous. Conglomerate, composed of pebbles, cobbles, or boulders in matrix of arkosic sandstone; clasts mostly of granitic rocks, locally of diorite, quartzite, and metavolcanic detritus. Breccia composed of granitic detritus, locally of dioritic material.

Basalt black, weakly coherent, massive; of fine- to medium-grained diabasic (ophitic) texture; locally slightly amygdaloidal; composed of $40-50$ percent plagioclase (labradorite), 25-30 percent augite, 10-15 percent olivine (partly altered to iddingsite and antigorite?), 1-4 percent magnetite and ilmenite, small amounts of secondary minerals (chlorite, hematite, limonite, calcite, chalcedony).

Lower part of Tropico Group exposed nearly 2,000 feet thick; sequence chacterized by rapid lateral changes of thickness and lithology, but lowest beds mostly pyroclastic, upper beds mostly sedimentary.

Lower part of Tropico Group prominently exposed in Castle Butte area (fig. 44) as follows in descending order:

Lower part of Tropico Group (sec. 26 and N3/2 sec. 35, T. 32 S., R. $38 E$.)

Fanglomerate.

Unconformity.

Lower part of Tropico Group:

Basalt

Sandstone, hard, thick-bedded, coarse-grained, gritty; contains minor thin layers of sandy shale; forms prominent hill. . . . . . . . . . . . . . . . . .

Clay shale, gray; contains few hard platy layers as thick as 2 in.; also a 5 -ft-thick layer of sandstone

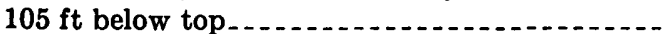

Siliceous shale; uppermost $3 \mathrm{ft}$ composed of hard ledge-forming dark chalcedonic chert and occasional limestone beds. 50
Lower part of Tropico Group (sec. 26 and N3/2 sec. 35 T. 32 S., R. 38 E.)-Continued

Lower part of Tropico Group-Continued

Tuff

Basalt; lenses out to west and east.

(feet)
Thickses

Sandstone, medium-grained, tuffaceous........ 13

Tuff........................ 260

Sandstone, coarse-grained, gritty; lenses out to east_.

Tuff

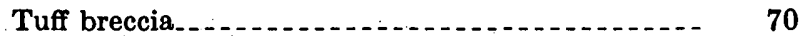

Tuffaceous shale, siliceous shale, and clay shale, interbedded; tuffaceous shale predominating ..- $\quad 45$

Basalt; lenses out to east and west............. 0-15

Tuff breccia.......... 10

Siliceous shale

. Tuff breccia and minor interbedded tuff _....... 117

Andesite breccia, green to reddish-brown, unstrati-

fied; lenses out to west. . . . . . . . . . . . . . . 0-190

Total thickness exposed (exclusive of two lower basalt lenses) ................. 1,440

Unconformity.

Quartz monzonite.

Pyroclastic lower unit exposed nearly 10 miles eastnortheast of Castle Butte (fig. 45), with sequence as follows:

Lower part of Tropico Group (SW1/4 sec. 5 and SE1/2 sec. 6, T. 32 S., R. $40 \mathrm{E}$.)

Quaternary older alluvium.

Unconformity.

Lower part of Tropico Group: Thick-

Lithic tuff breccia, thick-bedded, greenish-yellowish- $($ (feet)

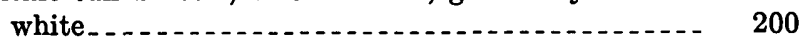

Fanglomerate of quartz monzonite boulders as much as $2 \mathrm{ft}$ in diameter.

Quartz latite, mafic, gray, fine-grained, massive.... 5

Bentonite and tuff .......................... 30

Total thickness exposed...

Unconformity.

Quartz monzonite.

In areas between Castle Butte and Saddleback Mountain, and in Muroc and Stonehouse Hills northwest of Boron, lower part of Tropico Group (referred to Rosamond Series of former usage, by Gale, 1946, p. 350357 , pl. 52) ranges from 100 to about 1,200 feet in thickness; composed of lithologic units as shown on figures 45-48.

In low hill just south of Kramer borate mines (fig. 46), about 200 feet of exposed strata, presumably of 
lower part of Tropico Group, are as follows in descending order:

Lower part of Tropico Group (SE1/4 sec. 23, SW1/4 sec. 24, T. 11 N., R. $8 \mathrm{~W}$.)

Quaternary (?) granitic cobble-boulder conglomerate.

Unconformity.

Lower part of Tropico Group:

Tuffaceous shale; contains a few limestone beds as $\begin{gathered}\text { ness } \\ (\text { feet }\end{gathered}$

much as $1 \mathrm{ft}$ thick. .

Limestone, cherty, in beds as much as $5 \mathrm{ft}$ thick; interbedded tuffaceous shale........

Arkosic sandstone....

Basalt

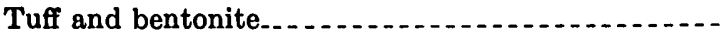

Arkosic sandstone, coarse-grained............ 0-10

Total thickness exposed . . . . . . . 210

Unconformity.

Quartz monzonite.

In large alluviated area north of Kramer Junction (or Four Corners), gray coarse granitic cobble conglomerate and breccia presumably of lower part of Tropico Group exposed at only one place, just west of U.S. Highway 395, 4 miles north of Kramer Junction (fig. 49); similar conglomerate penetrated in three core holes to south drilled for U.S. Geological Survey; deepest penetration of 1,650 feet into conglomerate by hole 4 (fig. 49, sections; table 3 ).

In Kramer Hills and vicinity, lower part of Tropico Group ranges from about 500 to 2,000 feet in exposed thickness; overlain by shale of upper part of Tropico Group, or unconformably by Red Buttes Quartz Basalt (figs. 50, 51) ; five lithologic members recognizable in various parts of Kramer Hills (Dibblee, 1960d, p. 90-96), as follows in descending order:
Member
5. Clay shale, locally tuffaceous.
4. Carbonate rocks and interbedded shale.
3. Sandstone and shale, including lens of granitic breccia.
2. Carbonate rocks and interbedded shale.
1. Tuff, sandstone, and conglomerate.

Flows of basalt present in members 1, 3, 4, and 5 and lens of dacite vitrophyre in member 1 (fig. 50). Exposed sequences of lower part of Tropico Group in various parts of Kramer Hills disconformably or unconformably overlain by Red Buttes Quartz Basalt; unconformably overlie pre-Tertiary quartz monzonite or metamorphic rocks. Sequences as follows in descending order:

Lower part of Tropico Group exposed in northern part of Kramer Hills just east of U.S. Highway $\$ 95$ (secs. 39 and $\$ 4, T .10 \mathrm{~N}$., R. 6 W.)

Member

5. Clay shale; contains 2 beds (5-10 ft thick) of dolomite.

Basalt; contains 2 beds (5-10 ft thick) of dolomite

Clay shale; contains 3 layers (5-13 ft thick) of thin-bedded dolomite and shale; includes 2 tongues of basalt that wedge in from north..

4. Dolomite; interbedded siliceous shale and some chert. ................................... 25

3. Clay shale; at least $5 \mathrm{ft}$ of basalt near middle (member largely concealed)

2. Dolomite and interbedded tuffaceous shale, rare chert. . . .

1. Tuff

Sandstone, gritty, arkosic _...

Basalt . . . . . . .

Conglomerate; cobbles as much as $1 \mathrm{ft}$ in diameter of pegmatite, aplite, and granitic rocks in arkosic sandy matrix . $0-5$

Total exposed thickness . . . . . . . 1, 463

Lower part of Tropico Group exposed in central part of Kramer Hills, east of U.S. Highway 995 (secs. 3 and 4, T. 9 N., R. 6W.)

Member

Tuffaceous shale.

Thickness

Basalt. Includes a wedge as thick as $30 \mathrm{ft}$ of tuffaceous shale lensing in from northwest; top about $65 \mathrm{ft}$ below top of basalt. . .......

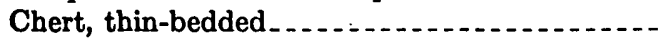

Clay shale, gray to tan; contains $5 \mathrm{ft}$ of dolomite

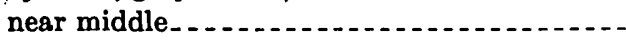

Basalt (and shale?) . . . . . . . . .

4. Dolomite; some lenses of black chert..........

3. Clay shale and sandstone; some basalt near middle (member largely concealed) .........

2. Limestone; interbedded shale and chert......

1. Sandstone, tan, arkosic; contains scattered pebbles and cobbles of pre-Tertiary andesitic

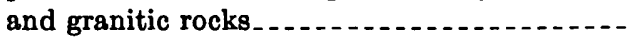

Dacite vitrophyre, extrusive or intrusive(?) lens. . 2 . 150

Sandstone, like that above. Conglomerate(?); no outcrops but loose pebbles and cobbles of pre-Tertiary quartzite, andesitic and granitic rocks. Tuff exposed in 80 -ft shaft to southeast............... $100 \pm$

Total exposed thickness, exclusive of dacite vitrophyre (estimated) .............. 1, 321 

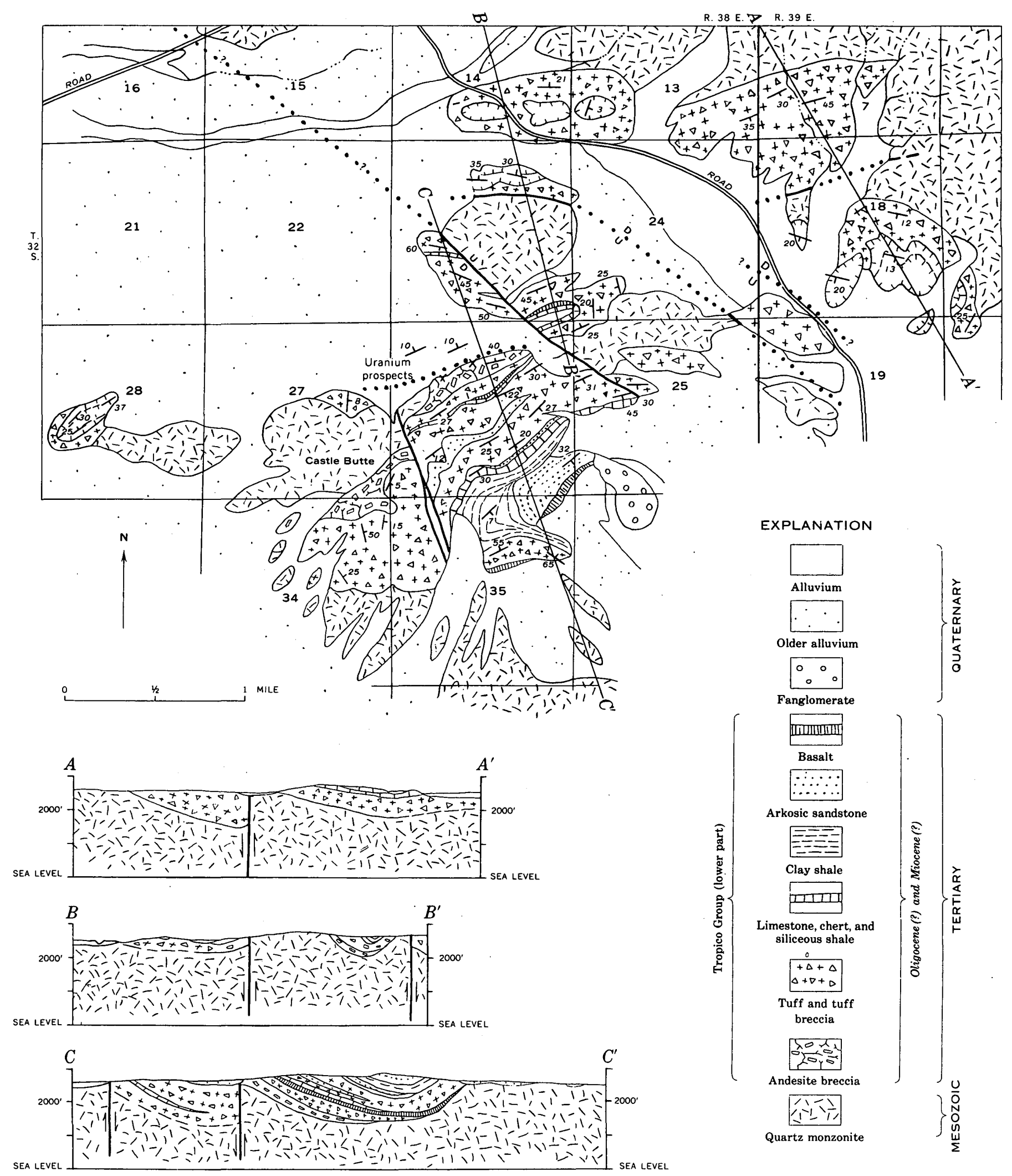

Fraure 44.-Geologic map and sections of Castle Butte area. 


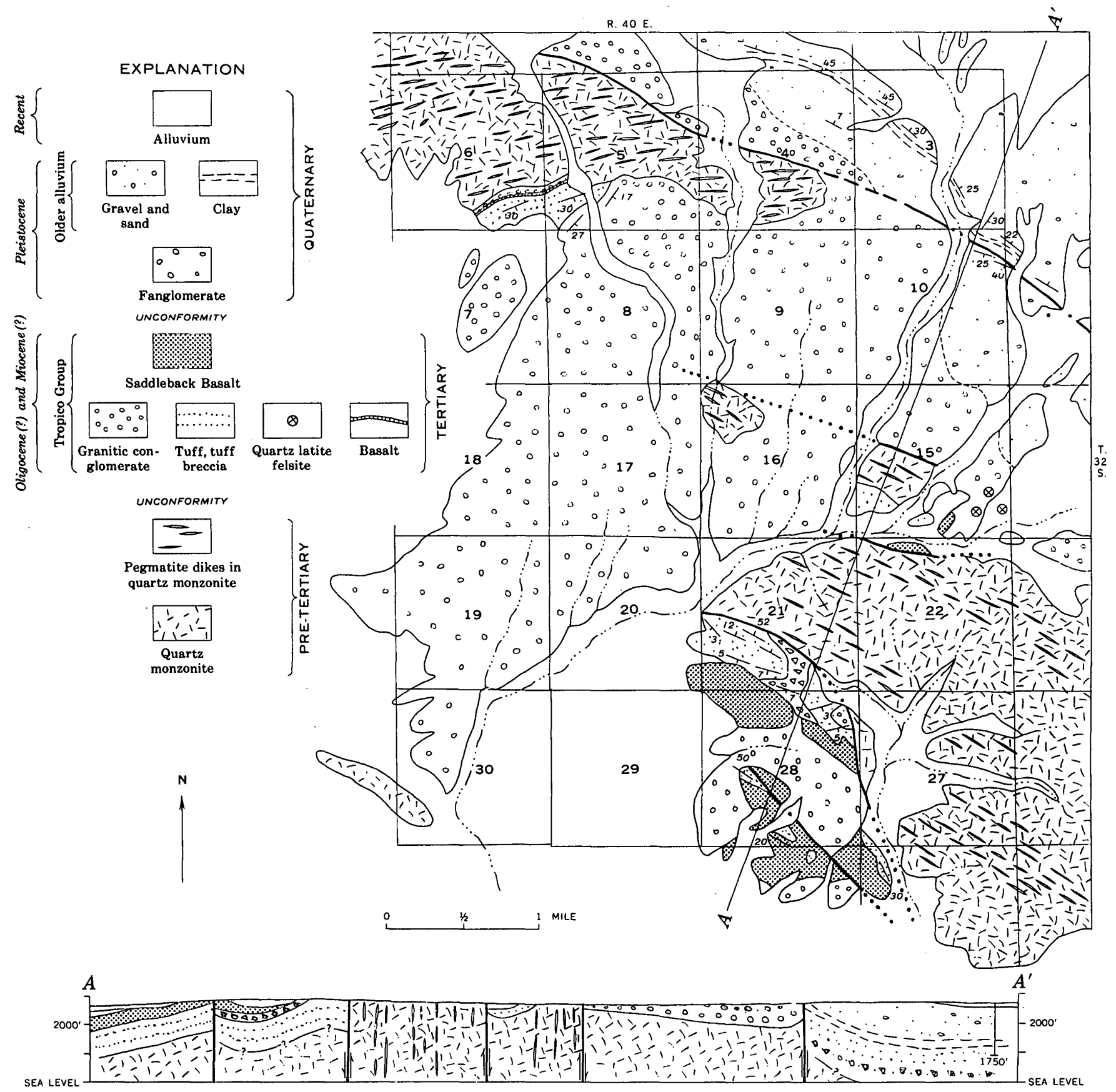

Frgure 45.-Geologic map and section of hills east of Castle Butte. 


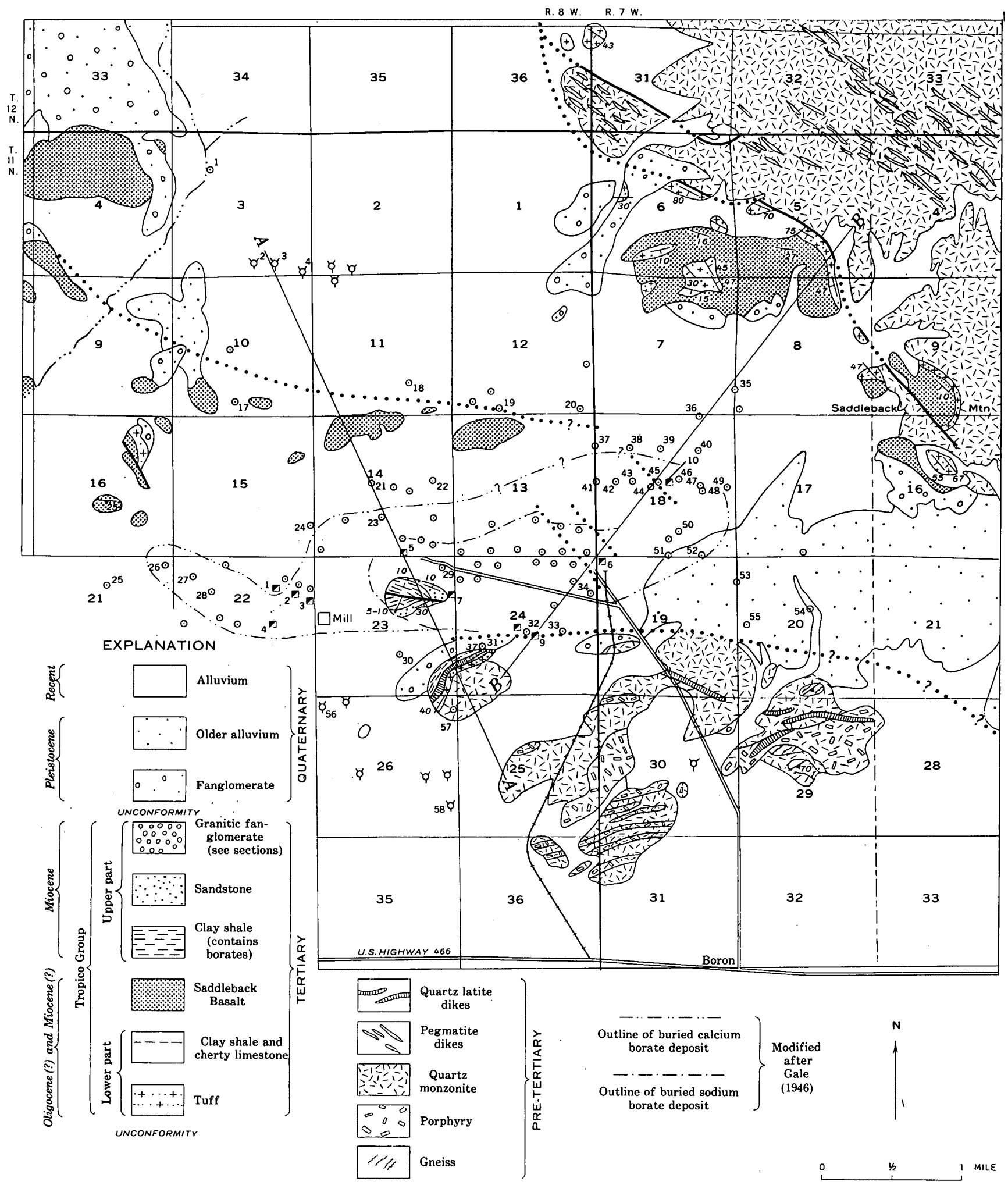

FIgURE 46.-Geologic map of Kramer borate district. 


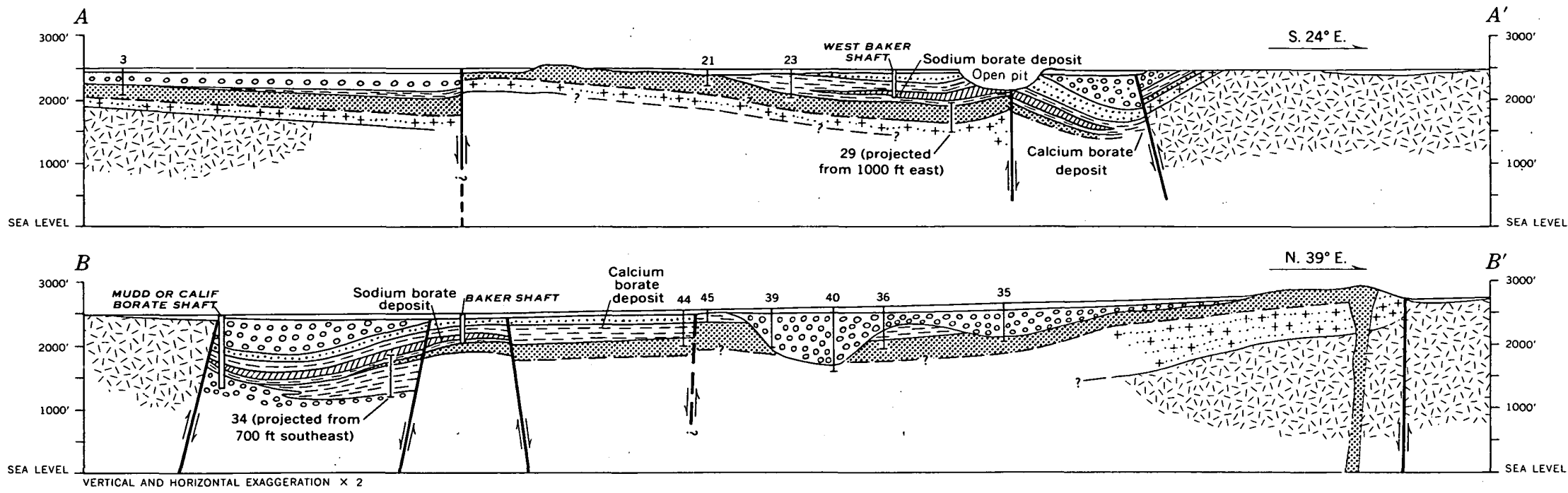

Figure 47.-Sections of Kramer borate district. Locations of sections are shown on figure 46. 
Lower part of Tropico Group exposed in southeastern part of Kramer Hills east of U.S. Highway 395 (SE1/4 sec. 11, NW1/4 sec. 14, T. 9 N., R. 6 W.)

Eastward along strike, member 5 becomes overlapped by Red Buttes Quartz Basalt; breccia of shattered quartz monzonite and diorite appears as lens as thick as $200 \mathrm{ft}$ at top of member 3 ; member 2 thickens southeast ward to as much as
(fig. 50); total exposed thickness about 1,650 feet in sec. 13, T. 9 N., R. 9 W.
Member

4. Dolomite, white; interbedded gray clay shale and thin layers of white magnetite.......

3b. Basalt; some clay shale in basal part

2. Limestone; minor interbedded shale and chert.-.

1.
5. Clay shale. $\ldots . . .$.

3a. Sandstone, light-gray
Thickness 456

221

476

215

43

160

Total exposed thickness 1,571
Lower part of Tropico Group exposed in southwestern part of Kramer Hills just west of U.S. Highway 395 (sec. 16 and SEY4 sec. $17, T .9 N$., R. $6 \mathrm{~W}$.

Northwestward along strike, members 1 and 2 lap out against pre-Tertiary basement rocks (fig. 50)

\section{Member}

5. Clay shale, gray to red

Sandstone, grit and pebbles of granitic rocks and Tertiary rhyolitic rocks; some clay shale..........

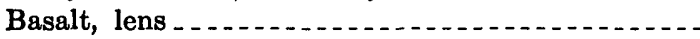

Sandstone and clay shale (mostly concealed) ....-

2. Limestone and interbedded shale and chert ......

1.
Thicknes

115

180

45

$0-45$

80

18

Tuff.

Total thickness exposed (approximate) -.-
Lower part of Tropico Group probably of early Miocene age or possibly of older Tertiary age, as indicated by position stratigraphically below upper part of Tropico Group that contains early middle Miocene fossils at Boron open pit mine. Pyroclastic lower unit of lower part of Tropico Group in Castle Butte and Kramer borate area and member 1 in Kramer Hills lithologically similar to and presumably correlative with Gem Hill Formation in Rosamond Hills. Sedimentary strata and basalt flows that constitute rest of lower part of Tropico Group presumably correlative with Bissell Formation of Bissell Hills.

\section{DACITE}

At Desert Buttes, southwest of Castle Butte, dacite forms three isolated small volcanic plugs surrounded and partly covered by Quaternary alluvium, but presumably intrusive through quartz monzonite exposed to south; rock light pink gray, felsitic; flow laminae and fracture parting are concentric around central core and dip vertically or steeply inward at each plug.

At Haystack Butte, dacite forms single plug in quartz monzonite; rock massive, felsitic; contains small scattered phenocrysts of plagioclase (oligoclase), quartz, biotite, hornblende, and potassic feldspar, in order of decreasing abundance.

In Kramer Hills, dacite occurs as several masses in and near sec. 35 , T. $10 \mathrm{~N}$., R. $6 \mathrm{~W}$., probably intrusive into lower part of Tropico Group along fault at northern margin of hills (fig. 50); rock generally similar to that of Haystack Butte, but pale pink gray and lacks hornblende. Dacite also present as lens of vitrophyre in member 1 of lower part of Tropico Group in sec. 3, T. 9 N., R. 6 W. (fig. 50 ).

Dacite presumably same age as lower part of Tropico Group, but possibly younger.

\section{SADDLEBACK_BASALT}

One or more flows of basalt that form middle part of Tropico Group in Kramer borate distriot; exposed discontinuously from Saddleback Mountain northwestward for 7 miles, and westward for 15 miles (pl. 1). Occurs under borate-bearing shale throughout Kramer borate mines except in extreme southern part; also struck in water wells below Quaternary gravel under alluviated valley within 5 miles north of Kramer borate mines. Named and described by Gale (1946, p. $346-350$, pl. 52) and referred by him to Ricardo Formation (lower Pliocene); redefined as a formation and assigned to Pliocene(?) (Dibblee, 1958c, p. 142).

Type locality at Saddleback Mountain (in sec. 9, T. 11 N., R. 7 W.; see fig. 46).

Northwestward from Saddleback Mountain, basalt about 200 feet thick, composed of several flows; rests unconformably (?) on pyroclastic rocks of lower part of Tropico Group (figs. 45, 46). At Stone House and Muroc Hills, Saddleback Basalt probably about 300 feet in maximum thickness and composed of several fine-grained flows. Overlies lower part of Tropico Group, probably unconformably (fig. 48).

Under Kramer borate mines and westward, Saddleback Basalt composed of several flows, in places separated by shale or sandstone (fig. 47); total thickness of basalt more than 400 feet, but not completely penetrated by any well.

Basalt black, massive, aphanitic or very fine grained to ophitic (finely diabasic); aphanitic facies commonly weathers reddish brown. Rock composed essentially of plagioclase (calcic labradorite), augite, and olivine (largely altered to antigorite and limonite?), iron oxides, common scattered very small phenocrysts of labradorite; scattered amygdules of zeolites, calcite, or silica are other constituents.

Saddleback Basalt now considered to be early Miocene in age, as suggested by probable conformable 

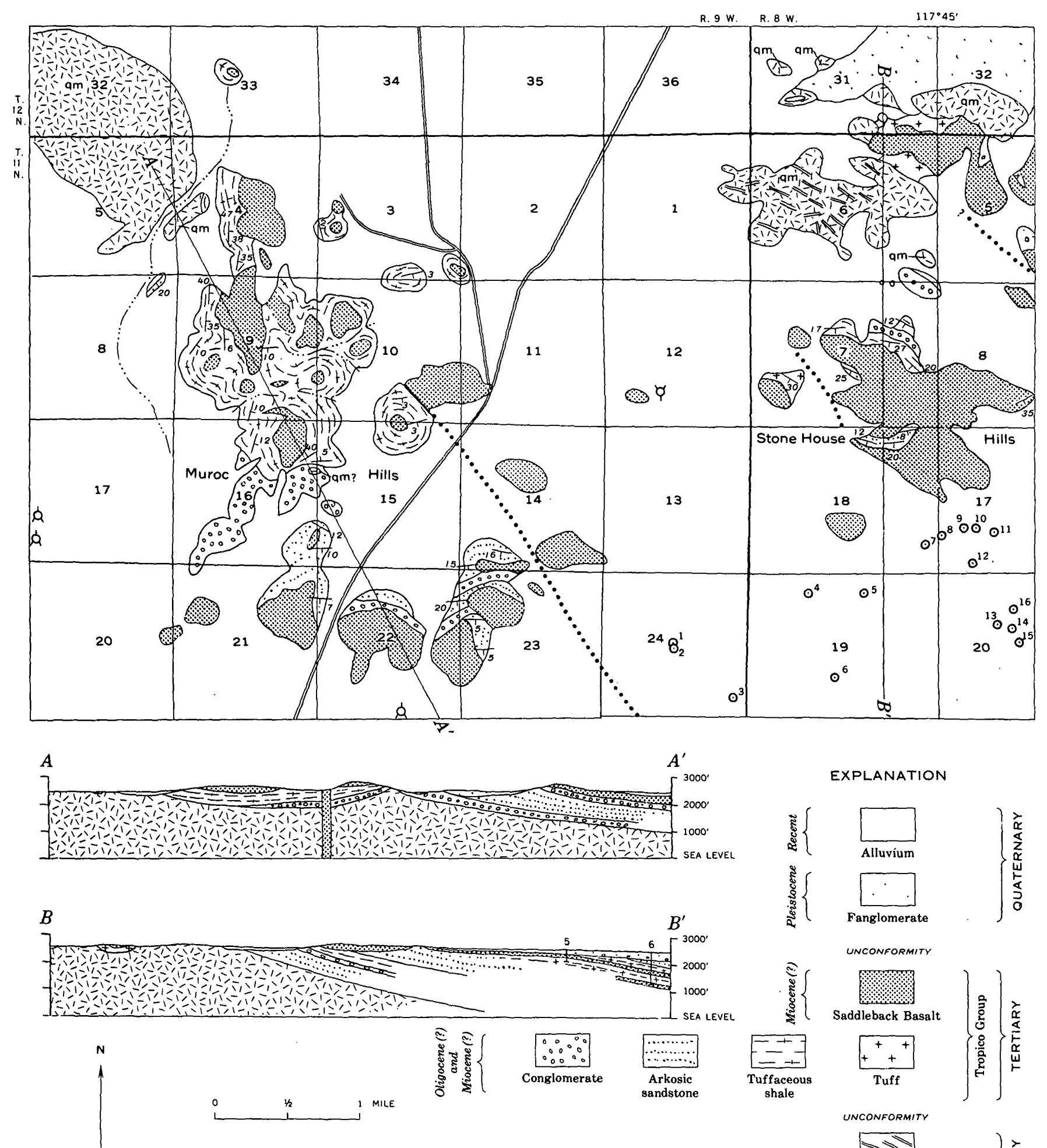

FraUre 48.-Geologic map and sections of Muroc and Stone House Hills. 

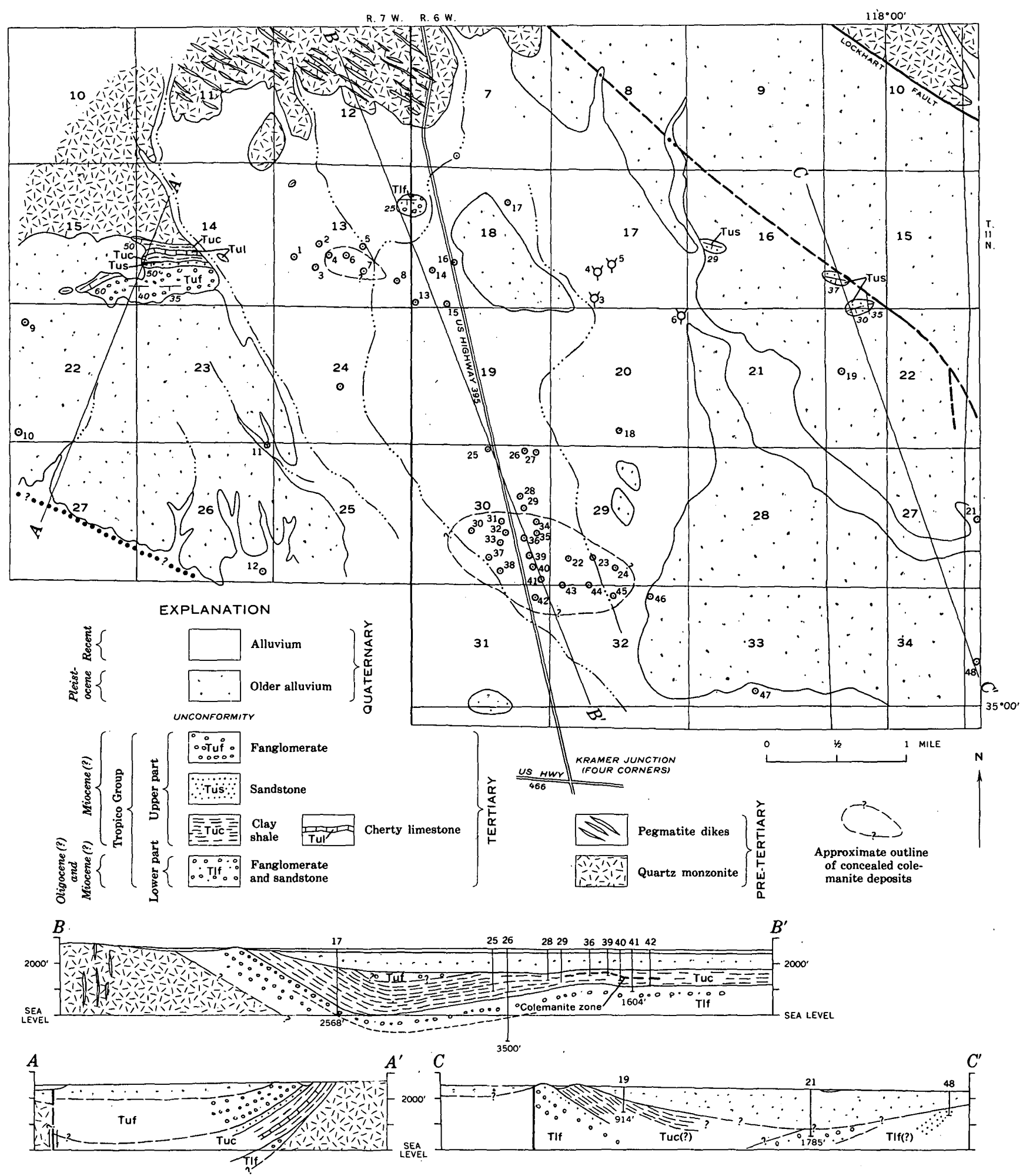

FIGURE 49.-Geologic map and sections of Kramer Junction or east Kramer area. 
relation to overlying beds that contain early middle Miocene ventebrate remains at Boron pit, or possibly older Tertiary.

\section{RED BUTTES QUARTZ BASALT}

One or more flows of quartz basalt form middle part of Tropico Group in Kramer Hills (pl. 1); also exposed at and near Red Buttes (the type locality, sec. 5, T. 8 N., R. 6 W.), for which it was named, and assigned to the Pliocene(?) (Dibblee 1958c, p. 142143 ; 1960d, p. 101-102); described and mapped as quartz andesite by Bowen (1954, p. 78, 83-84, pl. 1).

At Red Buttes, quartz basalt composed of several lava flows totaling about 300 feet in thickness rests directly on quartz monzonite; overlain unconformably by Quaternary fanglomerate. In Kramer Hills, quartz basalt forms one or several flows that total 360 feet in maximum thickness overlying lower part of Tropico Group with slight unconformity (figs. 49, 50).

Basalt black on fresh surface, massive, hard, nonvesicular; in places somewhat brecciated; aphanitic to very fine grained; contains scattered small rounded phenocrysts $1 \mathrm{~mm}$ or less in diameter of quartz; smaller rectangular ones of plagioclase (labradorite); groundmass composed of labradorite, augite, diopside, glass, hypersthene, greenish-brown hornblende, and magnetite, in order of decreasing abundance (Bowen, 1954, p. 83-84).

Quartz basalt now considered to be early Miocene age or older; probably correlative with Saddleback Basalt, as suggested by similar stratigraphic position and unconformable relationship to underlying lower part of Tropico Group.

\section{UNNAMED UPPER PART OF TROPICO GROUP}

A sequence composed mainly of clay shale, sand. stone, and conglomerate that conformably overlies lower or middle parts of Tropico Group in Kramer borate district, Kramer Junotion area, and Kramer Hills. Not given formation status because of incomplete and poor exposures and uncertainty of correlation from area to area.

In Kramer borate mines north of Boron, sequence revealed by mine workings and exploratory test holes described in detail by Gale $(1946$, p. $335,339-346$, pls. $51,52)$ and referred by him to Ricardo Formation (lower Pliocene) as used by Merriam (1914). Sequence conformably overlies Saddleback Basalt; about 800 feet in maximum thickness. Composed of three lithologic units as follows in ascending order: clay shale containing borate deposits, sandstone, and fanglomerate.
Clay shale unit, described in detail as "Kramer Lake Beds" by Gale (1946, p. 335, 339-346, pls. 51, 52), light dusty gray; in borate mines about 320 feet thick: contains all the borate deposits, mostly in middle part (as described on p. 126); overlies Saddleback Basalt throughout mine area except along southern margin where it overlies granitic-cobble conglomerate (fig. 59) ; grades upward through thin interbeds into overlying sandstone unit, as seen in open pit of borate mines.

Sandstone unit about 80 feet thick at Mudd borate (Western Borax) mine (Gale, 1946, fig. 4); about 150 feet thick at U.S. Borax Co. open pit; light grayish brown, friable, bedded, arkosic. Grades upward into overlying fanglomerate.

Fanglomerate unit found only in drill holes in southern parts of mine area, penetrated to depth of 640 feet in shaft of Mudd borate (Western Borax) mine (Gale, 1946, p. 339, fig. 4) ; composed of unsorted granitic cobbles and pebbles in gray arkosic sand matrix; maximum thickness estimated about 500 feet.

In foothills a few miles north of Kramer and Kramer Junction sedimentary sequence presumably of upper part of Tropico Group partly exposed, and penetrated in several test holes in adjacent alluviated valley (fig. 49); sequence similar to that of Kramer borate district, but thicker, and rests directly on granitic bedrock. Most complete sequence exposed 5 miles northwest of Kramer Junction (fig. 49) as follows in descending order:

Upper part of Tropico Group (S1/2 secs. 14 and 15, T. 11 N., R. $7 W$., 5 miles northwest of Kramer Junction)

Older alluvium.

Unconformity.

Upper part of Tropico Group:

Granitic fanglomerate; composed of unsorted subrounded cobbles and boulders of granitic rocks, Thickpegmatite, and aplite in gray arkosic matrix; occa- (feet) sional coarse gritty sandstone. . . . . . . . . . . . . 350

Sandstone, light-gray, fine- to coarse-grained, micaceous, arkosic; upper $10 \mathrm{ft}$ includes several layers as much as 9 in. thick containing pea-size pumice fragments; includes some interbedded micaceous shale in lower part.

Clay shale, poorly exposed $\ldots . . . . . . . . .$.

Limestone, gray, massive, sandy; includes some shale and chert; much brecciated. . ................

Shale, clayey to tuffaceous; in places semisiliceous; thin-bedded, mostly gray, but locally white, yellow, orange, red, pink, purple; contains occasional thin platy beds of limestone......

Total exposed thickness.

Unconformity.

Quartz monzonite. 


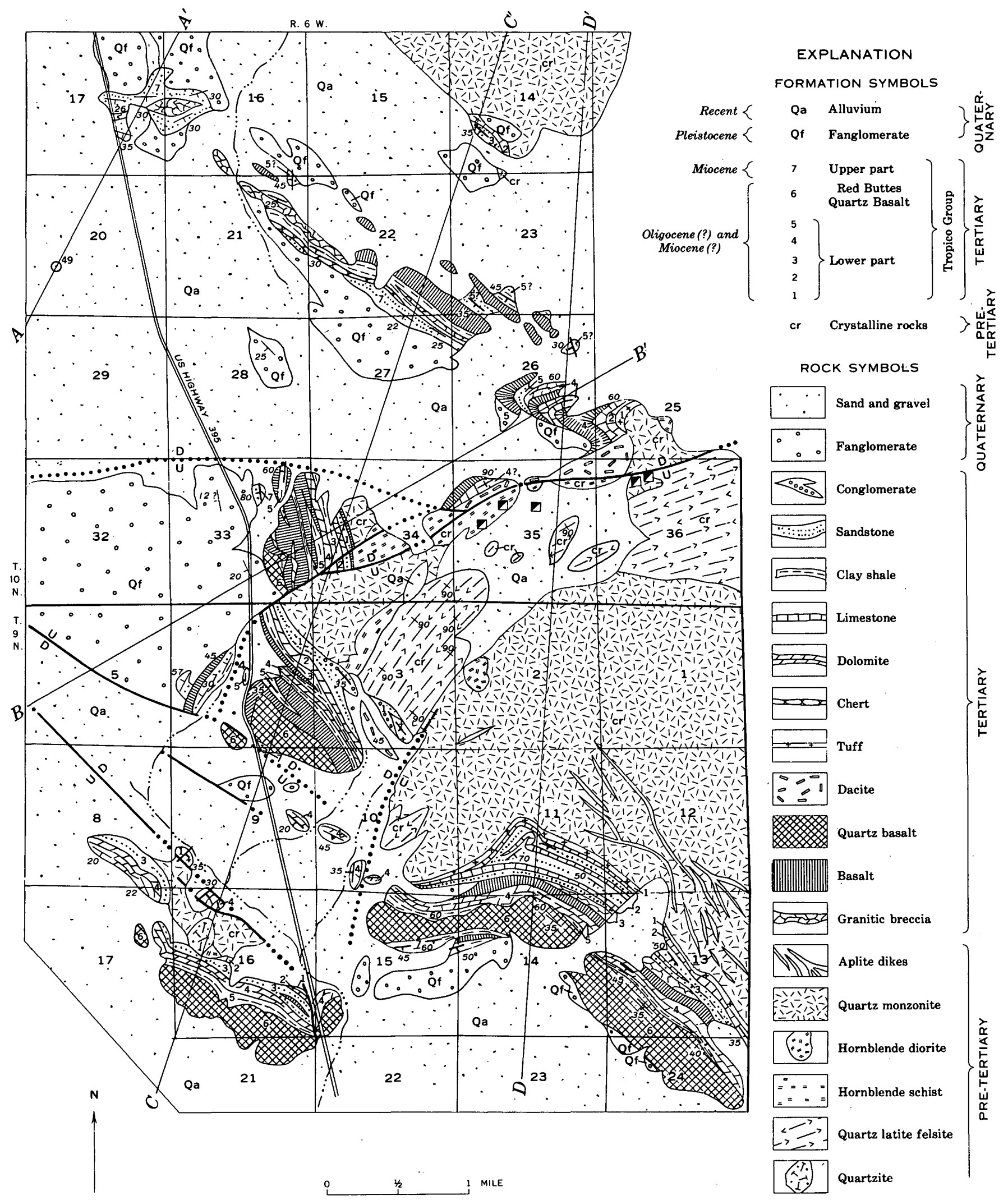

FigURE 50.-Geologic map of Kramer Hills. 

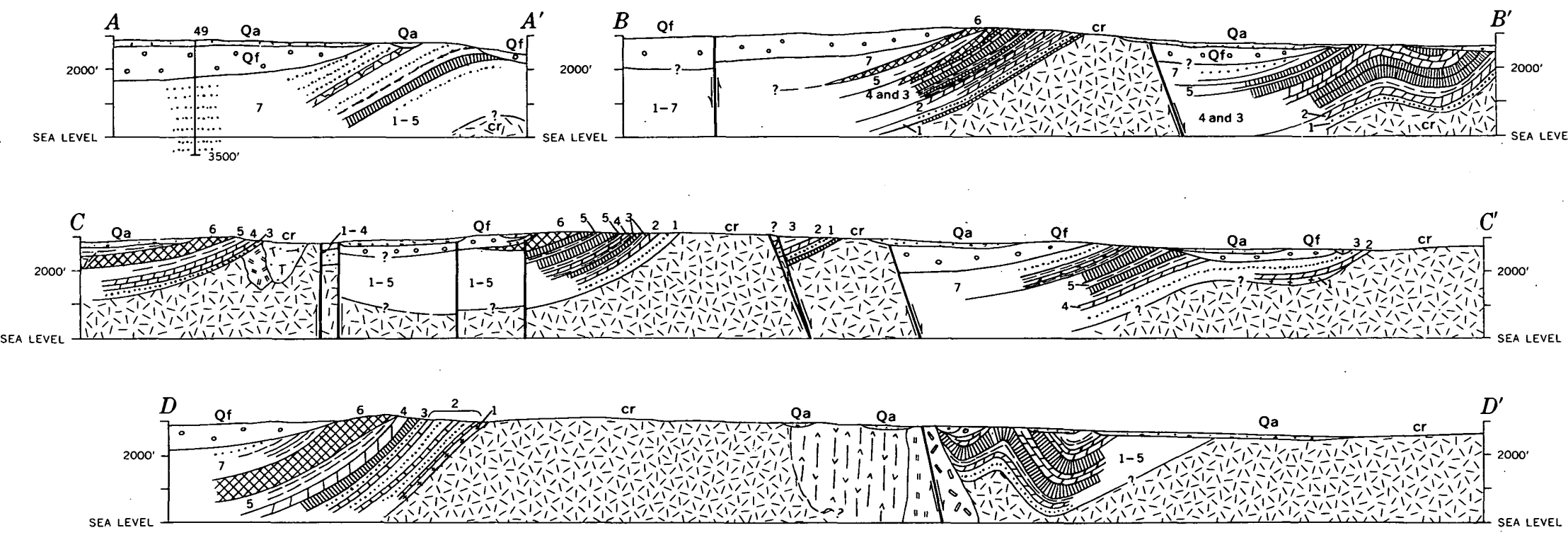

Figure 51.-Sections of the Kramer Hills. Locations of sections are shown on figure 50. 
In test holes in secs. 22 and 30, T. 11 N., R. 7 W., shale unit at least 1,000 feet thick; contains thin layers as thick as 4 inches of colemanite near middle, but no limestone or chert; fanglomerate may be 1,500 feet thick in test hole in SW1/4 sec. $22, \mathrm{~T} .11 \mathrm{~N} ., \mathrm{R} .7 \mathrm{~W}$. (fig. 49).

In low knolls in secs. 21 and 22 , T. 10 N., R. 6 W., uppermost basalt flow of lower part of Tropico Group overlain by shale and sandstone sequence presumably of upper part of Tropico Group (fig. 50) ; about 800 feet exposed just east of U.S. Highway 395. Sequence as follows in descending order:

Upper part of Tropico Group (secs. 21 and 22, T. 10 N., R. 6 W., 5 miles southeast of Kramer Junction)

Fanglomerate.

Unconformity.

Upper part of Tropico Group:

Thickness (feet)

Sandstone, light-gray, arkosic

Chert, opaline to chalcedonic, gray-white to tranglucent gray ; commonly streaked with yellow, brown, red, black; contains silicified roots of reeds, palms(?) and other plants....

Clay shale, gray, micaceous . .

Granitic breccia (shattered quartz monzonite) .... -

Sandstone, light-gray, arkosic

Total exposed thickness, upper part of Tropico Group

Lower part of Tropico Group:

Basalt

Upper part of Tropico Group overlies Red Buttes Quartz Basalt; composed of micaceous gray clay shale, interbedded arkosic sandstone, and occasional thin flows of olivine basalt, unconformably overlain by Quaternary older alluvium (figs. 49, 50, 51). In southeastern part of Kramer Hills in W1/2 sec. 14, T. 9 N., R. $6 \mathrm{~W}$., about 800 feet exposed (mapped as "upper lakebeds, Miocene" by Bowen, 1954, fig. 43, p. $78)$.

Mammalian fossils found in upper part of Tropico Group from a horizon within 21-foot-thick sequence of $\tan$ sandstone and siltstone about 200 feet above top of borate ore body at Boron open pit mine by U.S. Borax and Chemical Co. This fauna, known as the Boron fauna, believed to be of early middle Miocene (early Hemingfordian) age; is older than the faunas from the Barstow Formation (Merriam, 1919), and close to the fauna from the Tick Canyon Formation of Jahns $(1939$; 1940) in Soledad basin (R. H. Tedford, University of California, Riverside, written commun. to S. J. Muessig, U.S. Borax and Chemical Co., April 28, 1964).

This fauna indicates that upper part of Tropico Group is older than Pliocene age to which this unit was tentatively assigned (Gale, 1946, p. 335, 339-346, pls. 51, 52; Dibblee, 1958a ; 1958c, p. 138, 142). If so, it may be correlative with the unfossiliferous lower third of the middle and late Miocene Barstow Formation of the Mud Hills of which the lacustrine facies is lithologically similar, or it may be older.

\section{LIMESTONE}

A low hill 2 miles west of Castle Butte is capped by about 50 feet of thick-bedded dark-gray limestone that rests on about 150 feet of tan-white tuff, presumably of lower part of Tropico Group (fig. 44). Limestone contains locally numerous concentric aggregates of calcareous algae (?).

Limestone formerly thought to be part of lower part of Tropico Group (Dibblee, 1958b), but it contains diatom remains that suggest Pliocene age, as reported by Kenneth E. Lohman (written commun., March 2, 1953). If this limestone is of Pliocene age, it is younger than the Tropico Group, and may be correlative with the Horned Toad Formation (Pliocene) of the Horned Toad Hills.

\section{ROCK UNITS OF EASTERN AREAS \\ BARSTOW AREA \\ UNNAMED_SEDIMENTARY ROCKS}

Unnamed sedimentary rocks of lacustrine and fluviatile origin exposed 5 miles south of Barstow; also as several isolated outcrops near Barstow and Lenwood; described by Bowen (1954, p. 79-80) and Dibblee (1960d).

Sedimentary sequence exposed 2 miles west, 1 mile north, and 2 miles northwest of Barstow (fig. 5) consists of 5-20 feet of soft gray clay and pebbly sandstone resting on weathered surface of gneiss and in turn overlain by $10-30$ feet of unevenly bedded darkgreenish-gray to ocher-yellow ferruginous dolomite or limestone, in places cherty.

According to Bowen (1954, p. 22, 104-105, pl. 1), limestone outcrop 2 miles northwest of Barstow yielded poorly preserved gastropod and echinoid debris of probable late Paleozoic (possibly Pennsylvanian) age; limestone asigned by him to Oro Grande Formation, interpreted to have been thrust from northeast. However, fossils reported (specimens are lost, and repeated searches have been made for more but none ever found) either reworked or not certainly identified and therefore unreliable. Furthermore, limestone 

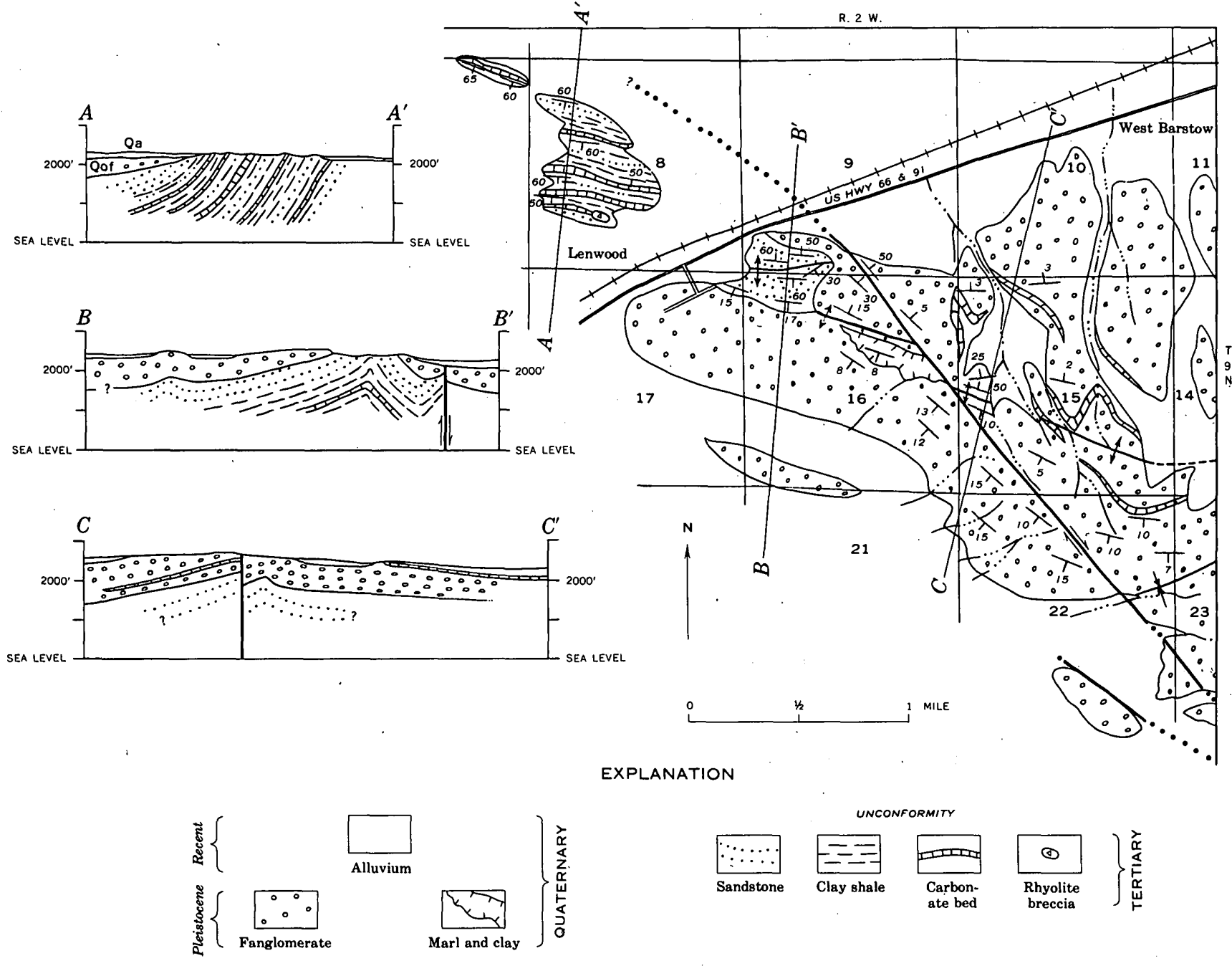

Fraure 52.-Geologic map and sections of Lenwood area.

unmetamorphosed, totally devoid of any metamorphic crystalloblasts (T. H. McCulloh, University of California, Riverside, oral commun., 1963), lithologically similar to that of other outcrops of Tertiary age near Barstow and east of mapped area. Therefore outcrop now regarded as Tertiary in age, unconformable on Waterman Gneiss (fig. 5).

Near Lenwood (fig. 52), at least 2,000 feet of sequence exposed; here mainly gray clay shale, some interbedded gray micaceous sandstone, and several beds as much as 5 feet thick of hard tan dolomite or limestone.

In exposure 5 miles south of Barstow, unnamed fanglomerate (Rosamond of Gardner, 1940, p. 278281, pl. 2) on Daggett Ridge overlain unconformably by an unfossiliferous sequence 1,500 feet thick. Extends eastward beyond border of mapped area and described by Gardner (1940, p. 289-290, pl. 2) as "Campbell's Lake beds." Basal 150 feet composed of gray-white tuff of glass shards; remainder of green to red siltstone and sandstone. Separated from overlying Quaternary gravel by white marly limestone.

\section{DACITE}

Dacite exposed as large mass 7 miles northwest of Barstow, as several intrusive plugs at Barstow and in Waterman Hills (fig. 5), and as isolated outcrop 7 miles southwest of Barstow and also east of Barstow beyond east border of mapped area.

Dacite of these areas pink to pinkish gray, porphyritic, massive to flow laminated. Phenocrysts make up 20-30 percent of rock and are plagioclase (sodic andesine), quartz, and biotite; aphanitic groundmass is mainly plagioclase, sanidine, quartz: and scattered magnetite (Bowen, 1954, p. 87-88).

Northwest of Barstow, dacite mass intrusive into pre-Tertiary rocks; in Waterman Hills, dacite intrusive into pre-Tertiary rocks and Pickhandle Formation; rock massive in both areas. 
At Barstow, dacite plugs surrounded by Quaternary alluvial sediments; characterized by concentric flow laminae parallel to outer walls of each plug as indicated on figure 5. Beyond east border of mapped area, dacite intrusive into pyroclastic and sedimentary rocks similar to those of probable Oligocene or Miocene age. If so, dacite probably Pliocene(?) but possibly Miocene in age.

\section{JACKHAMMER FORMATION}

A discontinuous thin basal sedimentary and volcanic formation exposed only in eastern Mud Hills; unconformably on quartz monzonite; overlain by Pickhandle Formation. Named and described by McCulloh (1952, p. 107-109) from exposures at type locality at Jackhammer Gap east of Mud Hills (Dibblee, 1967), and officially adopted for use in this report.

About 150 feet in maximum thickness, best exposed in Owl Canyon (fig. 55) ; lower part 30-100 feet of red arkosic sandstone and siltstone; in places sandstone contains smoothly rounded cobbles of quartzite and granitic rocks; upper part 5-20 feet of bedded white tuff, overlain by 5-30 feet of vesicular basalt. Half a mile east of Owl Canyon, formation composed of lens as thick as 50 feet of gray limestone; farther east composed of granitic-boulder conglomerate.

Formation unfossiliferous; older than Pickhandle Formation; presumably Oligocene or early Miocene in age.

\section{PICKHANDLE FORMATION}

A sequence of mostly pyroclastic rocks exposed in Waterman Hills 4 miles north of Barstow, in Mud Hills, Opal Mountain-Upper Black Canyon area, and Gravel Hills (pl. 1) ; rests on eroded, weathered surface of pre-Tertiary crystalline rocks, except in eastern Mud Hills where it conformably overlies Jackhammer Formation; formation first recognized in Calico Mountains, where mapped and named by McCulloh (1952, p. 114-125) after Pickhandle Pass, the type locality, in Calico Mountains (Dibblee, 1967). Officially adopted for use in this report.

In Waterman Hills (fig. 5), formation is about 3,700 feet thick; composed of about 800 feet of tuff breccia at base; overlain by about 400 feet of dark. red-brown flow breccia of rhyolite or dacitic felsite that extends from larger volcanic mass to southeast; in turn overlain by about 2,300 feet of tan tuff breccia containing felsitic fragments; at top about 200 feet of gray conglomerate of granitic and dacitic cobbles.

In Mud Hills (figs. 54, 55) on north flank of Barstow syncline, formation about 2,800 feet thick; composed of conglomerate, tuff breccia, granitic and rhyo- litic breccia, sandstone, and andesite, in somewhat variable stratigraphic order as shown, and as described below.

Conglomerate as thick as 600 feet forms lower part of formation; gray, poorly bedded, composed of boulders and cobbles of quartz monzonite in friable matrix of arkosic grit or sandy tuff breccia. Includes some thin lenses of gray to red arkosic sandstone.

Tuff breccia forms middle part of formation, as much as 1,150 feet thick; also present in upper part; white, greenish white to buff white, thick bedded, fine to medium grained; contains angular fragments of brown porphyritic andesite and lapilli of soft devitrified pumice.

Granitic breccia and rhyolitic breccia (fig. 55) together form as much as 1,100 feet of upper part of formation. Granitic breccia composed of shattered quartz monzonite; forms thick massive resistant lightgray to reddish-gray lenses, some as thick as 500 feet. Rhyolitic breccia composed of shattered massive white rhyolitic felsite; forms local thinner white lenticular intercalations within granitic breccia.

Andesite forms lenticular flow at top of formation near Barstow-Goldstone road and on south flank of Barstow syncline 2 miles west of that road; massive, brown, porphyritic; contains phenocrysts of plagioclase and basaltic hornblende in aphanitic groundmass.

Rhyolitic breccia (fig. 54) in northwestern part of Mud Hills about 500 feet thick, rests on quartz monzonite; indistinctly bedded, yellowish brown; composed of angular fragments of tan rhyolitic felsite.

In vicinity of Williams pumicite quarry 6 miles east of Opal Mountain, formation about 250 feet thick; composed of bedded white to orange-buff pumiceous tuff ; pumice fragments as large as 3 inches in tuffaceous matrix. Overlain by rhyolitic flow breccia of Opal Mountain Volcanic Formation.

In Opal Mountain-Black Canyon area (fig. 53), Pickhandle Formation about 2,800 feet thick; composed mostly of white bedded tuff ; lower part associated with rhyolitic intrusions and flow breccias of Opal Mountain Volcanic Formation; contains two basalt flows, one as much as 250 feet thick, and conglomerate lenses, as much as 50 feet thick, of either volcanic or granitic detritus, and a 10-foot lens of chert and limestone. Tuff medium to fine grained; contains grains of quartz, feldspar, flakes of biotite, lapilli of devitrified pumice, and fragments of rhyolitic felsite. Grades upward through thin intercalations into shale of overlying Barstow Formation in Black Canyon. 


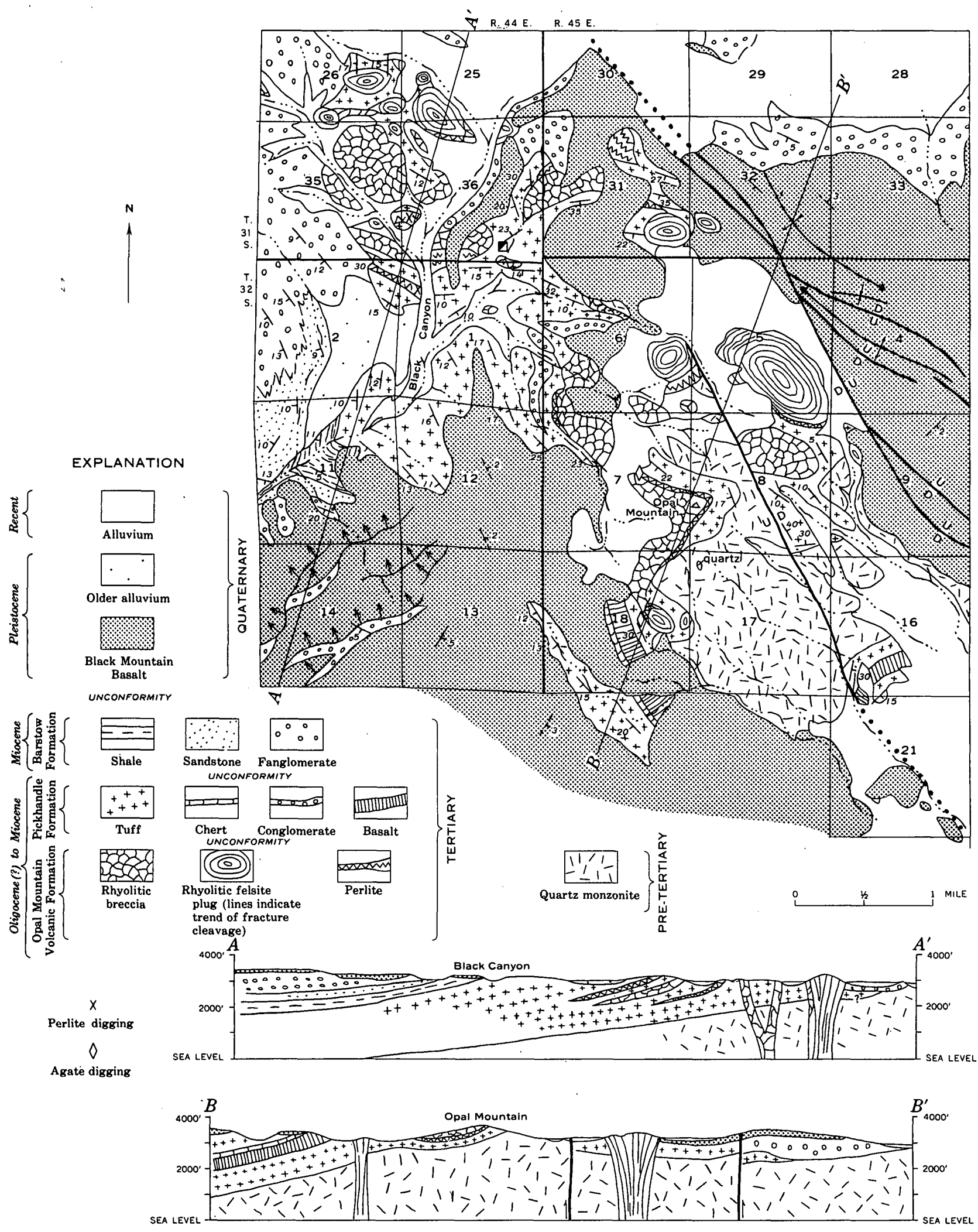

Figure 53.-Geologic map and sections of upper Black Canyon and Opal Mountain area. 
In Gravel Hills (fig. 56), formation composed essentially of white tuff associated with rhyolitic flow breccia and intrusions of Opal Mountain Volcanic Formation as in Opal Mountain-Black Canyon area; total thickness of tuff about 700 feet; includes several lenses as much as 200 feet thick of conglomerate of granitic cobbles and boulders; basal part includes some conglomerate of perlite detritus.

Southwest from Black Mountain and Gravel Hills, Pickhandle Formation presumably thins out beneath Harper Valley as indicated by its total absence above pre-Tertiary crystalline rocks in several test holes on and near Harper (Dry) Lake (table 3), and in hills southwest of Harper Valley.

Formation unfossiliferous, but older than unconformably overlying Barstow Formation of middle and late Miocene age; similar lithologically and in stratigraphic position to, and therefore presumably correlative with, Kinnick Formation of middle and possibly early Miocene age of Monolith and Cache Peak area. and to Gem Hill Formation of Oligocene (?) to middle Miocene(?) age; Pickhandle Formation therefore most likely of Oligocene(?) to early or middle Miocene age.

OPAL MOUNTAIN VOLCANIC FORMATION

Volcanic rocks of rhyolite and quartz latite composition occurring as intrusive plugs and extrusive flow breccias in pyroclastic rocks of Pickhandle Formation in area of Opal Mountain and upper Black Canyon and in Gravel Hills (pl. 1) ; mapped and described separately as Opal Mountain Volcanic Formation; named for Opal Mountain; type locality in vicinity of Opal Mountain and forks of Black Canyon to northwest (Dibblee, 1967 ; fig. 53, pl. 1). Officially adopted for use in this report.

Formation composed of following three facies: rhyolitic felsite, rhyolitic breccia, and perlite (figs. 53, $56,57)$.

Rhyolitic felsite pink to tan, massive to flow laminated, aphanitic to slightly porphyritic; contains scattered small phenocrysts of plagioclase (oligoclaseandesine) in microcrystalline groundmass of orthoclase, quartz, and plagioclase in order of decreasing abundance; forms intrusive plugs or necks commonly with concentric flow laminae and fracture parting parallel to outer walls of each plug. In Black Canyon, several very small plugs composed of buff pumiceous felsite.

Rhyolitic breccia mostly dark-brownish red, locally brown to greenish brown; composed of angular fragments of massive to flow-laminated rhyolitic felsite embedded in felsite matrix; occurs as outer zones at margins of some intrusive plugs of rhyolitic felsite, but mostly as large volcanic piles and flow breccias wedging out into tuff.

Perlite, steel gray, glassy, massive, with numerous curved fractures; forms chilled zones as thick as 30 feet around margins of some plugs of rhyolitic felsite and at base of some rhyolitic flow breccias; perlite commonly grades into both these facies through transitional zones of dark-reddish-brown subvitreous felsite containing spherulites and nodules filled with silica (chalcedony and opal). Perlite most prevalent in Opal Mountain-Black Canyon area (fig. 53).

Volcanic rocks emplaced during time of deposition of Pickhandle Formation and therefore of same age.

\section{BARSTOW FORMATION}

A terrestrial sedimentary sequence of Miocene age: exposed in Mud Hills and Gravel Hills. Exposures in Mud Hills named Barstow Formation by Merriam (1915, p. 252-254; 1919, p. 441-448); mapped and described in detail by writer (Dibblee, 1967). Type section designated as south-dipping sequence in eastern Mud Hills just west of Solomon Canyon, in sec. 20 and $\mathrm{N} 1 / 2$ sec. 29, T. $11 \mathrm{~N}$., R. $1 \mathrm{~W}$. (approximately along section line $B-B^{\prime}$, fig. 55) measured and described in detail by Durrell (1953, section $A-A^{\prime}$, pl. 4, fig. 12).

In Mud Hills (figs. 54 and 55), formation ranges from 2,000 to 3,000 feet thick ; folded into major syncline generally known as Barstow syncline; unconformably overlies Pickhandle Formation in places with angular discordance as much as $25^{\circ}$; eroded top unconformably overlain by generally flat-lying locally granitic older Quaternary alluvium.

Basal part of formation is conglomerate on north flank of Barstow syncline, conglomerate as thick as 250 feet, overlain by algal limestone; on south flank conglomerate greenish gray to red; as thick as 900 feet, base unexposed; includes some interbedded sandstone and shale.

Basal conglomerate overlain by about 1,700 feet of interbedded clay shale and sandstone.

Sequence includes occasional beds few inches or few feet thick of hard cream-white impure limestone or dolomite and white fine- to medium-grained rhyolitic tuff; one bed at top of sequence as thick as 5 feet and forms prominent white marker. Sequence changes markedly along strike; on south flank of syncline entire sequence grades laterally westward into poorly 
bedded brownish-gray conglomerate and some fanglomerate in southwestern Mud Hills.

Sequence west of Solomon Canyon (type section) generalized as follows in descending order:

Type section of Barstow Formation, west of Solomon Cunyon (sec. 20, $N \mathrm{H}_{2}$ sec. 29, T. 11 N., R. 1.W., fig. 55)

Older alluvium of Quaternary age.

Unconformity.

Barstow Formation:

Conglomerate and sandstone, light-gray-brown, contains cobbles and pebbles mostly of granitic rocks, $\begin{gathered}\text { Thick- } \\ \text { ness }\end{gathered}$ some of quartzite, hornfels, and andesite; lower (feet) part mostly sandstone...................... 448

Limestone, gray, locally cherty $\ldots . . \ldots 28$

Sandstone, light-gray, bedded........ 50

Tuff, white .............

Clay shale and sandstone, interbedded, yellowish- to light-greenish-gray; clay shale predominating; includes occasional thin strata of hard nodular impure limestone and soft brown bentonite...... 1, 314

Tuff, white ...............................

Sandstone, light-gray, contains scattered lapilli of

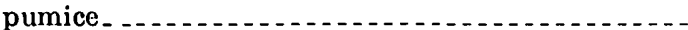

Algal limestone, dark-gray, irregularly bedded; composed mainly of calcareous algae or tufa? ........

Conglomerate, greenish-gray; clasts mostly of granitic rocks, few of pegmatite, aplite, and andesite

Total exposed thickness, Barstow Formation_. _ 2, 155 Unconformity.

Pickhandle Formation.

In Gravel Hills (figs. 53, 56, 57, and pl. 1), Barstow Formation overlies Pickhandle Formation conformably in lower Black Canyon, unconformably elsewhere; to north it laps onto pre-Tertiary plutonic rocks. Formation as thick as 4,500 feet in southwestern Gravel Hills adjacent to Harper Valley, but thins rapidly northward.

In lower Black Canyon 3 miles above mouth and in core of anticline, to west, lowest 500 feet of Barstow Formation composed of thin-bedded light-gray shale that grades upward through buff sandstone into coarse fanglomerate that makes up bulk of Barstow Formation of Gravel Hills.

Fanglomerate composed of two distinct facies: one of granitic detritus, the other of volcanic detritus. In southeastern part of area, granitic fanglomerate intertongues northeastward into volcanic fanglomerate (fig. 57); in northwestern part, volcanic fanglomerate occurs as lenticular mass within granitic fanglomerate (fig. 56). Both facies composed of unsorted subrounded to angular fragments as much as 8 feet across in weakly consolidated light-gray coarse sandy matrix.
Fanglomerate of granitic detritus light gray; most fragments of granitic rocks presumably quartz monzonite; other fragments of aplite, pegmatite, quartz diorite, hornblende diorite, and gray to tan porphyritic and felsitic igneous rocks of pre-Tertiary age. Fanglomerate of volcanic detritus light-pinkish gray; most fragments of reddish to pinkish brown massive to laminated rhyolitic and felsitic volcanic rocks of Tertiary age; other fragments of Tertiary brown andesite porphyry, basalt, volcanic chert, jasper, and opal, rarely of pre-Tertiary granitic rocks.

In Mud Hills, uppermost part of Barstow Formation (part above marker tuff bed) yielded one of largest vertebrate faunas in North America. Fauna first studied and described as Barstow fauna by Merriam $(1919$, p. $441-448)$ who determined it to be late Miocene in age, definitely older than Ricardo (Clarendonian) fauna. Strata containing Barstow fauna regarded as type for Barstovian Stage, upper Miocene (Wood and others, 1941, p. 12; Savage and others, 1954, p. 48-49).

Fossil material collected by members of U.S. Geological Survey from 11 localities in Barstow Formation of western Mud Hills (fig. 54) under study. Nine localities from upper part; two from middle part; lower part unfossiliferous. Preliminary studies indicate upper part late Miocene (Barstovian); middle part middle Miocene (Hemingfordian) in age (Lewis, 1964).

In eastern Gravel Hills just northwest of lower Black Canyon, four localities (two shown in fig. 57) yielded remains of several mammalian species of late Miocene (Barstovian) age.

Sakel palm, similar to existing palms in warm parts of northern Mexico (Savage and others, 1954, p. 48) only kind of plant remains found in Barstow Formation.

Fresh-water diatom remains found by $\mathbf{K}$. E. Lohman in lacustrine clay shale within 1,700-foot interval between basal conglomerate and marker tuff bed on south flank of Barstow syncline in south central Mud Hills, and in clay of 100 -foot interval starting at 20 feet stratigraphically above tuff bed northwest of lower Black Canyon near vertebrate fossil locality shown on figure 57. Preliminary study indicates assemblage from Black Canyon locality to be composed of 35 species and similar to assemblage from Virgin Valley Beds of Merriam (1907), Barstovian age, of Humboldt County, Nevada (K. E. Lohman, written commun., 1955). 


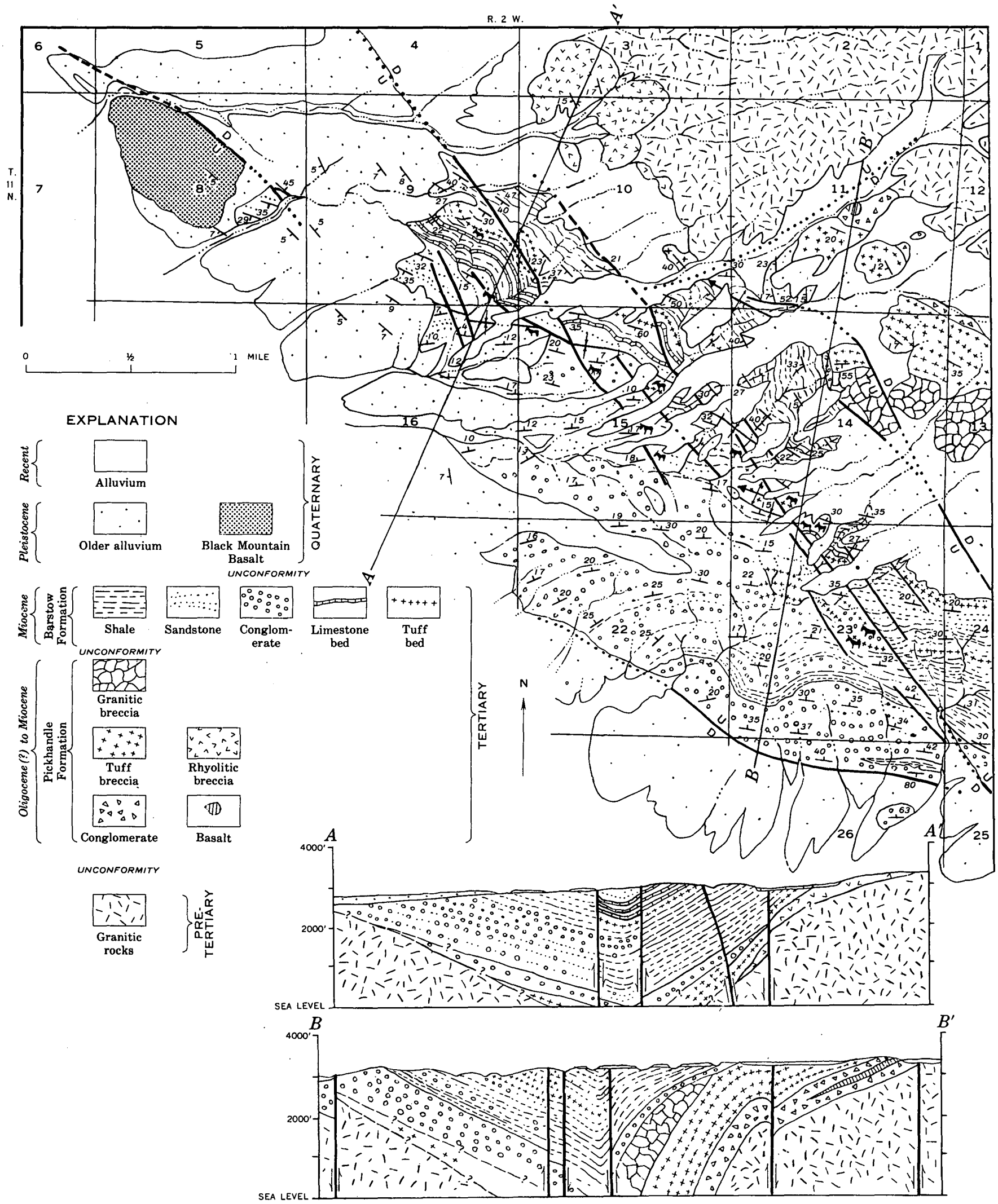

FraURE 54.-Geologic map and sections of western Mud Hills. 


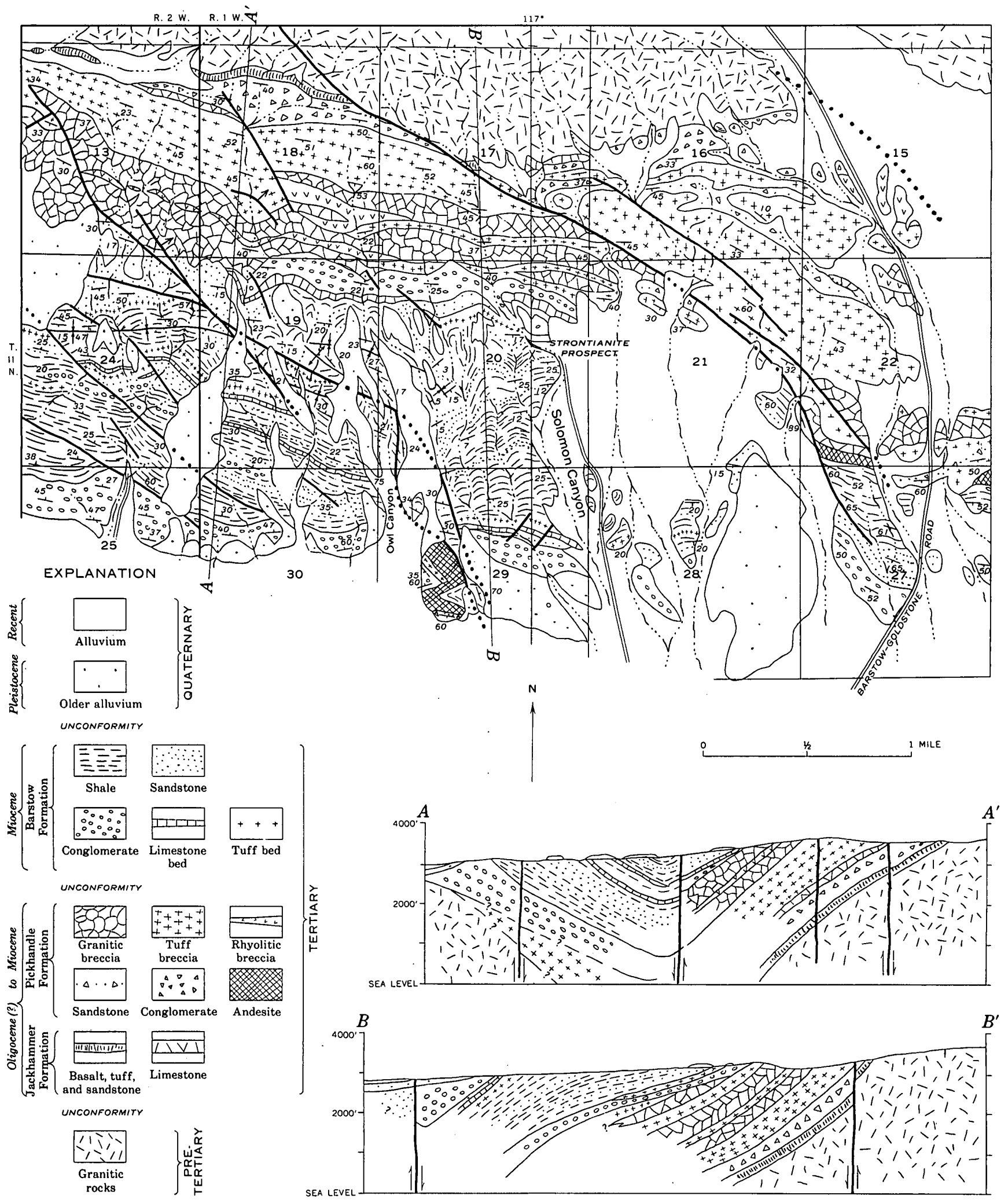

Figure 55.-Geologic map and sections of eastem Mud Hills. 


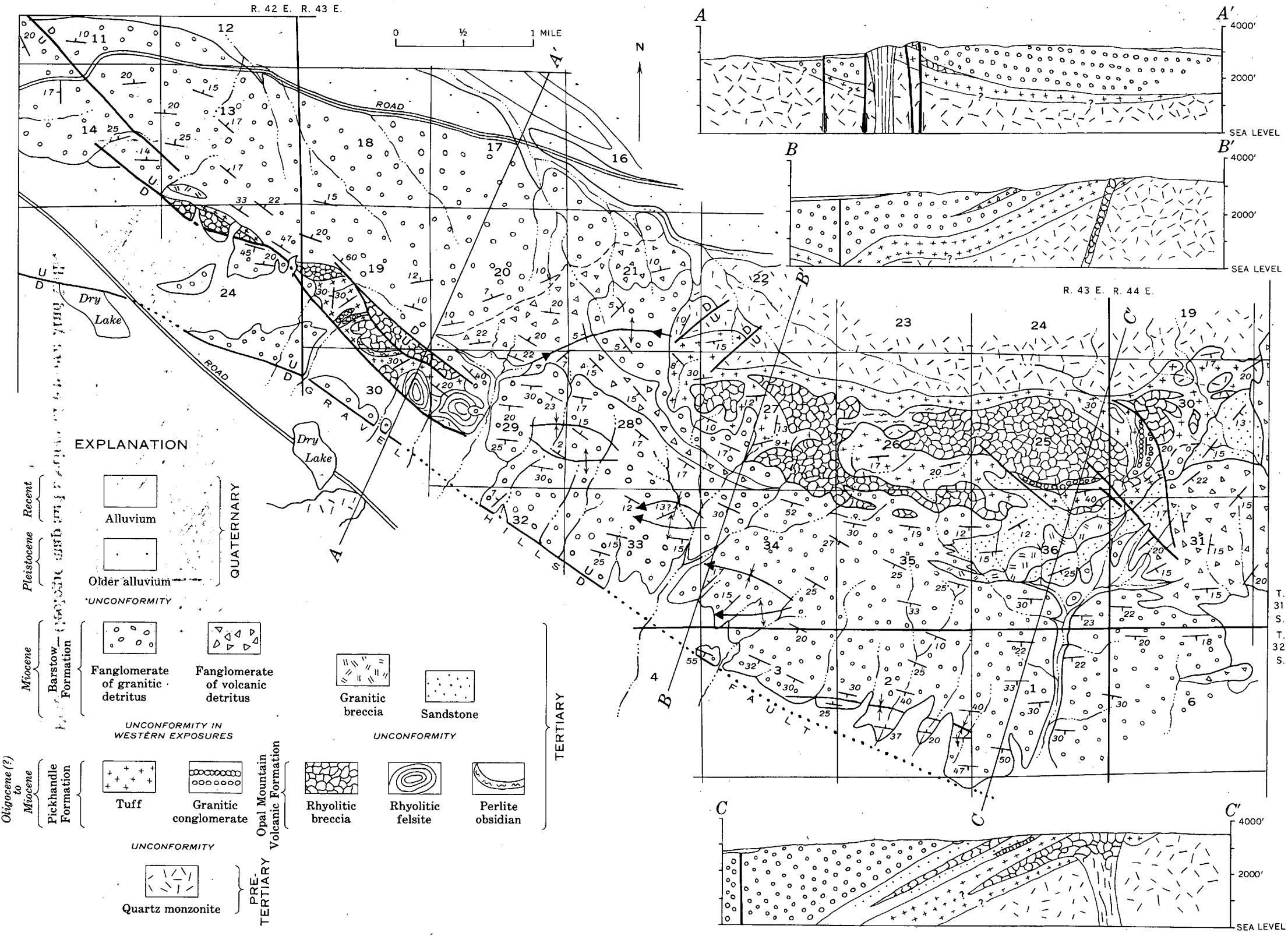




\section{LANE MOUNTAIN ANDESITE}

Andesite extruded onto eroded surface of quartz monzonite covers about 2 square miles to form slightly domed nearly flat topped butte about 7 miles eastsoutheast of Opal Mountain. Several other local extrusions form similar buttes to north and east beyond border of mapped area. Formation named by McCulloh (1952; Dibblee, 1967) for Lane Mountain, the type locality, in Lane Mountain quadrangle (15 miles east-southeast of Opal Mountain). Officially adopted for use in this report.

Rock gray to brown, massive, porphyritic; composed of phenocrysts making up 25-50 percent of rock in aphanitic to vitreous groundmass. Most phenocrysts of plagioclase (andesine), others of basaltic hornblende and biotite; groundmass mainly glass, partly devitrified, having index of refraction of 1.50 .

Andesite composed of one or more flows totaling about 480 feet thick; lowest part somewhat brecciated; slightly domed shape of butte suggests flow probably thickest at center and possibly underlain by andesite plug.

Field relations in Calico Mountains beyond east border of mapped area indicate andesite lies unconformably on Barstow Formation and is therefore younger, presumably of Pliocene age ( $\mathrm{McCulloh}$, 1952).

\section{ROCK UNITS OF NORTHERN AREAS}

\section{THFACHAPI VALIEY AND CACHE PEAK AREAS}

WITNET FORMATION

A fluviatile sedimentary sequence of probable early Tertiary age unconformable on Mesozoic granitic rocks in Cache Creek and Oil Canyon northeast of Monolith. Named by Buwalda (1954, p. 134) and Buwalda and Lewis $(1955$, p. 147) after Witnet Ridge, north of Oil Canyon; type section in Oil Canyon within a mile above its juncture with Cache Creek. Formation also exposed in upper Jawbone Canyon, and in hills 3-6 miles southwest of Monolith (pl. 1).

In Cache and Oil Canyons Witnet Formation as thick as 4,000 feet; composed mainly of buff locally pebbly arkosic sandstone, interbedded dark-reddishgray micaceous siltstone and some conglomerate with pebbles and cobbles of quartzite, porphyry, and granitic rocks. Gray granitic-cobble conglomerate as much as 50 feet thick at base locally. Formation overlapped northeastward by Kinnick Formation (figs. 58, 59, and $60)$.

In upper Jawbone Canyon, formation about 1,400 feet thick; lower 600 feet composed of gray to red massive granitic conglomerate, upper 800 feet of buff sandstone and interbedded red siltstone as in Oil Canyon (fig. 59).

In hills southwest of Monolith, about 2,500 feet of Witnet Formation exposed resting on quartz monzonite; top eroded (pl. 1); composed mainly of buff arkosic sandstone; contains lenses of brown cobble conglomerate, mostly in lowest 600 feet, and minor interbedded siltstone layers in upper part. Conglomerate composed of cobbles of granitic rocks, aplite, quartzite, and metaporphyry.

Formation unfossiliferous, but older than unconformably overlying Kinnick Formation of middle and perhaps early Miocene age; formation therefore of early Tertiary age; lithologically similar to, and presumably correlative with, Goler Formation (Paleocene and Eocene) in El Paso Mountains.

\section{KINNICK FORMATION}

A dominantly pyroclastic formation of Miocene age exposed in hills northeast of Tehachapi Valley (pl. 1). Named by Buwalda (1954, p. 134-135; Buwalda and Lewis, 1955, p. 147) after Kinnick Ridge east of Sand Creek; type section from base at unconformity at confluence of Cache, Oil, and Sand Creeks N. $20^{\circ}$ W. for about half a mile. Present also in lower Jawbone Canyon.

In hills northeast of Tehachapi Valley (figs. 58, 59, 60) Kinnick Formation as much as 2,100 feet thick; composed of lenticular bedded white to greenish-white quartz-bearing tuff, tuff breccia, tuffaceous sandstone and tuffaceous shale, and several flows (or perhaps sills) of basalt. Intertongues northeastward into andesite of Cache Peak.

On Southeast side of Lone Tree Canyon (fig. 59), formation composed of basal layer of white bentonite overlain by about 300 feet of tuffaceous rocks, followed by several lenses of basalt, then by lenticular mass as thick as 1,000 feet of tan felsite breccia or rubble exposed mostly in sec. 8, T. 32 S., R. 35 E.; formation wedges out, or is overlapped, northeastward.

In upper Jawbone Canyon (figs. 59, 60), formation as thick as 3,000 feet; lowest 600 feet is white tuff and tuff breccia; remainder composed of greenish-brown andesite conglomerate and breccia that intertongues westward into andesite of Cache Peak.

In lower Jawbone Canyon (fig. 61), formation as much as 3,000 feet thick; composed of lenticular masses of tuff, tuff breccia, arkosic sandstone, pink granitic breccia, gray quartz diorite breccia, basalt flows, and basal lens of conglomerate.

Vertebrate fossils (Phillips Ranch fauna) from upper part of Kinnick Formation in Sand Canyon (fig. 58) suggest middle Miocene (Hemingfordian) 

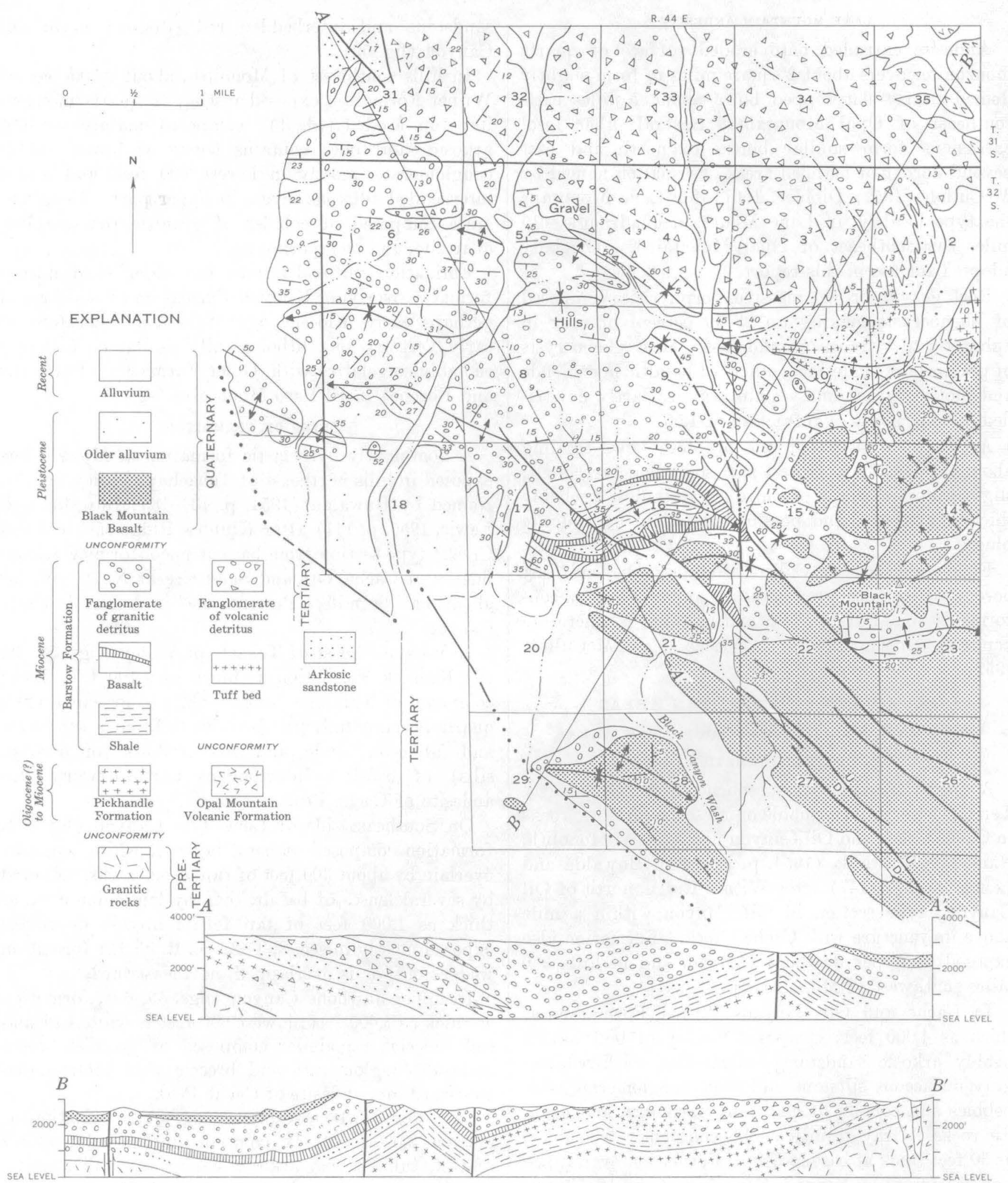

FIgURE 57.-Geologic map and sections of southeastern Gravel Hills and lower Black Canyon. 
age (Buwalda, 1916, p. 77, 79, 83, 84; Buwalda and Lewis, 1955, p. 150-152). Tehachapi flora, including 69 trees and shrubs, found near Phillips Ranch fauna and from same horizon, dated as early middle Miocene (Savage and others, 1954, p. 45).

Kinnick Formation similar to, and tentatively correlated with, Gem Hill Formation, Neenach Volcanic Formation, and Pickhandle Formation. Considered to be of middle and perhaps early Miocene or Oligocene age.

\section{RHYOLITIC FELSITE}

In eastern Tehachapi Mountains, on both sides of Garlock fault, dikes, pods, and plugs of rhyolitic felsite intrusive into granitic rocks (pl. 1, figs. 13, 62); rock probably same as, or related to, Bobtail Quartz Latite Member of Gem Hill Formation.

In southern Sierra Nevada, between Lone Tree and Jawbone Canyons, rhyolitic felsite also forms many dikes, pods, and volcanic plugs intrusive through granitic rocks into Witnet and Kinnick Formations (fig. 61). Rhyolitic breccias of Kinnick Formation, such as on Cross Mountain, presumably extrusive masses from adjacent plugs.

Felsite light tan to locally pinkish white, massive to flow laminated, aphanitic; some larger masses porphyritic with scattered to abundant phenocrysts of feldspar, quartz, and biotite.

Rock probably same age as Kinnick Formation with which it is associated; similar to and probably correlative with Bobtail Quartz Latite Member of Gem Hill Formation.

\section{BOPESTA FORMATION}

A terrestrial sedimentary sequence of late Miocene age overlying Kinnick Formation in mountains near Cache Peak eastward from Sand Creek (pl. 1, figs. 58, 59). Named by Buwalda (1954, p. 135) and Buwalda and Lewis (1955, p. 148) after Bopesta Ridge southwest of Cache Peak; type section near confluence of Cache Creek and its east fork (which heads on south side of Cache Peak).

Bopesta Formation as much as 2,800 feet thick: composed mostly of buff to light-gray arkosic sandstone, commonly conglomeratic, with quartzite pebbles and cobbles and some interbedded siltstone. In southernmost exposures, lower part of formation composed of olive-green siltstone, platy semisiliceous shale, interbedded sandstone, flows of basalt, and local basal arkosic conglomerate as much as 200 feet thick.

In northern exposures, Bopesta formation intertongues with and is overlain by andesite of Cache Peak area.
Basalt in Kinnick and Bopesta Formations black, massive, nonvesicular, fine grained, ophitic; composed of about 70 percent plagioclase (calcic andesine or labradorite), 30 percent ferromagnesian minerals (mostly augite, rarely olivine), and less than 1 percent iron oxides (mostly magnetite).

Vertebrate fossils (Cache Peak fauna) from locality on east fork of Cache Creek (fig. 58) now regarded as late Miocene (Barstovian) in age (Savage and others. 1954, p. 45; Buwalda and Lewis, 1955, p. 148).

NOTE: Siltstone, shale, and sandstone beds that form lower part of Bopesta Formation as shown on figures 58 and 59 between lower Sand Creek and head of Lone Tree Canyon, are erroneously included in Kinnick Formation on plate 1. These beds, formerly included in Kinnick Formation, are now included in Bopesta Formation because they are nonpyroclastic and, together with basal conglomerate in Lone Tree Canyon are locally unconformable on underlying pyroclastic rocks of Kinnick Formation.

\section{ANDESITE}

Andesite exposed over wide area in Cache Peak area (pl. 1) and extends northwestward some 12 miles beyond border of mapped area. Eastern offshoots or feeders and dikes intrude granitic bedrock, Witnet Formation, and into Kinnick and Bopesta Formations east of Cache Peak; main volcanic mass in part intrusive and in part a sequence of thick andesitic flows totaling perhaps 3,000 feet; flows wedge out southeastward into Kinnick and Bopesta Formations; highest flow overlies Bopesta Formation (figs. 58, 59, 60).

Andesite present also as remnants of small intrusion and as flows on eroded surface of Kinnick Formation and on rhyolitic felsite on north flank of Chuckawalla Mountain (fig. 61) ; porphyritic, phenocrysts making up 40-50 percent by volume; most phenocrysts rectangular, or white plagioclase (andesine); but some prismatic, of black oxyhornblende; groundmass aphanitic to very fine grained, composed mainly of plagioclase, and specks of hematite and magnetite.

Andesite same age as Kinnick and Bopesta Formations and in part younger, or early (?), middle, and late Miocene, and possibly early Pliocene, as indicated by intertonguing relationships; in part possibly equivalent to, but mostly younger than, felsite of Jawbone Canyon area.

\section{HORNED TOAD HILLS AREA HORNED TOAD FORMATION}

A terrestrial sedimentary sequence of Pliocene age overlying Mesozoic quartz monzonite and unconformably overlain by Pleistocene alluvial sediments in foot- 


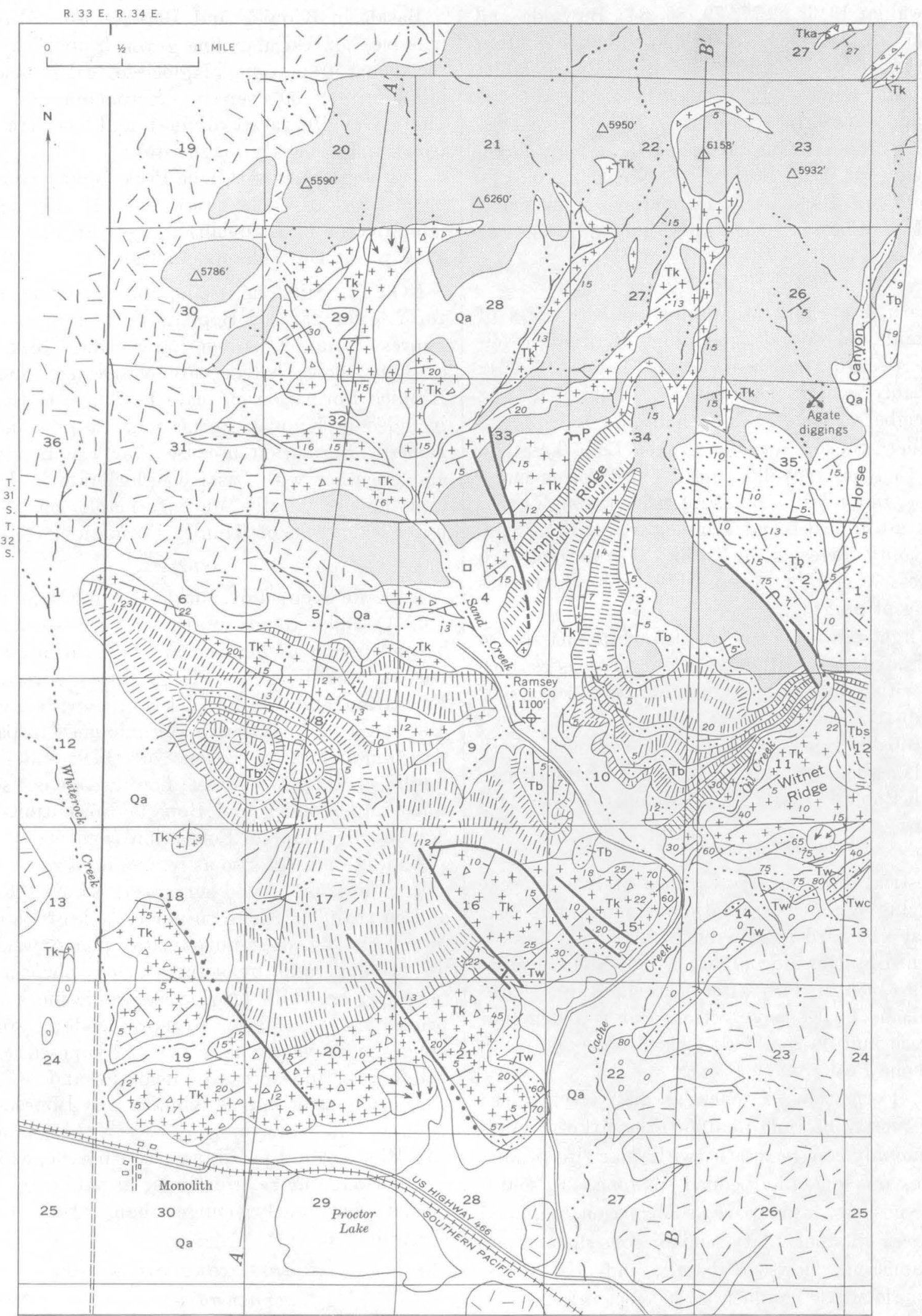

Figure 58.-Cenozoic geology of Monolith-Sand Creek area, southern Sierra Nevada. Explanation is shown on figure 59 . 


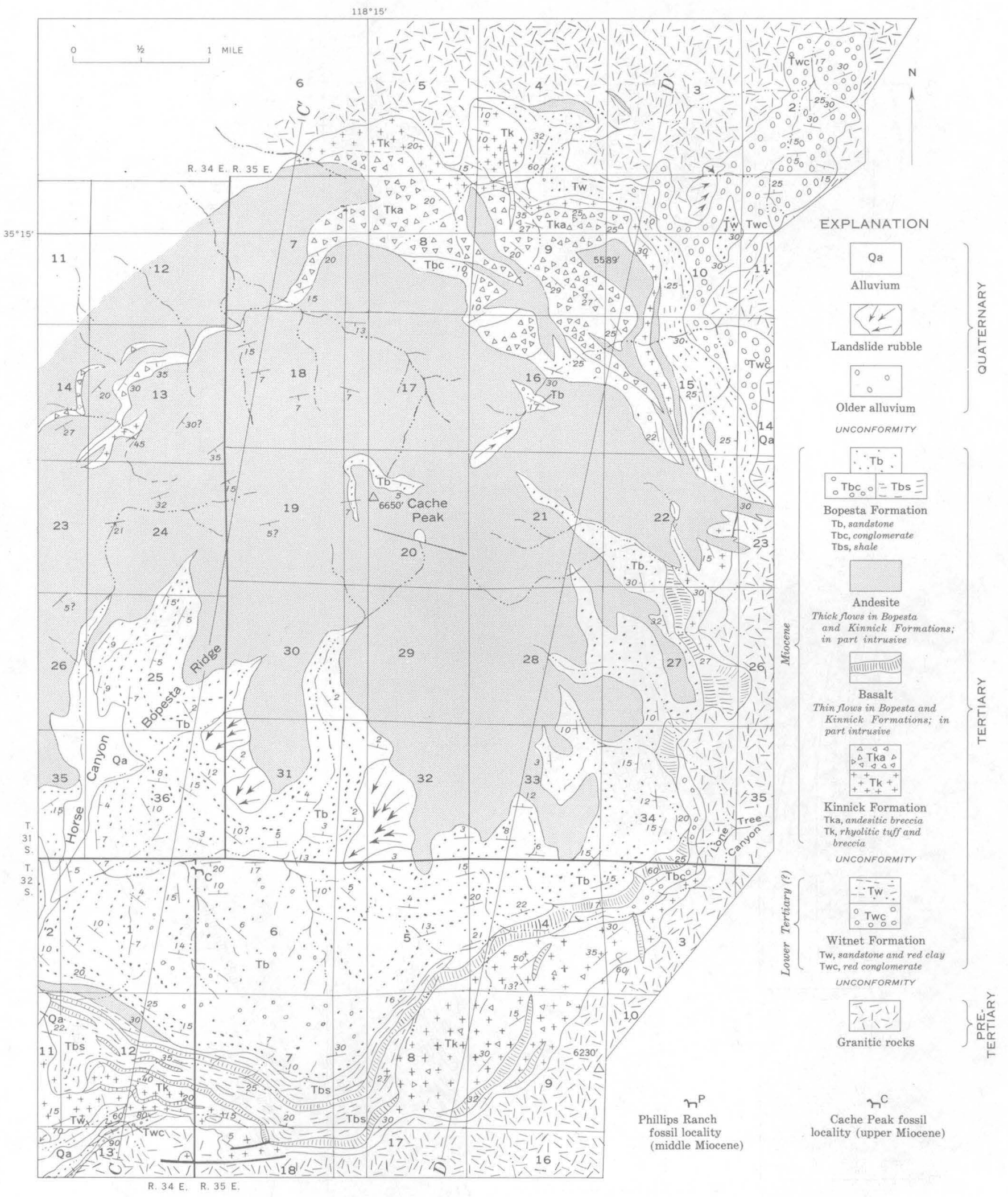

Figure 59.-Cenozoic geology of Cache Peak area, southern Sierra Nevada. 

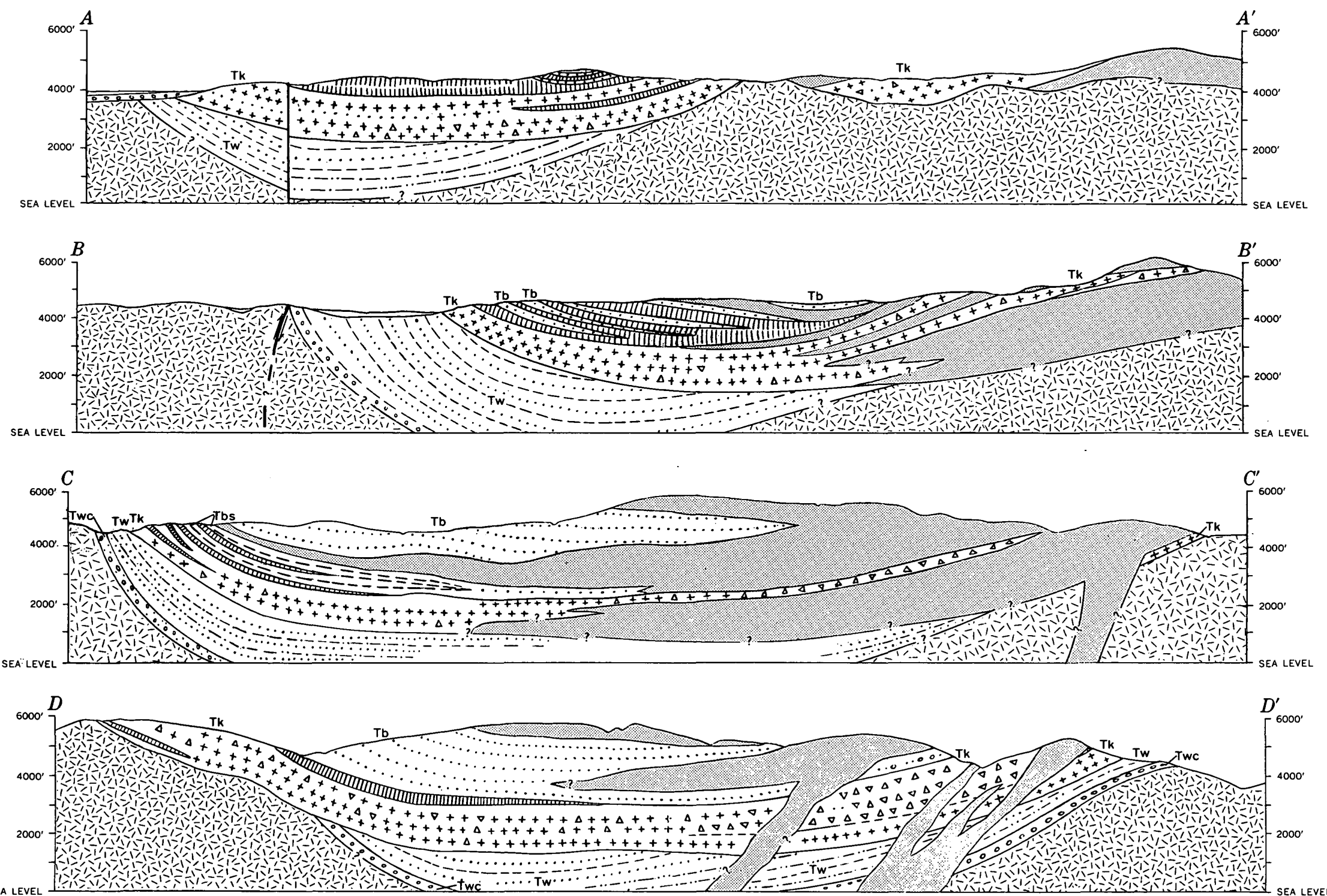

Figure 60.--Sections of Monolith and Cache Peak areas, southern Sierra Nevada. Locations of sections are shown on figures 58 and 59. 


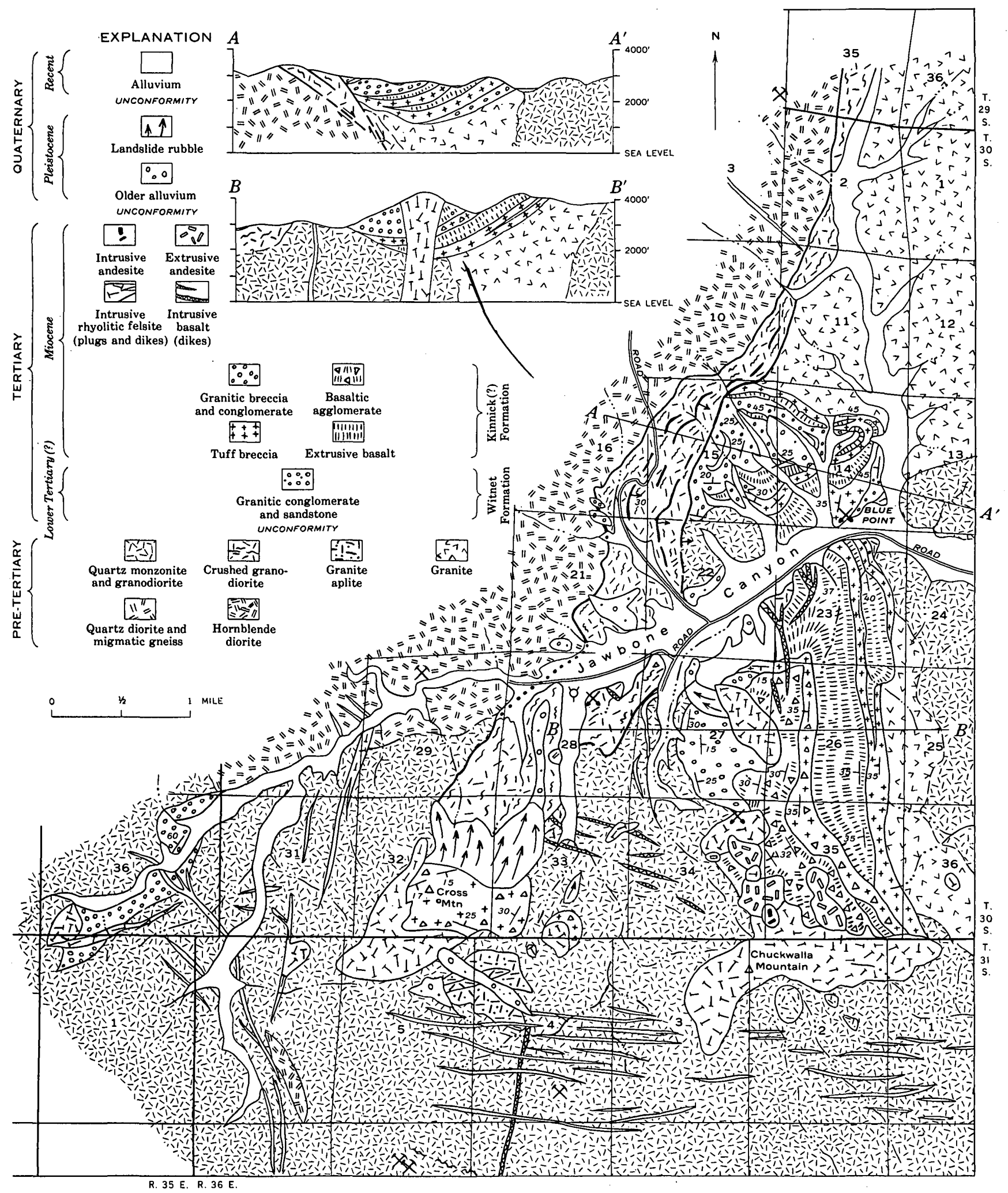

Fraure 61.-Geologic map and sections of Jawbone Canyon area, southern Sierra Nevada. 
hills northwest of Mojave; named after Horned Toad Hills southwest of Warren railway camp (Dibblee, 1958c, p. 143, 1959b). Type section in Horned Toad Hills, from base of formation about 7,000 feet S. $70^{\circ}$ W. of Warren railway camp south-southeast 1 mile to top of formation (fig. 62).

Formation about 1,050 feet in average exposed thickness and composed of three parts or members (fig. 62) ; sequence and lithology of members shown below; thickness given are at type section, but along strike maximum thickness of upper member 90 feet, of middle member 130 feet, and of lower member 800 feet.

Horned Toad Formation, Horned Toad Hills (fig. 62)

Sand and silt of older alluvium, Pleistocene.

Unconformity.

Horned Toad Formation:

Upper member: greenish-gray argillaceous gypsifer-

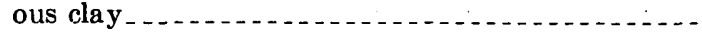

Middle member: limestone, shale, and sandstone, interbedded. Limestone white, soft, marly; forms strata as thick as $2 \mathrm{ft}$. Shale greenish-gray, soft, sandy; forms strata as thick as $5 \mathrm{ft}$. Sandstone green, massive to bedded; composed of ill-sorted fine to coarse grains of quartz and feldspar in cla yey matrix; forms strata as thick as $5 \mathrm{ft}$; in places contains thin layers of gray volcanic ash........

Lower member: mostly buff friable fine- to mediumgrained arkosic sandstone. Includes interbedded light-reddish gray sandy clay and siltstone in upper and middle parts; pebbly sandstone and conglomerate in lower part contain pebbles and cobbles of granitic rocks and few of bleached platy felsite; locally at base contains lens as thick as $70 \mathrm{ft}$ of conglomerate of granitic cobbles and boulders....... Unconformity.

Quartz monzonite intruded by rhyolitic to andesitic felsite.

Vertebrate fossils (Warren fauna) collected by paleontologists from University of California, Berkeley. from two localities within 2 miles southwest of Warren railway station, presumably from middle member of Horned Toad Formation, most closely allied to California faunas of middle Pliocene (late Hemphillian) age (R. H. Tedford, D. E. Savage, University of California, Berkeley, written commun. Nov. 23, 1960).

\section{EL PASO MOUNTAINS AREA} GOLER FORMATION

A fluviatile clastic sedimentary formation of early Tertiary age unconformable on pre-Tertiary plutonic and metamorphic rocks and unconformably overlain by Ricardo Formation in El Paso Mountains (pl. 1, figs. 64-66) ; mapped, described, and named after Goler Gulch (Dibblee, 1952, p. 19, 22-25, pl. 1) ; referred to Rosamond Series (of former usage) by Hulin (1925, p. 42, pl. 1). Goler Formation officially adopted for use in this report.

Type section from base of formation in Goler Gulch in $\mathrm{NE} 1 / 4$ sec. 34, T. 28 S., R. 39 E., or 2 miles southsoutheast of Holland Camp, north up Goler Gulch, over low pass, and down canyon draining due north nearly to gravel quarries in sec. 32 , T. 27 S., R. 39 E. (fig. 65).

Goler Formation as much as 6,500 feet thick; thins northeastward. Basal conglomerate as much as 500 feet thick between Goler Gulch and Iron Canyon; composed of smoothly rounded cobbles of quartzite, chert, hornfels, porphyries, and granitic rocks in sandy matrix; remainder of formation composed of buff to locally red arkosic sandstone and some interbedded green to red siltstone; grades laterally eastward into cobble conglomerate similar to basal conglomerate.

Plant remains reported from Goler Formation considered to be Eocene in age (Dibblee, 1952, p. 25). Primitive vertebrate fossils (Laudate fauna), reported from two localities near top of Goler Formation north of Goler Gulch, considered to be of Paleocene age by McKenna (1960). Goler Formation therefore now considered to be Paleocene and Eocene in age.

Dacite present as small exposure south of mouth of Jawbone Canyon and just east of Sierra Nevada fault (fig. 63). Occurs as flow breccia and some irregular lenses of white tuff breccia; at least one plug with flow laminae concentric around its central core. Rock of plug pale pink gray, flow laminated, felsitic; contains scattered small phenocrysts of plagioclase, quartz. and biotite; breccia similar but darker, massive.

Dacite overlain unconformably by coarse conglomerate of Ricardo Formation, therefore older; either correlative with tuff (member 2) of Ricardo Formation in Last Chance Canyon, or possibly with Kinnick Formation to west in Jawbone Canyon.

\section{RICARDO FORMATION}

A sequence of terrestrial sedimentary and volcanic rocks unconformable on Goler Formation and preTertiary rocks, and overlain by Black Mountain Basalt (Pleistocene?) in El Paso Mountains (pl. 1): named by Merriam (1914, p. 276, 278; 1917, p. 430-443; 1919 , p. $447-448)$; described and mapped by writer (Dibblee, 1952, p. 25-30, pl. 1) ; type section between Redrock and Last Chance Canyons.

Formation composed essentially of detrital sedimentary rocks ranging from coarse fanglomerate to fine clay and chemically deposited siliceous and calcareous sediments; includes tuffaceous rocks and flows of basalt and andesite. Basalt similar to that of Kinnick 


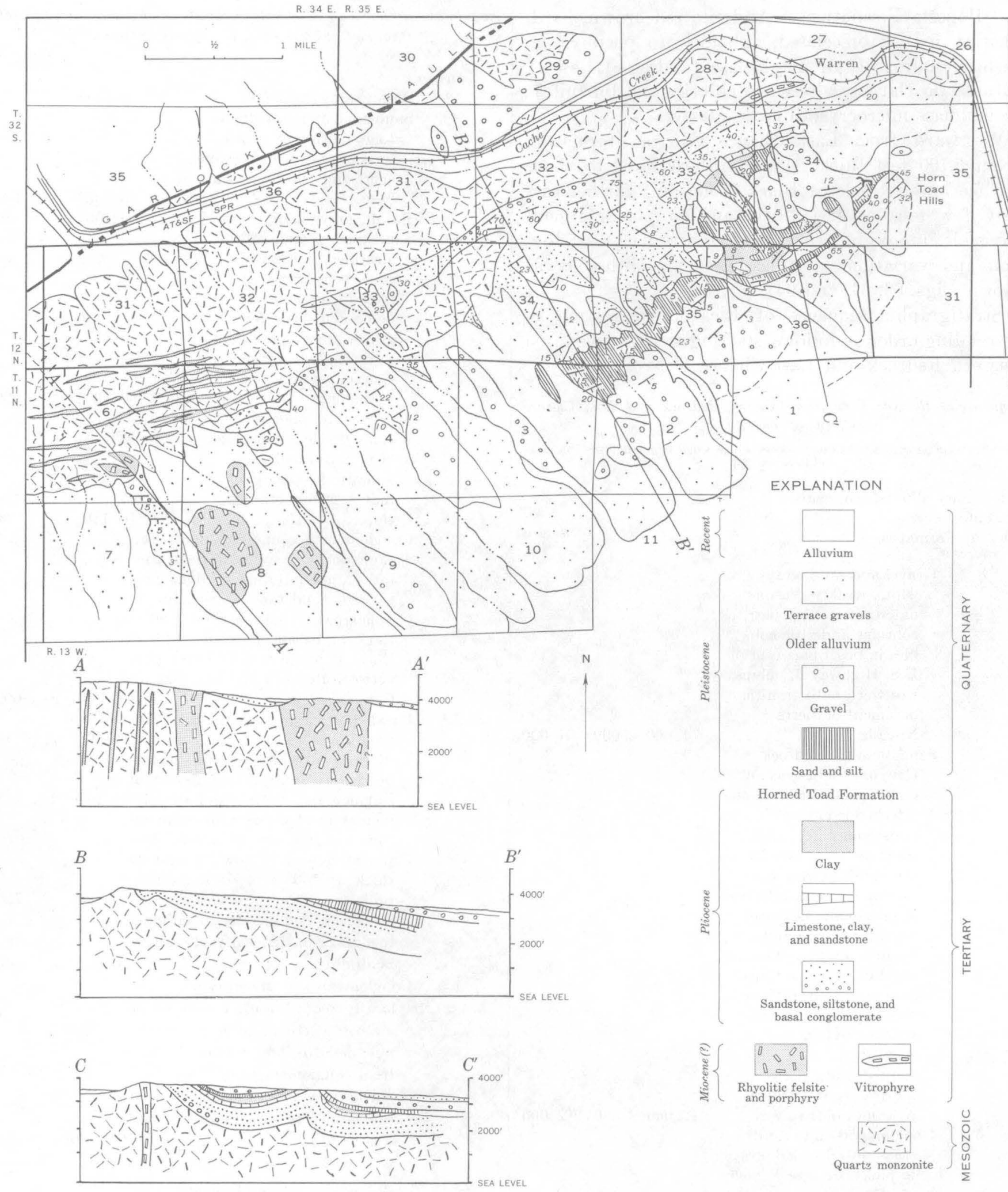

Figure 62.-Geologic map and sections of Horned Toad Hills area. 
and Bopesta Formations. Andesite red brown, hard, massive, locally brecciated, aphanitic to porphyritic, phenocrysts mainly of plagioclase (andesine), few of hornblende (largely altered to chlorite and limonite); groundmass microcrystalline to glassy.

Westward from Last Chance Canyon, formation about 5,700 feet thick; thins northeastward to about 400 feet on east side of Black Mountain; farther east only few tens of feet thick, and in places absent. Divisible into eight lithologic members with distribution and variations in thicknesses and lithology as shown (figs. 63, 64, and 66).

Stratigraphic sequence of Ricardo Formation in descending order as follows, starting from type section between Redrock and Last Chance Canyons:

\section{Sequence of Ricardo Formation between Redrock and Last Chance Canyons (figs. 63, 64) \\ [Two figures in parentheses indicate thickness range, single figure indicates thickness} at type section]

Quaternary alluvial sediments.

Unconformity.

Ricardo Formation:

Member

8. Gravel and sand, gray-

white, weakly consoli-

dated; of granitic detritus;

contains andesitic cob-

bles in basal part east of

U.S. Highway 6 ; onlaps

westward onto granitic

basement of Sierra

Nevada. . . . . . . . . . . .

7. Sandstone (in Redrock

Canyon), light-gray; of

granitic detritus; contains

interbedded greenish

micaceous clay; grades

nor theastward into light-

gray nodular clay con-

taining frequent interbeds

of gray-white lacustrine

carbonate rocks and

opaline chert; southwest-

ward in Jawbone Canyon

area grades through bed-

ded conglomerate into

coarse fanglomerate of

granitic and some volcanic detritus derived apparently from Sierra

Nevada uplift to west....

$(1,000-2,000) \quad 1,000$

Thickness (feet)

Conglomerate and sandstone, interbedded, gray to pink; composed chiefly of volcanic and minor granitic detritus; northeastward from Ricardo becomes pink volcanic conglomerate and thins out ...................

$(0-600) \quad 400$
Sequence of

of Ricardo Formation between Redrock and Last Chance Canyons (figs. 63, 64)-Continued

Member

5.1 Basalt, amygdaloidal ..... (0-100)

Thickness
(feet)

Sandstone and clay, lightto greenish-gray; hard beds of gray-white opaline chert and limestone near

base..................

4. 1 Sandstone, prominently stratified, light-gray; some beds brick red; includes some interbedded green clays; few of gray-white impure limestone; in Last Chance

Canyon, six beds of white volcanic ash 1-9 ft thick.

$(0-600)$

Tuff breccia, pinkish-white, thick-bedded; composed

of pumice lapilli and andesite fragments in matrix of fine-grained tuff ....................

3. Conglomerate, pink-gray; of volcanic detritus; well stratified; contains much interbedded light-gray to red sandstone, especially in upper part; contains lens $0-20 \mathrm{ft}$ thick of basalt and lens $0-30 \mathrm{ft}$ thick of white tuff in lower part between Redrock and Last Chance

Canyon......... (0-800)

2.2 Basalt; occurs as several discontinuous lenses at top............... (0-30)

Tuff breccia, white to pink, thickbedded to massive; composed of fragments of pumice and andesite in matrix of massive fine-grained tuff; includes one to several lenticular flows and flow breccias as thick as $100 \mathrm{ft}$ of dark reddishbrown andesite.............. (0-700)

Tuff, white, well-bedded, mediumto fine-grained; locally altered to bentonite $(0-50)$

1. Conglomerate, greenish-gray to locally reddish-buff; composed of granitic detritus, some metamorphic detritus, and reworked clasts from conglomerates of Goler Formation; includes some interbedded sandstone; buttresses out southwestward . . . . . . . . . . . . (0-400)

Total thickness of Ricardo Formation at type section.......

Angular unconformity.

Goler Formation and pre-Tertiary rocks.
1 Thins northeastward.

2 Onlaps and pinches out southwestward. 


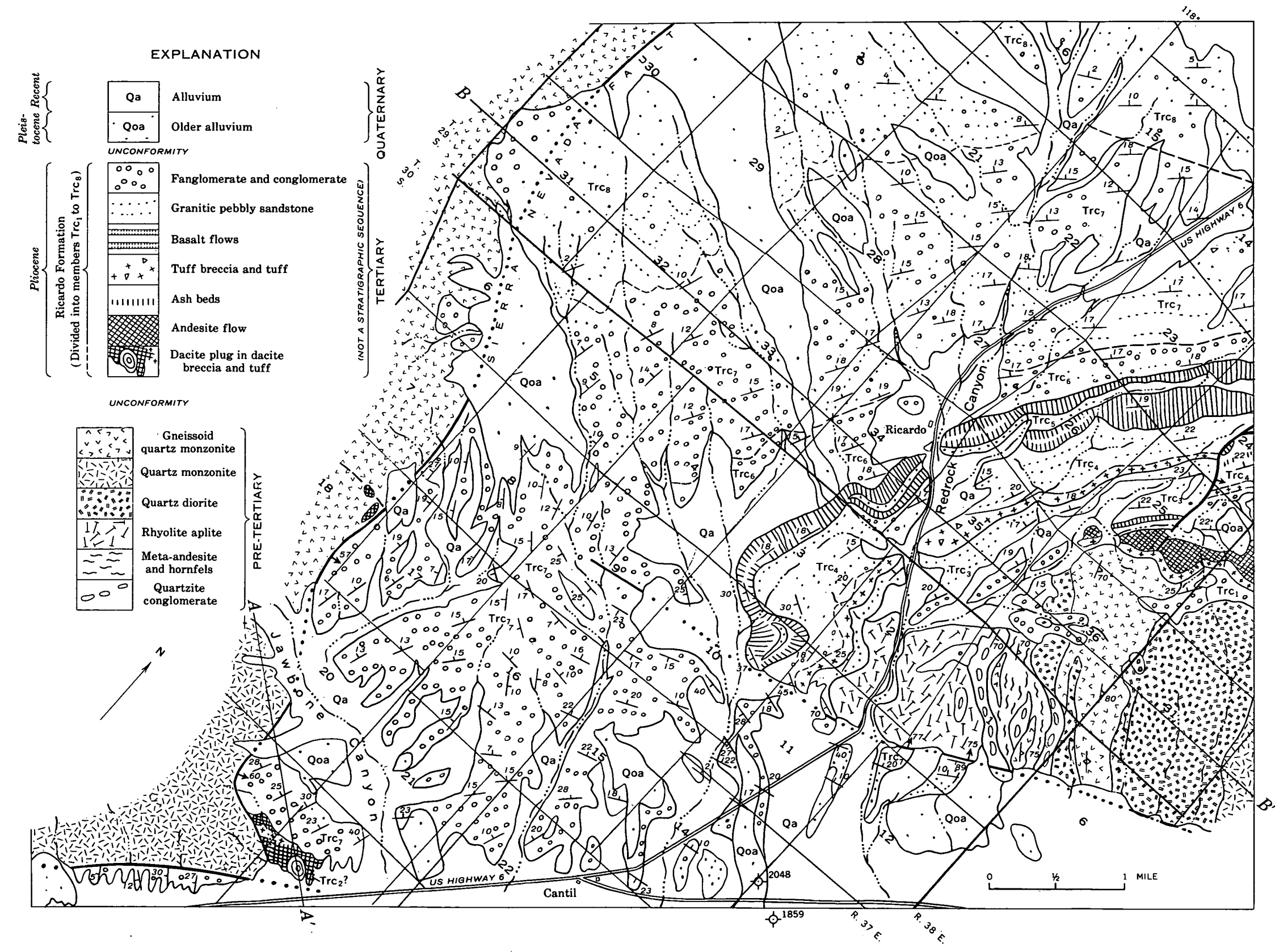




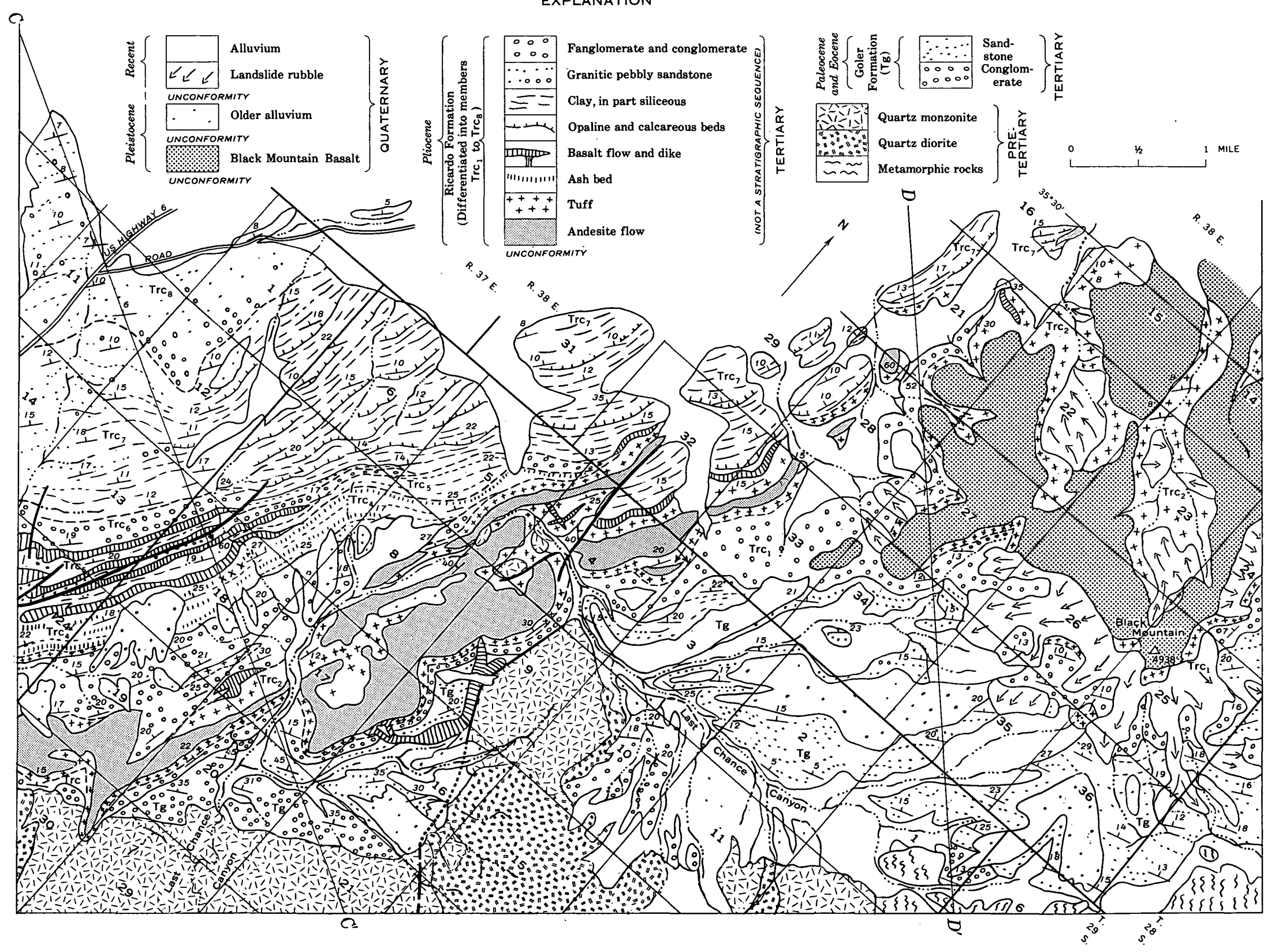

FToUre 64. - Cenozoic geology of Last Chance Canyon area, El Paso Mountains. 


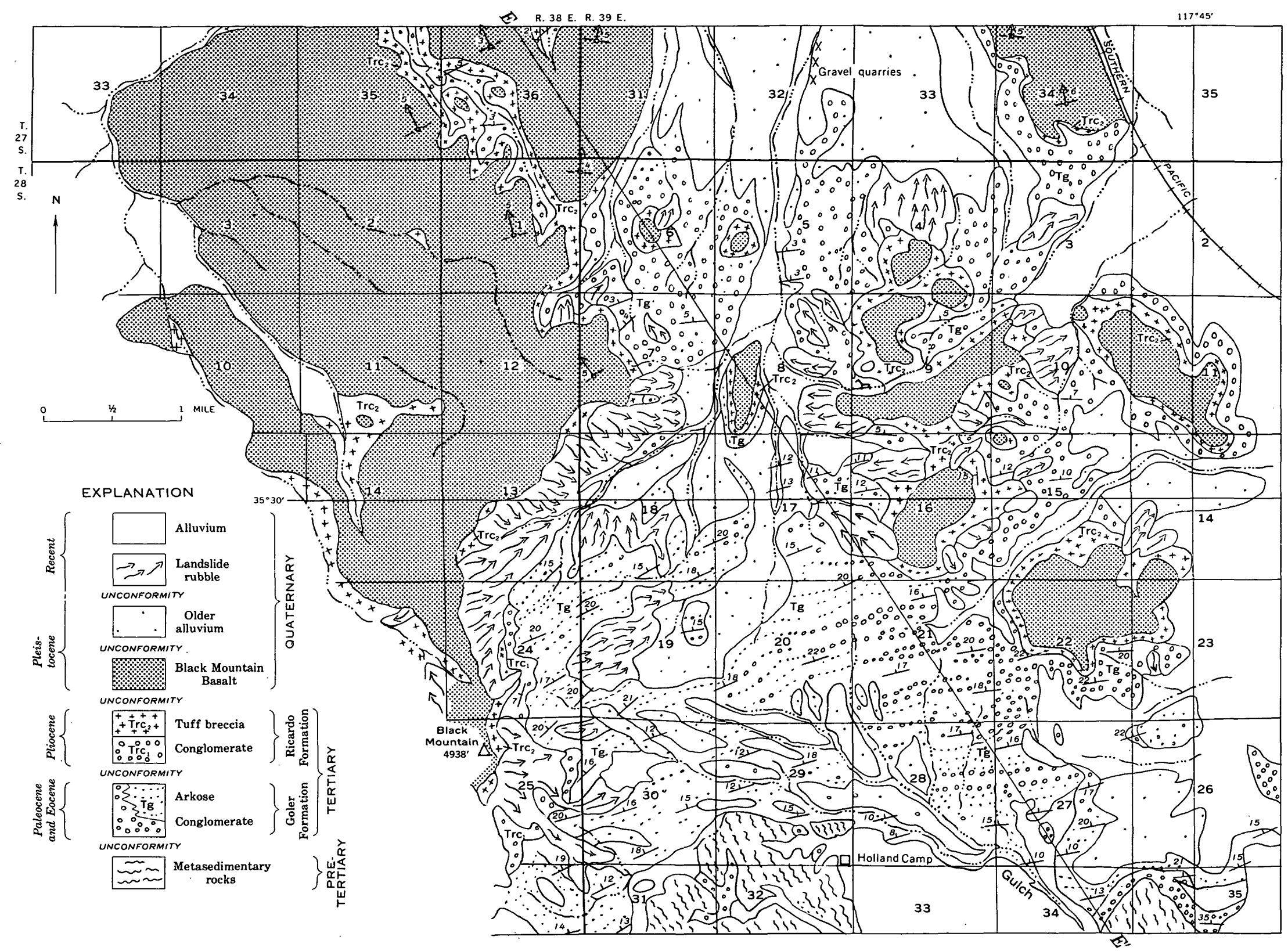



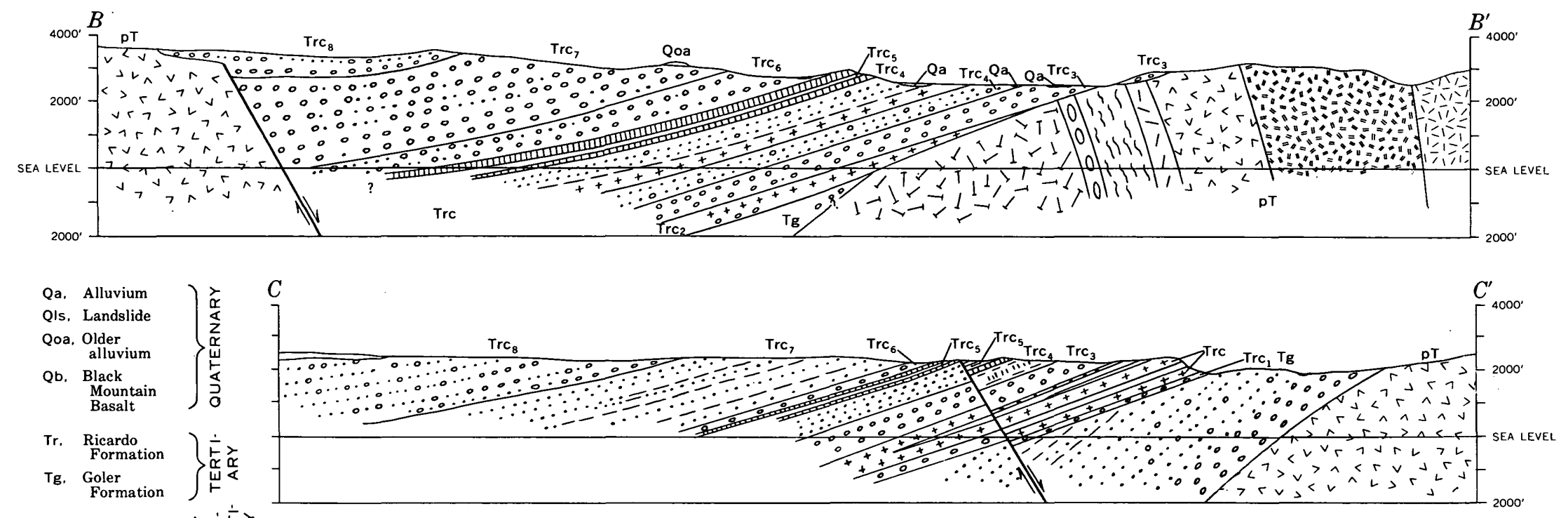

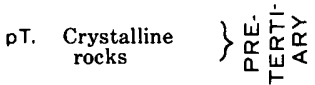
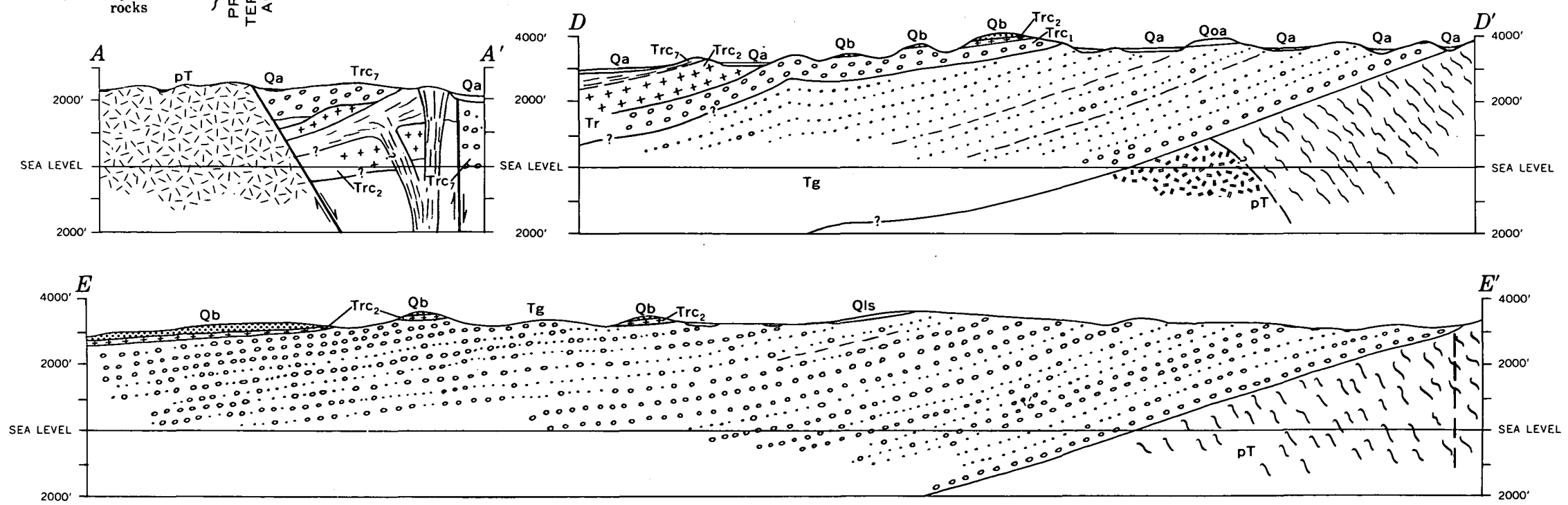

Frauke 66.-Sections of Redrock Canyon, Last Chance Canyon, and Goler Gulch areas, El Paso Mountains. Locations of section are shown on figures 63-65. 
Mammalian fossils of Ricardo fauna found mostly in beds (members 6 and 7) above basalt flows, near Ricardo in Redrock Canyon, described by Merriam $(1919$, p. 525-529) and assigned by him to early Pliocene (Clarendonian) age. Another mammalian fauna, and flora from beds (member 5) below Ricardo mammalian fauna also believed to be Clarendonian in age. Ricardo Formation therefore considered to be early Pliocene of the mammalian time scale.

\section{LAVA MOUNTAINS ARBA}

GRAY ANDESITE PROPHYRY

Two exposures of gray andesite porphyry, one across U.S. Highway 395, 2 miles east of Summit Diggings (fig. 68); other 1/4,-2 miles farther east (pl. 1). Rock intrusive, extrusive, or both. Apparently overlies quartz monzonite; in eastern exposure overlain by tuff of Bedrock Spring Formation; in western exposure, porphyry wedges westward into it.

Rock composed of scattered to numerous white phenocrysts of plagioclase (partly altered to sericite, albite, kaolinite, and calcite) and small black phenocrysts of hormblende (largely altered to limonite) in dark-gray aphanitic groundmass.

Rock probably same age as basal part of Bedrock Spring Formation, middle Pliocene, or possibly older.

\section{RHYOLITE FELSITE}

Rhyolite felsite exposed in eastern Rand Mountains; just south of Johannesburg, felsite forms volcanic mass intrusive into quartz monzonite, flanked on northwest by rhyolite flow breccia extrusive on quartz monzonite; generally vertical dikes of felsite as much as 30 feet wide radiate from intrusive mass (fig. 3).

At north end of Red Mountain, rhyolite felsite forms small volcanic plug with concentric flow laminae parallel to its vertical margin that is partly bordered by dark-gray vitrophyre. Plug either intrusive into or possibly buried by sandstone of Bedrock Spring Formation.

Felsite white, gray white to cream white, rarely pink; weathers buff; massive to faintly flow laminated, aphanitic to slightly porphyritic; composition presumably ranging from rhyolite to quartz latite; according to Hulin (1925, p. 49-50) composed mainly of orthoclase and quartz, with minute amounts of muscovite, biotite, green hornblende, magnetite, and pyrite; contains scattered small phenocrysts mostly of orthoclase and quartz.

Age relationship of rhyolite felsite to Bedrock Spring Formation controversial, as indicated by field relation of small plug at north end of Red Mountain.
Abundance of felsite dikes in pre-Tertiary rocks, their absence in Bedrock Spring Formation, and abundance of felsite fragments in Bedrock Spring Formation suggest felsite is older than that formation. Felsite therefore middle Pliocene or older, possibly Miocene, in age.

\section{BEDROCK SPRING FORMATION}

A sequence of fluviatile sedimentary and some pyroclastic rocks of Pliocene age unconformable on Mesozoic quartz monzonite and overlain by andesitic volcanic rocks exposed in Lava Mountains, mostly beyond northeast border of mapped area; also exposed on slopes of Red Mountain and near Summit Diggings (pl. 1). Referred to Rosamond Series (of former usage) by Hulin (1925, p. 42-48, pl. 1); in Lava Mountains mapped and described in detail and named after Bedrock Spring by Smith (1964). Type section near Bedrock Spring in Lava Mountains, beyond northeast border of mapped area, where formation is as much as 5,000 feet thick.

In Red Mountain area Bedrock Spring Formation probably about 5,000 feet or more thick; thins southwestward by onlapping against pre-Tertiary rocks as indicated from mine workings near town of Red Mountain; intruded by andesite (fig. 67). Sequence composed mostly of light-buff to locally green and red sandstone and lesser amounts of interbedded conglomerate, green to red siltstone, and occasional bed of white tuff. Pebbles of conglomerate mostly of granitic rocks, few of rhyolite felsite and of Rand Schist. Rhyolite breccia composed of angular fragments of tan rhyolite felsite.

Near Garlock fault northeast of Summit Diggings, about 1,900 feet of strata referred to Bedrock Spring(?) Formation exposed in anticline, but almost entire sequence onlaps(?) against quartz monzonite to east (fig. 68) ; lowest 1,000 feet of formation composed of gray-white, green, and pink arkosic sandstone, some interbedded andesitic and granitic pebble-cobble conglomerate, and green-gray to red siltstone; upper 900 feet, which may be basal part of andesite volcanic complex rather than Bedrock Spring Formation, composed of about 100 feet of bentonite and fine-grained bedded tuff which grades upward into about 800 feet of white coarser tuff and lapilli-lithic tuff breccia.

Mammalian fossil remains in Bedrock Spring Formation in eastern Lava Mountains (4-6 miles eastnortheast of Klinker Mountain) considered to be younger than Ricardo fauna, or probably middle Pliocene of the mammalian time scale (G. E. Lewis in Smith, 1964, p. 21). 


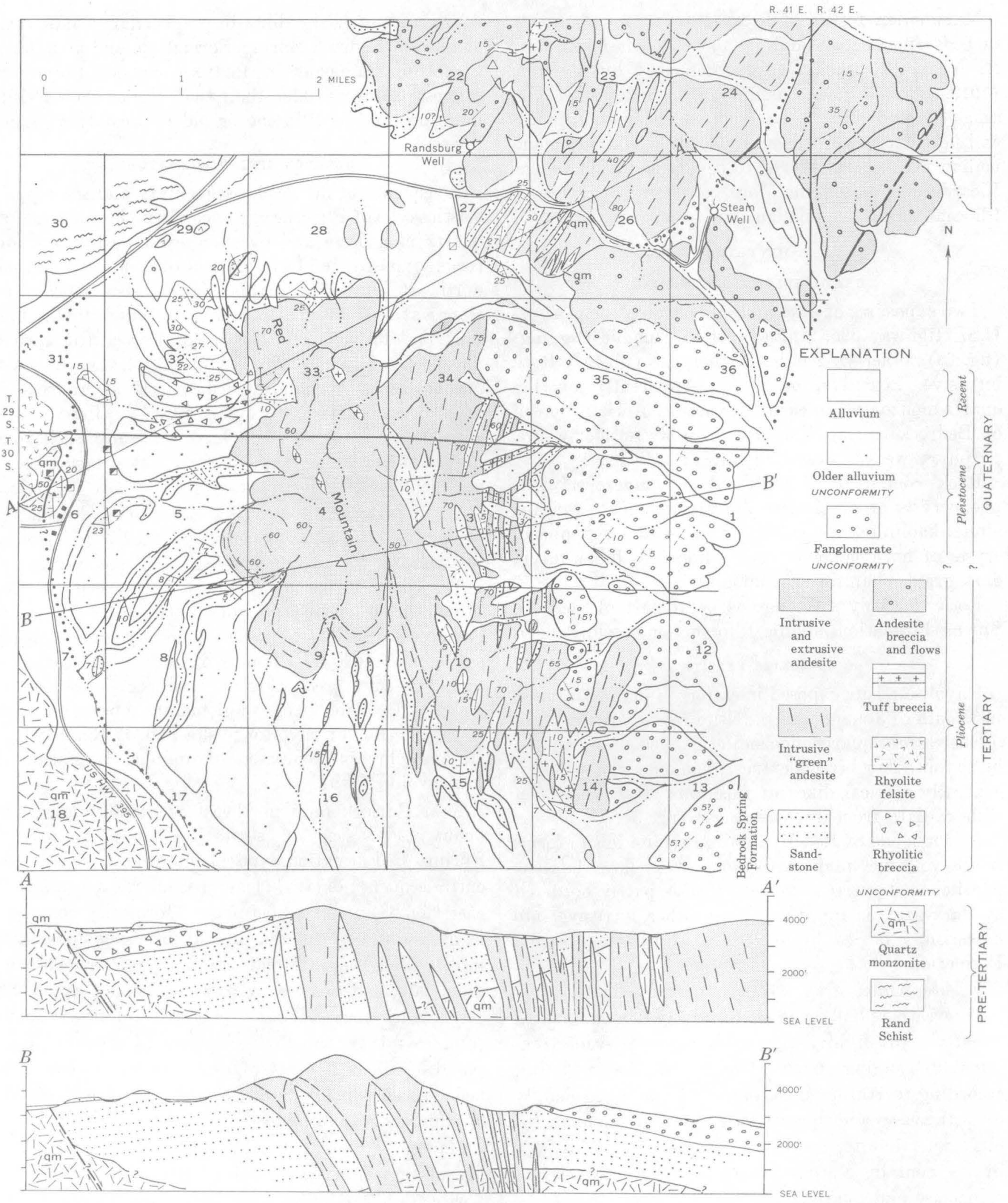

Frgure 67.-Geologic map and sections of Red Mountain area. 


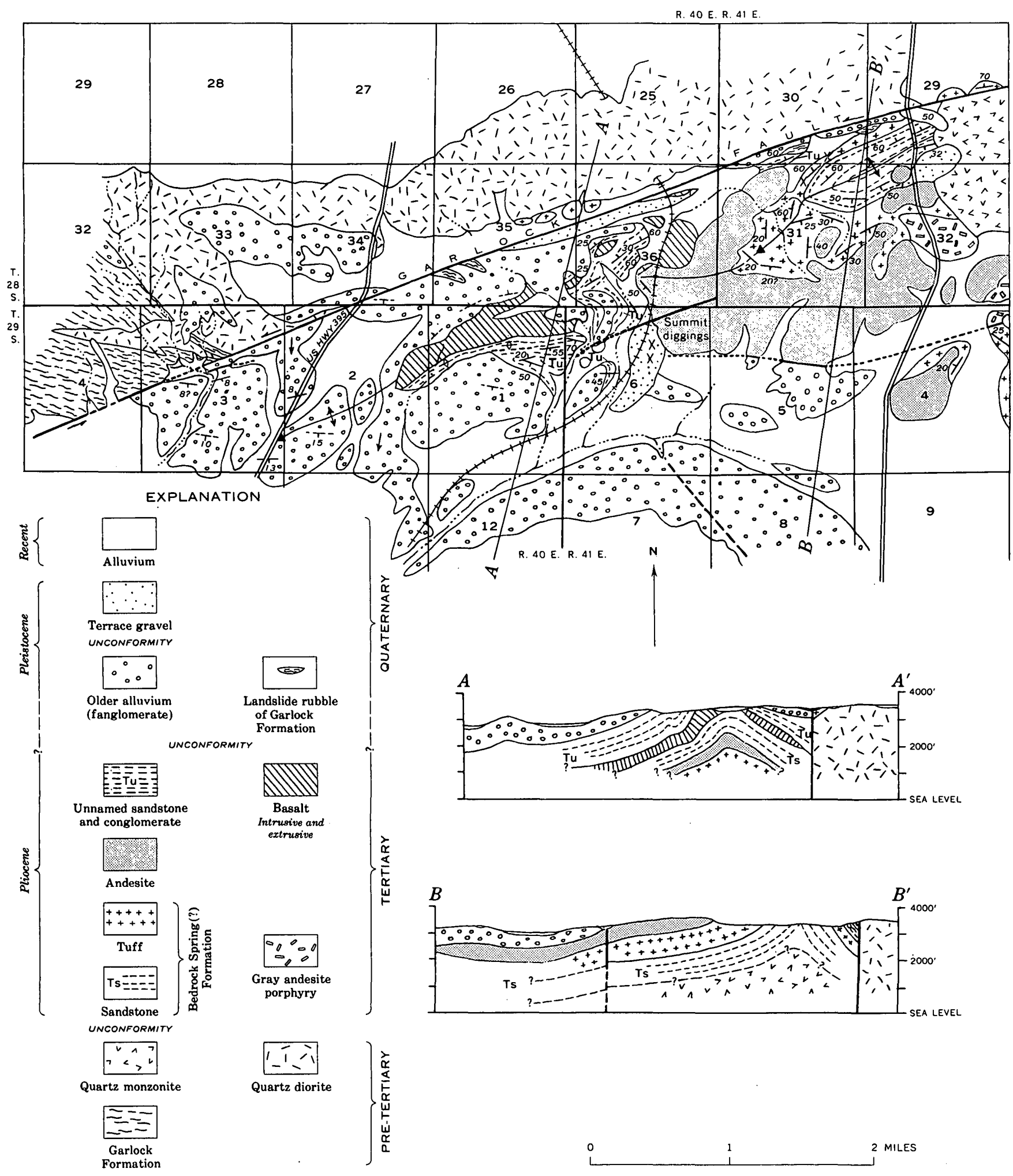

FIGURE 68.-Geologic map and sections of Summit Diggings area. 


\section{ANDESITE}

Porphyritic andesite of Pliocene age intrusive into and extrusive on Bedrock Spring Formation prominently exposed in Lava Mountains, Summit Diggings area, and Red Mountain (pl. 1). Mapped and described as Red Mountain Andesite by Hulin (1925, p. 55-58, pl. 1), but name no longer applied to this volcanic unit. In Lava Mountains, mapped in detail by Smith (1964).

Andesite divided into three units (pl. 1), all gradational and not everywhere distinct: intrusive andesite, andesite breccias and flows and andesite flows.

Andesite of all three units petrographically similar; unaltered andesite massive, porphyritic. Most phenocrysts white, rectangular, of plagioclase (andesine, $\mathrm{An}_{30}{ }^{-50}$ ), as much as $6 \mathrm{~mm}$ long; make up 10-30 percent of rock mass; other phenocrysts smaller, black prismatic, of hornblende (oxyhornblende) and pyroxene (clinopyroxene and orthopyroxene). Groundmass aphanitic, locally subvitreous, medium gray (Smith, 1964). In places andesite hydrothermally altered to propylite having phenocrysts of feldspar partly replaced by sericite, albite, and calcite and phenocrysts of ferromagnesium minerals replaced by sericite, calcite, epidote, chlorite, and opaque minerals (Smith, 1964).

Intrusive andesite forms much of southern Lava Mountains and most of Red Mountain. This andesite generally massive but in places has indistinct fracture parting parallel to outer walls of intrusive masses. In Lava Mountains, intrusive andesite occurs as two main types: purple to brown andesite and green andesite, although there are intermediate types. In many places, partly to wholly altered to propylite (Smith, 1964). Purple to brown andesite ranges from purple through blue gray and pink gray to brown; forms irregular complex masses intrusive into and gradational into andesite breccias and flows. Green andesite ranges from olive green to olive brown; occurs as numerous parallel, nearly vertical merging dikes and pods that trend west of south from southern Lava Mountains into east slope of Red Mountain; intrusive into quartz monzonite and Bedrock Spring Formation (fig. 67).

On Red Mountain, andesite intrusive through Bedrock Spring Formation (fig. 67) ; lower parts of andesite bodies olive green; upper parts olive to reddish brown; highest parts may be partly extrusive onto depositional surface of Bedrock Spring Formation as suggested by local brecciation of andesite near contact and by dip of contact inward toward intrusions.

Andesite breccia and flows (Almond Mountain
Volcanics of Smith, 1964) exposed extensively in western and southern Lava Mountains; gradational into associated intrusive andesite; overlie Bedrock Spring Formation, in places unconformably(?). Composed of mixture of irregular flows, flow breccia, and andesite cobble-boulder breccia or conglomerate; colors vary from purple to pink gray to brown. Lenses of pink and buff to white tuff, arkosic sandstone, and conglomerate, as much as 50 feet thick, present locally near base and near top; total thickness of andesite unit unknown, but probably more than 1,000 feet, possibly 2,000 feet; unit locally hydrothermally altered.

Andesite flows (Lava Mountains Andesite of Smith, 1964) in Lava Mountains occur as isolated flows as much as 100 feet thick of dark-brown to reddish-brown andesite that cap andesite breccias and flows in Klinker Mountain area, lap northward unconformably (?) onto Bedrock Spring Formation (pl. 1).

In Summit Diggings area, andesite rests on Bedrock Spring (?) Formation, in places unconformably; may be as much as 300 feet thick; possibly in part intrusive; ranges from dark brown to light gray to rusty brown. Overlain by unnamed sedimentary rocks and basalt to west (pl. 1; fig. 68).

Andesite younger than middle Pliocene Bedrock Spring Formation that it intrudes and upon which it rests, and older than fanglomerate of probable Pleistocene age that unconformably overlies it (fig. 67), thus presumably late middle to late Pliocene age, most probably late Pliocene in age.

\section{UNNAMED SANDSTONE AND BASALT}

Sequence of sandstone and basalt, apparently overlying andesite and unconformably overlain by Quaternary fanglomerate, exposed between Summit Diggings and Garlock fault. Sandstone included by Hulin $(1925$, p. 58-60, pl. 17, pl. 1) in Rosamond Series of former usage and basalt described and mapped. by him as Black Mountain Basalt.

Sequence and structure of formation shown on figure 68. Formation about 1,800 feet thick; lowest 700 feet indistinctly bedded friable light-buff arkosic sandstone, in places containing pebbles of granitic rock and rhyolitic felsite; includes local lenses of gray to red micaceous siltstone. Overlain by flow (or sill?) of weathered basalt having possible maximum thickness of 500 feet, thinning northeastward; presumably flowed from vent now filled with plug of hard basalt twothirds of a mile north of Summit Diggings; basalt microcrystalline, composed of lath-shaped feldspars, magnetite, and glass; contains scattered phenocrysts of plagioclase (labradorite-bytownite), brown horn- 
blende (partly replaced by magnetite), and augite (Hulin, 1925, p. 60).

Basalt overlain by about 900 feet of buff arkosic sandstone that forms uppermost part of formation; includes some thin intercalations of micaceous shale, somewhat siliceous, in exposure three-fourths of a mile N. $30^{\circ} \mathrm{W}$. of Summit Diggings; in exposures west of Summit Diggings, lowest 300 feet of very hard thickbedded sandstone that forms resistant ledges; rest of sandstone soft and friable.

No fossils found in formation. Presumably late Pliocene in age, younger than andesite and older than unconformably overlying fanglomerate of Quaternary age.

\section{QUATERNARY SEDIMENTARY DEPOSITS AND BASALT OLDER ALLUVIUM}

Older alluvium, presumably of Pleistocene age, composed of semiconsolidated fanglomerate, gravel, sand, silt, and clay, underlies much of Mojave Desert. As much as 1,000 feet or more thick; presumably underlies Recent alluvium of all valley areas. Exposed and dissected in former valley areas slightly elevated by late Quaternary crustal movements.

In Mojave Desert between Rosamond and Barstow areas, fanglomerate (pl. 1) in part underlies and therefore in part older than remainder of older alluvium; as much as 600 feet or more thick. In exposures between Rosamond and Hinkley, fanglomerate composed of unsorted boulders and cobbles mostly of granitic rocks. In exposures southeast of Mojave River, fanglomerate composed of cobbles derived from Mesozoic plutonic rocks and porphyry complex. At Red Mountain, fanglomerate composed of andesite detritus. Remainder of older alluvium, as much as 700 feet thick, composed of gravel and sand derived from nearby exposures of pre-Tertiary and Tertiary rocks. North of Hinkley includes some lacustrine clay and marl.

Along southern margin of Mojave Desert and Cajon Pass, older alluvium forms dissected north-sloping piedmont alluvial fan that was elevated by northward tilt and beheaded by Cajon Creek drainage system (pl. 1, figs. 31, 32, 33). Older alluvium of this area conformable on Crowder Formation where present, lapping onto pre-Tertiary rocks; about 1,000 feet thick; composed of coarse gravel derived from plutonic rocks, gneissic rocks, and Pelona Schist of San Gabriel and San Bernardino Mountains. In large part mapped by Noble (1954a, 1954b) as Shoemaker Gravel. In Cajon Pass area lower 300 feet (figs. 31, 32) composed of greenish-gray finer gravel, sand, and silt.

In San Gabriel Mountain foothill area westward from Valyermo, older alluvium unconformable on Ter- tiary and pre-Tertiary rocks; as much as 400 feet thick; composed of coarse gravel; in places lower part composed of greenish-gray finer gravel, sand, and silt (included in Harold Formation as mapped by Noble, 1953, 1954b) as in Cajon Pass area. Two distinct facies mapped (pl. 1, figs. 27, 28, 29) : gravel of mostly granitic detritus, and gravel of mostly Pelona Schist detritus (northeast of San Andreas fault in part mapped by Noble, 1953, as Nadeau Gravel).

In Tehachapi Mountain foothills, older alluvium as much as 1,000 feet thick where exposed by crustal movements and dissection; upper part, as much as 400 feet thick, is coarse gravel; lower part, as much as 500 feet thick, is finer gravel and interbedded reddish- to greenish-gray silt and gray to buff sand; exposed only locally (figs. 69, 12, 62).

Terrace gravel, present as erosional remnants (pl. 1), deposited on erosion surface cut into older alluvium and older formations. In Cajon Pass area (fig. 31), terrace gravel south of Horsethief Canyon composed of Pelona Schist detritus. Three deposits southwest of Cajon Creek are landslide debris of quartz diorite and gneissic rocks.

Older alluvium generally unconformable on formations of Pliocene age and underlie Recent alluvium, therefore most if not all of older alluvium probably Pleistocene in age. In places lowermost beds may extend down into very late Pliocene.

\section{BLACK MOUNTAIN BASALT}

Basalt presumably of Pleistocene age exposed over wide area as a thin sheet of one or more lava flows less than a total of 100 feet thick on Black Mountain north of El Paso Mountains (pl. 1). Overlies Ricardo Formation with no visible discordance; farther east lies on Goler Formation (fig. 26). Basalt of this area named by Baker (1912); mapped by Dibblee (1952), p. 30, pl. 1 ), and name officially adopted for use in this report.

Also exposed on Black Mountain southwest of Opal Mountain, and east of Opal Mountain (pl. 1; figs. 65, 69 ). In both these areas basalt sheet as much as 150 feet thick; thins out in all directions, in one place into older alluvium; overlies beveled surface of Barstow and Pickhandle Formations; laps eastward onto Mesozoic quartz monzonite and Lane Mountain Andesite; in part deformed, elevated, and dissected. Basalt penetrated by several test holes in Harper Valley.

Basalt black, hard, fresh, vesicular, very fine grained, ophitic; composed mostly of plagioclase (labradorite), pyroxene, and small amounts of olivine and iron oxides.

Black Mountain Basalt presumably of Pleistocene age, as indicated by (1) unconformable relationship on formations of Tertiary age as young as Pliocene, 

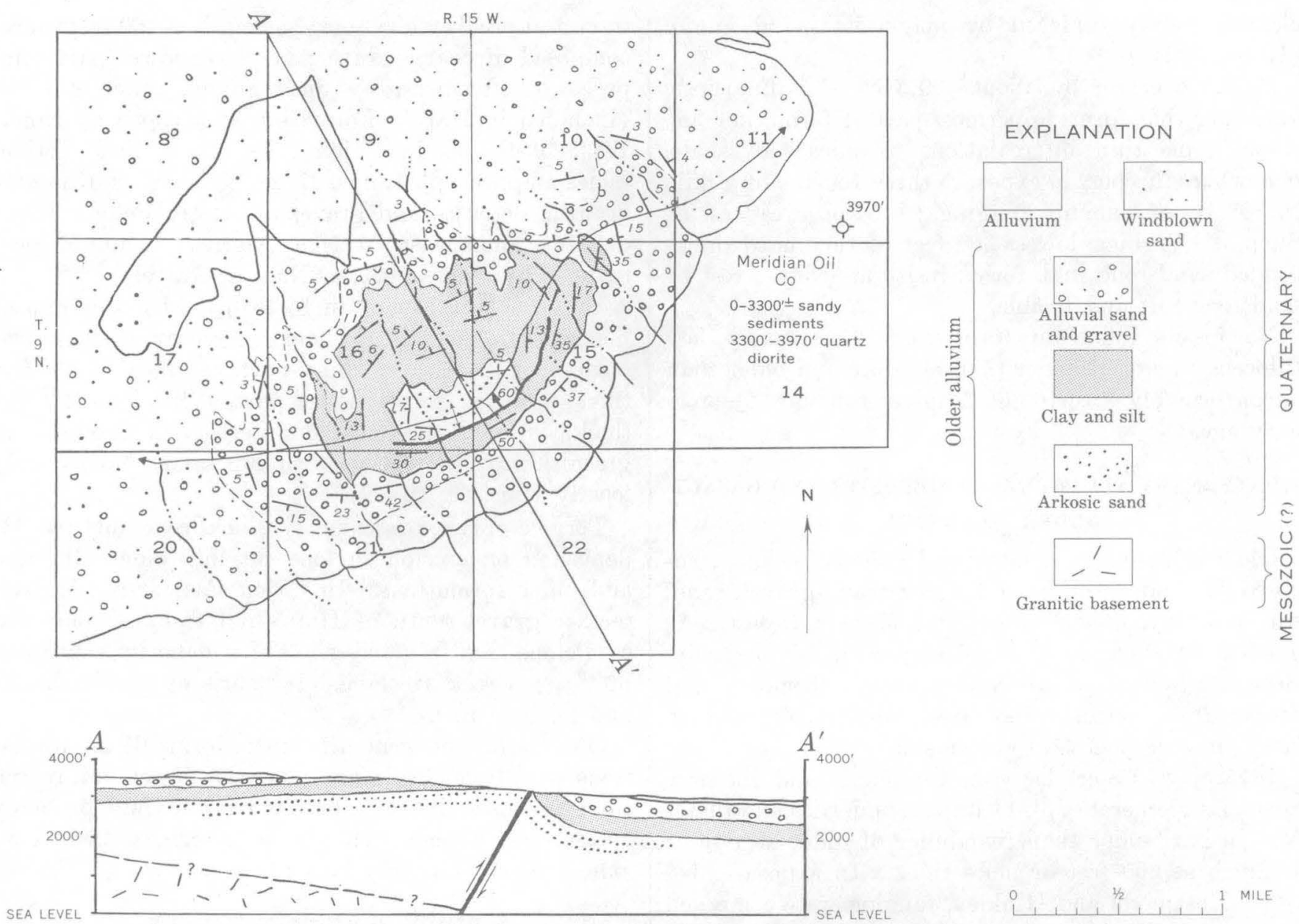

MILE

Figure 69.-Geologic map and section of Sand Hills.

(2) lensing out into gravel of older alluvium 5 miles east of Opal Mountain, and (3) preservation of top surface of lava flow throughout most exposures.

\section{ALLUVIUM}

Generally undissected alluvium of Recent and possibly very late Pleistocene age covers desert valleys and flood plains of all streameut valleys and canyons within mapped area. As much as 100 feet thick; in broad desert valleys gradational downward into older alluvium; elsewhere unconformable on older alluvium and on all older formations.

Alluvium composed of unconsolidated detrital sediments derived from adjacent highland areas; following facies of alluvium recognized, all gradational into each other: fan alluvium, valley alluvium, river sand, and sand bars.

Fan alluvium forms alluvial fans of coarse detritus deposited at foot of mountains and hills; composed of fanglomerate, gravel, and coarse sand of angular to subrounded fragments as large as several feet; extends far up flood plains of canyons; top surface slopes as much as 500 feet per mile.

Fan alluvium grades downslope into valley alluvium of broad desert plains and valley; composed of gravelly sand, sand, sandy silt, and clay; deposited by streams as outwash from alluvial fans; top surface nearly level, slopes 5-200 feet per mile.

River sand fills stream channels of Mojave River and some channels of larger washes; sand well sorted, medium to fine. Deposited by ephemeral streams that flow only for several days, weeks, or months each year.

Around and near margins of large playa lakes, valley alluvium locally covered with thin, elongate bars of coarse- to medium-grained sand parallel and concentric to margin of playas; these are sand bars evidently deposited by waves along shorelines of receding ancient lakes that once filled these lowland areas. 


\section{WINDBLOWN SAND}

Loose buff well-sorted fine-grained sand deposited by prevailing westerly winds in form of closely spaced dunes or thin cover on many parts of desert (pl. 1). Windblown sand most extensive on east margin of Antelope Valley; forms numerous dunes between Rosamond and Rogers Lakes, some dunes forming rims around east side of small playa lakes; forms extensive veneer on broad west slope of low hills east of Rogers Lake. East of Harper Lake, sand forms irregular dunes; elsewhere sand forms thin surface layer.

\section{PLAYA CLAY}

Clay or mud forms level floor of existing playa lakes in lowest parts of undrained desert valleys; clay gray, finely micaceous; generally alkaline, especially on larger playas where mostly sodium carbonate and sodium chloride cover playa surface after evaporation of saline water following infrequent heavy rains; clay of Koehn Lake highly alkaline. Playas devoid of vegetation owing to alkalinity of clay. Clay soft and pliable when wet, firm when dry.

\section{GEOLOGIC STRUCTURE}

The major structural features of the western Mojave Desert are shown on plate 1; structural details of areas within it are shown on the figures throughout the section "Rock units."

The basement complex of pre-Tertiary crystalline rocks of the Mojave block and adjacent areas is mainly a granitoid batholith, presumably the southern extension of the Sierra Nevada batholith that is generally devoid of discernible structure. It contains isolated unassimilated remnants of intensely deformed metamorphic rocks (pl. 1).

The dominant Cenozoic tectonic features of the Mojave block are the high-angle San Andreas and Garlock faults which bound it (pl. 1) and along which mountain ranges were elevated. The fact that high-angle major faults within the block are generally parallel to these master faults suggests that they are genetically related.

\section{TERTIARY DEPOSITIONAL BASINS}

The Cenozoic structure of the Mojave block consists of large elevated areas of basement complex separated by extensive valley areas or basins filled with Cenozoic deposits. The Tertiary formations that overlie the basement complex as erosional remnants on the elevated areas are much deformed by tilting, folding, and faulting. Structural trends of fold axes in Tertiary rocks throughout the western Mojave Desert are gen- erally eastward. Quaternary deposits that cover the basins and lap onto the eroded surface of Tertiary and basement rocks of the elevated areas are themselves locally deformed in the same manner, mostly near faults, but to a much lesser degree (pl. 1). In the basins, Cenozoic deposits extend to depths of several thousand feet as indicated from logs of some deep test holes (table 4).

In order to shed light on the probable areal extent and configuration of the basins filled with Cenozoic deposits, which are low-density materials as compared to the pre-Tertiary crystalline rocks, a gravity geophysical survey was made of the entire area by Mabey (1960). His report includes a gravity map as well as a detailed description and interpretation of the gravity variations.

Figure 70 shows the gravity variations generalized after Mabey (1960, pl. 10). Figure 71 shows the probable areal extent of basins filled with Tertiary deposits, based upon their known outcrop distribution, their probable concealed areal extent as inferred from the gravity data shown on figure 70, and from logs of several test holes. Figure 71 also shows probable profiles across the major basins shown, based on interpretations of the gravity data by Mabey (1960).

From figure 71 it may be noted that most of the depositional basins are elongated generally eastward. The large areas of basement complex that separate the basins were probably in large part highlands that were elevated as the basins were depressed; if so, they must have shed detritus into the basins during Tertiary time. This condition is suggested by the great difference in the sequence in each basin and by the coarsening of some formations toward the basin margins. The local sequences shown on plate 4 were deposited in the basins shown on figure 71 as indicated on that plate.

\section{FAOLTS}

The San Andreas fault, which forms a straight trenchlike feature bearing about N. $65^{\circ} \mathrm{W}$. through the mountains and hills along the southwest margin of the western Mojave Desert, is a vertical shear zone of gouge and crushed rock a few tens to several hundred feet wide. Parts of this 90-mile segment are described in detail by Noble $(1953,1954 a$, b, p. 44-66), Wallace $(1949$, p. $792-797)$, and Crowell $(1952$, p. $18-20)$. The fault is highly active as indicated by recently formed scarps, shutter ridges, sag-ponds, offset stream channels, and small ridges. All these features indicate active right-lateral or horizontal southeastward movement of the northeastern side relative to the southwestern side. Other parallel faults such as the Punchbowl and Nadeau faults are less active but have the 


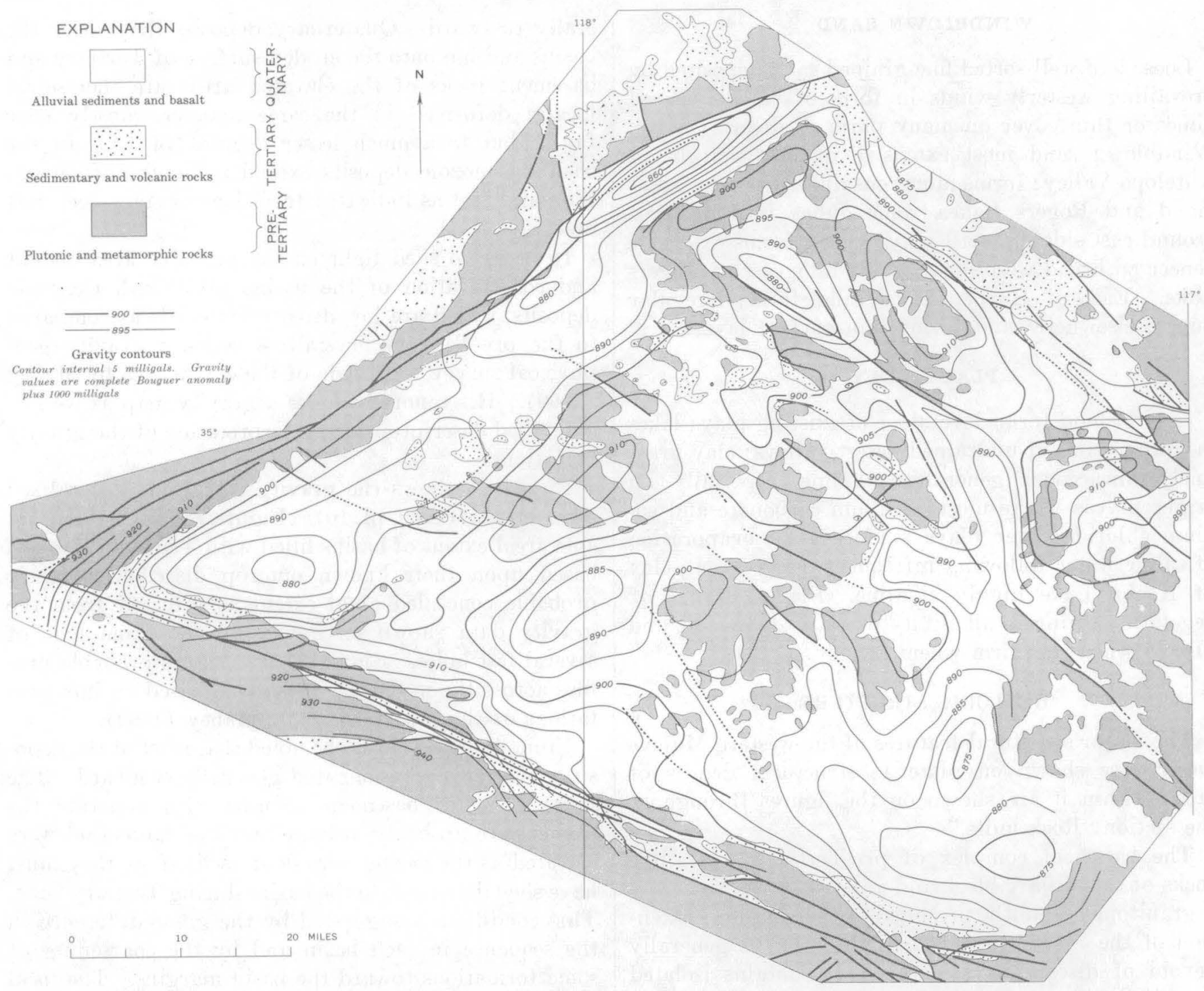

Figure 70.-Bouguer anomaly and generalized geologic map of western Mojave Desert. Gravity anomaly contours after Mabey (1960).

same type of displacement and are part of the San Andreas fault zone.

The older alluvium is everywhere truncated, displaced, and locally folded by lateral movements on the San Andreas fault. Old dissected piedmont fans on the northeast side of the fault, derived from mountains southwest of it, are generally displaced southeastward from their source. The most striking example of this shift is the older alluvium composed of Pelona Schist detritus present as erosional remnants of a piedmont fan on the northeast side of the San Andreas fault between Palmdale Reservoir and Little
Rock Creek. This older alluvium must have been deposited at the northeastern base of the Pelona Schist exposure of Sierra Pelona from which it was derived (pl. 1). It is displaced by right lateral movement on the fault about 7 miles southeast and is now adjacent to older alluvium of granitic detritus across the fault (figs. 27, 28).

Cumulative right-lateral displacement on the San Andreas fault zone since early Pliocene time may have been as much as 40 miles, as suggested on figure 72 .

The Garlock fault is a northeast-trending zone of high-angle faults along which movements have been 

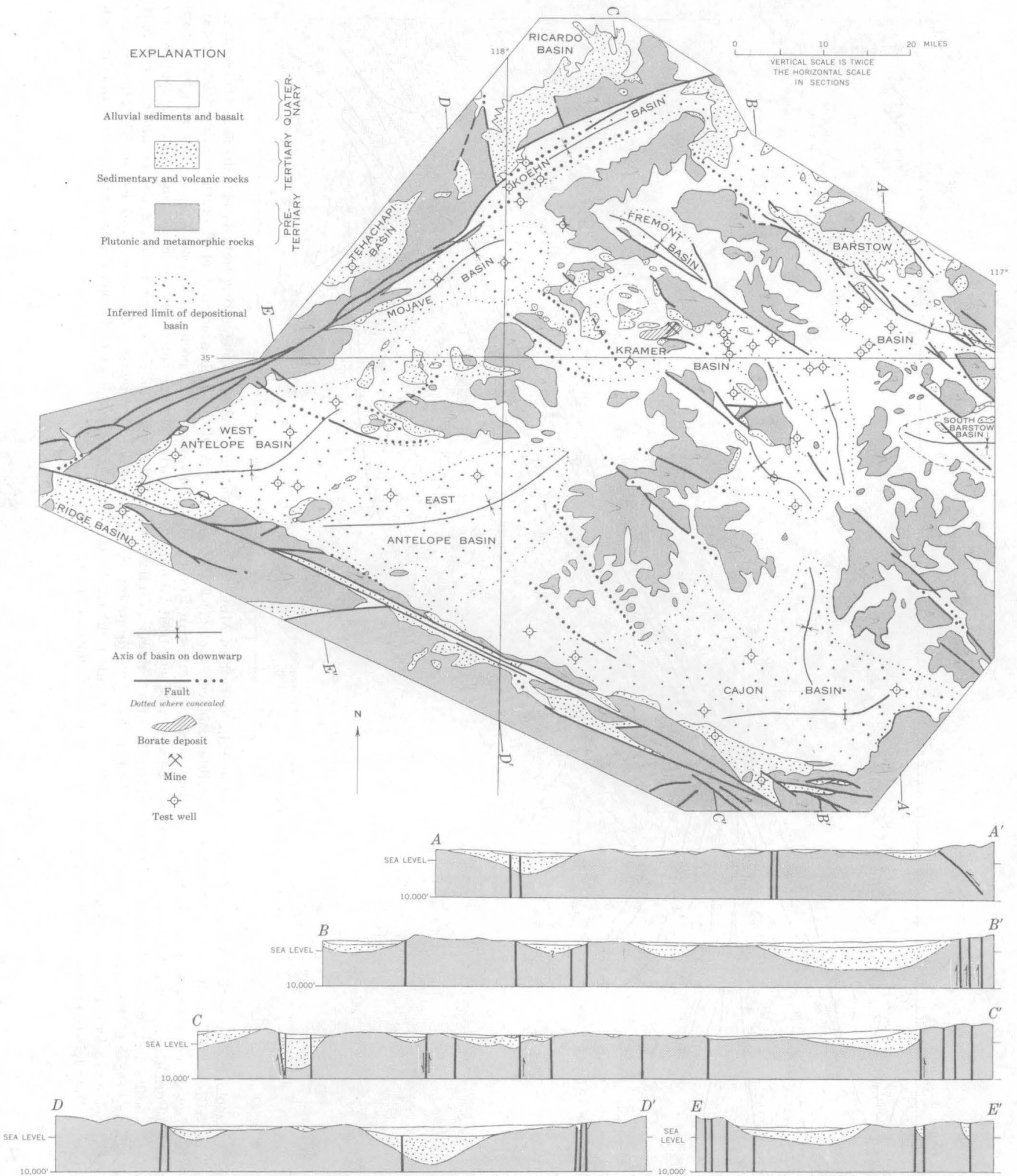

Figure 71.-Probable areal extent of depositional basins filled with sedimentary and volcanic rocks of Tertiary age in western Mojave Desert, and their inferred profiles and depth, as based on surface exposures, gravity data, and data from test wells shown. 


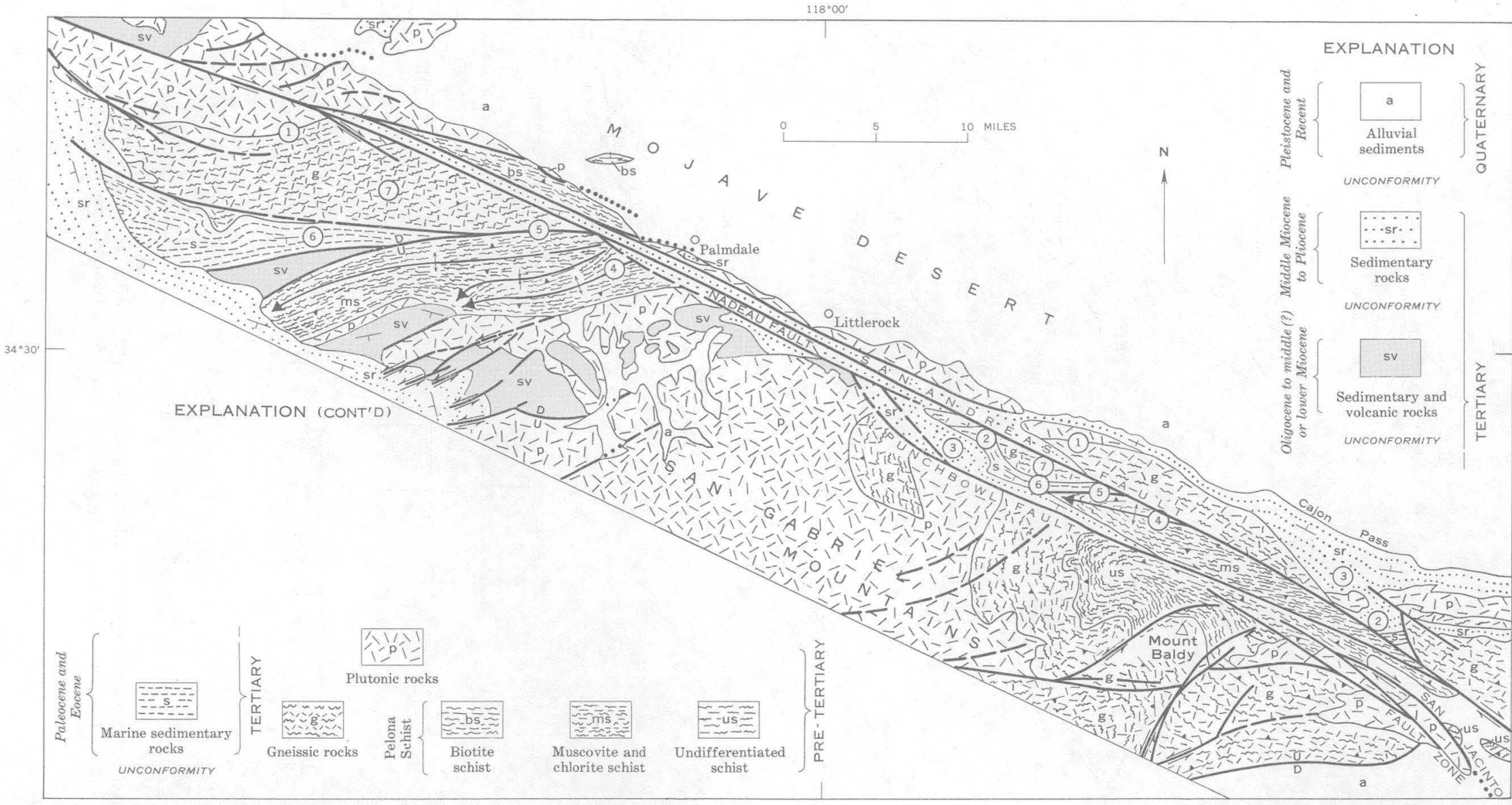

FIGURE 72.-Simplified geologic map of San Andreas fault zone at margin of western Mojave Desert, showing evidence suggesting right-lateral displacements, measurable in miles, on San Andreas fault and its branches. Possible displaced geologic features on San Andreas fault are: contact of plutonic and gneissic rocks, pre-Tertiary (1), offset or separated at least 35 miles since pre-Tertiary time; San Francisquito Formation, Paleocene and Eocene(?) (2), overlain by eastern facies of Punchbowl Formation, upper Miocene and lower Pliocene (3), offset about 20 miles since early Pliocene time. Possible displaced geologic features on Nadeau-Punchbowl faults are: anticlinally folded Pelona Schist (4), offset about 23 miles; old inactive fault (5), bounding Pelona Schist on north and in part buried by sedimentary rocks of Miocene age, offset about 27 miles; southward-dipping San Francisquito Formation, Paleocene and Eocene(?) (6), overlying eastward-striking gneissic rocks (7), offset about 20 miles. Note 2- to 6-mile right-lateral displacements of contact of Pelona Schist and plutonic rocks on San Jacinto fault zone. Note left-lateral displacements on most faults trending north of east. 
predominantly left lateral of which southeastern block has moved northeastward relative to the northwestern block (Hill and Dibblee, 1953, p. 451). The amount of total displacement is not known. Hulin (1925, p. 62-64) suggests displacement of about 6 miles near Randsburg, but G. I. Smith (1960) suggests a displacement of possibly 40 miles based on offset(?) of a dike swarm west of Searles Lake north of the fault from a similar dike swarm south of the fault about 40 miles east.

The topographic expression of the Garlock fault or its bifurcations is similar to that of the San Andreas. It is therefore presumably vertical. The fault has been highly active since deposition of the older alluvium which it breaks. Although there are evidences of local vertical components of displacement, the greater movement was predominantly left lateral as indicated or suggested by the following evidence:

1. Southeastward-draining stream channels are offset eastward as they cross the fault, some nearly as much as half a mile in the eastern El Paso Mountains; northwestward-draining channels from the Lava Mountains are offset westward.

2. A wave-deposited bar of coarse sand on the northeast margin of Koehn Lake is offset about 150 feet left laterally.

3. Trenches in an elevated fan of older alluvium north of the fault and west of Garlock as deep as 40 feet and as wide as 200 feet trend N. $30^{\circ}$ E., as compared to the $\mathrm{N} .60^{\circ} \mathrm{E}$. trend of the fault (fig. 21) ; trenches are apparently minor tension grabens formed by a left-lateral drag movement on the fault, as suggested by $\mathrm{Hill}$ and Dibblee (1953, p. 451).

4. On the south side of the fault in Summit Diggings area, a deformed piedmont fan of older alluvium which was derived from the Garlock Formation of the El Paso Mountains and which includes landslide masses of the Garlock Formation was displaced at least 4 miles eastward from its original position adjacent to the Garlock Formation of the El Paso Mountains on the north side of the fault.

5. At the northeast end of Lava Mountains and 1 mile south of the fault (12 miles beyond northeast border of mapped area), Tertiary strata are underlain by shattered black phyllite, chert, and rusty-gray limestone similar to and possibly part of the Garlock Formation of the El Paso Mountains; if so, it is displaced at least 17 miles from that formation north of the fault.

6. Regionally southeast-trending foliation in gneissoid quartz diorite in the Tehachapi Mountains north of the fault curves eastward on approaching the fault and thus suggests a left-lateral drag movement.

7. If the Rand Schist in the Rand Mountains extends westward under Koehn basin to the Garlock fault, it may have been displaced about 30 miles from identical Pelona Schist in the Garlock fault zone in the Tehachapi Mountains (pl. 1).

The northwest-trending faults within the Mojave block are vertical or high angle, as indicated by their straight traces and some exposures. They transect, or in a few places bound, elevated areas of small vertical displacements. Some extend into the alluviated basins but none are known to cross them. Most of these faults show evidence of right-lateral displacements, as on the San Andreas fault, but of small magnitudes (Dibblee, 1961a, p. B197-B199; 1960d, p. 117, 119, 120; indicated or suggested by displaced contacts (figs. 5, 12,57 ), offset axes of east-trending folds (figs. 52, 54, 55,57 ), and associated east-trending drag folds (figs. $52,53,56,57)$.

The northeast-trending faults in the Rosamond and Kramer Hills (figs. 39, 50) are northwest-dipping normal faults showing no evidence of lateral movement.

\section{PRESENT TECTONIC ACTIVITY}

Movements in and adjacent to the western Mojave Desert after deposition of the older alluvium and eruption of the Black Mountain Basalt of Pleistocene age are shown on figure 73. The interpretations shown are based on (1) the slope of old erosion surfaces that may be tilted, as indicated by local cappings of erosional remnants of Pleistocene formations that dip down slope, (2) the amount of uplift and dissection of Pleistocene formations, together with dips greater than the initial dip of these units, and (3) the variations of thickness of alluvial fill in valley areas, as determined from logs of drill holes.

An attempt was made in figure 73 to distinguish areas undergoing active uplift from those that are stable or being depressed; the probable cause of the stresses is also indicated. Nearly all the major faults shown affect Quaternary formations and were therefore active during that period. It may be noted that almost all the active uplift is along or adjacent to major faults, especially the San Andreas and Garlock fault zones.

\section{SUMMARY OF GEOLOGIC HISTORY}

Precambrian(?) times.-The region subsided during the Precambrian(?) and probably was submerged under the sea. Great thicknesses of sediments and pos- 


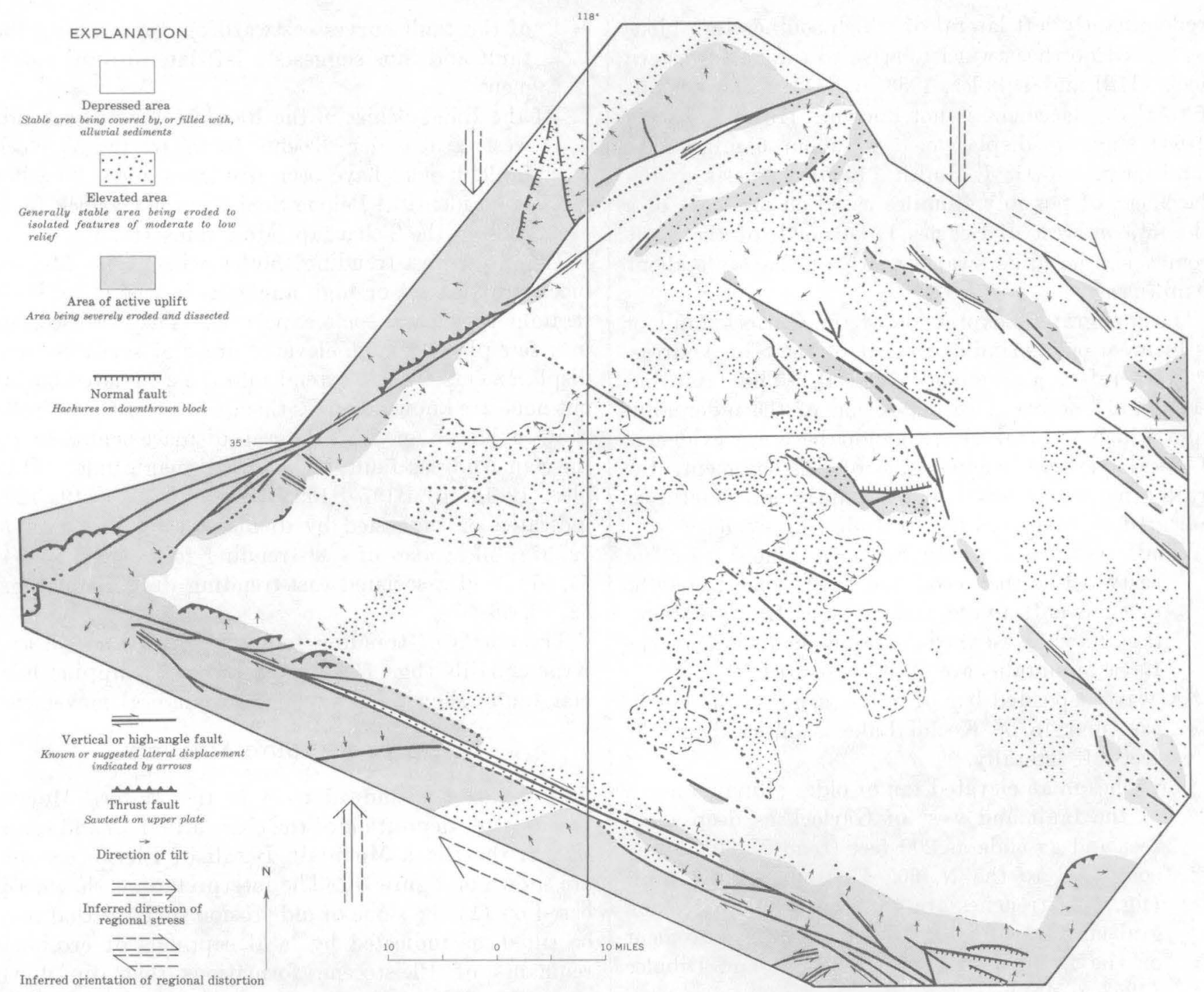

FIGURE 73.-Tectonic map of western Mojave Desert, showing major faults and inferred late Quaternary deformation.

sibly some pyroclastic material accumulated and then became deeply buried. These deposits were later deformed and recrystallized to form schistose and gneissic rocks. The region finally emerged from the sea and erosion began.

Paleozoic Era.-Again during the Paleozoic, the region was submerged under a widespread sea and thick deposits accumulated (Garlock, Bean Canyon, and Oro Grande Formations, or their equivalents). In the eastern part of the region, there was local diastrophism and erosion, then more deposition of sediments (Fairview Valley Formation).

Mesozoic Era.-During Mesozoic time, both intrusion and extrusion of metavolcanic rocks occurred. Paleozoic rocks were severely deformed and recrystal- lized, and the entire region was intruded by a quartz monzonite batholith, elevated into mountainous terrain, then deeply eroded.

Cenozoic Era.-In Tertiary time some parts of the region were elevated and eroded, but other parts were submerged. The deeply eroded pre-Tertiary surface in the submerged parts was buried under detritus from the elevated parts and by volcanic material. Many volcanic eruptions took place in Oligocene (?) and early and middle Miocene times. Widespread torrential downpours during late Miocene time caused severe erosion and correspondingly rapid deposition. Again in late Miocene and Pliocene times, there were more local volcanic eruptions. Tertiary paleogeography was presumably about like that shown on figures $74-77$. 


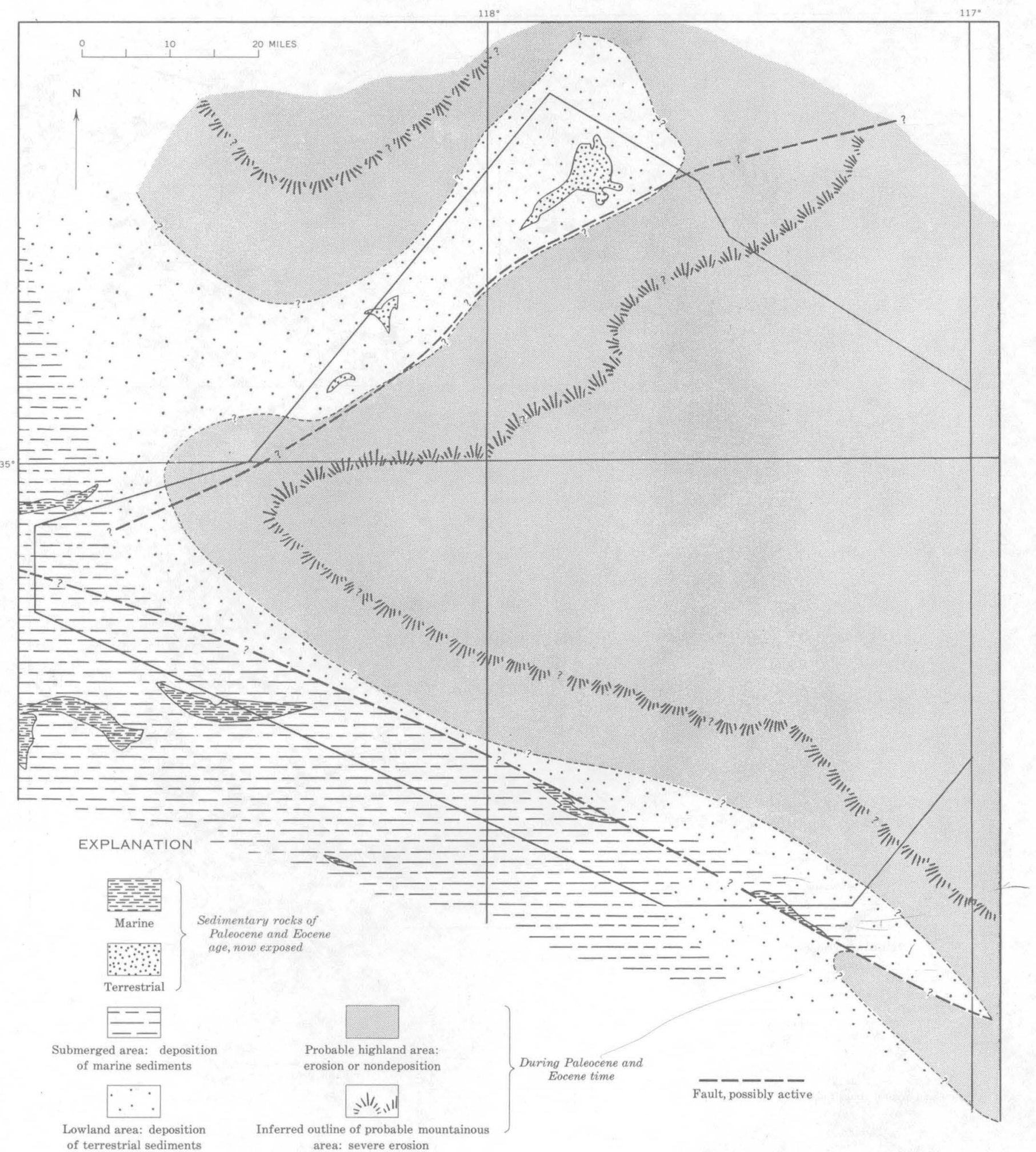

Figure 74.-Paleogeographic map of western Mojave Desert region-Eocene and Paleocene times. Outline of mapped area of plate 1 indicated by light solid line. 


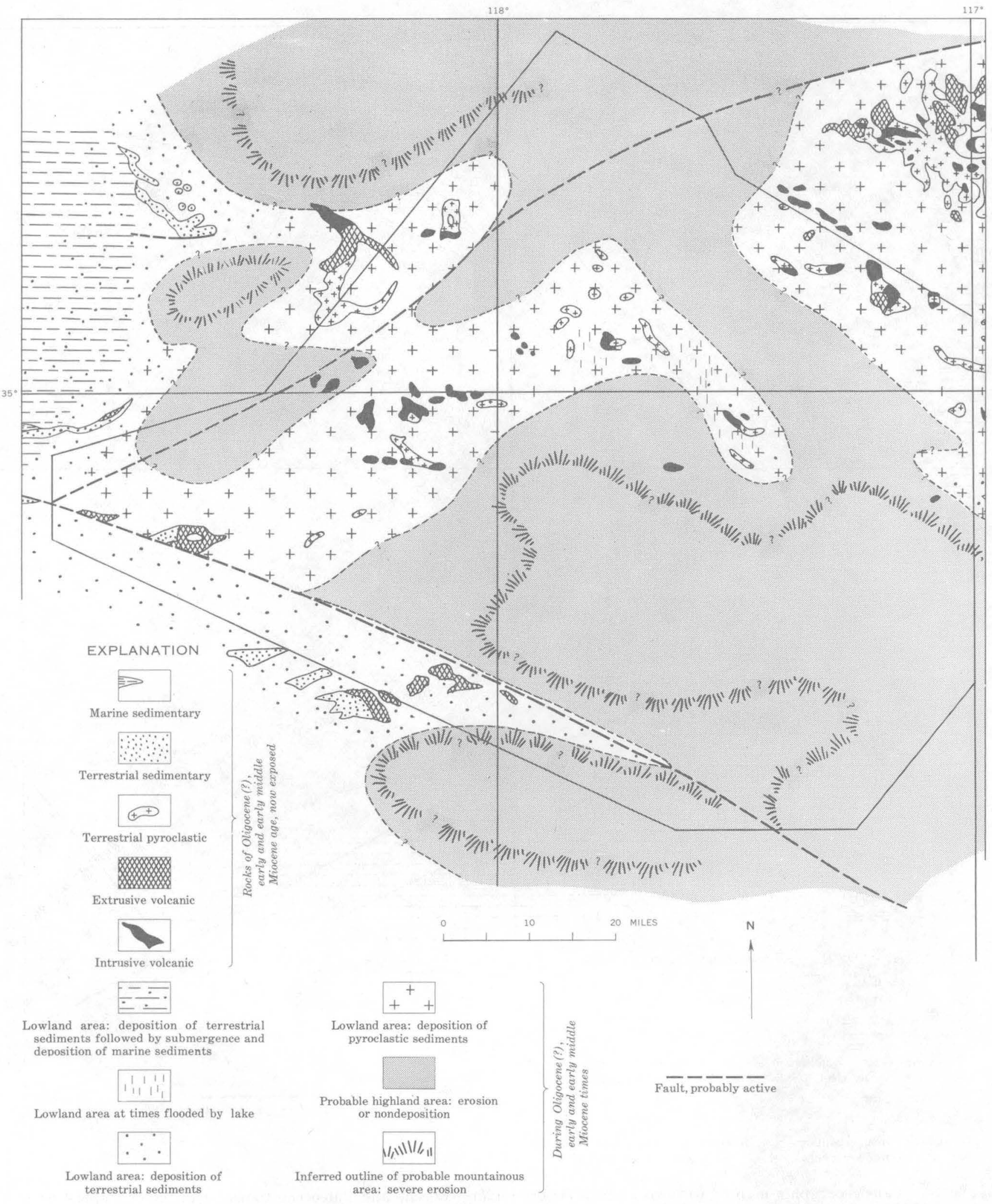

Figure 75.-Paleogeographic map of western Mojave Desert region-Oligocene(?) and early and early middle Miocene times. 


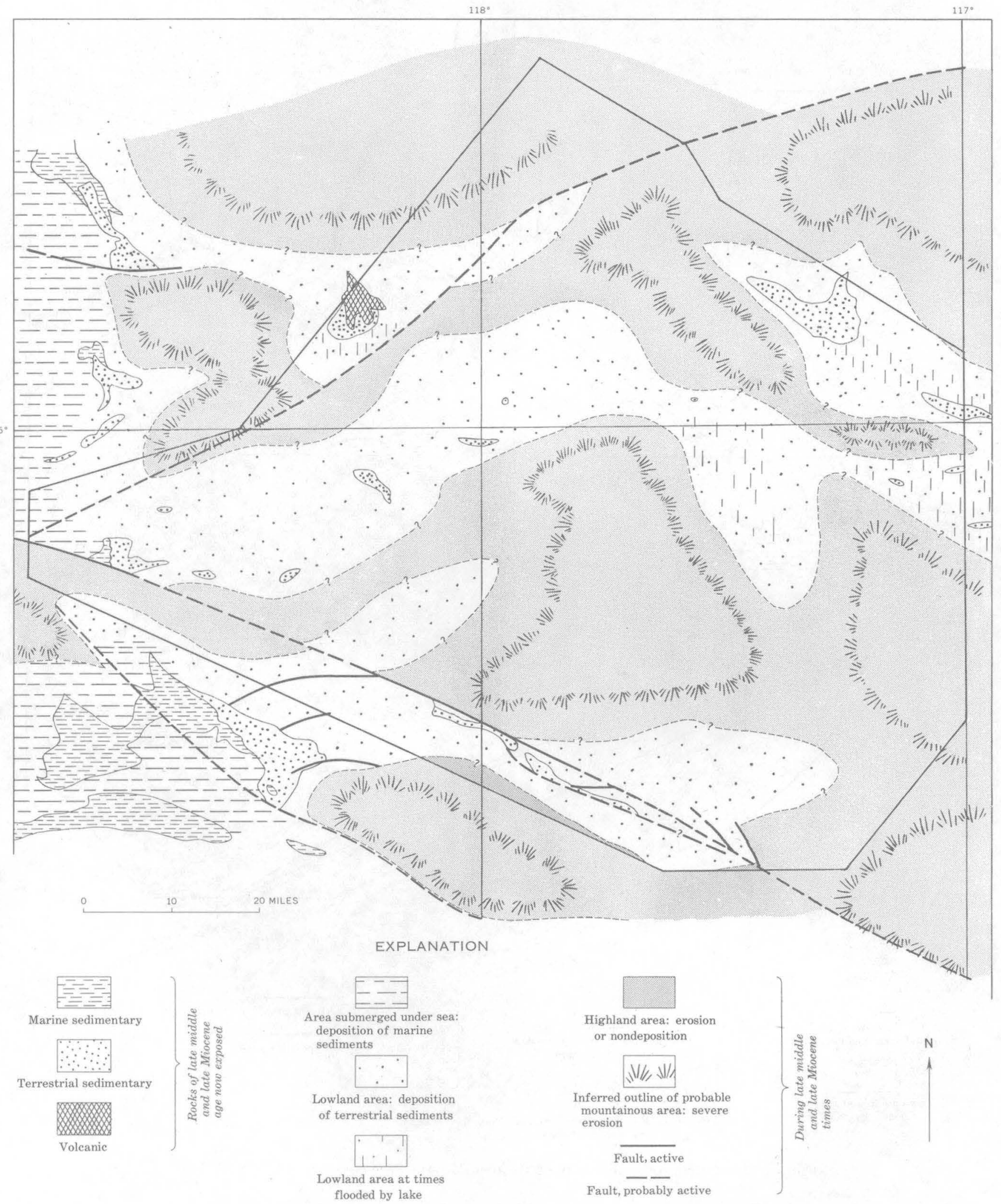

FIGURE 76.-Paleogeographic map of western Mojave Desert region-late middle and late Miocene times. 


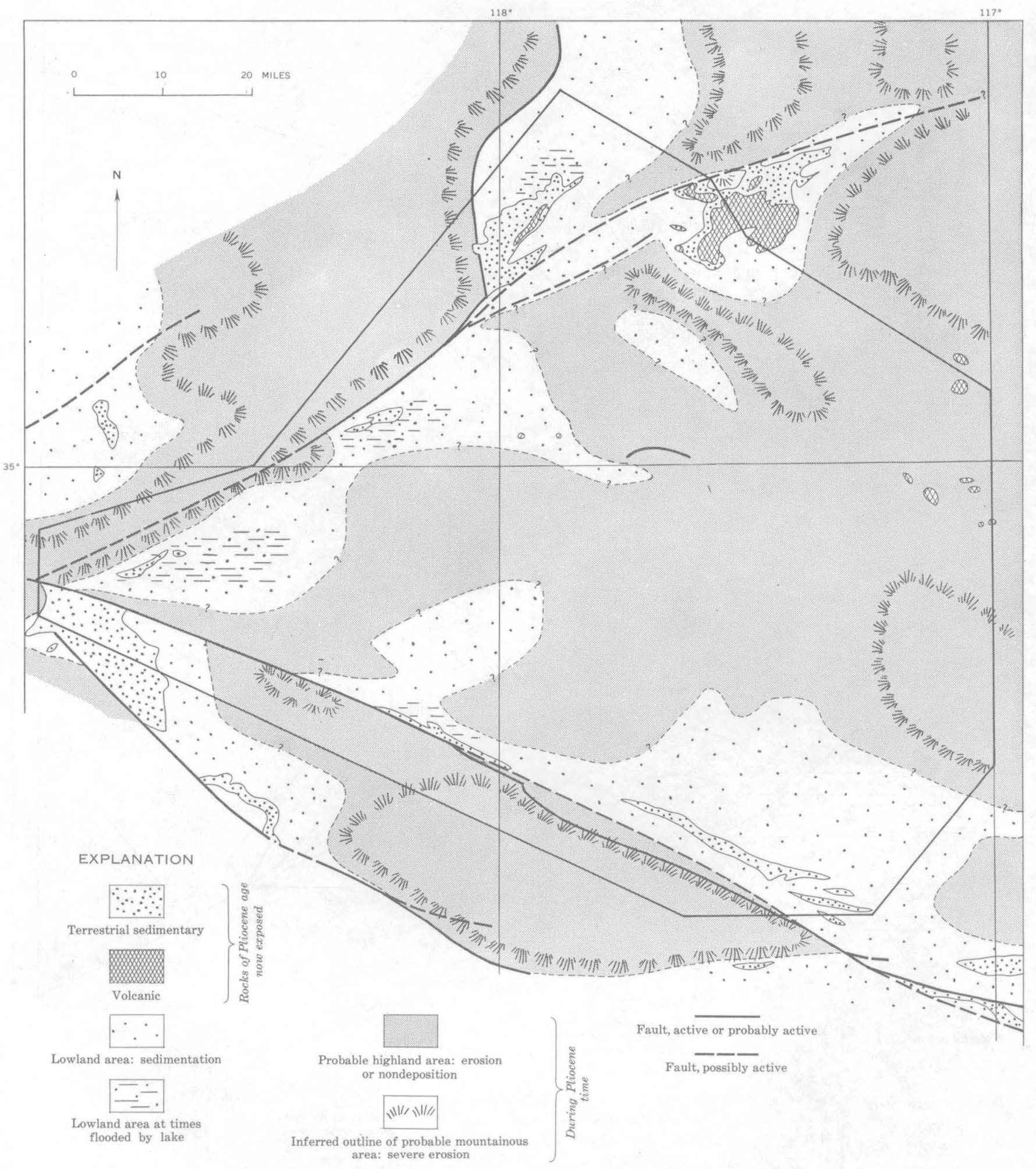

Figure 77.-Paleogeographic map of western Mojave Desert region-Pliocene time. 
During Quaternary time, deformation took place over most of the region (fig. 78). The San Andreas and Garlock fault zones were very active, the greatest uplift and most rapid erosion being in areas adjacent to these fault zones. The physiography of the region during the Pleistocene Epoch was about like that shown on figures 79-81. The present-day physiography and drainage are shown on plates 1 and 2 .

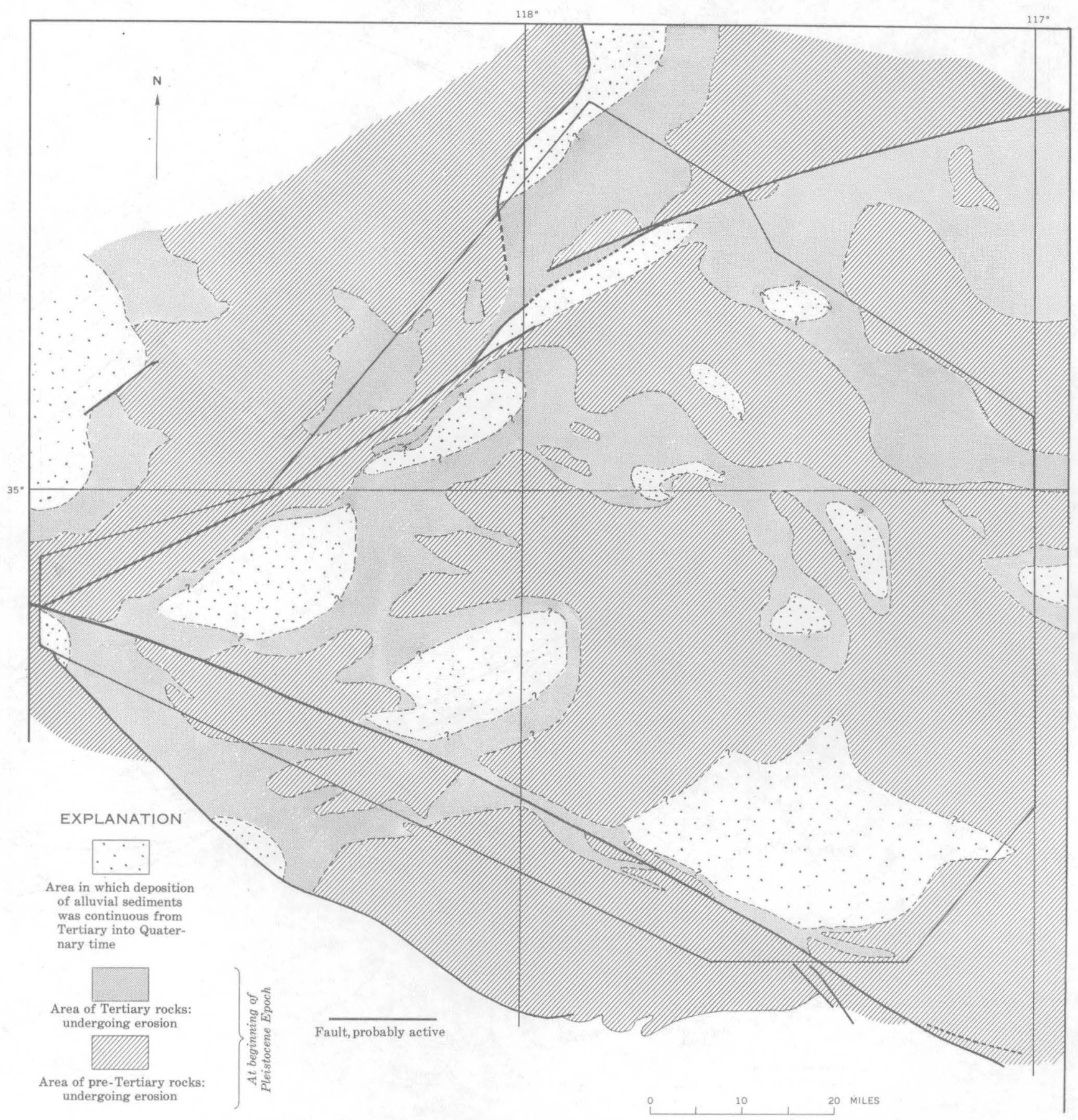

Figure 78.-Paleogeographic map of western Mojave Desert region-beginning of Pleistocene time. 


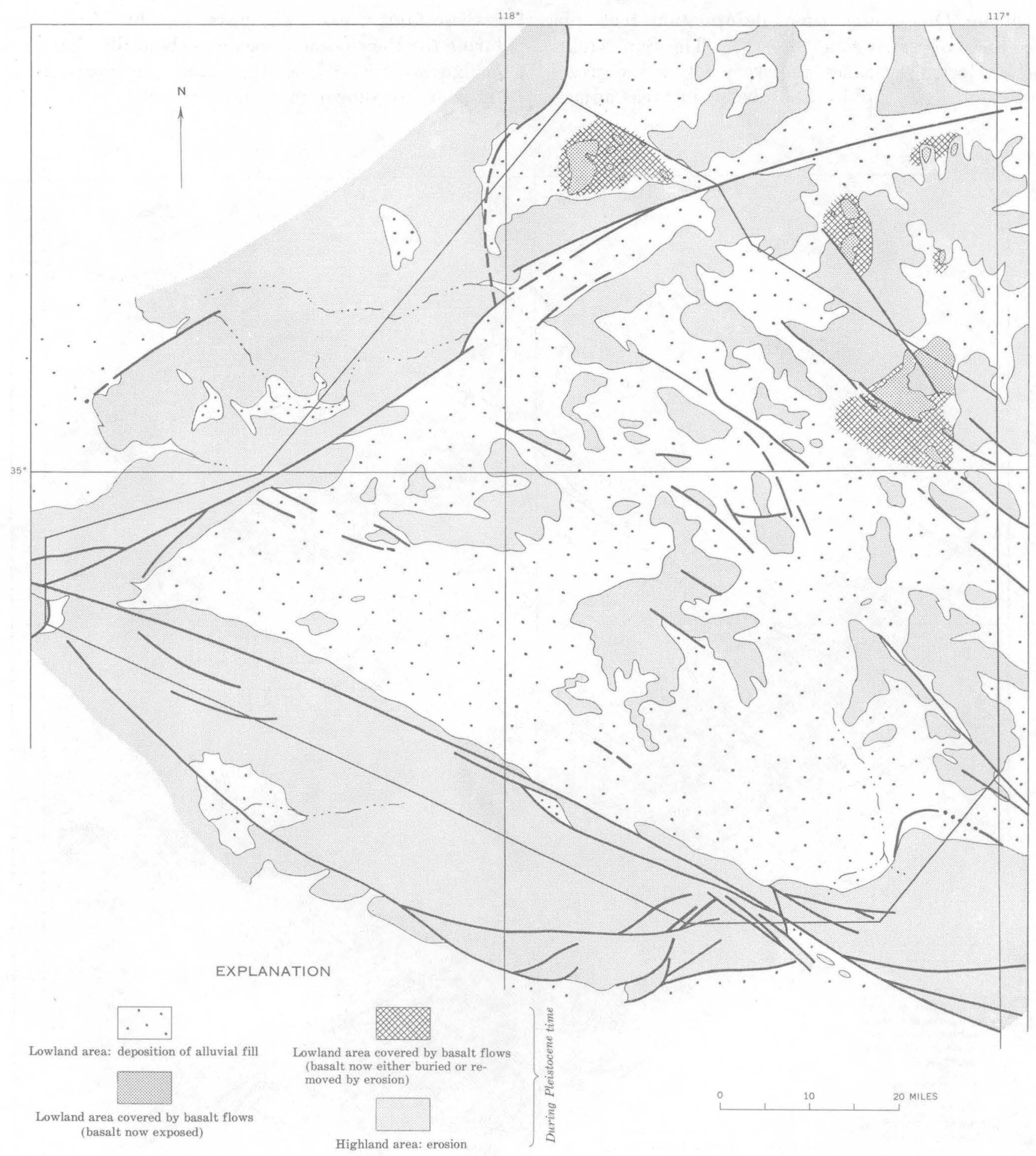

Fault, probably active

Figure 79.-Paleogeographic map of western Mojave Desert region-Pleistocene time. 


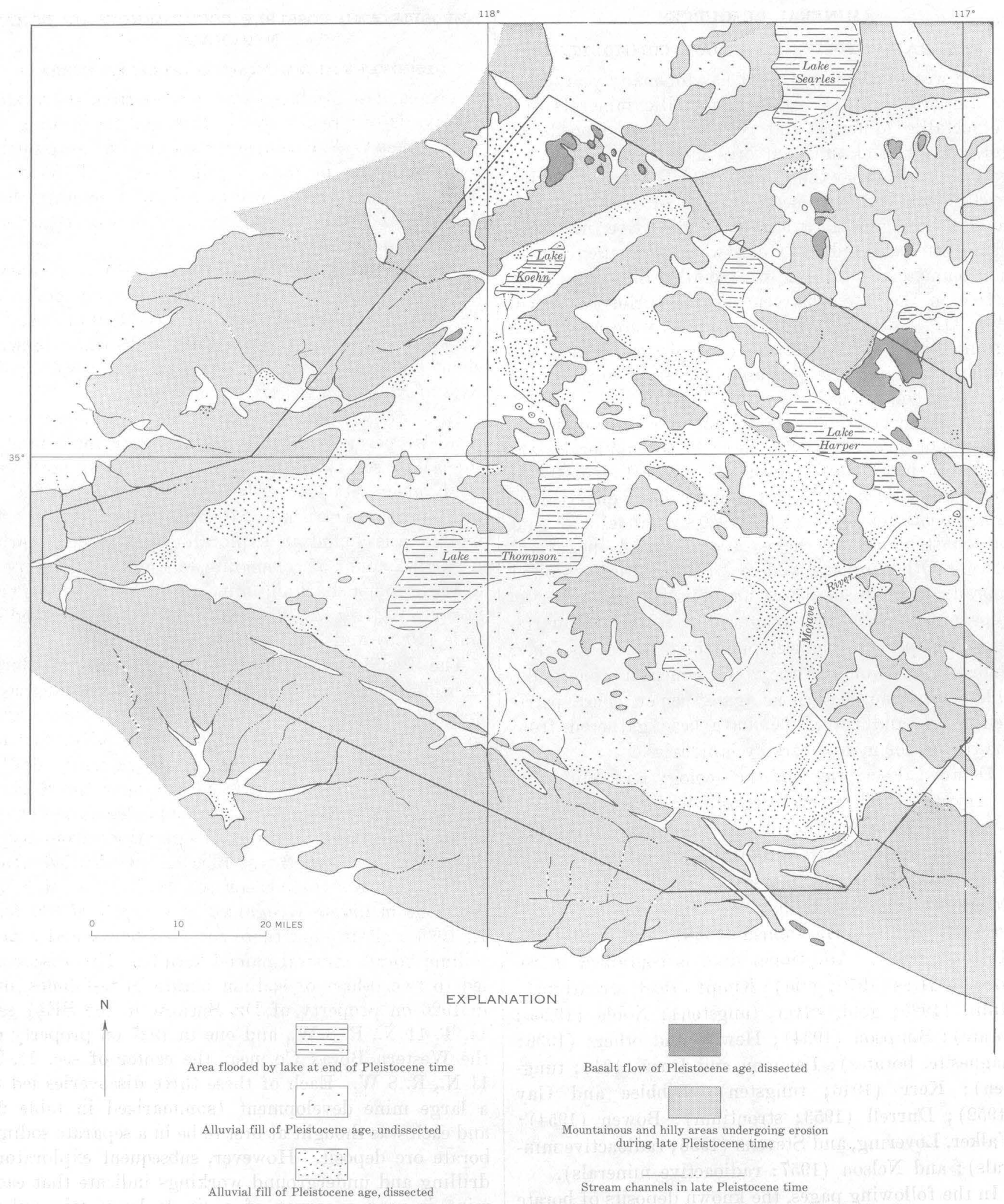

FIgURE 80.-Paleogeographic map of western Mojave Desert region at end of Pleistocene time. 


\section{MINERAL RESOURCES}

MINERAL DEPOSITS AND ROCK COMMODITIES

The western Mojave Desert has for many years been an important source of both metallic minerals and nonmetallic minerals and rocks. Large deposits of gold, silver, and tungsten ores have been mined for years, mostly from the Mojave and Rand mining districts. Small occurrences of ores of tin, lead-zinc, copper, manganèse, iron, and radioactive materials have been exploited but yields were subcommercial or noncommercial. Mining of metallic ores was most active in the late 19th century and prior to World War II. After that, very few mines were active; all are now idle, mainly because of depletion of more accessible higher grade ores and because of unfavorable economic conditions.

Limestone and dolomite suitable for cement manufacture or granules, as well as borate minerals, are the most important nonmetallic mineral deposits in the western Mojave Desert, having been quarried or mined continuously since the 1920's. Gravel and sand for construction use have been quarried in several places. Other mineral and rock commodities exploited sporadically in a small way are deposits of salt, barite, gypsum, strontianite, magnesite, feldspar, quartz, quartzite, perlite, pumice, pumicite, clay rocks, clay, slabrock, and volcanic rock. Ornamental stones suitable for polishing, such as agate, jasper, chert, petrified wood, and travertine, have been gathered from the region for many years by lapidaries.

Detailed descriptions of the geology and mining or quarrying of the mineral deposits and rock commodities of the western Mojave Desert are given in the following county reports published by the California Division of Mines and Geology : Tucker, Sampson, and Oakeshott (1949); Gay and Hoffman (1954); Wright, Stewart, Gay, and Hazenbush (1953); and Troxel and Morton (1962). Additional data is contained in reports by Hess (1910; gold); Knopf (1918; strontium); Hulin (1925; gold, silver, tungsten); Noble (1926a; borate) ; Simpson (1934); Hewett and others (1936; magnesite, borates); Lemmon and Dorr (1940; tungsten); Kerr (1946; tungsten); Dibblee and Gay (1952) ; Durrell (1953; strontium); Bowen (1954); Walker, Lovering, and Stevens (1956; radioactive minerals); and Nelson (1957; radioactive minerals).

In the following pages, the known deposits of borate minerals are described and evaluation is made of the region for possible undiscovered deposits of these minerals, as well as for petroleum and gas; ground-water conditions are briefly outlined.
DEPOSITS AND POSSIBLE OCCURRENCES OF BORATE MINERALS

DISCOVERY AND MINING OF BORATE MINERAIS

The earliest production of borates from the western Mojave Desert region was in 1898 and the ensuing few years, when C. A. Koehn gathered ulexite "cotton balls" by hand from the plowed soil in sec. 8, T. 30 S., R. $38 \mathrm{E}$., on the southwestern margin of Koehn dry lake. A total of three carloads of ulexite was reportedly shipped to San Francisco.

Just beyond the borders of the mapped area, colemanite was mined occasionally from severely deformed Tertiary lacustrine shale in the Calico Mountains and in Lockwood Valley 11 miles west of Gorman between about 1890 and 1915, and in Tick Canyon 13 miles west of Soledad Pass after about 1907.

In a well drilled for water in 1913, on the homestead property of Dr. O. Suckow near the center of the NW.1/4, sec. 22 , T. 11 N., R. 8 W., 8 miles northwest of Kramer Station, a borate mineral identified as colemanite was struck at 370 feet. Subsequently colemanite was found in exploratory test holes nearby. A small amount of colemanite was mined and shipped in 1924 from a shaft and mine on the Suckow property in the NE $1 / 4$, sec. 22, T. 11 N., R. 8 W. as described by Gale (1926) and Noble (1926a), (see table 2).

The Pacific Coast Borax Co., Division of Borax Consolidated, Ltd., of London, which was mining colemanite at Ryan, near Death Valley, acquired title to many claims in the Kramer district after the discovery of colemanite there, and subsequently drilled 41 test holes in the alluviated flat near the Suckow shaft. Most of these holes revealed colemanite but not enough to warrant transfer of operations from Ryan. Not until 1925, when test hole 42 was drilled about 300 feet south of the NE cor. sec. 24, T. 11 N., R. 8 W., was sodium borate recognized at a depth of 380 feet. In 1926 a shaft sunk there revealed borax and a new sodium borate mineral named kernite. This discovery led to two others of sodium borate in test holes, one in 1926 on property of Dr. Suckow in the SE1/4 sec. 14, T. 11 N., R. 8 W., and one in 1927 on property of the Western Borax Co. near the center of sec. 24, T. 11 N., R. 8 W. Each of these three discoveries led to a large mine development (summarized in table 2) and each was thought at first to be in a separate sodium borate ore deposit. However, subsequent exploratory drilling and underground workings indicate that each mine is near a corner of a single large triangularshaped tabular body of sodium borate ore.

The Kramer borate deposit is now the source of most of the boron compounds produced in the United States, and in fact the free world, because of the uniquely 
high concentration of sodium borate and shallow depth. The sodium borate mined is merely separated from the shale, refined, and marketed. Discovery of this deposit practically suspended mining of calcium borate because of the necessity and expense for conversion to sodium borate.

The annual tonnage of ore mined at Kramer was more than 150,000 short tons from 1934 to 1944 and more than 300,000 short tons from 1945 to 1958 . Underground mines of the Pacific Coast Borax Co. (Division of U.S. Borax and Chemical Corp. since 1956) yielded nearly all of this production. In 1957 a huge open pit was excavated at the west end and shallowest part of the ore body, and all operations converted to open pit mining. Ore from this open pit, now known as the Boron mine, is treated at an adjoining concentrator refinery completed in 1959.

The discovery of the Kramer borate deposit resulted in the drilling of many exploratory test holes for several miles around the deposit. The locations and results of many of these are shown and described by Gale (1946, p. 371-376, pls. 51, 52) and summarized in table 3. These test holes served to determine the approximate limits of the borate deposit and showed that there are no separate, outlying deposits.

The increasing demands for borate minerals since World War II, and the foreseeable exhaustion of the Kramer borate deposit, possibly within the next 100 years, stimulated recent exploration for other deposits of these minerals in adjacent parts of the western Mojave Desert. In 1955 and 1957, four exploratory core holes were drilled for the U.S. Geological Survey near Kramer Junction (Four Corners) and one near Boron. The results of these core holes were described in detail by Dickey (1957) and Benda, Erd, and Smith (1960) and were summarized by W. C. Smith (1958, p. 26); they are listed in table 3. In addition, several test holes were drilled by private interests a few miles farther west, but these revealed no borate deposits.

U.S. Geological Survey holes, Four Corners 3 and 4 , penetrated minor laminae of calcium borate (colemanite) in shale, as did two earlier nearby test holes drilled for R. C. Phillips in 1948. Four Corners 5, still farther southeast (in SE1/4 sec. 30, T. 11 N., R. $6 \mathrm{~W}$., S.B.) resulted in the discovery of a small deposit of calcium borate. This discovery was followed in 1958-59 by the drilling for Kern County Land Co. of some 14 test holes in the east half of that section, together with 14 step-out holes (fig. 49 ; table 3 ), for the purpose of evaluating the reserve potential of this borate deposit. In that same year, four test holes were drilled in the area a few miles east of this deposit for the Kerr-McGee Oil Industries of Oklahoma, but these revealed no borates.

Many shallow test holes (to depths of about 500 feet) were also drilled in 1958 by the Sunray Mid-Continent Oil Co. on the alluviated flats adjacent to Koehn Lake; south of the Stonehouse Hills, near (old) Kramer; and 4 miles northwest of Kramer Junction, in that order. Three of seven core holes in the last-named locality, S1/2 sec. 13, T. 11 N., R. 7 W., revealed another small deposit of calcium borate.

This brief flurry of exploratory drilling for borate minerals has thus revealed the presence of two small low-grade deposits of calcium borate about 2 miles apart, both concealed under the alluviated flat north of Kramer Junction or Four Corners and 5-7 miles east of the big Kramer borate deposit. That 11/2 miles north of Kramer Junction is hereafter referred to as the East Kramer section 30 borate deposit, and that 4 miles northwest of Kramer Junction as the East Kramer section 13 borate deposit (fig. 49).

Exploratory test holes drilled in the western Mojave Desert mainly for borate minerals and on which data are available are summarized in table 3.

\section{GEOLOGY OF KNOWN BORATE DEPOSTTS}

All the borate minerals now mined from the western Mojave Desert are from the Kramer borate deposit near Boron. This deposit is described in detail by Gale (1946, p. 325-378, pls. 51, 52), described briefly by Tucker, Sampson, and Oakeshott (1949, p. 241-244); Ver Planck (1957, p. 90-94; in Troxel and Morton, 1962, p. 39-40, 61-68). The following description is summarized from these sources, supplemented by observations in the mines by the writer. Data on individual mines are listed in table 2 , and those on test holes drilled for borates and other saline minerals are listed in table 3 . The borate minerals of the Kramer district are described by Schaller (1930, p. 137-170). In the mine area there is a clay shale unit that is about 320 feet thick and is divisible into three parts (Gale, 1946, p. 340-346). In descending order these are (1) so-called hanging-wall shale, 30-50 feet thick, containing minor scattered borates, (2) middle or bluish-gray shale, 200-250 feet thick, containing the sodium borate deposit (fig. 47) known as the crystal body or ore body, and (3) a footwall shale, 25-30 feet thick, containing minor borates.

In the peripheral zone (fig. 46), which contains calcium borates, the three divisions of the clay shale unit are not certainly recognizable.

The sodium borate ore body is composed of seminodular layers, lenses, layers of nodules or crystals, crystalline masses, and veinlets of borate minerals in 
clay shale. The layers range from less than a quarter of an inch to several inches thick. The percentage of borates in the shale ranges from less than 1 percent to nearly 100 percent.

The sodium borates consist mainly of two mineralsnative borax (or tincal), $\mathrm{Na}_{2} \mathrm{~B}_{4} \mathrm{O}_{7} \cdot 10 \mathrm{H}_{2} \mathrm{O}$; and kernite (or rasorite), $\mathrm{Na}_{2} \mathrm{~B}_{4} \mathrm{O}_{7} \cdot 4 \mathrm{H}_{2} \mathrm{O}$. The borax is clear, granular, noncleavable, icelike, and commonly forms discrete, subhedral to euhedral crystals $1 / 4-1$ inch in diameter. The kernite is olear, cleavable in two directions to splintery fragments, and commonly forms very coarsely crystalline masses. The borax occurs in the shallower part of the ore body, the kernite in the deeper part, regardless of stratigraphic position. On exposure to air, even in the mines, borax soon dehydrates to tincalconite, $\mathrm{Na}_{2} \mathrm{~B}_{4} \mathrm{O}_{7} \cdot 5 \mathrm{H}_{2} \mathrm{O}$, a white powdery substance. Kernite also alters to tincalconite, but very slowly and indirectly through hydration to borax (Muessig and Allen, 1957, p. 699-701). Ulexite, $\mathrm{NaCaB}_{5} \mathrm{O}_{9} \cdot 6 \mathrm{H}_{2} \mathrm{O}$, a white fibrous mineral, occurs in comparatively minor amounts as thin fibrous layers and veinlets.

The hanging wall and footwall shales contain no borax or kernite, but both contain scattered thin layers, veinlets, and nodules of ulexite. A few nodular lenses of colemanite also occur in the hanging wall shale.

Other minerals occurring commonly but in only very small quantities in the $\mathrm{Kramer}$ borate deposit are probertite ("kramerite"), $\mathrm{NaCaB}_{5} \mathrm{O}_{9} \cdot 5 \mathrm{H}_{2} \mathrm{O}$, and searlesite, $\mathrm{NaB}\left(\mathrm{SiO}_{3}\right)_{2} \cdot \mathrm{H}_{2} \mathrm{O}$, both common in the ore body; howlite, $\mathrm{Ca}_{2} \mathrm{SiB}_{5} \mathrm{O}_{9}(\mathrm{OH})_{5}$, common only in the footwall shale; sassolite, $\mathrm{H}_{3} \mathrm{BO}_{3}$; "inderite", $\mathrm{Mg}_{2} \mathrm{~B}_{6} \mathrm{O}_{11}$ " $15 \mathrm{H}_{2} \mathrm{O}$; "lesserite", $\mathrm{Mg}_{2} \mathrm{~B}_{6} \mathrm{O}_{11} \cdot 13 \mathrm{H}_{2} \mathrm{O}$; inyoite, $\mathrm{Ca}_{2} \mathrm{~B}_{6}$ $\mathrm{O}_{11} \cdot 13 \mathrm{H}_{2}()$; tunellite, $\mathrm{SrO}_{3} \mathrm{~B}_{2} \mathrm{O}_{3} \cdot 4 \mathrm{H}_{2} \mathrm{O}$; calcite; dolomite; the zeolites analcime and clinoptilolite (in tuff layers); the arsenic sulfides realgar and orpiment; stibnite, $\mathrm{Sb}_{2} \mathrm{~S}_{3}$; gerstleyite, $(\mathrm{Na}, \mathrm{Li})_{4} \mathrm{As}_{2} \mathrm{Sb}_{8} \mathrm{~S}_{17} \cdot 6 \mathrm{H}_{2} \mathrm{O}$; and rare iron sulfides (R. C. Erd, oral commun., 1961).

The borate minerals in the shale of the peripheral zone around the sodium borate ore body are mainly ulexite in the form of fibrous nodules, layers, and veinlets, and colemanite, $\mathrm{Ca}_{2} \mathrm{~B}_{6} \mathrm{O}_{11} \cdot 5 \mathrm{H}_{2} \mathrm{O}$, as strata or lenses of coarse cleavable masses. These borate minerals are locally abundant, but in most places are scattered within the shale.

Saline minerals such as chlorides and carbonates of sodium and potassium, commonly present in other lacustrine clays of the Mojave Desert region, are notably absent in the Kramer borate deposit.

The sodium borate ore body terminates rather abruptly at its margins, in a manner that is not yet clearly understood. Gale $(1946$, p. 343$)$ assumes that the ore body lenses out and that the stratigraphically equivalent shale beyond its borders contains the calcium borates of the peripheral zone. However, discordant relationships between the ore body and the overlying hanging-wall shale as exposed in the open pit and in the Mudd (Western Borax) mine led W. C. Smith $(1960$, p. 113$)$ to believe that the ore body is overlain unconformably by the hanging-wall shale. But in a talk (presented before Am. Inst. Mining Metall. Engineers, San Francisco, 1959) after submittal of his paper for publication, Smith attributed the angular discordance to downward settling of the hanging-wall shale as the marginal part of the underlying ore body was dissolved out by ground water. Evidence of this condition is the continuation of thin marker beds such as sandstone or tuff from the ore body across the discordant contact directly into jumbled clay that forms the adjacent part of the hangingwall shale. The jumbled clay contains nodules of ulexite and colemanite, and both apparently replace dissolved-out borax.

As mapped by Gale (1946, pl. 52), the shale that contains the borate minerals of the Kramer district dips gently into the axis of a syncline that passes eastward through the southern part of the ore body (fig. 46). The ore body terminates southward against a fault and is transected by several northwest-trending faults (fig. 46). Minor subsidiary folds are structural irregularities.

Depths from the surface to the top of the ore body range from about 140 feet in the northern and western parts to about 1,100 feet in the southern part. The ore body of water-soluble sodium borate minerals is apparently protected from solution by ground water by the enclosing envelope of impervious shale, for the mines within it are dry and the ore is unleached except along some faults and at its margins.

The two East Kramer calcium borate deposits of the Kramer Junction area are near the middle of a clay shale unit (upper part of Tropico Group, fig. 49). It is similar to and presumably correlative with part or all of the 320-foot-thick clay shale unit that contains the borate minerals of the big Kramer deposit. In the Kramer Junction area the shale unit rests on hard granitic conglomerate (lower part of Tropico Group) and grades upward through arkosic sandstone into coarse granitic conglomerate (upper part of Tropico Group). These formations are warped into a broad syncline, the axis of which trends east between the two calcium borate deposits (fig. 48 , section $B-B^{\prime}$ ).

In both the East Kramer deposits the borate minerals are almost all colemanite. It occurs as thin layers of white crystalline material intercalated in gray clay shale. Individual layers range in thickness from lami- 
nae to as much as 4 inches in the section 30 deposit to 2 inches in the section 13 deposit. Other minerals present in small amounts in the shale with colemanite in the section 30 deposit are veatchite, $\mathrm{SrO} \cdot 3 \mathrm{~B}_{2} \mathrm{O}_{3}$; calcite, dolomite, analcime, heulandite; the arsenic sulfides realgar and orpiment; and a rare iron sulfide (Benda, Erd, and Smith, 1960, p. 330).

The East Kramer section 30 borate deposit, mostly in the E1/2 sec. 30, T. 11 N., R. 6 W., 2 miles north of Kramer Junction, underlies about 200 acres (fig. 49). The shale that contains the colemanite is gently folded with dips of less than $15^{\circ}$, with an average of $4^{\circ}$; minimum depth to the top of the colemanite zone is 780 feet; two zones of colemanite shale having maximum thicknesses of 100 and 90 feet are reported (Griswold, 1959 ; table 3 ).

The East Kramer section 13 borate deposit was revealed in three adjacent core holes near the middle of the S1/2 sec. 13, T. 11 N., R. 7 W. Four other core holes drilled to the west and north within this half section failed to penetrate borates in the shale, a condition that has been attributed to possible faulting. Depths of these seven core holes range from 538 to 575 feet. The clay shale unit penetrated below the alluvium presumably dips southward from $20^{\circ}$ in the most southerly holes to $55^{\circ}$ in the most northerly. The depth to the top of the colemanite zone ranges from 458 to 538 feet in the three holes that penetrated it; from 40 to 98 feet of the zone was penetrated, but the base was not reached. Average grade of the zone penetrated is about 3.7 percent $\mathrm{B}_{2} \mathrm{O}_{3}{ }^{2}$

\section{PROBABLe GeNESIS}

As postulated by Gale (1946, p. 376-377), the borate minerals of the Kramer district accumulated in a large desert lake in which clay of the shale unit of the Tropico Group (upper part) were deposited. The boron presumably came from the earth's interior in solution, possibly in the form of boric acid, in thermal waters that flowed from hot springs nearby. These springs presumably issued after eruption of the Saddleback Basalt, possibly from or near fissures or vents through which the lava was erupted. The other unusual substances such as strontium, arsenic sulfides, and other rare sulfides present in the borate deposits were almost certainly brought up in hot-spring waters. The sodium and calcium ions that combined with the boron were either present in the hot-spring waters also, or else were contained in the lake waters into which the boron-rich hot-spring waters flowed.

\footnotetext{
${ }^{2}$ R. N. Maynard, geologist, Sunray Mid-Continent Oil Co. (oral commun., 1961); permission to publish data presented in foregoing paragraph granted by Sunray Mid-Continent Oll Co. (written commun. to W. C. Smith, June 20, 1960).
}

One theory for the origin of the deposit is: The borates presumably precipitated as the thermal waters entered the lake and cooled, or as the lake waters evaporated and became saturated with boron. If the calcium borates, such as ulexite and possibly colemanite, are primary, they may have been the first borates to precipitate because they are the least soluble. Presumably they precipitated along the receding margin of the lake. The sodium borate precipitated, probably as borax, when its concentration in the water reached the saturation point as the lake receded still farther, probably to or near the original margin of the ore body. It is possible that the lake may have evaporated completely, but this is unlikely because of the absence of common evaporites such as carbonates and chlorides of sodium. Deposition of the ore body was followed by transgression of the lake waters when clay and some calcium borate, if primary, were again deposited.

The colemanite of the East Kramer deposit precipitated either as colemanite or as some other borate, presumably in the eastern part of the lake in which the borates of the Kramer deposit precipitated, if not in a separate lake.

It is believed that kernite formed from dehydration of borax (Gale, 1946, p. 377; Schaller, 1930, p. 166$167)$, as the result of heat and pressure, possibly from burial at depth. The alteration is strongly suggested by the position of the kernite only in the deeper part of the ore body and borax in the shallow part, regardless of stratigraphic position.

Colemanite may have formed by alteration of ulexite (Gale, 1946, p. 377; Schaller, 1930, p. 138) with which it is commonly associated, presumably by replacement of sodium by calcium and loss of water by hydration. Colemanite may even replace borax, as suggested previously, along the margin of the ore body.

\section{RESER VES}

Detailed data on the underground areal extent, thickness, grade, and tonnage reserves of the sodium borate ore body and of the calcium borate peripheral deposit are not available. The sodium borate ore body underlies about 500 acres, is as much as 226 feet thick, and averages about 75 feet thick; it contains about 92,250 ,000 short tons of borax (Gale, 1946, p. 344). Huttl $(1958$, p. 102) estimated that the sodium borate deposit contains more than 80 million tons of ore averaging about 25 percent boric oxide $\left(\mathrm{B}_{2} \mathrm{O}_{3}\right)$.

The peripheral zone of calcium borate ore is of generally low grade as compared to that of the sodium borate ore and is presumably thinner, but it underlies a much greater area (fig. 46), as shown by Gale (1946, pl. 51). Therefore, a large tonnage of colemanite and 
ulexite ore makes up a major part of the Kramer borate deposit.

The areal extent and thickness of the East Kramer colemanite (section 30) deposit have been tested by core holes drilled for the Kern County Land Co. This deposit extends under an area of $200-300$ acres, and is estimated (Griswold, 1959) to contain approximately 40 million tons of ore having an average grade of 14 percent $\mathrm{B}_{2} \mathrm{O}_{3}$.

\section{POSSIBLE OCCURRENCES OF OTHER BORATE} DEPOSITS AND AREAS FA VORABLE TO PROSPECT

In the Mojave Desert and adjacent regions, known borate deposits are found in lacustrine clay shale of Oligocene or early Miocene to Pliocene age that overlies or contains volcanic flows, generally of basaltic composition. Areas underlain by sequences of this type are therefore considered favorable for the occurrence of borate deposits. However, borate deposits occur or could occur in such sequences only if boronrich hot springs of volcanic origin issued nearby at the time the lake beds were accumulating within the drainage area and if the lake in which these beds accumulated and into which the boron-rich waters flowed evaporated enough to concentrate the borate solutions and precipitate them.

Within the western Mojave Desert region the Kramer and East Kramer borate deposits are the only ones found. However, it is remotely possibly that one or more borate deposits of economic value may be hidden in lacustrine shale within basins filled with Cenozoic terrestrial sediments (fig. 71). Such borate deposits can be revealed only by exploratory drilling.

Some subsurface information in the sedimentary basins within the western Mojave Desert is available from test wells drilled for minerals or petroleum (fig. 71 ; tables 3,4$)$. With the exception of holes drilled into the Kramer and East Kramer borate deposits, none of these test holes penetrated borate minerals or other salines. The following evaluation of the individual sedimentary basins with regard to the possibility of borate deposits is based on geologic environment and results of test holes:

1. Kramer basin : most favorable; Tropico Group contains lacustrine shale and basalt flows; shale in upper part contains Kramer and East Kramer borate deposits in western and central parts, respectively, of basin; other parts of basin partly tested, no borates found.

2. Fremont basin: probably unfavorable; sedimentary formation, if present, below older alluvium untested.
3. Barstow basin : favorable; Barstow Formation contains lacustrine shale and at least one basalt flow (formation contains colemanite deposits in Calico Mountains to east) ; but four test holes in Harper Valley revealed no borates.

4. Valley of Cuddeback Lake: probably unfavorable; no lake beds or basalt flows; untested.

5. Koehn basin: part northeast of Koehn Lake possibly lavorable, may contain lacustrine shale; Pliocene formation near Summit Diggings contains basalt flow and some shale, untested; ulexite "cotton balls" on surface of southwest margin of Koehn Lake favorable indication of borates either below surface or in unexposed Tertiary sediments within drainage area; part southwest of Koehn Lake probably unfavorable; four test holes (for oil) penetrated mostly sandy sediments.

6. Ricardo basin: favorable; Ricardo Formation contains lacustrine sediments and basalt flows.

7. Tehachapi basin : unfavorable; Bopesta Formation, nearly all sandstone, exposed.

8. Mojave basin: probably unfavorable; some lacustrine clay in Horned Toad Formation but no basalt flows; tested by two shallow holes.

9. West Antelope basin: probably unfavorable; Meeke Mine Formation contains lacustrine beds but no volcanic rocks; Miocene formations may contain some lacustrine beds but volcanic rocks mostly rhyolitic; several test holes penetrated mostly sandy sediments.

10. East Antelope basin: unfavorable; no volcanic rocks; two test holes penetrated mostly sandy sediments.

11. Cajon basin: unfavorable; no volcanic rocks; three test holes showed mostly sandy sediments down to basement complex.

\section{PETROLEUM AND GAS}

Many exploratory test wells have been drilled for petroleum in the western Mojave Desert since about 1900. All were abandoned after drilled. Although rumors circulate that some showings of petroleum were found, and one well is said to have flowed, no clear evidence is known that any test found even showings. The available data on these exploratory wells are summarized in table 4. Most of the test wells have yielded only fragmentary reliable subsurface geologic data because most were drilled without the supervision of a professional geologist and few or no cores were taken.

It is very unlikely that petroleum in commercial quantities exists in the western Mojave Desert region. Marine formations of Paleozoic(?) age are too severely 
metamorphosed and too widely intruded by plutonic rocks to contain or act as a source for oil and gas, and the thick Cenozoic sequences that fill the large sedimentary basins of the desert region contain no known marine source beds. There are no seeps of oil or gas to indicate the presence of these hydrocarbons underground.

It is remotely possible that the marine shale of the San Francisquito Formation was a source of gas or oil, but cap rocks and suitable closed structures in which such fluids could be trapped are not known.

It is also remotely possible that marine shale of the Quail Lake Formation at the west end of Antelope Valley was a source of some gas, if not petroleum, which could have migrated eastward into the terrestrial Oso Canyon Formation of West Antelope Basin (fig. 71). If so, the gas could have been entrapped in a closed structure, such as the Sand Hills anticline (pl. 1 ; fig. 69), that is if the Oso Canyon Formation or the overlying Meeke Mine Formation extends this far east and if possible reservoir sands are overlain by an impervious shale cap rock. No shale is recorded in the logs of several old test wells nearby, although the Meeke Mine Formation exposed 10-15 miles west contains lacustrine shale.

\section{GROUND WATER}

The results of detailed studies of water-well data and ground-water occurrence are available in the following reports: Johnson (1911), Thompson (1929), Page and Moyle (1960), Page, Moyle, and Dutcher (1960), Bader, Page, and Dutcher (1958), Dutcher (1959), Kunkel $(1956,1962)$, and Kunkel and others (1957); additional work is in progress. Therefore only the regional geologic aspects of the ground-water conditions, based on these references and on unpublished hydrologic studies, are discussed below.

\section{MOVEMENT OF GROUND WATFR}

Ground water is present at depths at which the rock units are saturated, either in fractures of the nonporous rocks or in interstices of the porous rocks. This water is derived almost entirely from precipitation. Most of the ground water of the western Mojave Desert is derived from the mountain slopes that drain into it because of the relatively heavy winter precipitation that falls on the bordering mountains as compared to the desert region. Consequently depths to the water table, or top of the ground-water saturation, vary with local topography and the seasons.

Runoff from the bordering mountains sinks rapidly into the porous alluvial detritus of the adjacent desert plain. Along the upper margin of the desert piedmont alluvial fans, depths to the water table are commonly several hundred feet. Downslope on the desert alluvium the water table slopes gradually downward at a gradient slightly less than the surface; depths to the water table therefore gradually decrease to a few tens of feet in the lower parts of the alluviated desert plain, or to only a few feet under the playas and under the Mojave River channel.

From these conditions it may be inferred that ground water derived from precipitation in the mountains gradually works down each of these alluviated desert plains to their lowest parts, where the excess water reaches the surface and evaporates. The alkaline condition of the soil around and on the playas is presumably in large part due to this evaporation of saturated nearsurface ground water.

In parts of the valley areas where ground water is pumped to the surface for use in irrigation during summer months from numerous wells, the water table is seasonally drawn down from a few feet to more than 100 feet below its natural position. However, it generally rises again during the winter or spring months when little or no ground water is pumped. This condition is further evidence of ground-water movement from the margins of the area.

EFFECT OF FAULTS ON GROUND-WATEAR MOVEMENT

Major faults appear to act as barriers to downslope movement of ground water, especially the San Andreas fault, as indicated by seeps and springs along many parts of it, particularly where it transects alluviated flood plains of canyons or alluvial slopes. The same is true of the Garlock fault in the Tehachapi Mountains. Willow Springs issue from the base of the Willow Springs fault scarp. In each place the ground water on the upslope side apparently backs up against the fault, which acts as an "underground dam," and the overflow reaches the surface to seep out as one or more springs. Along several other faults within the desert, such as the northwest extension of the Muroc fault, the water table may be several tens of feet higher on the upslope (southwest) side. There is no verified evidence to support the belief that major faults in the Mojave Desert act as conduits for lateral movement of ground water.

\section{GROUND WATER IN PRE-TERTIARY ROCKS}

The pre-Tertiary crystalline rocks are impervious and contain ground water only in fractures and joints. Generally these rocks yield only a few gallons of water per minute to wells. Only in places where such rocks are severely fractured, especially along or near major faults, do they yield as much as several tens of gallons per minute per well. Wells that penetrate major joints, 
fractures, or faults, in these rocks below the water table, locally obtain moderate yields. Areas of crystalline rocks within the alluviated desert plain form barriers to ground-water movement through the alluvial fill.

\section{GROUND WATER IN TERTTARY ROCKS}

Consolidated rocks of Tertiary age are slightly or moderately permeable. Volcanic rocks, hard indurated tuff, conglomerate, sandstone, shale, and carbonate rocks are generally impervious and contain water mostly in fractures as do the crystalline rocks. Friable sandstone and conglomerate are slightly to moderately permeable; rocks of this type yield a few gallons to several tens of gallons of water per minute to wells that penetrate below the water table. Areas of consolidated rocks of Tertiary age in the alluviated desert plain impede ground-water movement much as do the older crystalline rocks.

\section{GROUND WATER IN QUATHRNARY SFDIMENTS}

Alluvial sediments of Quaternary age that fill the Mojave Desert plains are generally permeable and consequently form the main ground-water reservoirs where they are saturated below the water table. Clay, or sand and gravel having a clayey matrix, is generally impervious. Clean sand or gravel is highly permeable and yields moderate to large amounts of water to wells at depths below the water table. The largest yields, several hundred or, commonly, several thousand gallons per minute, are obtained from confined layers of sand or gravel that thin or lens out downslope into impervious clay near the lowest parts of the large undrained valleys-for example, near the playas of Harper, Mirage, Rosamond, and Koehn Lakes. Alluvial sand along the Mojave River flood plain also gives large yields at shallow depths.

\section{GROUND-W ATER RESER VOIRS}

The largest ground-water reservoirs in the western Mojave Desert are in the extensive bajadas and alluviated plains that slope from the mountains of the southwestern and northwestern borders. The most extensive of these reserves are under Antelope Valley and in the vicinity of the Mojave River, where ground water is pumped extensively for irrigation. Most of the numerous wells pump several hundred gallons per minute from depths between 50 and 200 feet. In the higher parts of the alluviated plain, depths to ground water are generally too great to permit economical pumping. Less extensive areas under irrigation from water wells are in the valley area southwest of Koehn Lake, and in that southwest of Harper Lake.
Ground water in the outlying undrained desert valleys, such as that south of Atolia and that of Cuddeback Lake, is derived only from the small amount of precipitation that falls on their respective drainage areas. The ground-water reserves of these desert valleys are therefore very limited and insufficient for large-scale irrigation.

\section{MAGMATTC WATER}

Water of magmatic origin generally issues at the surface in the form of hot springs, steam, or highly mineralized springs. Such water must have been abundant during and after volcanic activity in Tertiary times in the desert region. At present there is only one known occurrence of magmatic water within the area, and that is through a well in the southwestern Lava Mountains about 6 miles east of Johannesburg (w31, table 4). This well, said to have been drilled for quicksilver in about 1920, is 415 feet deep in Pliocene andesite (W. R. Moyle, written commun., 1960). It struck hot water, steam, and hydrogen sulfide gas, which have been issuing ever since.

\section{REFERENCES CITED}

Axelrod, D. I., 1950, The Piru Gorge flora of southern California: Carnegie Inst. Washington Pub. 590, Contr. Paleontology, p. 159-214.

Bader, J. S., Page, R. W., and Dutcher, L. C., 1958, Data on water wells in the upper Mojave Valley area, San Bernardino County, California: U.S. Geol. Survey open-file report, $238 \mathrm{p}$.

Baker, C. L., 1911, Notes on the later Cenozoic history of the Mojave Desert region in southeastern California: California Univ., Dept. Geology Bull., v. 6, no. 15, p. 333-383.

1912, Physiography and structure of the western El Paso Range and the southern Sierra Nevada: California Univ., Dept. Geology Bull., v. 7, no. 6, p. 117-142.

Benda, W. K., Erd, R. C., and Smith, W. C., 1960, Core logs from five test holes near Kramer, California: U.S. Geol. Survey Bull. 1045-F, p. 319-393.

Blake, W. P., 1857, Geological report, in Williamson, R. S., Report on exploration for railroad route from Mississippi River to Pacific Ocean in 1853, v. 5, pt. 2 of U.S., Pacific R. R. Explor.: U.S. 33d Cong., 2d sess., S. Ex. Doc. 78 and H. Ex. Doc. 91, 370 p.

Bowen, O. E., Jr., 1954, Geology and mineral deposits of Barstow quadrangle; San Bernardino County, California: California Div. Mines Bull. 165, pp. 7-185.

Buwalda, J. P., 1916, New mammalian faunas from Miocene sediments near Tehachapi Pass in the southern Sierra Nevada: California Univ., Dept. Geology Bull., v. 10, no. 6, p. 75-85.

1954, Geology of the Tehachapi Mountains, California, [pt.] 9, in Jahns, R. H., ed., Geology of southern California: California Div. Mines Bull. 170, p. 131-142.

Buwalda, J. P., and Lewis, G. E., 1955, A new species of Merychippus [California]: U.S. Geol. Survey Prof. Paper 264-G, p. 147-152. 
California Division of Mines, 1943, Tabulated data on wells drilled outside of the principal oil and gas fields: California Div. Mines Bull. 118, p. 636-664.

Clements, Thomas, 1937, Structure of southeastern part of Tejon quadrangle, California: Am. Assoc. Petroleum Geologists Bull., v. 21, no. 2, p. 212-232.

Crowell, J. C., 1950, Geology of Hungry Valley area, southern California: Am. Assoc. Petroleum Geologists Bull., v. 34, no. 8 , p. $1623-1646$.

- 1952, Geology of the Lebec quadrangle, California: California Div. Mines Spec. Rept. 24, 23 p.

1954, Geology of the Ridge basin area, Los Angeles and Ventura Counties, California, in Jahns, R. H., ed., Geology of southern California: California Div. Mines Bull. 170, map sheet 7 .

Darton, N. H., and others, 1915, The Santa Fe Route, with a side trip to the Grand Canyon of the Colorado, pt. C of Guidebook of the western United States: U.S. Geol. Survey Bull. 613, $200 \mathrm{p}$.

David, L. R., 1945, A Neogene stickleback from the Ridge formation of California: Jour. Paleontology, v. 19, no. 3, p. 315-318.

Dibblee, 'T. W., Jr., 1952, Geology of the Saltdale quadrangle, Kern County, California: California Div. Mines Bull. 160 , p. 7-43.

1958a, Geologic map of the Boron quadrangle, Kern and San Bernardino Counties, California: U.S. Geol. Survey Mineral Inv. Field Studies Map MF-204, scale 1:62,500. $-1958 \mathrm{~b}$, Geologic map of the Castle Butte quadrangle, Kern County, California: U.S. Geol. Survey Mineral Inv. Field Studies Map MF-170, scale 1:62,500.

-1958c, Tertiary stratigraphic units of western Mojave Desert, California: Am. Assoc. Petroleum Geologists Bull., v. 42 , no. 1 , p. 135-144.

1959a, Geologic map of the Alpine Butte quadrangle, California: U.S. Geol. Survey Mineral Inv. Field Studies Map MF-222, scale 1:62,500.

$-1959 \mathrm{~b}$, Preliminary geologic map of the Mojave quadrangle, California: U.S. Geol. Survey Mineral Inv. Field Studies Map MF-219, scale 1:62,500.

- 1960a, Geologic map of the Barstow quadrangle, San Bernardino County, California: U.S. Geol. Survey Mineral Inv. Field Studies Map MF-233, scale 1:62,500.

- 1960b, Geologic map of the Hawes quadrangle, San Bernardino County, California: U.S. Geol. Survey Mineral Inv. Field Studies Map MF-226, scale 1:62,500.

-1960c, Geologic map of the Lancaster quadrangle, Los Angeles County, California: U.S. Geol. Survey Mineral Inv. Field Studies Map MF-76, scale 1:62,500 [1961].

1960d, Geology of the Rogers Lake and Kramer quadrangles, California: U.S. Geol. Survey Bull. 1089-B, p. 73-139 [1961].

- $1960 \mathrm{e}$, Preliminary geologic map of the Apple Valley quadrangle, California: U.S. Geol. Survey Mineral Inv. Field Studies Map MF-232, scale 1:62, 500.

-1960f, Preliminary geologic map of the Shadow Mountains quadrangle, Los Angeles and San Bernardino Counties, California: U.S. Geol. Survey Mineral Inv. Field Studies Map MF-227, scale 1:62,500.

- 1960g, Preliminary geologic map of the Victorville quadrangle, California: U.S. Geol. Survey Mineral Inv. Field Studies Map MF-229, scale 1:62,500.

- 1961a, Evidence of strike-slip movement on northwesttrending faults in Mojave Desert, California, in Short papers in the geologic and hydrologic sciences: U.S. Geol. Survey Prof. Paper 424-B, p. B197-B199.

Dibblee, T. W., Jr., 1961b, Geologic map of the Bouquet Reservoir quadrangle, Los Angeles County, California: U.S. Geol. Survey Mineral Inv. Field Studies Map MF-79, scale $1: 62,500$.

1963, Geology of the Willow Springs and Rosamond quadrangles, California: U.S. Geol. Survey Bull. 1089-C, p. 141253.

1967, Geology of the Opal Mountain and Fremont Peak quadrangles, California: California Div. Mines and Geology Spec. Rept. (In press.)

Dibblee, T. W., Jr., and Chesterman, C. W., 1953, Geology of the Breckenridge Mountain quadrangle, California: California Div. Mines Bull. 168, 56 p.

Dibblee, T. W., Jr., and Gay, T. E., Jr., 1952, Mineral deposits of Saltdale quadrangle [California]: California Div. Mines Bull. 160, p. 45-64.

Dickerson, R. E., 1914, The Martinez Eocene and associated formations at Rock Creek on the western border of the Mohave Desert area [California]: California Univ., Dept. Geology Bull., v. 8, no. 14, p. 289-298.

Dickey, D. D., 1957, Core logs from two holes near Kramer, San Bernardino County, California: U.S. Geol. Survey Bull. 1045-B, p. 63-79.

Durham, J. W., Jahns, R. H., and Savage, D. E., 1954, Marinenonmarine relationships in the Cenozoic section of California, [pt.] 7, in Jahns, R. H., ed., Geology of southern California: California Div. Mines Bull. 170, p. 59-71.

Durrell, Cordell, 1953, Geological investigations of strontium deposits in southern California: California Div. Mines Spec. Rept. $32,48 \mathrm{p}$.

Dutcher, L. C., 1959, Data on water wells in the Fremont Valley area, Kern County, California: U.S. Geol. Survey open-file report, $128 \mathrm{p}$.

Eaton, J. E., 1939, Ridge Basin, California: Am. Assoc. Petroleum Geologists Bull., v. 23, no. 4, p. 517-558.

Ehlig, P. L., 1959, Relationship of the Pelona Schist and Vincent thrust in the San Gabriel Mountains, California [abs.]: Geol. Soc. America Bull., v. 70, no. 12, pt. 2, p. 1717.

Gale, H. S., 1926, Borate deposits near Kramer, California: Am. Inst. Mining Metall. Engineers Trans. [preprint] 1553, 15 p.; also v. 73, p. 449-463.

Gale, H. S., 1946, Geology of the Kramer borate district, Kern County, California: California Jour. Mines and Geology, v. 42 , no. 4 , p. $325-378$.

Gardner, D. L., 1940, Geology of the Newberry and Ord Mountains, San Bernardino County, California: California Jour. Mines and Geology, v. 36, no. 3, p. 257-292.

Gay, T. E., Jr., and Hoffman, S. R., 1954, Mines and mineral deposits of Los Angeles County, California: California Jour. Mines and Geology, v. 50, p. 467-709.

Griswold, W. T., 1959, Colemanite as an important source of borates: Am. Inst. Mining. Metall. Engineers, Ann. Mtg., San Francisco, 1959: Soc. Mining Engineers Preprint $59 \mathrm{H} 20,2 \mathrm{p}$.

Hershey, O. H., 1902a, Some crystalline rocks of southern California: Am. Geologist, v. 29, p. 273-290.

$1902 \mathrm{~b}$, Some Tertiary formations of southern California: Am. Geologist, v. 29, p. 349-372.

1902c, The Quaternary of southern California: California Univ., Dept. Geology Bull., v. 3, no. 1, p. 1-29.

Hess, F. L., 1910, Gold mining in the Randsburg quadrangle, California: U.S. Geol. Survey Bull. 430-A, p. 23-47. 
Hewett, D. F., 1954a, A fault map of the Mojave Desert region [California], [pt.] 2, in Jahns, R. H., ed., Geology of southern California: California Div. Mines Bull. 170, p. 15-18, pl. 1. - 1954b, General geology of the Mojave Desert region, California, [pt.] 1, in Jahns, R. H., ed., Geology of southern California: California Div. Mines Bull. 170, p. 5-20.

Hewett, D. F., Callaghan, Eugene, Moore, B. N., Nolan, T. B., Rubey, W. W., and Schaller, W. T., 1936, Mineral resources of the region around Boulder Dam: U.S. Geol. Survey Bull. $871,197 \mathrm{p}$.

Hill, M. L., and Dibblee, T. W., Jr., 1953, San Andreas, Garlock, and Big Pine faults, California-a study of the character, history, and tectonic significance of their displacements: Geol. Soc. America Bull., v. 64, no. 4, p. 443-458.

Hoots, H. W., 1930, Geology and oil resources along the southern border of San Joaquin Valley, California: U.S. Geol. Survey Bull. 812-D, p. 243-332.

Hulin, C. D., 1925, Geology and ore deposits of the Randsburg quadrangle, California: California Mining Bur. Bull. 95, $152 \mathrm{p}$.

Huttl, J. B., 1958, U.S. Borax has integrated a complex industrial plant: Eng. Mining Jour., v. 159, no. 4, p. 101-105.

Jahns, R. H., 1939, Miocene stratigraphy of the easternmost Ventura Basin, California, a preliminary statement: Am. Jour. Sci., v. 237, no. 11, p. 818-825.

1940, Stratigraphy of the easternmost Ventura Basin, California, with a description of a new lower Miocene mammalian fauna from the Tick Canyon formation: Carnegie Inst. Washington Pub. 514, p. 145-194.

Jahns, R. H., and Muehlberger, W. R., 1954, Geology of the Soledad basin, Los Angeles County, in Jahns, R. H., ed., Geology of southern California: California Div. Mines Bull. 170 , map sheet 6 .

Jennings, C. W., 1953, Geology of the southern part of the Quail quadrangle, California: California Div. Mines Spec. Rept. 30, 18 p.

Jennings, C. W., and Hart, E. W., 1956, Exploratory wells drilled outside of oil and gas fields in California to December 31, 1953: California Div. Mines Spec. Rept. 45, 104 p.

Johnson, H. R., 1911, Water resources of Antelope Valley, California: U.S. Geol. Survey Water-Supply Paper 278, 92 p.

Kerr, P. F., 1946, Tungsten mineralization in the United States: Geol. Soc. America Mem. 15, 241 p.

Kew, W. S. W., 1924, Geology and oil resources of a part of Los Angeles and Ventura Counties, California: U.S. Geol. Survey Bull. 753, 202 p.

Knopf, Adolph, 1918, Strontianite deposits near Barstow, California: U.S. Geol. Survey Bull. 660-I, p. 257-270.

Kunkel, Fred, 1956, Data on water wells in Cuddeback, Superior, and Harper Valleys, San Bernardino County, California: U.S. Geol. Survey open-file report, 73 p.

- 1962, Reconnaissance of ground water in the western part of the Mojave Desert region, California: U.S. Geol. Survey Hydrol. Inv. Atlas HA-31, scale 1:316,800.

Kunkel, Fred, and others, 1957, Data on water wells in the Willow Springs, Gloster, and Chaffee areas, Kern County, California: U.S. Geol. Survey open-file report, $67 \mathrm{p}$.

Lemmon, D. M., and Dorr, J. V. N., 2d, 1940, Tungsten deposits of the Atolia district, San Bernardino and Kern Counties, California: U.S. Geol. Survey Bull. 922-H, p. 205-245.

Lewis, G. E., 1964, Miocene vertebrates of the Barstow Formation in southern California, in Short papers in the geologic and hydrologic sciences: U.S. Geol. Survey Prof. Paper 475-D, p. D18-D22.
McCulloh, T. H., 1952, Geology of the southern half of the Lane Mountain quadrangle, California: California Univ., Los Angeles, Ph.D. thesis.

McKenna, M. C., 1960, A continental Paleocene vertebrate fauna from California: Am. Mus. Novitates, no. 2024, 20 p.

Mabey, D. R., 1960, Gravity survey of the western Mojave Desert, California: U.S. Geol. Survey Prof. Paper 316-D, p. 51-73.

Merriam, J. C., 1907, The occurrence of middle Tertiary mammalbearing beds in northwestern Nevada: Science, new ser., v. 26 , p. $380-382$.

1911, A collection of mammalian remains from Tertiary beds on the Mohave Desert [California]: California Univ., Dept. Geology Bull., v. 6, no. 7, p. 167-169.

- 1 1914, The occurrence of Tertiary mammalian remains in northeastern Nevada: California Univ., Dept. Geology Bull., v. 8, no. 12, p. 275-281.

- 1915, Extinct faunas of the Mojave Desert, their significance in a study of the origin and evolution of life in America: Pop. Sci. Monthly, v. 86, p. 245-264.

1917, Relationships of Pliocene mammalian faunas from the Pacific Coast and Great Basin provinces of North America: California Univ., Dept. Geology Bull., v. 10, no. 22, p. 421-443.

- 1919, Tertiary mammalian faunas of the Mohave Desert: California Univ., Dept. Geology Bull., v. 11, no. 5, p. 437a437e, 438-585.

Miller, W. J., 1944, Geology of parts of the Barstow quadrangle, San Bernardino County, California: California Jour. Mines and Geology, v. 40, no. 1, p. 73-112.

Miller, W. J., and Webb, R. W., 1940, Descriptive geology of the Kernville quadrangle, California: California Jour. Mines and Geology, v. 36, no. 4, p. 343-378.

Muehlberger, W. R., 1958, Geology of northern Soledad basin, Los Angeles County, California: Am. Assoc. Petroleum Geologists Bull., v. 42, no. 8, p. 1812-1844.

Muehlberger, W. R., and Hill, H.S., 1958, Geology of the central Sierra Pelona, Los Angeles County, California: Am. Jour. Sci., v. 256 , no. 9 , p. 630-643.

Muessig, S. J., and Allen, R. D., 1957, The hydration of kernite $\left(\mathrm{Na}_{2} \mathrm{~B}_{4} \mathrm{O}, .4 \mathrm{H}_{2} \mathrm{O}\right)$ : Am. Mineralogist, v. 42, nos. 9-10, p. 699701.

Nelson, H. E., 1957, Uranium occurrences in the Mojave mining district, Kern County, California: U.S. Atomic Energy Comm. RME-2058, issued by Tech. Inf. Serv., Dept. Commerce, Washington 25, D.C., 27 p.

Neuerburg, G. J., and Gottfried, David, 1954, Age determinations of the San Gabriel anorthosite massif, California: Geol. Soc. America Bull., v. 65, no. 5, p. 465.

Noble, J. A., 1954, Geology of the Rosamond Hills, Kern County, in Jahns, R. H., ed., Geology of southern California: California Div. Mines Bull. 170, map sheet 14.

Noble, L. F., 1926, Borate deposits in the Kramer district, Kern County, California: U.S. Geol. Survey Bull. 785-C, p. 45-61. 1932, Excursion to the San Andreas fault and Cajon Pass, in Gale, H. S., and others, Southern California: Internat. Geol. Cong., 16th, Washington 1933, Guidebook 15, Excursion $\mathrm{C}-1$, p. 10-21.

1953, Geology of the Pearland quadrangle, California: U.S. Geol. Survey Geol. Quad. Map GQ-24, scale $1: 24,000$. - 1954a, Geology of the Valyermo quadrangle and vicinity, California: U.S. Geol. Survey Geol. Quad. Map GQ-50, scale $1: 24,000$. 
Noble, L. F., 1954b, The San Andreas fault zone from Soledad Pass to Cajon Pass, California, [Pt.] 5, in Jahns, R. H., ed., Geology of southern California: California Div. Mines Bull. 170, p. $37-48$.

Oakeshott, G. B., 1958, Geology and mineral deposits of San Fernando quadrangle, Los Angeles County, California: California Div. Mines Bull. 172, 147 p.

Oakeshott, G. B., Braun, L. T., Jennings, C. W., and Wells, Ruth, 1952, Exploratory wells drilled outside of oil and gas fields in California to December 31, 1950: California Div. Mines Spec. Rept. 23, 77 p.

Pack, R. W., 1914a, Ornamental marble near Barstow, California: U.S. Geol. Survey Bull. 540-K, p. 363-368.

1914b, Reconnaissance of the Barstow-Kramer region, California: U.S. Geol. Survey Bull. 541-E, p. 141-154.

Page, R. W., and Moyle, W. R., Jr., 1960, Data on water wells in the eastern part of the middle Mojave Valley area, San Bernardino County, California: California Dept. Water Resources Bull. 91-3, 223 p. (map 33c).

Page, R. W., Moyle, W. R., Jr., and Dutcher, L. C., 1960, Data on wells in the west part of the middle Mojave Valley area, San Bernardino County, California: California Dept. Water Resources Bull. 91-1, $126 \mathrm{p}$.

Richmond, J. F., 1960, Geology of the San Bernardino Mountains north of Big Bear Lake, California: California Div. Mines Spec. Rept. 65, 68 p.

Savage, D. E., Downs, Theodore, and Poe, O. J., 1954, Cenozuic land life of southern California, [pt.] 6, in.Jahns, R. H., ed., Geology of southern California: California Div. Mines Bull. 170, p. 43-58.

Schaller, W. T., 1930, Borate minerals from the Kramer district, Mohave Desert, California: U.S. Geol. Survey Prof. Paper 158-1, p. 137-173.

Sharp, R. P., 1935, Geology of Ravenna quadrangle, California [abs.]: Pan-Am. Geologist, v. 63, p. 314.

Simpson, E. C., 1934, Geology and mineral deposits of the Elizabeth Lake quadrangle, California: California Jour. Mines and Geology, v. 30, no. 4, p. 371-415.

Smith, G. I., 1960, Estimate of total displacement on the Garlock fault, southeastern California [abs.]: Geol. Soc. America Bull., v. 71 ; no. 12 , pt. 2 , p. 1979.

- 1964, Geology and volcanic petrology of the Lava Mountains, San Bernardino County, California: U.S. Geol. Survey Prof. Paper 457, 97 p.

Smith, W. C., 1958, Borate deposits of the Mojave region, California: Mines Mag., v. 48, no. 7, p. 23-26, 36.

1960, Borax and borates, in Industrial minerals and rocks [3d ed.]: New York, Am. Inst. Mining Metall. Engineers, p. 103-118.

Stock, Chester, 1920, An early Tertiary vertebrate fauna from the southern coast ranges of California: California Univ., Dept. Geology Bull., v. 12, no. 4, p. 267-276.

1932, Additions to the mammalian fauna from the Tecuya beds, California: Carnegie Inst. Washington Pub. 418, Contr. Paleontology, p. 87-92.

Thompson, D. G., 1929, The Mohave Desert region, California, a geographic, geologic, and hydrologic reconnaissance: U.S. Geol. Survey Water-Supply Paper 578, 759 p.
Troxel, B. W., 1954, Geology of a part of the Shadow Mountains, western San Bernardino County [California], in Jahns, R. H., ed., Geology of southern California: California Div. Mines Bull. 170, Map Sheet 15, scale 3 inches $=1$ mile.

Troxel, B. W., and Morton, P. K., 1962, Mines and mineral resources of Kern County, California: California Div. Mines and Geology County Rept. 1, 370 p.

Troxell, H. C., and Hoffman, Walter, 1954, Hydrology of the Mojave Desert, [pt.] 2 in Jahns, R. H., ed., Geology of southern California: California Div. Mines Bull. 170, p. 13-17.

Tucker, W. B., 1929, Kern County [California]: California Div. Mines and Mining, 25th Rept. State Mineralogist, p. 20-81.

Tucker, W. B., Sampson, R. J., and Oakeshott, G. B., 1949, Mineral resources of Kern County [California]: California Jour. Mines and Geology, v. 45, no. 2, p. 203-297.

Vaughan, F. T., 1922, Geology of San Bernardino Mountains north of San Gorgonio Pass [California]: California Univ., Dept. Geol. Sci. Bull., v. 13, no. 9, p. 319-411.

Ver Planck, W. E., 1952, Gypsum in California: California Div. Mines Bull. 163, $151 \mathrm{p}$.

1957, Boron, in Mineral commodities of California: $\chi$ California Div. Mines Bull. 176, p. 87-94.

Walker, G. W., Lovering, T. G., and Stephens, H. G., 1956, Radioactive deposits in California: California Div. Mines Spec. Rept. 49, 38 p.

Wallace, R. E., 1949, Structure of a portion of the San Andreas rift in southern California: Geol. Soc. America Bull., v. 60, no. 4, p. 781-806.

Waters, A. C., and Campbell, C. D., 1935, Mylonites from the San Andreas fault zone: Am. Jour. Sci., 5th ser., v. 29, no. 174, p. 473-503.

Weiss, L. E., 1954, A study of tectonic style-structural investigation of a marble-quartzite complex in southern California: California Univ., Dept. Geol. Sci. Bull., v. 30, no. 1, p. 1-102.

Wiese, J. H., 1950, Geology and mineral resources of the Neenach quadrangle, California: California Div. Mines Bull. 153, $53 \mathrm{p}$.

Wiese, J. H., and Fine, S. F., 1950, Structural features of western Antelope Valley, California: Am. Assoc. Petroleum Geologists Bull., v. 34, no. 8, p. 1647-1658.

Wood, H. E., 2d, and others, 1941, Nomenclature and correlation of the North American continental Tertiary: Geol. Soc. America Bull., v. 52, no. 1, p. 1-48.

Woodford, A. O., and Harris, T. F., 1928, Geology of Blackhawk Canyon, San Bernardino Mountains, California: California Univ., Dept. Geol. Sci. Bull., v. 17, no. 8, p. 265-304.

Wright, L. A., Stewart, R. M., Gay, T. E., Jr., and Hazenbush G. C., 1953, Mines and mineral deposits of San Bernardino County, California: California Jour. Mines and Geology, v. 49, nos. 1-2, p. 49-257, and tabulated list, 192 p.

Wright, L. A., and Troxel, B. W., 1954, Western Mojave Desert and Death Valley region, [pt.] 1 in Jahns, R. H., ed., Geology of southern California: California Div. Mines Bull. $170,50 \mathrm{p}$. 

TABLES 2-4 
TABLE 2.-Tabulated list of borate mines in Kramer borate district

[Locations of mines shown on fig. 46; geologic symbols defined on pl. 1]

\begin{tabular}{|c|c|c|c|c|c|c|c|}
\hline (fig. 46) & $\begin{array}{l}\text { Mine, claim, or } \\
\text { group (owner) }\end{array}$ & Location & When active & Geology & Development work & $\begin{array}{l}\text { Approximste } \\
\text { production }\end{array}$ & Source of data \\
\hline 1. & Suckow shaft $1 \ldots$ & $\begin{array}{l}1,300 \pm \text { ft south, } \\
1,500 \pm \text { ft west of } \\
\text { NE cor. sec. } 22, T \text {. } \\
11 \text { N., R. } 8 \text { W. }\end{array}$ & $1924 \ldots$ & $\begin{array}{l}\text { Tsb at bottom of shaft, very } \\
\text { little shale above, no } \\
\text { borates. }\end{array}$ & Vertical 180-ft shaft . . . . . & None......... & $\begin{array}{l}\text { Noble (1926a, p. } \\
51) \text {. }\end{array}$ \\
\hline $2 \ldots .$. & Slosser shaft....... & $\begin{array}{l}1,300 \pm \text { it south, } \\
1,100 \pm \text { ft west of } \\
\text { NE cor. sec. } 22, T \text {. } \\
11 \text { N., R. } 8 \text { W. }\end{array}$ & $1924 \ldots$ & $\begin{array}{l}\text { Borate nodules in sh at depth } \\
\text { of } 110 \mathrm{ft} \text {, Tsb at bottom of } \\
\text { shaft. }\end{array}$ & $\begin{array}{l}\text { Vertical shaft, slightly } \\
\text { deeper than } 110 \mathrm{ft} \text {. }\end{array}$ & & Do. \\
\hline $3 \ldots$ & Ulexite shaft. .... & $\begin{array}{l}1,700 \pm \mathrm{ft} \text { south, } 500 \pm \\
\mathrm{ft} \text { west of } \mathrm{NE} \text { cor. } \\
\text { sec. } 22, T .11 \text { N., R. } \\
8 \mathrm{w} \text {. }\end{array}$ & $1824 \ldots$ & $\begin{array}{l}10-15 \mathrm{ft} \text { of ulexite at bottom of } \\
\text { shaft. }\end{array}$ & Vertical 110-ft shaft........ & (n) & Do. \\
\hline & Suckow shaft 2... & $\begin{array}{l}2,600 \pm \mathrm{ft} \text { south, } \\
1,600 \pm \text { ft west of } \\
\text { NE cor. sec. } 22, T \text {. } \\
11 \text { N., R. } 8 \text { W. }\end{array}$ & $1924 \ldots$ & $\begin{array}{l}\text { Log of shaft: 0-105 ft sd, grv } \\
\text { (Qa); 105-180 ft sh (Ttu), } \\
\text { sandy, some volcanic ash; } \\
180-220 \mathrm{ft} \text { ss (Ttu), dips } 25^{\circ} \\
\text { SW.; } 220-280 \mathrm{ft} \text { sh (Ttu), } \\
\text { lenses and nodules of cole- } \\
\text { manite, dips } 25^{\circ} \mathrm{SW} \text {; } 280- \\
\text { 300 ft basalt (Tsb). In tun- } \\
\text { nel Ttu dips } 50^{\circ}-80^{\circ} \mathrm{SW} \text {. }\end{array}$ & $\begin{array}{l}\text { Vertical 300-ft shaft, short } \\
\text { tunnel driven west } \\
\text { from bottom. }\end{array}$ & $\begin{array}{l}\text { Small output } \\
\text { of cole- } \\
\text { manite. }\end{array}$ & $\begin{array}{l}\text { Noble }(1926 \mathrm{a}, \\
\text { p. } 49) \text {. }\end{array}$ \\
\hline $5 \ldots$ & $\begin{array}{l}\text { West Baker; } \\
\text { formerly Suc- } \\
\text { kow Borax } \\
\text { (U.S. Borax \& } \\
\text { Chemical } \\
\text { Corp.). }\end{array}$ & $\begin{array}{l}\text { SE1/4 sec. 14, NE1/4 } \\
\text { sec. } 23, \mathrm{~T} .11 \mathrm{~N} ., \\
\text { R. } 8 \text { W. }\end{array}$ & 1927-57. & $\begin{array}{l}\text { Log of shaft (alt 2,445 ft): } \\
0-185 \mathrm{ft} \text { sd (Qa and Q0a); } \\
185-200 \mathrm{ft} \text { ss (Ttu); } 200-280 \\
\mathrm{ft} \text { sh (T tu); } 280-331 \mathrm{ft} \text { sh } \\
\text { (Ttu), contains colemanite } \\
\text { and ulexite nodules; } 331-417 \\
\text { ft borax and sh (Ttu); } 417- \\
\text { 431 ft sh (Ttu), on Tsb(?). } \\
\text { Ttu and ore body gently } \\
\text { folded. }\end{array}$ & $\begin{array}{l}\text { Vertical shaft ( } 85 \mathrm{ft} \text { north, } \\
750 \mathrm{ft} \text { east of } \mathrm{S} 1 / 4 \text { cor. } \\
\text { sec. 14) } 431 \mathrm{ft} \text { deep; } \\
\text { main level at } 380 \mathrm{ft} \text {; } \\
\text { numerous workings in } \\
\text { ore body, connecting } \\
\text { south and east with ad- } \\
\text { jacent mines. }\end{array}$ & $\begin{array}{l}187,000 \text { tons } \\
\text { of borate } \\
\text { ore mined } \\
\text { before } 1943 .\end{array}$ & $\begin{array}{l}\text { Gale (1946, p. 361- } \\
\text { 363); Tucker and } \\
\text { others (1949, } \\
\text { p. 244). }\end{array}$ \\
\hline $6 \ldots \ldots$ & $\begin{array}{l}\text { Baker mine (U.S. } \\
\text { Borax \& Chem- } \\
\text { ical Corp.). }\end{array}$ & $\begin{array}{l}\text { S1/2 sec. } 13, \text { N1/2 sec. } \\
24, T .11 \text { N., R. } 8 \\
\text { W.; SW } 1 / 4 \text { sec. } 18, \\
\text { NW1/4 sec. } 19 . T . \\
11 \text { N., R. } 7 \text { W. }\end{array}$ & $1927-57 \ldots$ & $\begin{array}{l}\text { Log of main shaft (alt 2,500 } \\
\text { ft): 0-325 ft sd, grv (Qa and } \\
\text { Qoa); 325-393 ft sh (Ttu), } \\
\text { contains colemanite and } \\
\text { ulexite nodules; } 393-498 \mathrm{ft} \\
\text { sodium borates and sh } \\
\text { (Ttu); 498-540 ft sh (Ttu), } \\
\text { ulexite seams. Ttu and } \\
\text { ore body gently folded. }\end{array}$ & $\begin{array}{l}\text { Maln shaft ( } 450 \mathrm{ft} \text { south, } \\
300 \mathrm{ft} \text { east of } \mathrm{NW} \text { cor. } \\
\text { sec. 19) } 540 \mathrm{ft} \text { deep; } 2 \\
\text { others nearby, each } 470 \\
\text { ft deep; numerous } \\
\text { workings in ore body to } \\
\text { adjacent mines; mill. }\end{array}$ & $\begin{array}{l}\text { Several hun- } \\
\text { dred thou- } \\
\text { sand tons of } \\
\text { borate ore. }\end{array}$ & $\begin{array}{l}\text { Tucker (1929, p. } \\
\text { 77-79); Noble } \\
\text { (1926a); Gale } \\
\text { (1946); Tucker } \\
\text { and others, } \\
\text { (1949, p. } 243- \\
\text { 244). }\end{array}$ \\
\hline & $\begin{array}{l}\text { Jennifer mine } \\
\text { (U.S. Borax \& } \\
\text { Chemical } \\
\text { Corp.). }\end{array}$ & $\begin{array}{l}\text { NE1/4 sec. } 23, \text { NW14 } \\
\text { sec. } 24, T .11 \text { N., } \\
\text { R. } 8 \text { W. }\end{array}$ & $1950-57 \ldots \ldots$ & $\begin{array}{l}\text { Top of ore body at depth of } \\
\text { about } 300 \mathrm{ft} \text {; nearly } 200 \mathrm{ft} \\
\text { thick; top Tsb, } 514 \text { ft. Ttu } \\
\text { and ore body gently folded. }\end{array}$ & $\begin{array}{l}2 \text { shafts }(1,400 \pm \text { ft south } \\
\text { of } N W \text { cor. sec. } 24) \\
\text { each about } 500 \mathrm{ft} \text { deep; } \\
\text { numerous workings in }\end{array}$ & $\begin{array}{l}\text { Large ton- } \\
\text { nage of } \\
\text { borate ore. }\end{array}$ & \\
\hline $8 . \ldots$. & $\begin{array}{l}\text { Open Pit borate } \\
\text { mine (U.S. } \\
\text { Borax \& Chem- } \\
\text { ical Corp.). }\end{array}$ & $\begin{array}{l}\text { NE1/4 sec. } 23, \text { T. } 11 \\
\text { N., R. } 8 \text { W. }\end{array}$ & Since $1957 \ldots$ & $\begin{array}{l}\text { Borax ore body in Ttu, dips } \\
\text { gently NE and SE from } \\
\text { faulted anticlinal axis; top } \\
\text { of ore body struck at depth } \\
\text { of } 137 \mathrm{ft} \text { at one place, ore to } \\
\text { bottom of pit; stratigraphic } \\
\text { sequence as follows: } 60 \mathrm{ft} \\
\text { sd, grv (Qa), } 70 \mathrm{ft} \text { ss (Ttu); } \\
70 \mathrm{ft} \text { sh (Ttu), contains } \\
\text { colemanite and ulexite } \\
\text { nodules; } 150 \mathrm{ft} \text { borax and } \\
\text { minor sh (Ttu), on Tsb. }\end{array}$ & $\begin{array}{l}\text { Large oval pit } 2,000 \mathrm{ft} \\
\text { long, } 1,700 \mathrm{ft} \text { wide, } 275 \\
\text { ft deep; being enlarged. }\end{array}$ & $\begin{array}{l}\text { Large ton- } \\
\text { nage of } \\
\text { borate ore. }\end{array}$ & $\begin{array}{l}\text { Ver Planck.(1957, } \\
\text { p. 93); Smith } \\
\text { (1960, p. 110- } \\
\text { 113) (U.s. } \\
\text { Borax \& Chem- } \\
\text { ical Corp.). }\end{array}$ \\
\hline 8..... & $\begin{array}{l}\text { Mudd Borate } \\
\text { mine; formerly } \\
\text { Western Borax } \\
\text { and Little } \\
\text { Placer Mines } \\
\text { (Callfornia } \\
\text { Borate Co.). }\end{array}$ & $\begin{array}{l}\text { S1/ sec. } 24, \text { T. } 11 \text { N., } \\
\text { R. } 8 \text { W. }\end{array}$ & $\begin{array}{l}\text { 1927-33: ex- } \\
\text { ploration } \\
\text { work since } \\
\text { 1933. }\end{array}$ & $\begin{array}{l}\text { Log of No. } 3 \text { shaft (alt } 2,470 \\
\text { ft): } 0-770 \pm \text { ft sd and fg } \\
\text { (Qa, Q08, and Qof); 770 } \\
820 \mathrm{ft} \text { sn and ss (Ttu); } 820- \\
1,100 \pm \text { ft sh (Ttu), con- } \\
\text { tains nodules and strata of } \\
\text { colemanite and ulexite near } \\
\text { middle (kernite ore body, } \\
\text { max. thickness } 200 \mathrm{ft} \text {, in } \\
\text { this shale north of shaft); } \\
1,100 \pm-1,210 \text { ft granitic cg } \\
\text { (Ttl). }\end{array}$ & $\begin{array}{l}2 \text { vertical shaits, No. } 1 \\
\text { shaft ( } 290 \mathrm{ft} \text { south, } 350 \\
\text { ft west of center of } \\
\text { sec. } 24) 896 \mathrm{ft} \text { deep; } \\
\text { crosscut at } 856 \mathrm{ft} \mathrm{driven} \\
\mathrm{N} .6^{\circ} \mathrm{E} \text {. to ore body; } \\
\text { No. } 3 \text { shaft (420 ft } \\
\text { south, } 220 \mathrm{ft} \text { east of } \\
\text { center sec. 24) } 1,210 \mathrm{ft} \\
\text { deep, levels at } 900 \mathrm{ft}, \\
1,210 \mathrm{ft} \text {, driven north } \\
\text { to ore body; many } \\
\text { workings in }\end{array}$ & $\begin{array}{l}160,000 \text { tons } \\
\text { of borate } \\
\text { ore before } \\
1933 .\end{array}$ & $\begin{array}{l}\text { Tucker (1829, } \\
\text { p. 80) Gale } \\
\text { (1946, p. 363- } \\
369) \text {. }\end{array}$ \\
\hline 10. & Russell shaft.... & $\begin{array}{l}\text { SW cor. NE14 sec. } 18, \\
\text { T. } 11 \text { N., R. } 7 \text { W. }\end{array}$ & $1828(?) \ldots$ & 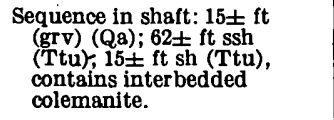 & $\begin{array}{l}\text { Vertical shaft about } 92 \mathrm{ft} \\
\text { deep. }\end{array}$ & None...... & Gale (1946). \\
\hline
\end{tabular}


TABLE 3.-Exploratory test holes drilled for minerals in western Mojave Desert region

[Most test holes drilled in search of borate minerals in Kramer (Boron) and East Kramer borate districts, and on or near Koehn and Harper Lakes (no borates penetrated unless indicated); three test holes were drilled for salt brine at Saltdale near Koehn Lake; several test holes were drilled for water in Kramer and East Kramer borate or areas, townships and sections, generally from north to south, west to east]

\begin{tabular}{|c|c|c|c|c|c|c|c|c|c|c|c|}
\hline \multirow{2}{*}{$\begin{array}{l}\text { Number } \\
\text { on maps }\end{array}$} & \multirow{2}{*}{ Operator } & \multirow{2}{*}{ Hole } & \multicolumn{3}{|c|}{ Location } & \multirow{2}{*}{$\underset{\text { drilled }}{\text { Year }}$} & \multirow{2}{*}{$\begin{array}{l}\text { Source of } \\
\text { data }\end{array}$} & \multirow{2}{*}{$\underset{\text { (feet) }}{\text { Altitude }}$} & \multicolumn{3}{|c|}{ Geology } \\
\hline & & & $\begin{array}{c}\text { Distance } \\
\text { (feet) }\end{array}$ & $\mathrm{T}$ & R. & & & & $\begin{array}{l}\text { Footage and } \\
\text { depth (feet) }\end{array}$ & $\begin{array}{l}\text { Symbol } \\
\text { on pl. } 1\end{array}$ & Lithology \\
\hline
\end{tabular}

Koehn Lake area

[Locations of test holes are shown on pl. 1]

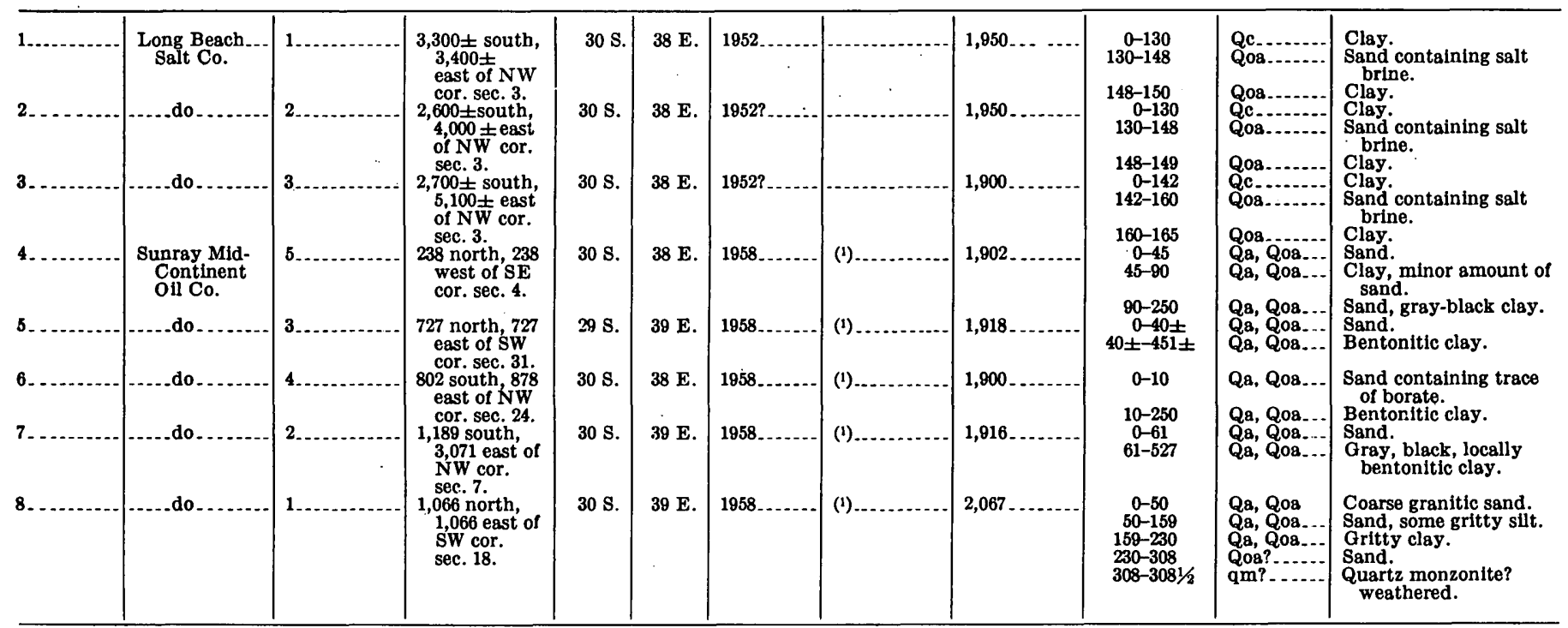

West of Kramer (Boron) borate district

[Locations of test holes are shown on fig. 48]

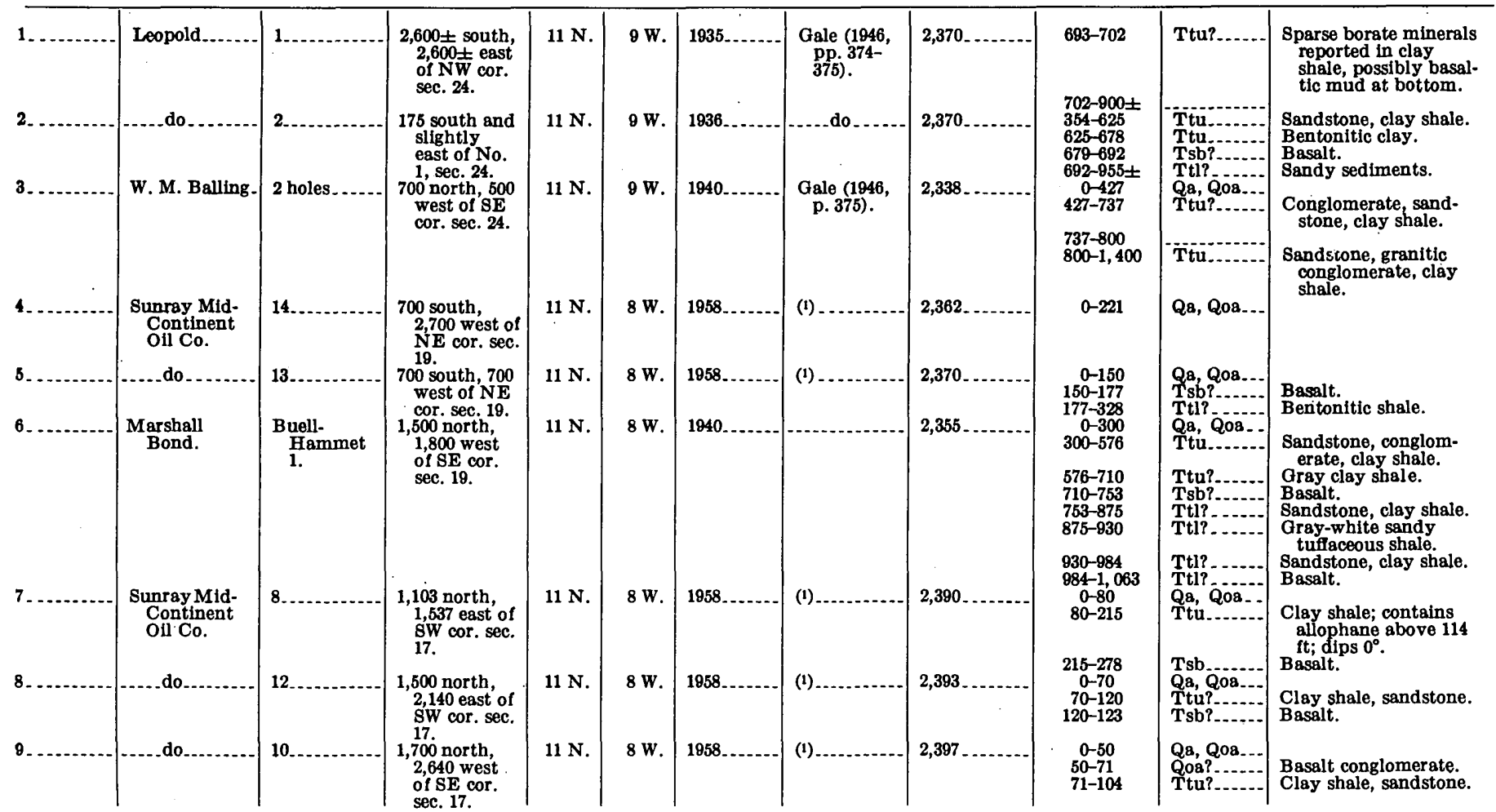

See footnotes at end of table. 
TABLE 3.-Exploratory test holes drilled for minerals in western Mojave Desert region-Continued

\begin{tabular}{|c|c|c|c|c|c|c|c|c|c|c|c|}
\hline \multirow{2}{*}{$\begin{array}{l}\text { Number } \\
\text { on maps }\end{array}$} & \multirow{2}{*}{ Operator } & \multirow{2}{*}{ Hole } & \multicolumn{3}{|c|}{ Location } & \multirow{2}{*}{$\begin{array}{l}\text { Year } \\
\text { drilled }\end{array}$} & \multirow{2}{*}{$\begin{array}{l}\text { Source of } \\
\text { data }\end{array}$} & \multirow{2}{*}{$\underset{\text { (feet) }}{\text { Altitude }}$} & \multicolumn{3}{|c|}{ Geology } \\
\hline & & & $\begin{array}{c}\text { Distance } \\
\text { (feet) }\end{array}$ & $\mathrm{T}$. & $\mathrm{R}$. & & & & $\begin{array}{l}\text { Footage and } \\
\text { depth (feet) }\end{array}$ & $\begin{array}{l}\text { Symbol } \\
\text { on pl. } 1\end{array}$ & Lithology \\
\hline
\end{tabular}

West of Kramer (Boron) borate district-Continued

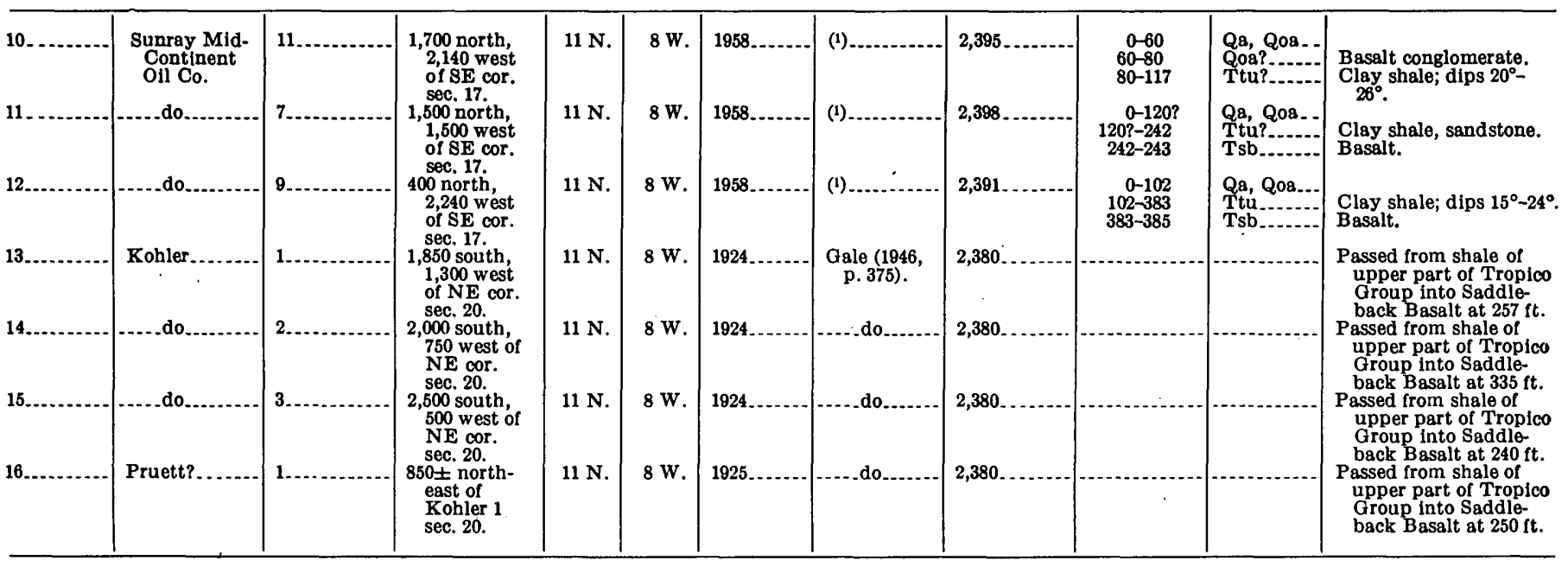

Kramer (Boron) borate district

[Locations of test holes are shown on fig. 46]

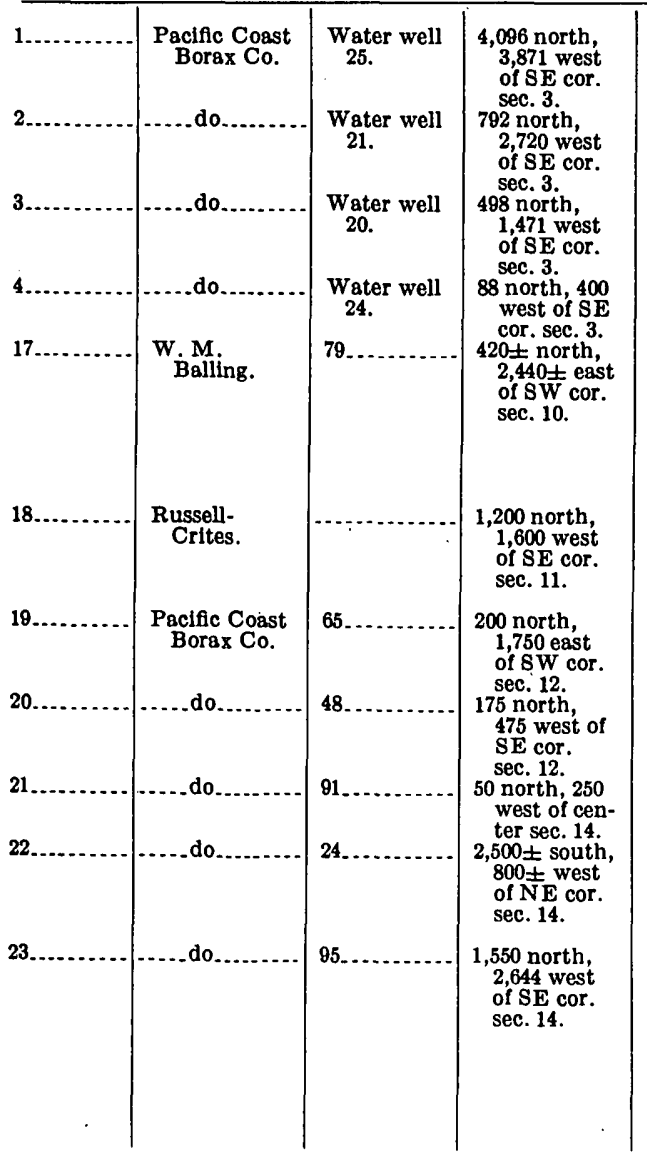

\begin{tabular}{|c|c|c|c|c|c|c|c|}
\hline $11 \mathrm{~N}$. & $8 \mathrm{w}$. & $1954 \ldots \ldots$ & (4) $\ldots . .$. & $2,482 \ldots \ldots$ & $\begin{array}{r}0-185 \\
185-449\end{array}$ & $\begin{array}{l}\text { Qa, Q0a... } \\
\text { Q0a........ }\end{array}$ & $\begin{array}{l}\text { Sand, gravel, and clay. } \\
\text { Clay, thin beds of sand } \\
\text { and gravel. }\end{array}$ \\
\hline $11 \mathrm{~N}$. & $8 \mathrm{~W}$ & $1954 \ldots$ & (4).. & $2,466 \ldots$ & $\begin{array}{r}0-197 \\
197-430\end{array}$ & $\begin{array}{l}\text { Qa, Qoa... } \\
\text { Tsb....... }\end{array}$ & $\begin{array}{l}\text { Sand, gravel, and clay. } \\
\text { Bassit. }\end{array}$ \\
\hline $11 \mathrm{~N}$. & $8 \mathrm{w}$ & $1954 .$. & (4) $\ldots$ & $2,472 \ldots$ & $\begin{array}{r}0-238 \\
238-414\end{array}$ & $\begin{array}{l}\text { Qa, Qoa } \\
\text { Tsb... }\end{array}$ & $\begin{array}{l}\text { Sand, gravel, and clay. } \\
\text { Basalt. (White tuff } \\
\text { from } 340 \text { to } 394 \text { ft). }\end{array}$ \\
\hline $11 \mathrm{~N}$. & $8 \mathrm{~W}$. & 1954. & (4) & $2,471 \ldots$ & $\begin{array}{r}0-270 \\
270-500\end{array}$ & $\begin{array}{l}\text { Qa, Qoa } \\
\text { Tsb....... }\end{array}$ & $\begin{array}{l}\text { Sand, gravel, and clay. } \\
\text { Basalt. }\end{array}$ \\
\hline $11 \mathrm{~N}$. & $8 \mathrm{~W}$ & $\begin{array}{r}\text { Before } \\
1935 .\end{array}$ & . & & $\begin{array}{l}245-330 \\
330-675 \\
675-770\end{array}$ & $\begin{array}{l}\text { Ttl?.. } \\
\text { Ttl?.- } \\
\text { Ttl?.. }\end{array}$ & $\begin{array}{l}\text { "Shale," green and blue. } \\
\text { "Granitic sediments" } \\
\text { containing thin shale } \\
\text { layers. } \\
\text { "Brown shale" con- } \\
\text { taining some granitle } \\
\text { layers. }\end{array}$ \\
\hline $11 \mathrm{~N}$. & $8 \mathrm{~W}$ & $1827 \ldots$ & $\begin{array}{l}\text { Gale (1946, } \\
\text { p. 350, } \\
\text { pi. 52). } \\
\text { Gale (1946, } \\
\text { p. } 368) .\end{array}$ & $2,500 \ldots$ & $\begin{array}{c}770-1,000 \\
0-20 \\
20-100 \pm \\
100 \pm-330 \pm \\
330 \pm-410 \pm \\
410 \pm-700 \pm \\
0-237 \\
237-260 \\
260-386\end{array}$ & 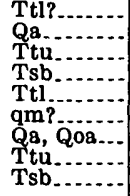 & $\begin{array}{l}\text { "Granitic sediment s." } \\
\text { Clay shale. } \\
\text { Basalt. } \\
\text { Clay shale or tuff. } \\
\text { Quartz monzonite? } \\
\text { Gravel. } \\
\text { Clay shale. } \\
\text { Basalt. }\end{array}$ \\
\hline $11 \mathrm{~N}$ & $8 \mathrm{~W}$. & 1925. & (4) & $2,535 \ldots$ & $\begin{array}{c}0-95 \\
95-450 \\
450-540\end{array}$ & $\begin{array}{l}\text { Qa, Qoa.. } \\
\text { Ttu....... } \\
\text { Ttu........ }\end{array}$ & $\begin{array}{l}\text { Clay shale. } \\
\text { Clay shale and }\end{array}$ \\
\hline $11 \mathrm{~N}$. & $8 \mathrm{w}$. & $1940 \ldots$ & (4) & $2,447 \ldots \ldots$ & $\begin{array}{c}0-63 \\
63-198\end{array}$ & Qa............ & $\begin{array}{l}\text { conglomerate. } \\
\text { Sand, gravel, clay. } \\
\text { Basalt. }\end{array}$ \\
\hline $11 \mathrm{~N}$. & $8 \mathrm{~W}$. & $\cdots$ & (4) $\ldots$ & 2,466 & 201 & & $\begin{array}{l}\text { Passed from shale of } \\
\text { upper part of Tropico } \\
\text { Group into Saddle- } \\
\text { back at bottom of } \\
\text { hole. }\end{array}$ \\
\hline $11 \mathrm{~N}$. & $8 \mathrm{~W}$. & $1940 \ldots$ & (')... & $2,450 \ldots$ & $\begin{array}{l}\begin{array}{c}0-110 ? \\
110-301 \\
301-346\end{array} \\
346-403 \\
\\
403-430 \\
430-444\end{array}$ & $\begin{array}{l}\text { Qa, Qoa... } \\
\text { Ttu?...... } \\
\text { Ttu...... } \\
\text { Ttu....... } \\
\text { Ttu....... } \\
\text { Tsb....... }\end{array}$ & $\begin{array}{l}\text { Sandstone, clay, gravel. } \\
\text { Clay shale, some sand- } \\
\text { stone, limestone, } \\
\text { bentonite. } \\
\text { Clay shale, with thin } \\
\text { layers and nodules of } \\
\text { colemanite. } \\
\text { Clay shale. } \\
\text { Basalt. }\end{array}$ \\
\hline
\end{tabular}

See footnotes at end of table. 
TABLE 3.-Exploratory test holes drilled for minerals in western Mojave Desert region-Continued

\begin{tabular}{|c|c|c|c|c|c|c|c|c|c|c|c|}
\hline \multirow{2}{*}{$\begin{array}{l}\text { Number } \\
\text { on maps }\end{array}$} & \multirow{2}{*}{ Operator } & \multirow{2}{*}{ Hole } & \multicolumn{3}{|c|}{ Location } & \multirow{2}{*}{$\begin{array}{l}\text { Year } \\
\text { drilled }\end{array}$} & \multirow{2}{*}{$\begin{array}{l}\text { Source of } \\
\text { data }\end{array}$} & \multirow{2}{*}{$\underset{\text { (feet) }}{\text { Altitude }}$} & \multicolumn{3}{|c|}{ Geology } \\
\hline & & & $\begin{array}{c}\text { Distance } \\
\text { (feet) }\end{array}$ & $\mathrm{T}$. & R. & & & & $\begin{array}{l}\text { Footage and } \\
\text { depth (feet) }\end{array}$ & $\begin{array}{l}\text { Symbol } \\
\text { on pl. } 1\end{array}$ & Lithology \\
\hline
\end{tabular}

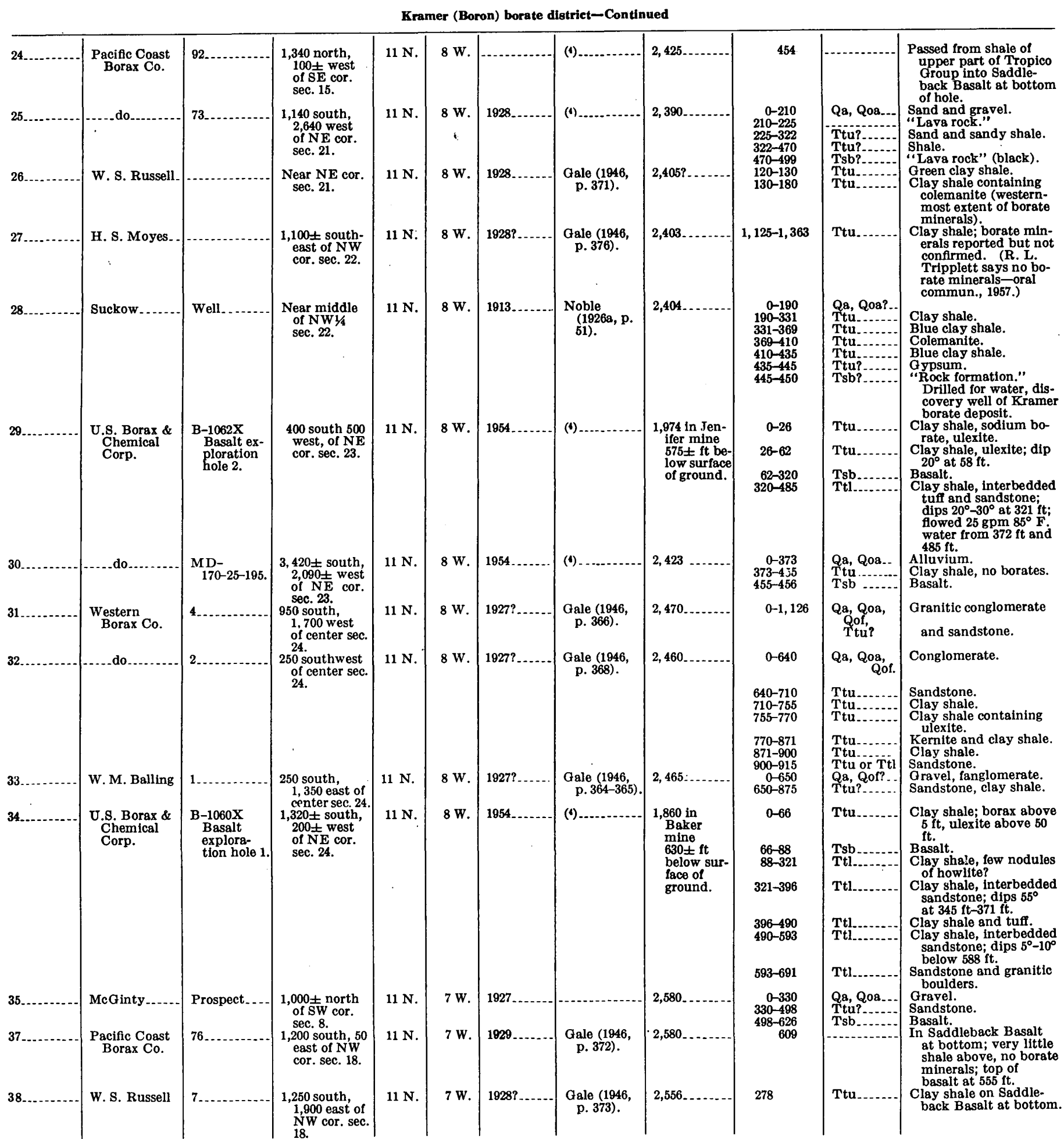

See footnotes at end of table. 
TABLES

TABLE 3.-Exploratory test holes drilled for minerals in western Mojave Desert region-Continued

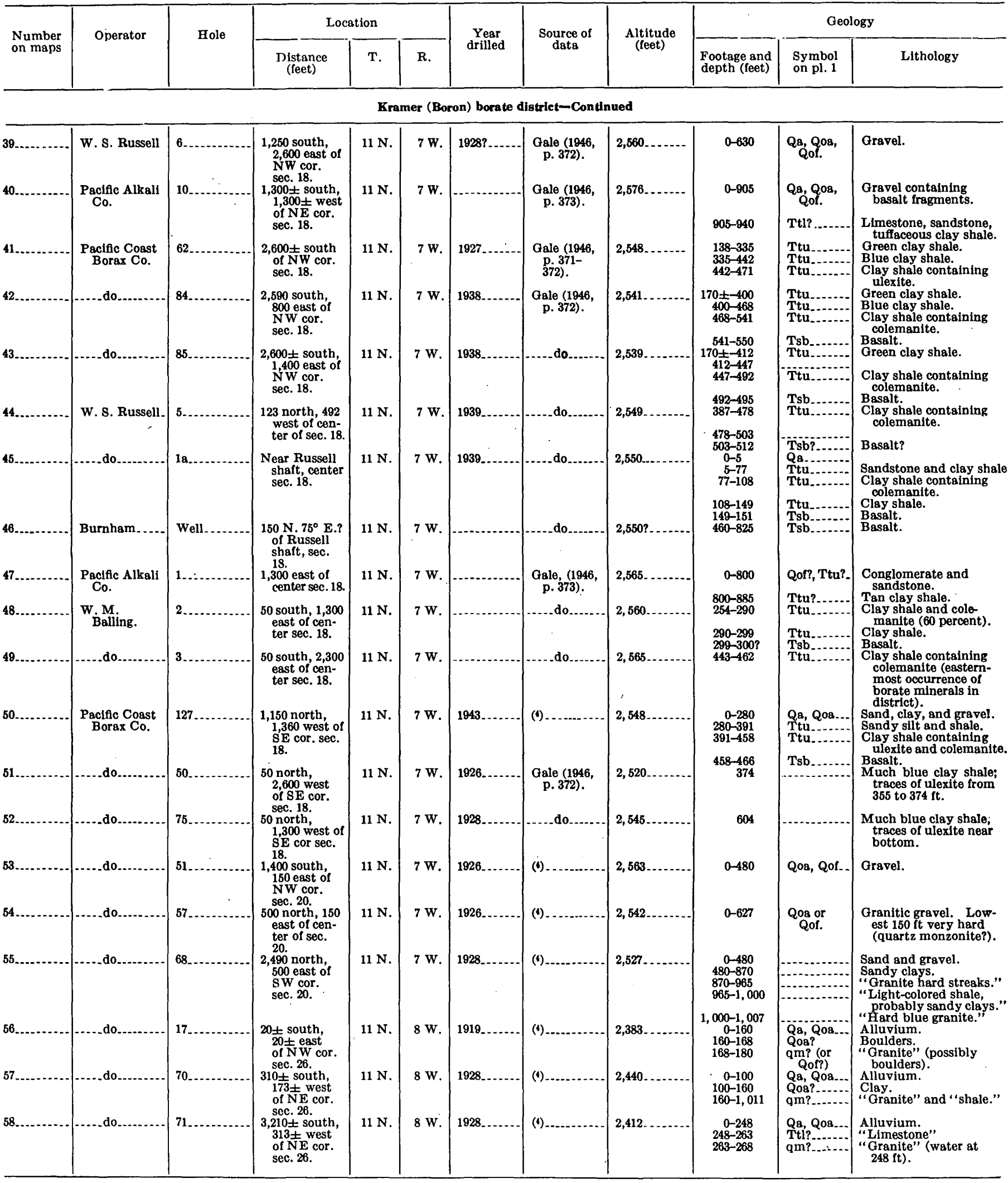

See footnotes at end of table. 
TABLE 3.-Exploratory test holes drilled for minerals in western Mojave Desert region-Continued

\begin{tabular}{|c|c|c|c|c|c|c|c|c|c|c|c|}
\hline \multirow{2}{*}{$\begin{array}{l}\text { Number } \\
\text { on maps }\end{array}$} & \multirow{2}{*}{ Operator } & \multirow{2}{*}{ Hole } & \multicolumn{3}{|c|}{ Location } & \multirow{2}{*}{$\begin{array}{l}\text { Year } \\
\text { drilled }\end{array}$} & \multirow{2}{*}{$\begin{array}{l}\text { Source of } \\
\text { data }\end{array}$} & \multirow{2}{*}{$\underset{\text { (feet) }}{\text { Altitude }}$} & \multicolumn{3}{|c|}{ Geology } \\
\hline & & & $\begin{array}{l}\text { Distance } \\
\text { (feet) }\end{array}$ & T. & $\mathbf{R}$. & & & & $\begin{array}{l}\text { Footage and } \\
\text { depth (feet) }\end{array}$ & $\begin{array}{l}\text { Symbol } \\
\text { on pl. } 1\end{array}$ & Lithology \\
\hline \multicolumn{12}{|c|}{$\begin{array}{l}\text { South of Kramer (Boron) borate district } \\
\text { [Locations of test holes are shown on pl. 1] }\end{array}$} \\
\hline & $\begin{array}{l}\text { Sunray Mid- } \\
\text { Continent } \\
\text { Oil Co. }\end{array}$ & $16 \ldots . .$. & $\begin{array}{l}1,200 \text { north, } \\
1,200 \text { east } \\
\text { of } \$ \text { w cor. }\end{array}$ & $10 \mathrm{~N}$ & $8 \mathrm{~W}$. & & (1)................. & 2,466 & $0-352$ & Qa, Q0a & Sand. \\
\hline $10 \ldots$ & .................... & 17 & $\begin{array}{l}\text { sec. } 1 \text {. } \\
2,000 \text { south, } \\
2,400 \text { east } \\
\text { of } \mathrm{NW} \text { cor. }\end{array}$ & $10 \mathrm{~N}$. & $8 \mathrm{~W}$. & - & (1) & $2,460 \ldots \ldots$ & $0-352$ & Qa, Qoa... & Sand. \\
\hline $11 \ldots . . . . .$. & $\begin{array}{l}\text { U.S. Geologi- } \\
\text { cal Survey. }\end{array}$ & $\begin{array}{l}\text { Four Cor- } \\
\text { ners } 2 .\end{array}$ & $\begin{array}{l}500 \text { south, } \\
2,640 \text { east } \\
\text { of } \mathrm{NW} \text { cor. } \\
\text { sec. } 5 \text {. }\end{array}$ & $10 \mathrm{~N}$ & $8 \mathrm{~W}$. & $1955,1957$. & $\begin{array}{l}\text { Benda, } \\
\text { Erd, and } \\
\text { Smith } \\
\text { (1960, p. } \\
\text { 328); } \\
\text { Dibblee } \\
\text { (1960d, } \\
\text { p. 135). }\end{array}$ & $2,330 \ldots \ldots$ & $\begin{array}{c}0-100 \\
100-536 \\
536-1,202 \\
1,202-1,679 \\
1,679-1,913 \\
1,913-2,328\end{array}$ & $\begin{array}{l}\text { Qa } \\
\text { Qoa............ } \\
\text { Qoa? } \\
\text { Ttu?........... }\end{array}$ & $\begin{array}{l}\text { Sand. } \\
\text { Clay and silt. } \\
\text { Sand, minor amounts } \\
\text { of clay, silt, pebbles, } \\
\text { gravel. } \\
\text { Gravel of granitic and } \\
\text { volcanic pebbles, } \\
\text { some sand and silt. } \\
\text { Sand, sandstone minor } \\
\text { amounts of clay and } \\
\text { silt; dips } 15^{\circ}-20^{\circ} \text {. } \\
\text { Sandstone; contains } \\
\text { some granitic cobbles, } \\
\text { and minor shale; } \\
\text { dips } 15^{\circ}-30^{\circ} \text {. }\end{array}$ \\
\hline
\end{tabular}

East Kramer borate district

[Locations of test holes are shown on fig. 49]

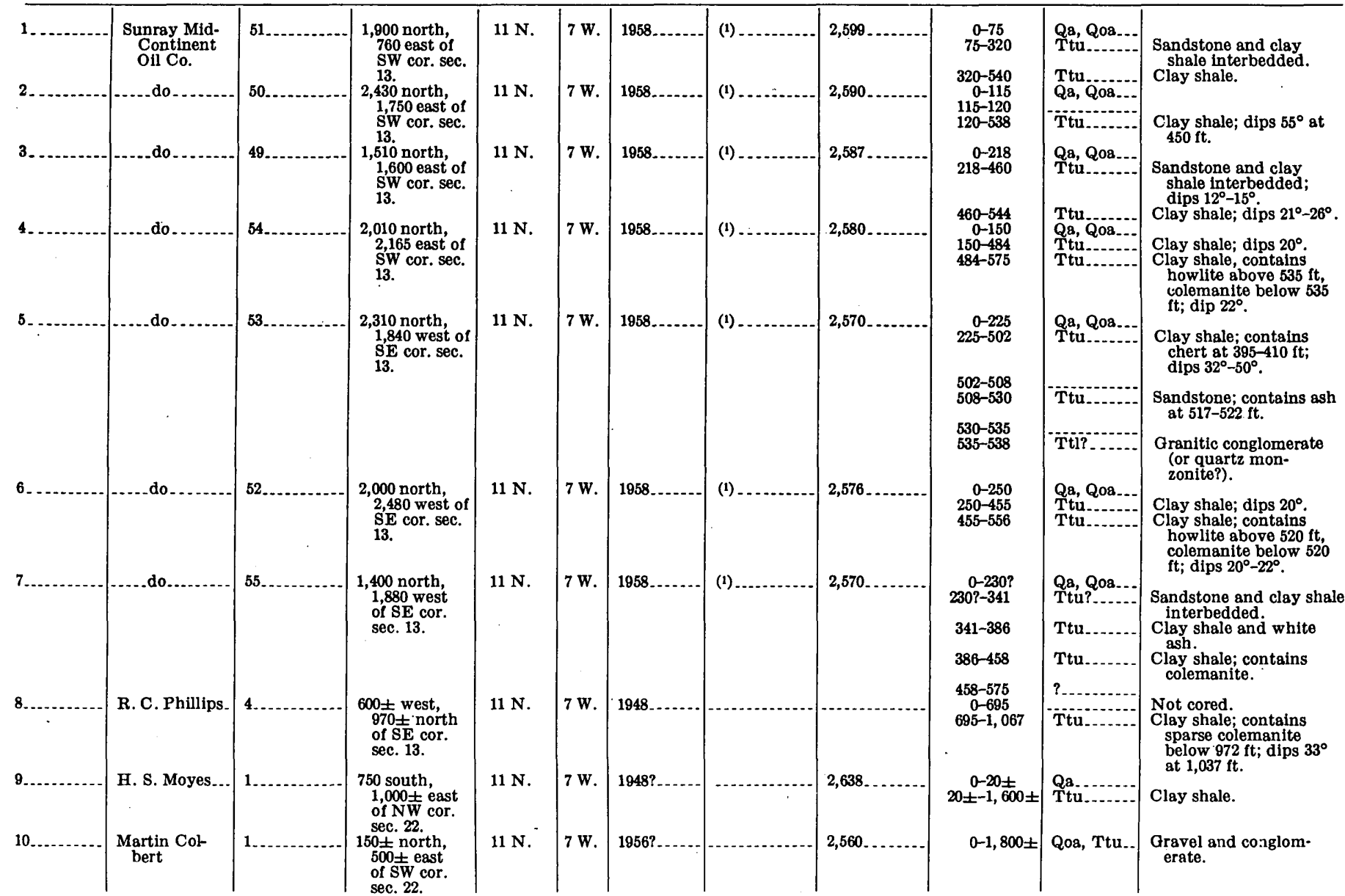

See footnotes at end of table. 
TABLES

TABLE 3.-Exploratory test holes drilled for minerals in western Mojave Desert region-Continued

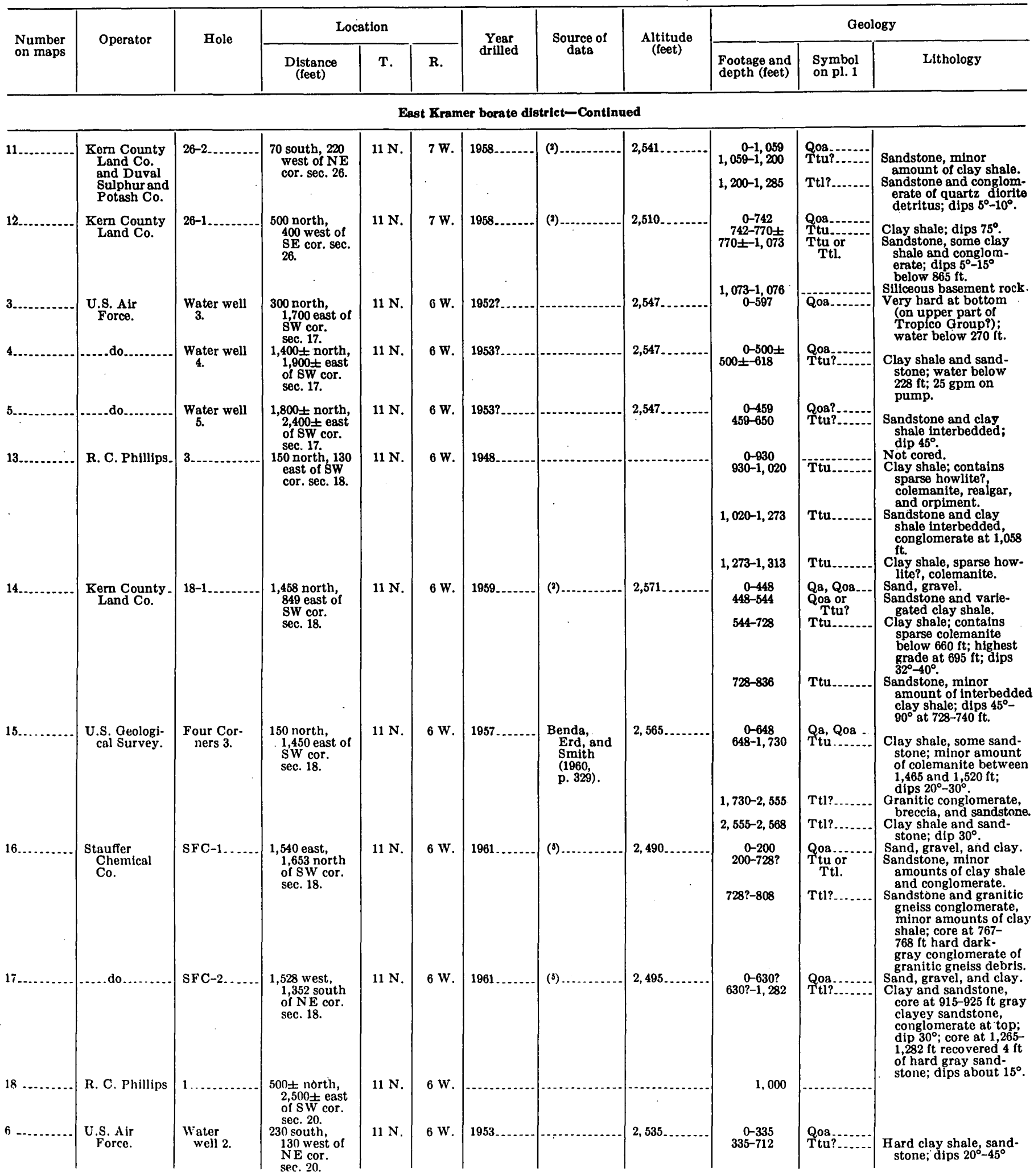

See footnotes at end of table. 
TABLE 3.-Exploratory test holes drilled for minerals in western Mojave Desert region-Continued

\begin{tabular}{|c|c|c|c|c|c|c|c|c|c|c|c|}
\hline \multirow{2}{*}{$\begin{array}{l}\text { Number } \\
\text { on maps }\end{array}$} & \multirow{2}{*}{ Operator } & \multirow{2}{*}{ Hole } & \multicolumn{3}{|c|}{ Location } & \multirow{2}{*}{$\begin{array}{l}\text { Year } \\
\text { drilled }\end{array}$} & \multirow{2}{*}{$\begin{array}{c}\text { Source of } \\
\text { data }\end{array}$} & \multirow{2}{*}{$\begin{array}{c}\text { Altitude } \\
\text { (feet) }\end{array}$} & \multicolumn{3}{|c|}{ Geology } \\
\hline & & & $\begin{array}{c}\text { Distance } \\
\text { (feet) }\end{array}$ & $\mathrm{T}$. & R. & & & & $\begin{array}{l}\text { Footage and } \\
\text { depth (feet) }\end{array}$ & $\begin{array}{l}\text { Symbol } \\
\text { on pl. } 1\end{array}$ & Lithology \\
\hline
\end{tabular}

East Kramer borate district-Continued

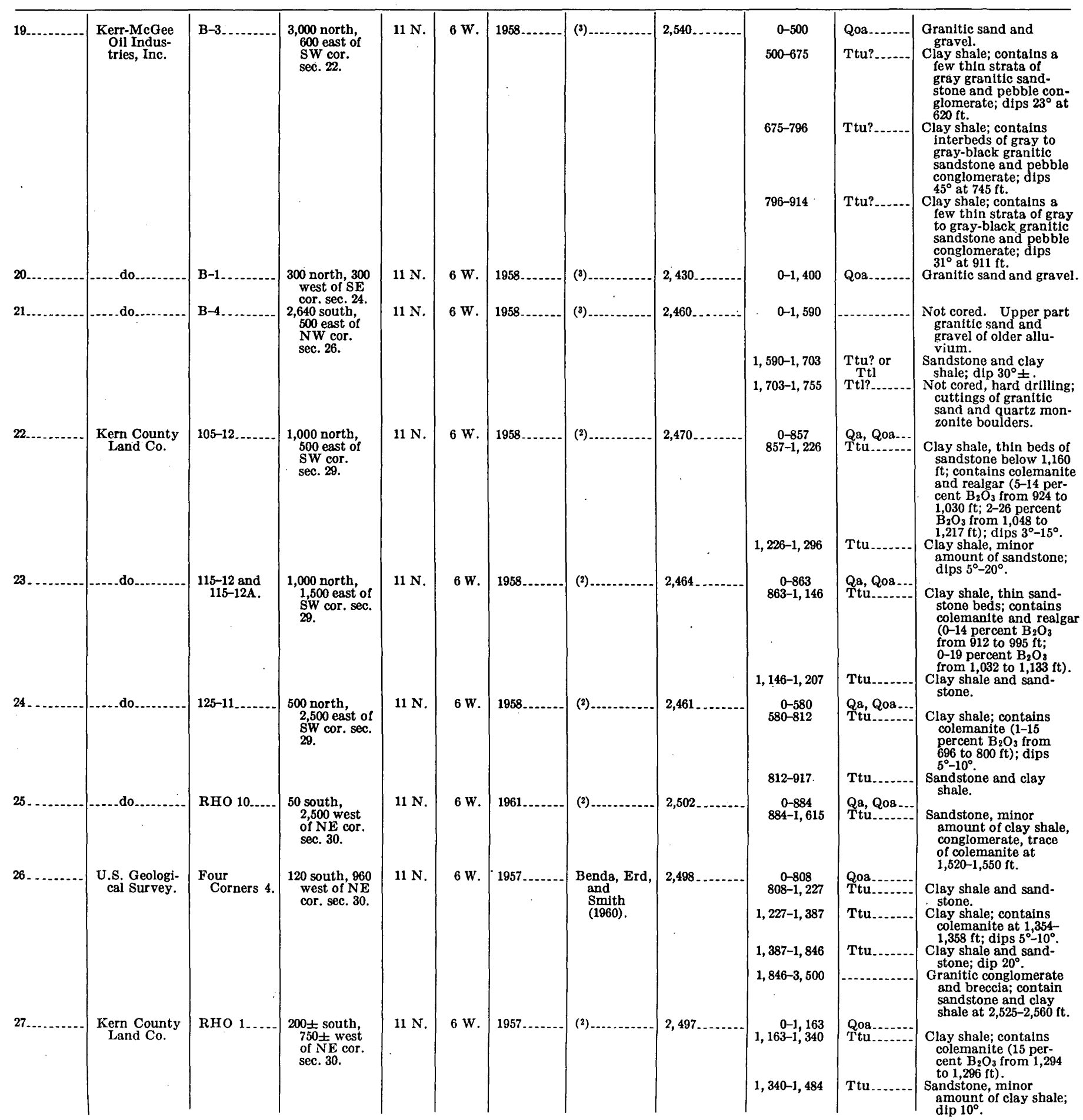

See footnotes at end of table. 
TABLES

TABLE 3.-Exploratory test holes drilled for minerals in western Mojave Desert region-Continued

\begin{tabular}{|c|c|c|c|c|c|c|c|c|c|c|c|}
\hline \multirow{2}{*}{$\begin{array}{l}\text { Number } \\
\text { on maps }\end{array}$} & \multirow{2}{*}{ Operator } & \multirow{2}{*}{ Hole } & \multicolumn{3}{|c|}{ Location } & \multirow{2}{*}{$\begin{array}{c}\text { Year } \\
\text { drilled }\end{array}$} & \multirow{2}{*}{$\begin{array}{l}\text { Source of } \\
\text { data }\end{array}$} & \multirow{2}{*}{$\begin{array}{c}\text { Altitude } \\
\text { (feet) }\end{array}$} & \multicolumn{3}{|c|}{ Geology } \\
\hline & & & $\begin{array}{c}\text { Distance } \\
\text { (feet) }\end{array}$ & $\mathrm{T}$. & R. & & & & $\begin{array}{l}\text { Footage and } \\
\text { depth (feet) }\end{array}$ & $\begin{array}{l}\text { Symbol } \\
\text { on pl. } 1\end{array}$ & Lithology \\
\hline
\end{tabular}

East Kramer borate district-Continued

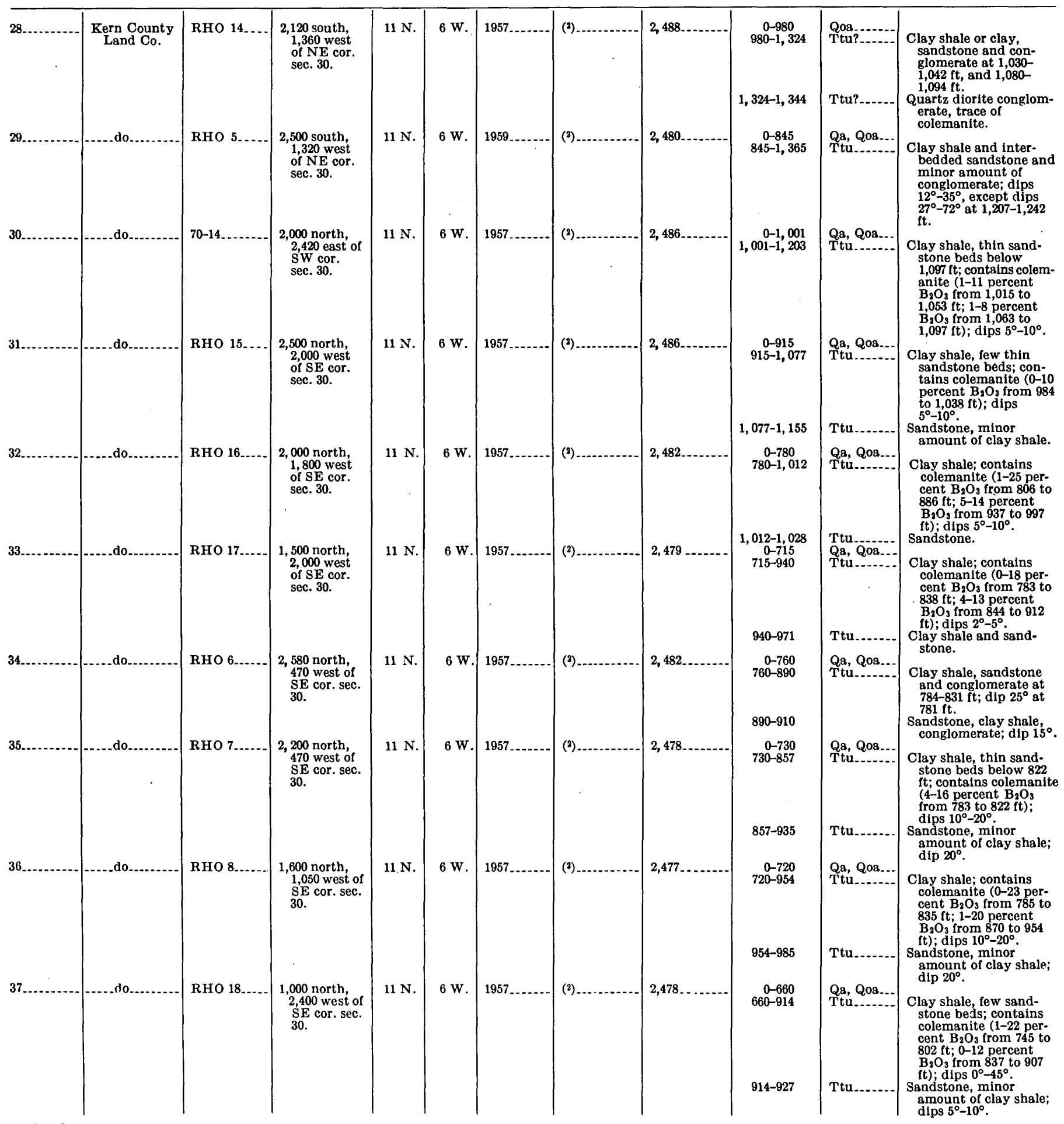

See footnotes at end of table. 
TABLE 3.-Exploratory test holes drilled for minerals in western Mojave Desert region-Continued

\begin{tabular}{|c|c|c|c|c|c|c|c|c|c|c|c|}
\hline \multirow{2}{*}{$\begin{array}{l}\text { Number } \\
\text { on maps }\end{array}$} & \multirow{2}{*}{ Operator } & \multirow{2}{*}{ Hole } & \multicolumn{3}{|c|}{ Location } & \multirow{2}{*}{$\begin{array}{l}\text { Year } \\
\text { drilled }\end{array}$} & \multirow{2}{*}{$\begin{array}{l}\text { Source of } \\
\text { data }\end{array}$} & \multirow{2}{*}{$\underset{\text { (feet) }}{\text { Altitude }}$} & \multicolumn{3}{|c|}{ Geology } \\
\hline & & & $\begin{array}{c}\text { Distance } \\
\text { (feet) }\end{array}$ & $\mathbf{T}$ & R. & & & & $\begin{array}{l}\text { Footage and } \\
\text { depth (feet) }\end{array}$ & $\begin{array}{l}\text { Symbol } \\
\text { on pl. } 1\end{array}$ & Lithology \\
\hline
\end{tabular}

Fast Kramer borate district-Continued

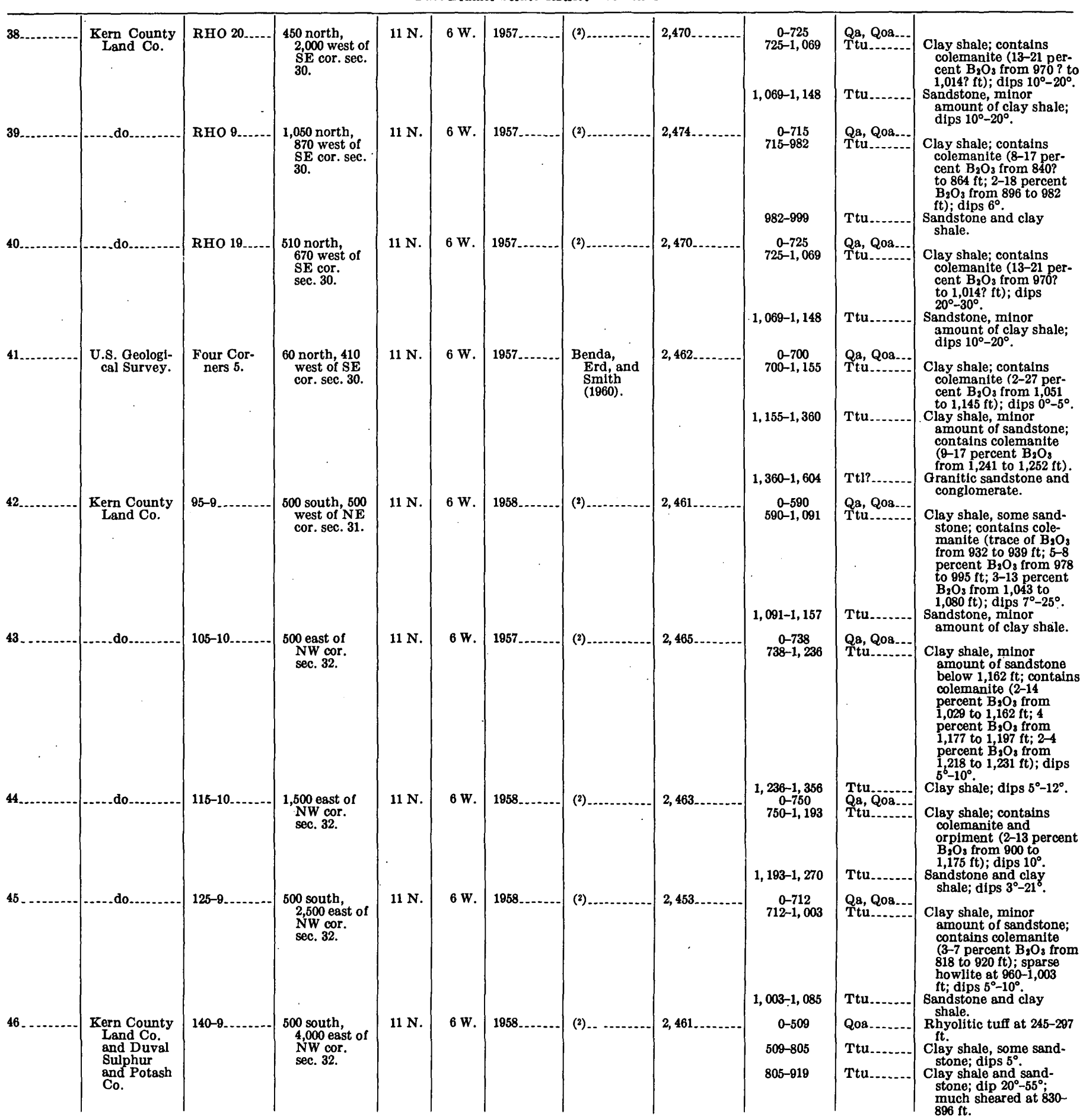

See footnotes at end of table. 
TABLES

TABLE 3.-Exploratory test holes drilled for minerals in western Mojave Desert region-Continued

\begin{tabular}{|c|c|c|c|c|c|c|c|c|c|c|c|}
\hline \multirow{2}{*}{$\begin{array}{l}\text { Number } \\
\text { on maps }\end{array}$} & \multirow{2}{*}{ Operator } & \multirow{2}{*}{ Hole } & \multicolumn{3}{|c|}{ Location } & \multirow{2}{*}{$\underset{\text { drilled }}{\text { Year }}$} & \multirow{2}{*}{$\begin{array}{l}\text { Source of } \\
\text { data }\end{array}$} & \multirow{2}{*}{$\underset{\text { (feet) }}{\text { Altitude }}$} & \multicolumn{3}{|c|}{ Geology } \\
\hline & & & $\begin{array}{c}\text { Distance } \\
\text { (feet) }\end{array}$ & $T$. & $\mathbf{R}$ & & & & $\begin{array}{l}\text { Footage and } \\
\text { depth (feet) }\end{array}$ & $\begin{array}{l}\text { Symbol } \\
\text { on pl. } 1\end{array}$ & Lithology \\
\hline
\end{tabular}

East Kramer borate district-Continued

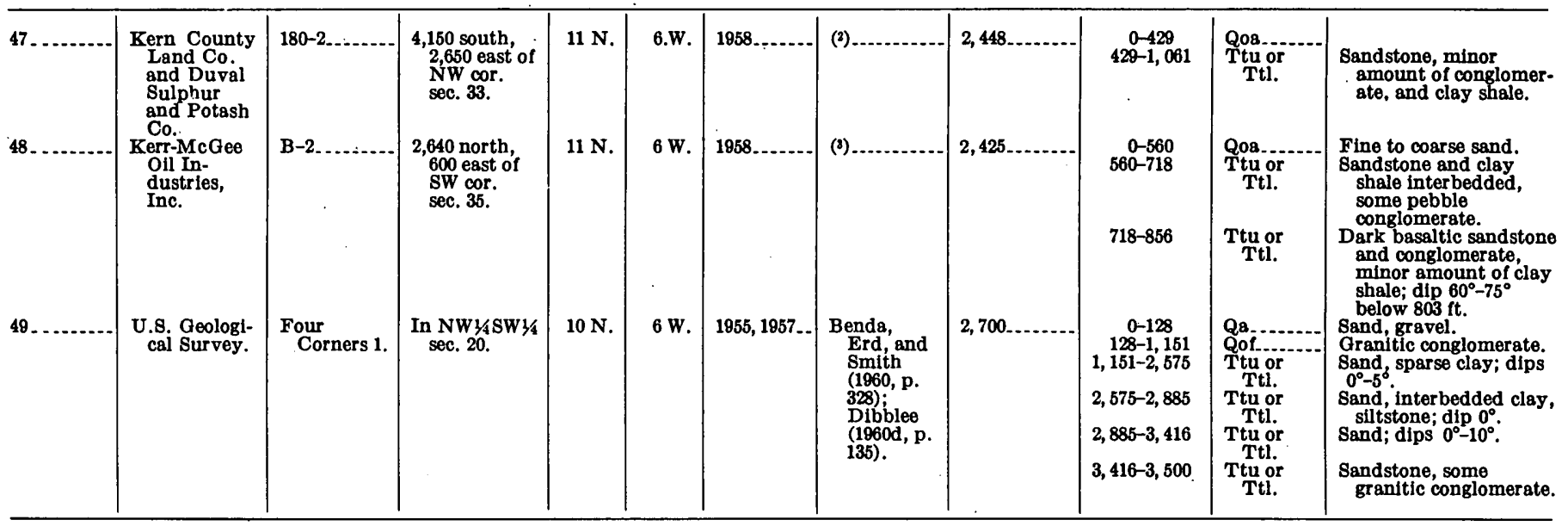

Harper Lake area

[Locations of test holes are shown on p]. 1]

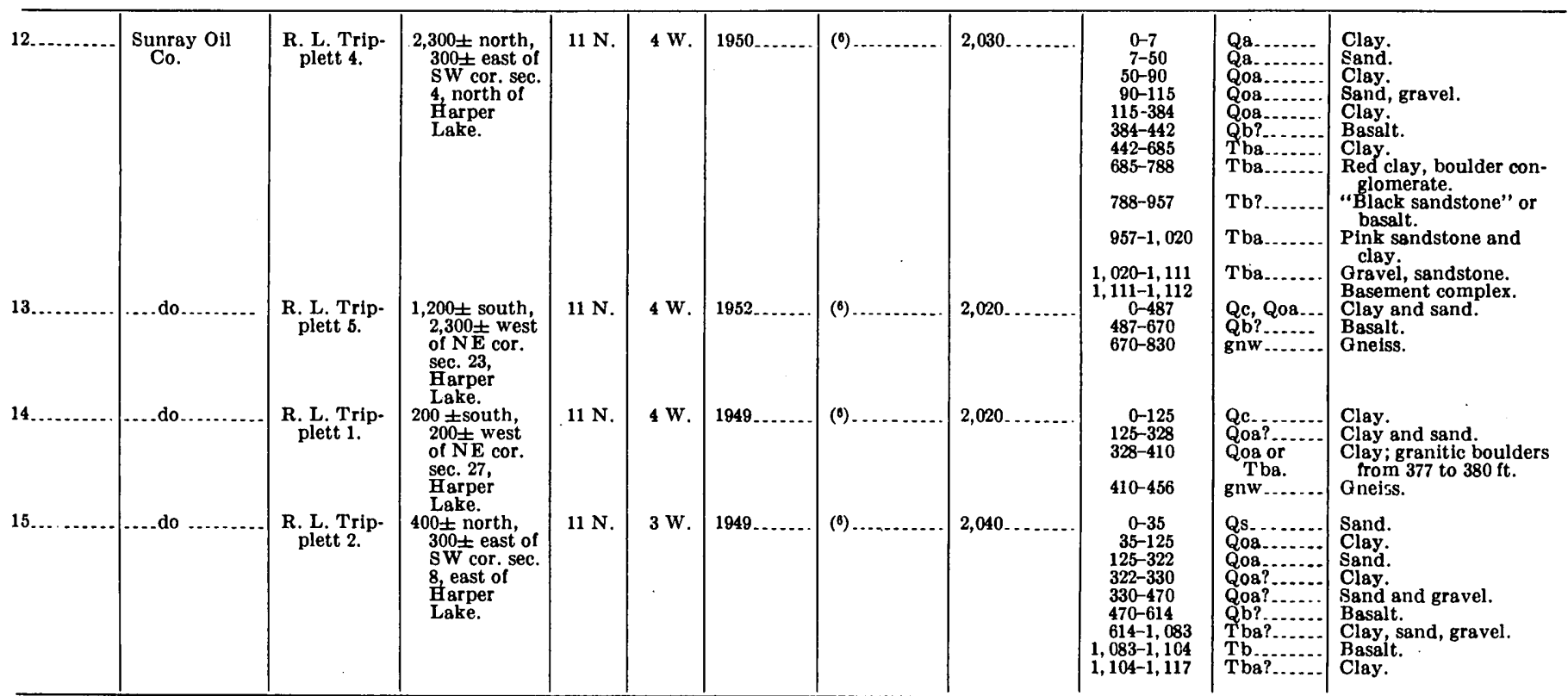

1 Furnished by, and published with permission of, the Sunray Mid-Continent OIl Co.

Furnished by, and published with permission of the Kern County Land Co. 3 Furnished by, and published with permission of, the Kerr-McGee Oil Industries,
Inc.

4 Published with permission of the Pacific Coast Borax Co., Division of U.S. Borax and Chemical Co.

Furnished by, and published with permission of, Stauffer Chemical Co.

- Furnished by, and published with permission of, $\mathbf{R}$. L. Tripplett. 
TABLE 4.-Exploratory test wells drilled for oil and gas, and geologically significant water wells, in western Mojave Desert region

[Oil or gas is not known to have been found in any test well in this region. All test wells have been abandoned or suspended, except a few which were converted to water wells Test wells are listed by arcas, townships, and sections generally from north to south and west to east. The test wells for which accurate locations are known are shown on pl. 1; water well indicated in first column by prefix w; oll or gas test well by prefix o]

\begin{tabular}{|c|c|c|c|c|c|c|c|c|c|c|c|}
\hline \multirow[b]{2}{*}{ No. (pl. 1) } & \multirow{2}{*}{$\begin{array}{l}\text { Operator or } \\
\text { owner }\end{array}$} & \multirow[b]{2}{*}{ Well } & \multicolumn{3}{|c|}{ Location } & \multirow[b]{2}{*}{ Year drilled } & \multirow[b]{2}{*}{ Source of data } & \multirow{2}{*}{$\underset{\text { (feet) }}{\text { Altitude }}$} & \multicolumn{3}{|c|}{ Geology } \\
\hline & & & $\begin{array}{l}\text { Approximate } \\
\text { distance (feet) }\end{array}$ & $\mathbf{T}$. & $\mathbf{R}$. & & & & $\begin{array}{l}\text { Footage and } \\
\text { depth (feet) }\end{array}$ & $\begin{array}{c}\text { Symbol } \\
\text { (pl. 1) }\end{array}$ & Lithology \\
\hline
\end{tabular}

Area east of Johannesburg

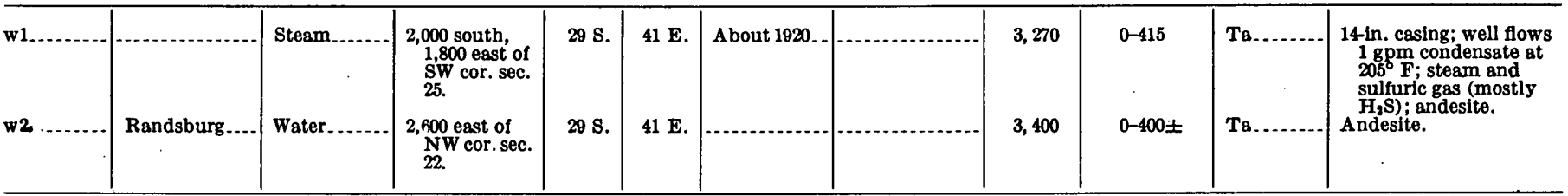

Cantil area

\begin{tabular}{|c|c|c|c|}
\hline 01 & $\begin{array}{c}\text { Redrock Can- } \\
\text { yon Oil Co. }\end{array}$ & & $\begin{array}{l}2,000 \text { south, } \\
100 \text { east of } \\
\mathrm{NW} \text { cor. } \\
\text { sec. } 13 .\end{array}$ \\
\hline $02 \ldots \ldots \ldots$ & $\begin{array}{l}\text { Western } \\
\text { Research } \\
\text { Lab., Inc. }\end{array}$ & $\begin{array}{c}\text { Cruick- } \\
\text { shank } \\
\text { A-1. }\end{array}$ & $\begin{array}{l}2,500 \text { south, } \\
1,500 \text { east of } \\
\text { NW cor. } \\
\text { sec. } 13 .\end{array}$ \\
\hline $03 \ldots$ & $\begin{array}{l}\text { Crown Drill- } \\
\text { ing Co. }\end{array}$ & $\begin{array}{l}\text { Rancho } \\
\text { Rico } 1 . \\
\text { Water....... }\end{array}$ & $\begin{array}{l}900 \pm \text { north, } \\
1,200 \pm \text { east } \\
\text { of } \mathrm{SW} \text { cor. } \\
\text { sec. } 27 \text {. } \\
900 \pm \text { north, } \\
600 \pm \text { east of } \\
\text { SW cor. } \\
\text { sec. } 36 \text {. }\end{array}$ \\
\hline $04 \ldots$ & & - & $\begin{array}{l}700 \pm \text { south, } \\
100 \pm \text { west } \\
\text { of NE cor. } \\
\text { sec. } 19 .\end{array}$ \\
\hline $05 \ldots$ & $\begin{array}{l}\mathrm{J} \text { and } \mathrm{S} E x- \\
\text { ploration } \\
\text { Co. }\end{array}$ & $\begin{array}{l}\text { Cruick- } \\
\text { shank } 2 .\end{array}$ & $\begin{array}{l}2,500 \pm \text { south, } \\
2,250 \pm \text { east } \\
\text { of } N W \text { cor. } \\
\text { sec. } 19 .\end{array}$ \\
\hline o6..... & ....do............ & $\begin{array}{l}\text { Cruick- } \\
\text { shank } 3 .\end{array}$ & $\begin{array}{l}500 \pm \text { north, } \\
1,700 \pm \text { east } \\
\text { of } \$ W \text { cor. } \\
\text { sec. } 19 .\end{array}$ \\
\hline $07 \ldots$ & $\begin{array}{l}\text { Red Rock Oil } \\
\text { Co. }\end{array}$ & $\begin{array}{l}\text { C. W. Har- } \\
\text { low? } 1\end{array}$ & $\begin{array}{l}200 \pm \text { north, } \\
2,700 \pm \text { east } \\
\text { of SW cor. } \\
\text { sec. } 19 .\end{array}$ \\
\hline w4 $\ldots . .$. & $\ldots$ & Water....... & $\begin{array}{l}500 \pm \text { north, } \\
2,400 \pm \text { east } \\
\text { of } \mathrm{SW} \text { cor. } \\
\text { sec. } 2 \text {. }\end{array}$ \\
\hline
\end{tabular}

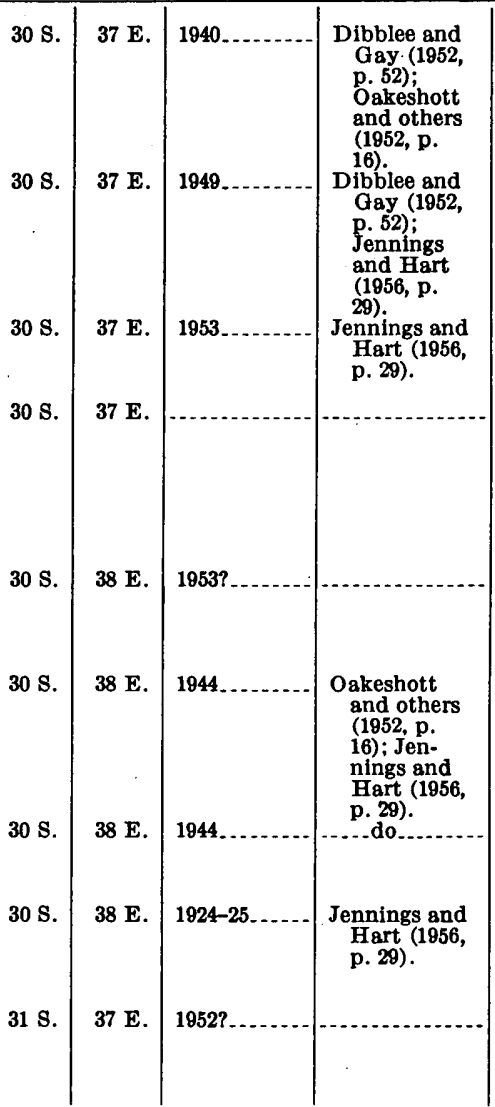

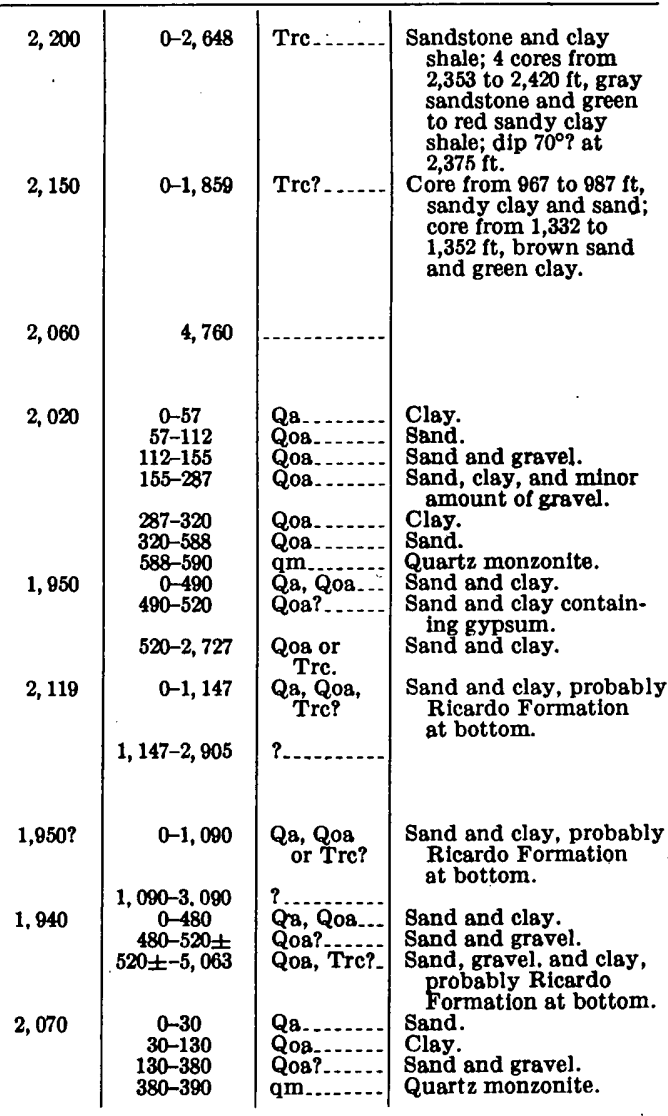

Mojave, Castle Butte and north of Boron area

\begin{tabular}{|c|c|c|c|}
\hline w5 & $\begin{array}{c}\text { N. K. Men- } \\
\text { delsohn. }\end{array}$ & $\begin{array}{l}\text { Water test } \\
\text { 2. }\end{array}$ & $\begin{array}{l}1,000 \pm \text { north, } \\
1,500 \pm \text { east } \\
\text { of } \mathrm{SW} \text { cor. } \\
\text { sec. } 24 \text {. }\end{array}$ \\
\hline w6......... & ......do do & Water test 1 & $\begin{array}{l}1,500 \pm \text { east of } \\
\text { SW cor. } \\
\text { sec. } 24 .\end{array}$ \\
\hline $08 \ldots$ & S. Chevalier & Chevalier... & $\begin{array}{l}500 \pm \text { north, } \\
1,200 \pm \text { east } \\
\text { of } \mathrm{SW} \text { cor. } \\
\text { sec. } 35 .\end{array}$ \\
\hline w7 ......... & $\underset{\text { Cement Co. }}{\text { Monolith }}$ & Water. & $\begin{array}{l}2,100 \pm \text { north, } \\
100 \pm \text { west } \\
\text { of SE cor. } \\
\text { sec. } 15 \text {. }\end{array}$ \\
\hline
\end{tabular}

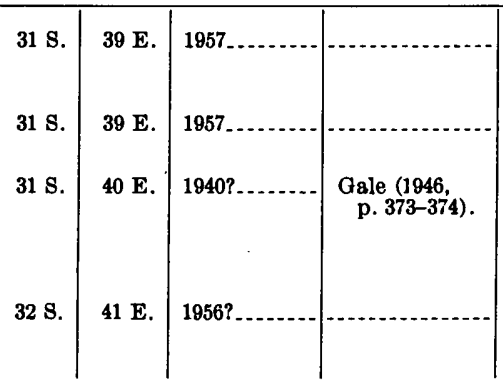

2,920

\begin{tabular}{|c|c|c|}
\hline $0-1,300$ & Qoa........ & Granitic sand. \\
\hline $0-840$ & qd. . & Quartz diorite. \\
\hline $\begin{array}{r}0-700 \pm \\
700 \pm-1,600 \\
1,000-1,260\end{array}$ & $\begin{array}{l}\text { Qoa....... } \\
\text { Qoa? } \\
\text { Qoa? }\end{array}$ & $\begin{array}{l}\text { Sand. } \\
\text { Sand, white ash? beds. } \\
\text { Red sandstone and }\end{array}$ \\
\hline $1,260-1,750$ & Qoa? & $\begin{array}{l}\text { green clay. } \\
\text { Green clay and arkosic }\end{array}$ \\
\hline $0-300 ?$ & & $\begin{array}{l}\text { sanastone. } \\
\text { Granitic sand. }\end{array}$ \\
\hline
\end{tabular}


TABLE 4.-Exploratory test wells drilled for oil and gas, and geologically significant water wells, in western Mojave Desert region-Con.

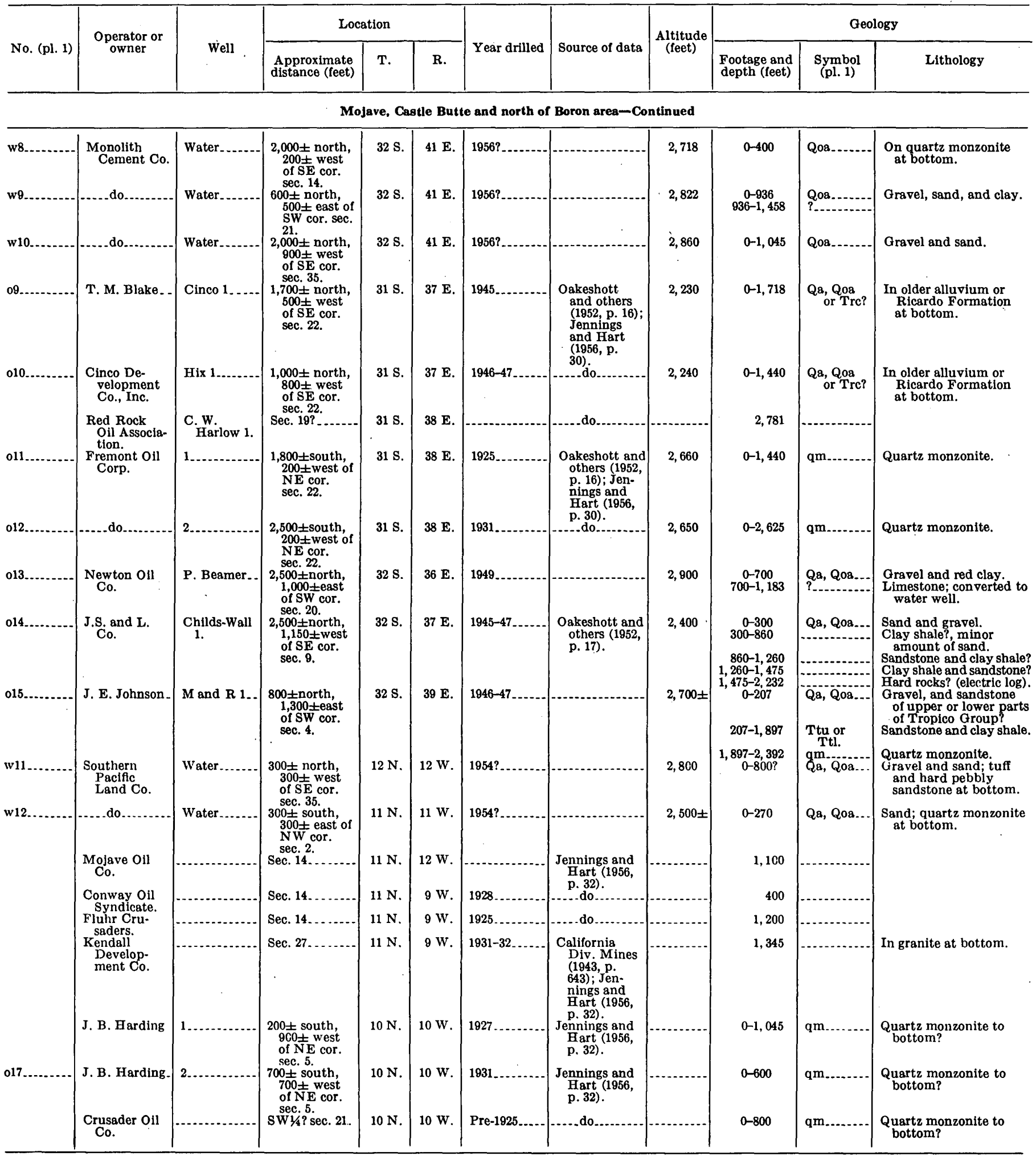


TABLE 4.-Exploratory test wells drilled for oil and gas, and geologically significant water wells, in western Mojave Desert region-Con.

\begin{tabular}{|c|c|c|c|c|c|c|c|c|c|c|c|}
\hline \multirow{2}{*}{ No. (pl. 1) } & \multirow{2}{*}{$\begin{array}{l}\text { Operator or } \\
\text { owner }\end{array}$} & \multirow{2}{*}{ Well } & \multicolumn{3}{|c|}{ Location } & \multirow{2}{*}{ Year drilled } & \multirow{2}{*}{ Source of data } & \multirow{2}{*}{$\underset{\text { (feet) }}{\text { Altitude }}$} & \multicolumn{3}{|c|}{ Geology } \\
\hline & & & $\begin{array}{r}\text { Approximate } \\
\text { distance (feet) }\end{array}$ & T. & R. & & & & $\begin{array}{l}\text { Footage and } \\
\text { depth (feet) }\end{array}$ & $\begin{array}{c}\text { Symbol } \\
\text { (pl. 1) }\end{array}$ & Lithology \\
\hline
\end{tabular}

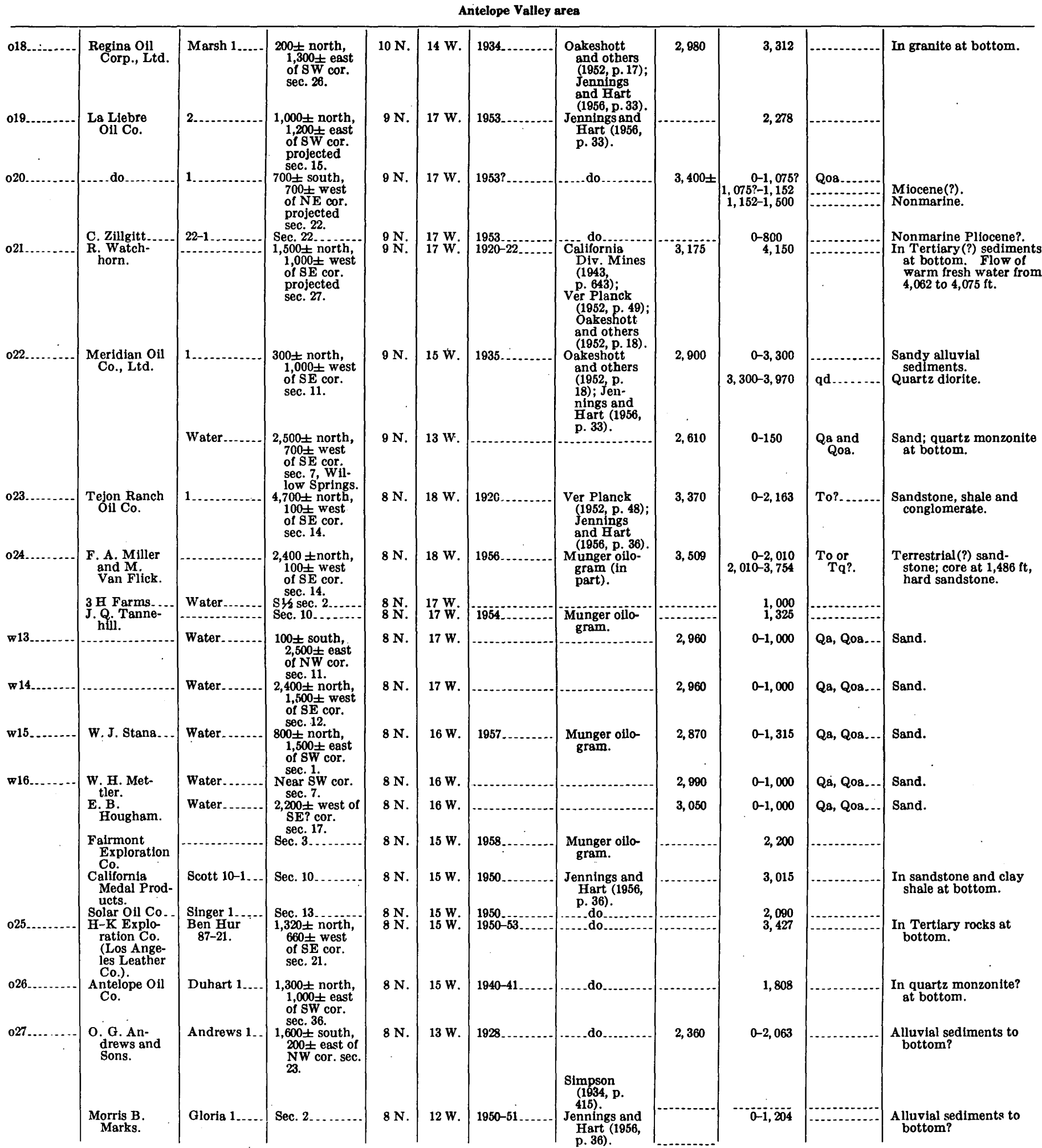


TABLE 4.-Exploratory test wells drilled for oil and gas, and geologically significant water wells, in western Mojave Desert region-Con.

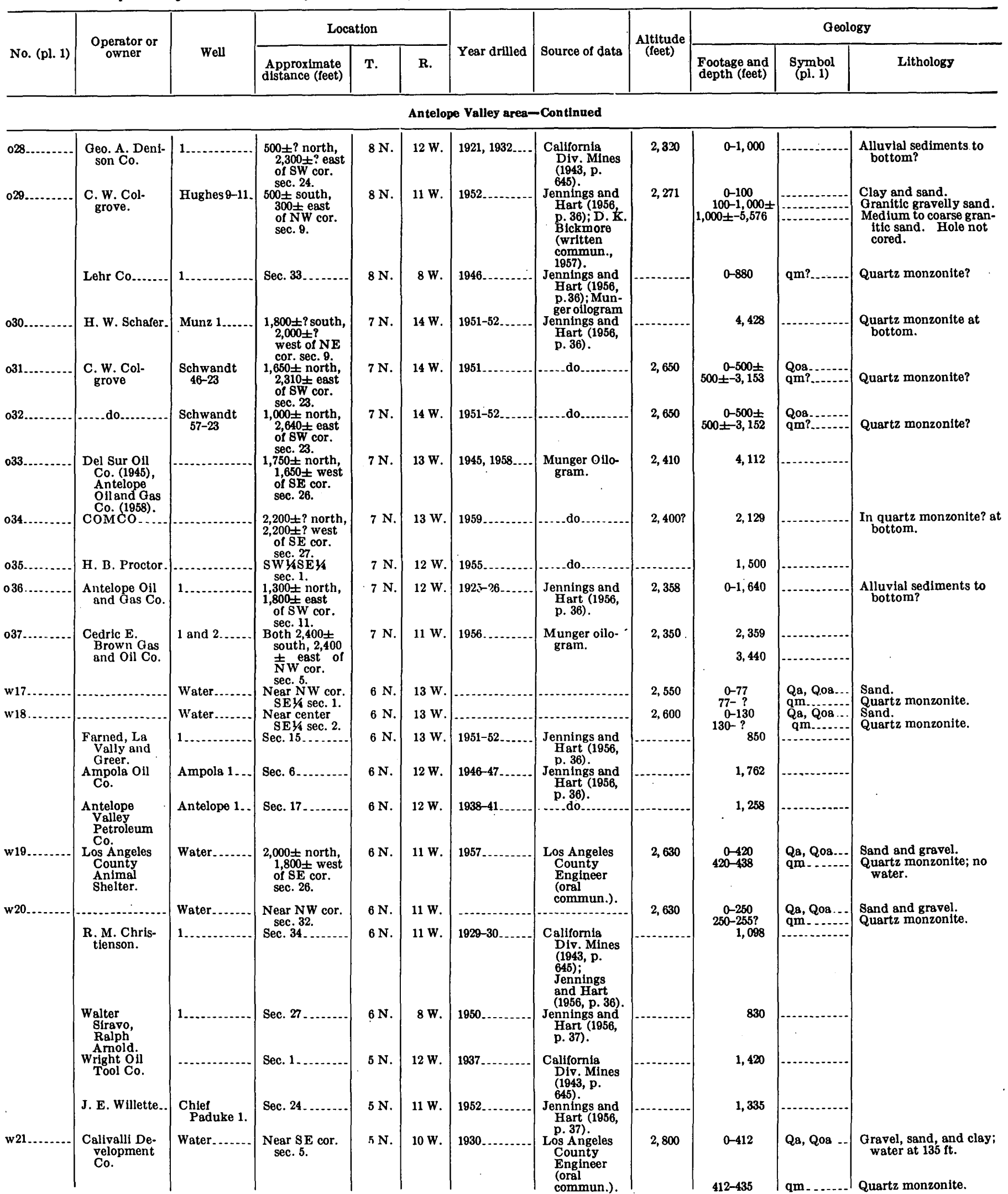


TABLE 4.-Exploratory test wells drilled for oil and gas, and geologically significant water wells, in western Mojave Desert region-Con.

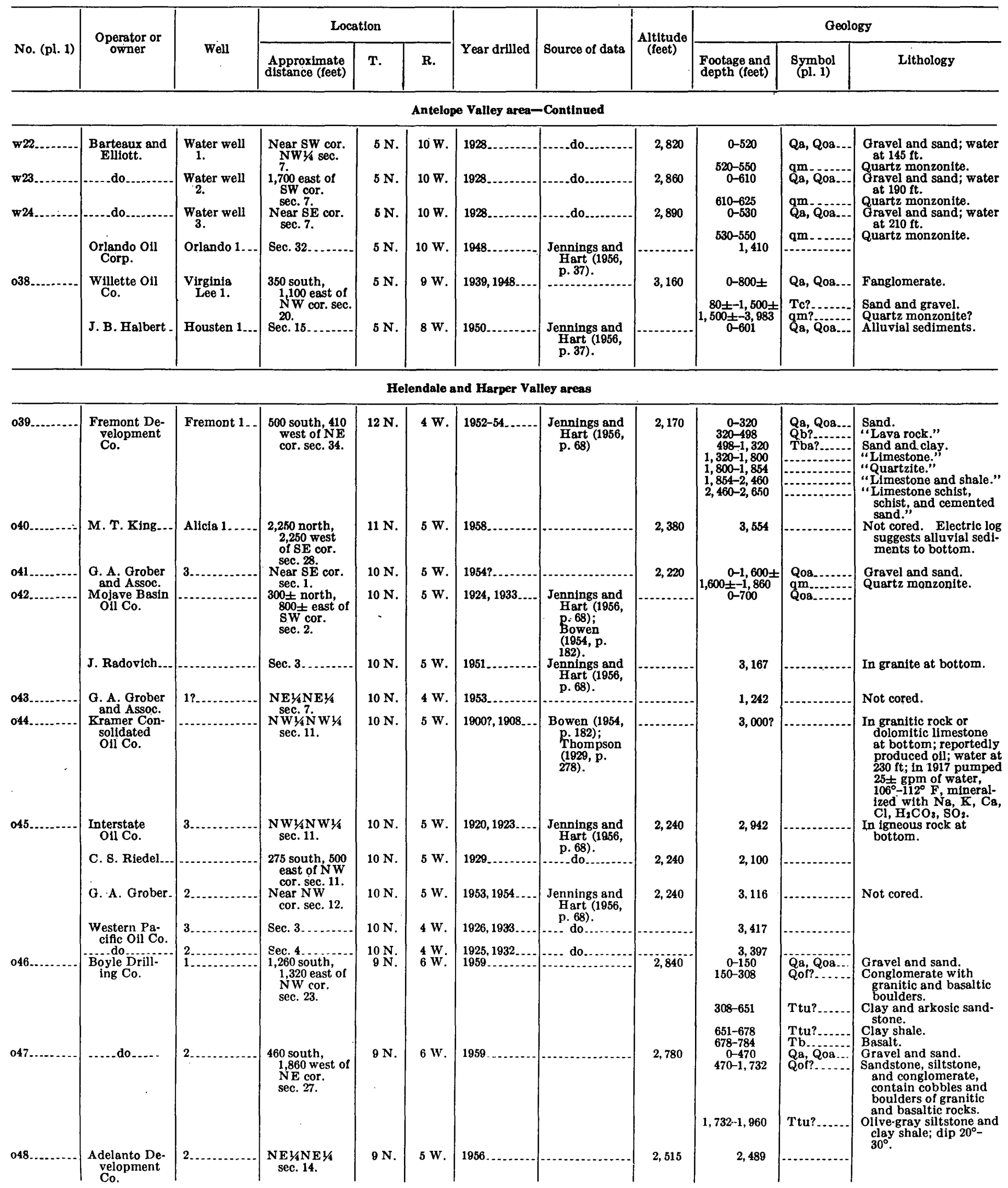


TABLES

TABLE 4.-Exploratory test wells drilled for oil and gas, and geologically significant water wells, in western Mojave Desert region-Con.

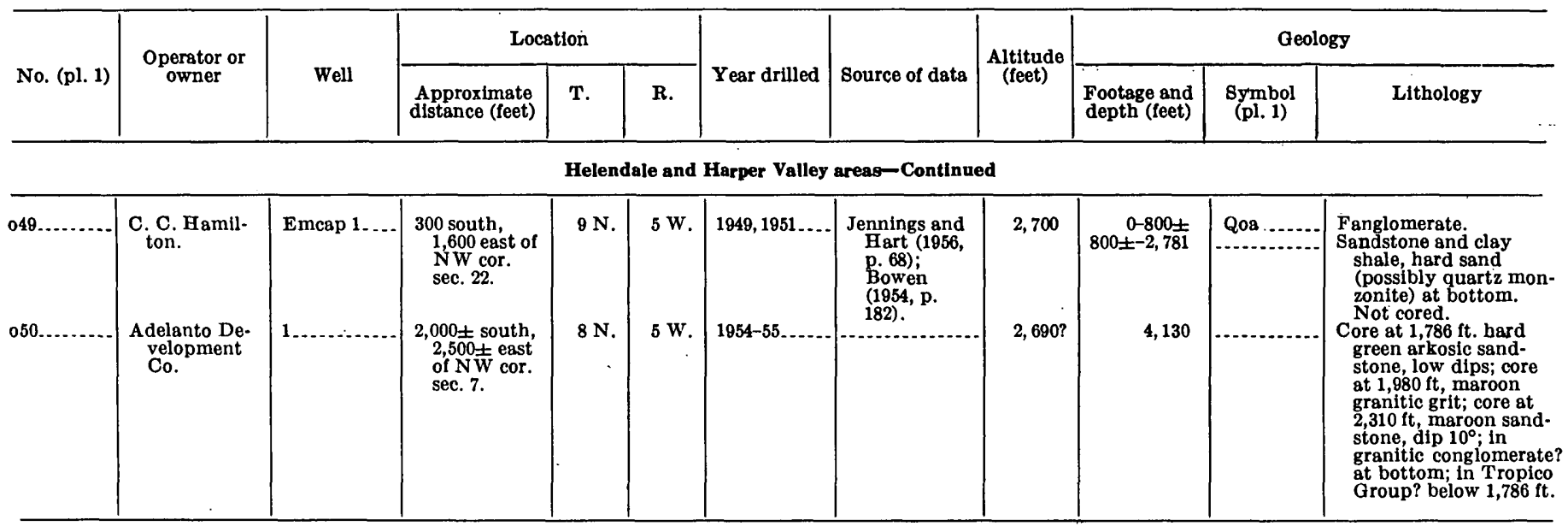

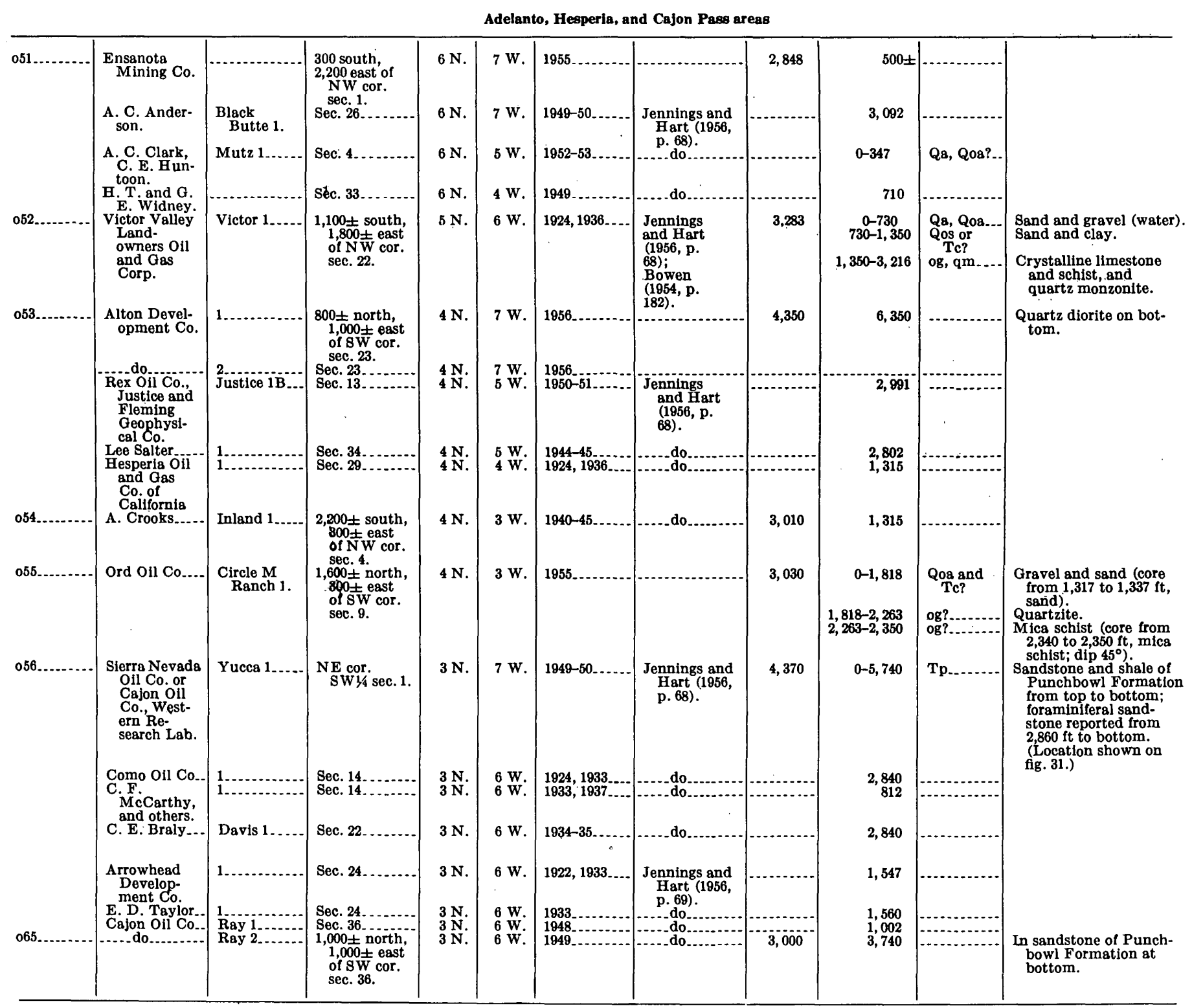

